
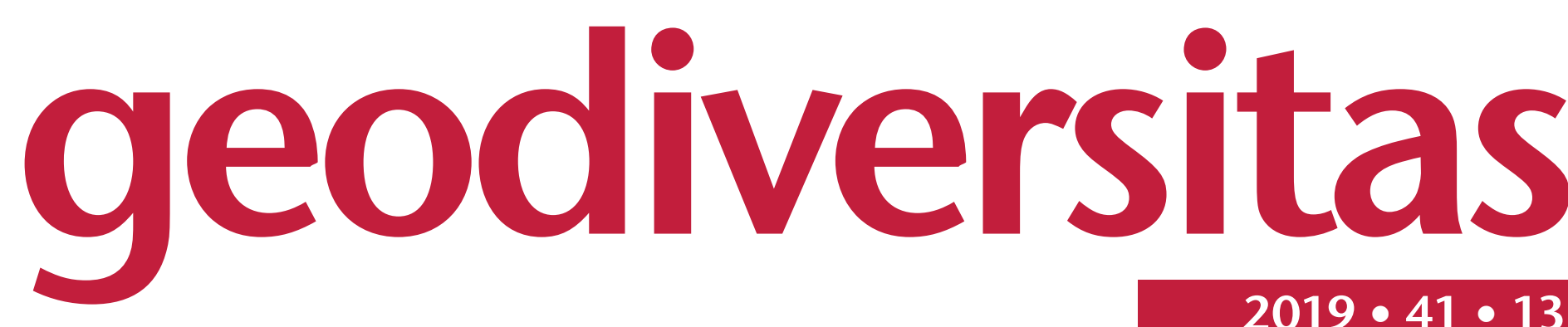
$2019 \cdot 41 \cdot 13$

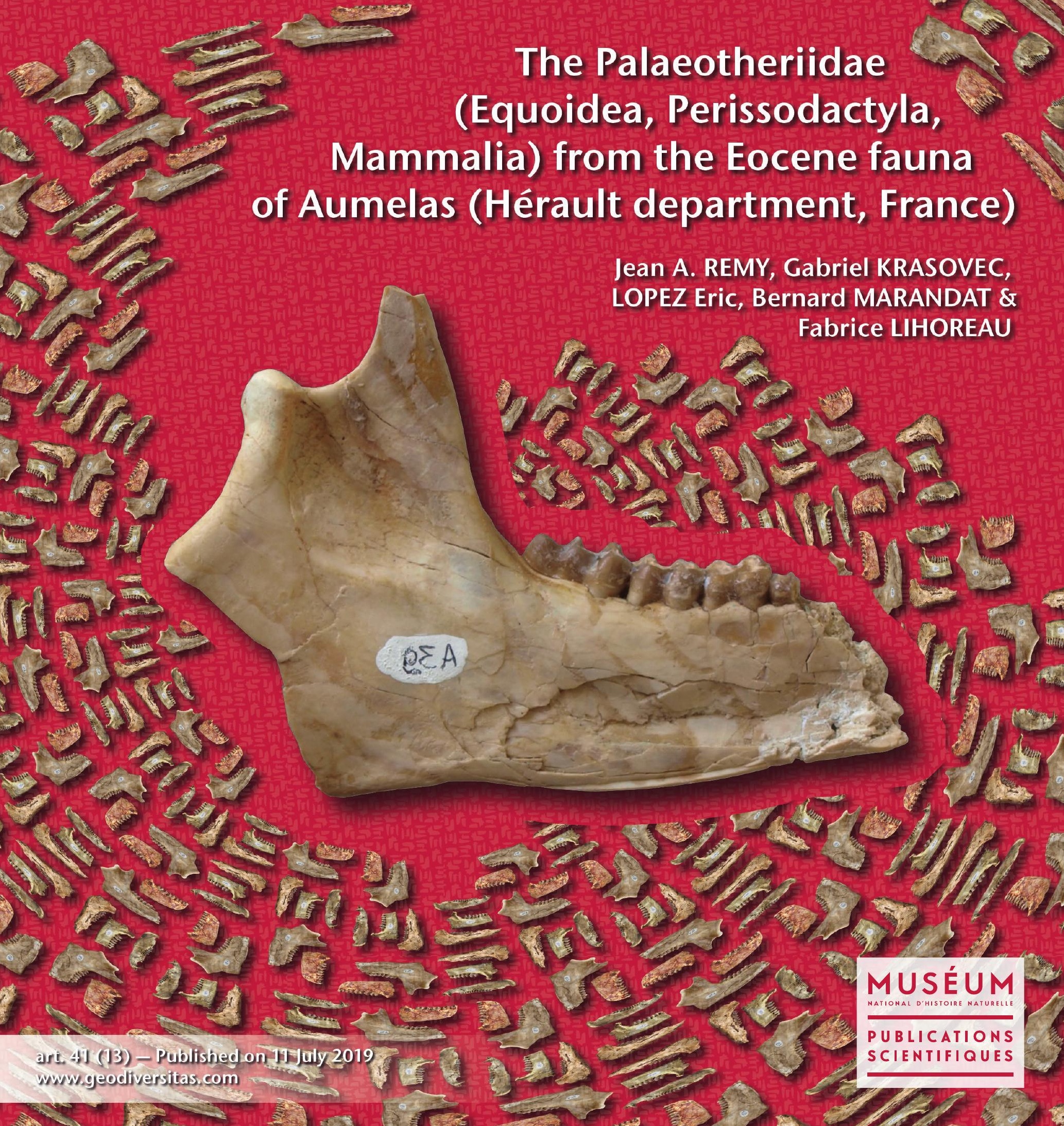


DiRECTEUR DE LA PUBLICATION: Bruno David,

Président du Muséum national d'Histoire naturelle

RÉdACTEUR EN CHEF / EDITOR-IN-CHIEF: Didier Merle

ASSISTANTS DE RÉDACTION / AsSISTANT EDITORS: Emmanuel Côtez (geodiv@mnhn.fr); Anne Mabille

Mise EN PAGE / PAGE LAYOUT: Emmanuel Côtez

COMITÉ SCIENTIFIQUE / SCIENTIFIC BOARD:

Christine Argot (MNHN, Paris)

Beatrix Azanza (Museo Nacional de Ciencias Naturales, Madrid)

Raymond L. Bernor (Howard University, Washington DC)

Alain Blieck (chercheur CNRS retraité, Haubourdin)

Henning Blom (Uppsala University)

Jean Broutin (UPMC, Paris)

Gaël Clément (MNHN, Paris)

Ted Daeschler (Academy of Natural Sciences, Philadelphie)

Bruno David (MNHN, Paris)

Gregory D. Edgecombe (The Natural History Museum, Londres)

Ursula Göhlich (Natural History Museum Vienna)

Jin Meng (American Museum of Natural History, New York)

Brigitte Meyer-Berthaud (CIRAD, Montpellier)

Zhu Min (Chinese Academy of Sciences, Pékin)

Isabelle Rouget (UPMC, Paris)

Sevket Sen (MNHN, Paris)

Stanislav Štamberg (Museum of Eastern Bohemia, Hradec Králové)

Paul Taylor (The Natural History Museum, Londres)

COUVERTURE / COVER:

Made from the figures of the article.

Geodiversitas est indexé dans / Geodiversitas is indexed in:

- Science Citation Index Expanded (SciSearch ${ }^{\circledR}$ )

- ISI Alerting Services ${ }^{\circledR}$

- Current Contents ${ }^{\circledR}$ / Physical, Chemical, and Earth Sciences ${ }^{\circledR}$

- Scopus ${ }^{\circledR}$

Geodiversitas est distribué en version électronique par / Geodiversitas is distributed electronically by:

- BioOne ${ }^{\circledR}$ (http://www.bioone.org)

Les articles ainsi que les nouveautés nomenclaturales publiés dans Geodiversitas sont référencés par / Articles and nomenclatural novelties published in Geodiversitas are referenced by:

- ZooBank ${ }^{\circledR}$ (http://zoobank.org)

Geodiversitas est une revue en flux continu publiée par les Publications scientifiques du Muséum, Paris Geodiversitas is a fast track journal published by the Museum Science Press, Paris

Les Publications scientifiques du Muséum publient aussi / The Museum Science Press also publish:

Adansonia, Zoosystema, Anthropozoologica, European Journal of Taxonomy, Naturae, Cryptogamie sous-sections Algologie, Bryologie, Mycologie.

Diffusion - Publications scientifiques Muséum national d'Histoire naturelle

CP $41-57$ rue Cuvier F-75231 Paris cedex 05 (France)

Tél. : 33 (0)1407948 05 / Fax: 33 (0)14079 3840

diff.pub@mnhn.fr / http://sciencepress.mnhn.fr

(C) Publications scientifiques du Muséum national d'Histoire naturelle, Paris, 2019

ISSN (imprimé / print): 1280-9659/ ISSN (électronique / electronic): 1638-9395 


\title{
The Palaeotheriidae (Equoidea, Perissodactyla, Mammalia) from the Eocene fauna of Aumelas (Hérault department, France)
}

\author{
Jean A. REMY \\ Gabriel KRASOVEC \\ ISEM, Univ. Montpellier, \\ CNRS, IRD, EPHE, CIRAD, INRAP, \\ place Eugène Bataillon, F-34095 Montpellier (France) \\ jean.a.remy@free.fr (corresponding author) \\ Éric LOPEZ \\ 2 rue Pasteur, F-21200 Beaune (France) \\ Bernard MARANDAT \\ Fabrice LIHOREAU \\ ISEM, Univ. Montpellier, \\ CNRS, IRD, EPHE, CIRAD, INRAP, \\ place Eugène Bataillon, F-34095 Montpellier (France)
}

Submitted on 29 July 2018 | accepted on 27 February 2019 | published on 11 July 2019

Remy J. A., Krasovec G., Lopez E., Marandat B. \& Lihoreau F. 2019. - The Palaeotheriidae (Equoidea, Perissodactyla, Mammalia) from the Eocene fauna of Aumelas (Hérault department, France). Geodiversitas 41 (13): 525-585. https://doi.org/10.5252/geodiversitas2019v41a13. http://geodiversitas.com/41/13

\section{ABSTRACT}

The rich vertebrate fauna of Aumelas has from decades been the subject of several partial publications, which led to assign it an age close to the MP 13 reference level in the biochronological scale of Western European mammals; but it is still partially unpublished and this paper is part of a general review of the fauna. With regard to equoid perissodactyls, five taxa have been distinguished, to be assigned to the "Pachynolophinae" to the exclusion of any Palaeotheriinae. Two leading species appear in this ensemble: Propalaeotherium sudrei Remy, Krasovec \& Marandat, 2016 and Pachynolophus

KEY WORDS

Pachynolophinae, Pachynolophus,

Propalaeotherium Lophiotherium phylogeny,

biochronology, new species. ruscassierensis $\mathrm{n}$. $\mathrm{sp}$. The three other taxa are less documented, which prevents a specific determination, Pachynolophus sp., Propalaeotherium cf. gaudryi (Lemoine, 1878) and Lophiotherium sp. All of these species display relatively archaic features as highlighted by a cladistic analysis. Such a conclusion challenges the hitherto prevailing consensus on the dating of the fauna, in the sense of an older biochronological age. This discrepancy will be discussed in a subsequent synthetic work, in conjunction with specialists of all mammal and reptile orders represented in the locality. 
MOTS CLÉS

Pachynolophinae, Pachynolophus,

Propalaeotherium,

Lophiotherium

phylogénie,

biochronologie,

espèce nouvelle.

\begin{abstract}
RÉSUMÉ
Les Palaeotheriidae (Equoidea, Perissodactyla, Mammalia) de la faune éocène d'Aumelas (Hérault, France). La riche faune de vertébrés d'Aumelas a été le sujet depuis plusieurs décennies de diverses publications partielles qui avaient conduit à lui assigner un âge voisin du niveau-repère MP 13 dans l'échelle biochronologique de mammifères d'Europe de l'Ouest. Mais elle reste encore partiellement inédite et cet article fait partie d'une révision générale de la faune. En ce qui concerne les périssodactyles équoïdes, cinq taxons ont été distingués, que l'on attribue à des "Pachynolophinae" à l'exclusion de tout Palaeotheriinae. Deux espèces sont prédominantes dans ce groupe: Propalaeotherium sudrei Remy, Krasovec \& Marandat, 2016 et Pachynolophus ruscassierensis n. sp. Les trois autres taxons sont moins bien documentés, ce qui empêche leur détermination spécifique, Pachynolophus sp., Propalaeotherium cf. gaudryi (Lemoine, 1878) et Lophiotherium sp. L'ensemble de ces espèces présente des caractéristiques relativement archaïques, mises en lumière grâce à une analyse cladistique. Une telle conclusion remet en question le consensus jusqu'ici en vigueur sur la datation de la faune, dans le sens d'un âge biochronologique plus ancien. Cette discordance sera analysée dans un travail synthétique ultérieur, en conjonction avec les spécialistes des différents ordres de mammifères et de reptiles représentés dans la localité.
\end{abstract}

\section{INTRODUCTION}

The Aumelas locality situated about $20 \mathrm{~km}$ west of Montpellier (Hérault, France) was discovered in 1961 by M. Gabineaud and exploited since by the Laboratory of Palaeontology of the University of Montpellier. It consists of lacustrine limestones that have yielded the gastropods Limnaea michelini Deshayes, 1863 and Biomphalaria pseudoammonius (Schlotheim, 1820). It has been therefore attributed to the Lutetian stage (Hartenberger 1963; Sudre 1980; Crochet et al. 1988). Many vertebrate remains have been extracted by acid dissolution of the carbonated matrix. A preliminary list of the resulting fauna was proposed by Sudre (1980) but is still left incomplete. This fauna brings together crocodilians (Martin 2016), chelonians and mammals. Among the latter, it is possible to recognize marsupials, bats, rodents, lipothyphlan insectivores, primates, creodonts, artiodactyls and perissodactyls (Sudre 1978, 1980, 1988; Crochet 1979; Godinot 1988; Escarguel 1999; Maitre et al. 2008; Maitre 2014). The biochronological indications provided by diverse faunal elements had led authors to propose that this rich fauna could be close to the reference level MP 13 (Geiseltal Obere Mittelkhole, Late Lutetian; Schmidt-Kittler 1987). However, a large amount of the collected material still needs to be published. After the recent description of a new species of Propalaeotherium (Remy et al. 2016), we present a completed revision of the Equoidea of this locality, that we all refer to Palaeotheriidae. This material was specifically attributed and its phylogenic status established through a cladistic analysis. The description of this original material is a key to recover the biochronological assignment of the Aumelas horizon.

\section{MATERIAL AND METHODS}

The available sample of vertebrates remains from Aumelas was collected for several decades from 1962 during occasional campaigns of the ISEM (Institut des Sciences de l'Évolution de Montpellier) palaeontology team and was recently enriched by the collection of one of us (EL), an independent researcher who worked on the outcrop before its administrative protection. The collection allows us to study 180 specimens of Equoidea, comprising complete or fragmentary maxillaries and mandibles, and isolated teeth. The deposit is located on maps of the Figure 1.

For dental descriptions, we use the terminology of Hooker (1994) and Remy (2012, 2015), and the measurements of Remy (2015: fig. 2). Poorly preserved teeth are indicated in brackets in the material lists of the systematic part. The metric parameters are hereafter explained. Significance probabilities are established from $t$ test of Student. Concerning occlusal surfaces of upper teeth, which may be regarded as an important parameter of the masticatory function, more sensitive than the PMI ratio (Remy 2012), they conventionally concern the largest outline of the teeth, estimated from pictures, using an image processing software (ImageJ). Several ratios have then been established from these measurements (see Appendix 9).

Biochronological ages are given according to reference levels of the European biochronologic scale of Palaeogene mammals (MP; BiochroM'97). All specimens from Aumelas are held in the UM collections. All specimens are cited AUM XXX in reference to UM-AUM XXX to save space in text, tables and appendices. Measurements are given in millimeters.

\section{ABBREVIATIONS \\ Metric parameters (Fig. 2) \\ D largest diameter of upper molars from parastyle to hypocone; \\ d diameter perpendicular to $\mathrm{D}$; \\ $\mathrm{H}_{\text {cing }} \quad$ height of the cingulum/height of the highest cusp $\times$ I 100 \\ $\mathrm{I}_{\mathrm{H}} \quad$ index of hypsodonty of upper cheek teeth (= height of paracone/maximum width of the tooth $\times 100)$; \\ $\mathrm{I}_{\mathrm{H}} \quad$ index of hypsodonty of lower cheek teeth (= height of protoconid / maximum width) (Janis 1988);}



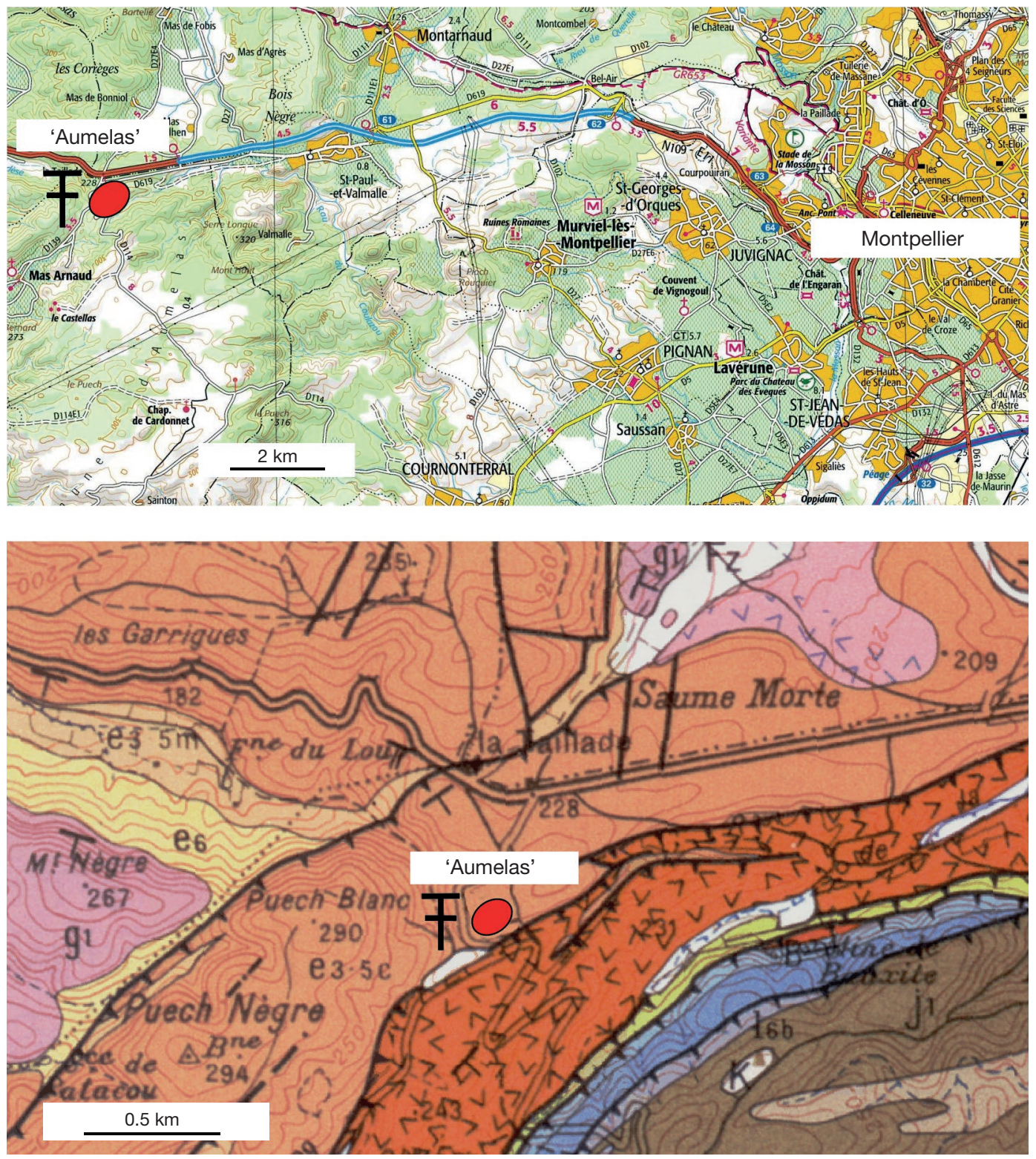

FIG. 1. - Maps positioning the Aumelas locality (Aumelas, Hérault department, France): A, topographic map; B, geological map.

L

W

$\mathrm{W}_{1}$

$\mathrm{W}_{2}$

$\mathrm{W}_{3}$

S

$\mathrm{U}$

DPC

HTMX

LRDJ

MMM ectoloph length (upper cheek teeth) or maximum length (lower cheek teeth);

maximum width (upper teeth);

width of trigonid;

width of talonid;

width of the $\mathrm{M} / 3$ hypoconulid;

surface of upper cheek teeth (measured at the largest outline) in occlusal view;

wear index of tooth from 0 (unworn tooth) to 5 (worn out up to the neck);

post-canine diastema $=$ distance from $\mathrm{C}$ to $\mathrm{P} 2$ (upper or lower) at the bone level;

dorso-ventral height of the maxillary tuberosity at the level of M3/;

length of the tooth row from P2 to M3 (upper or lower);

lever arm of the masseter muscle (= vertical distance referring to the occlusal plane of teeth - from the surface of the condyle to the ventral border of the angular process of the mandible);
MMT

PMI

$\mathrm{S}_{\mathrm{P}} / \mathrm{S}_{\mathrm{M}}$

$\mathrm{S}_{\mathrm{P} 4} / \mathrm{S}_{\mathrm{M}}$

$\%$ DPC

\section{Institutional abbreviations}

AMNH American Museum of Natural History, New York;

FSL Université Claude Bernard, Lyon;

FPO Université de Poitiers, laboratoire Palevoprim, Poitiers;

GMH Geiseltal Museum, Halle;

HLMD Hessisches Landesmuseum, Darmstadt;

ICP Instituto Catalán de Paleontología Miquel Crusafont,

$\begin{array}{ll} & \text { Barcelona; } \\ \text { MBO } & \text { Muséum d'Histoire naturelle, Bordeaux; }\end{array}$ 

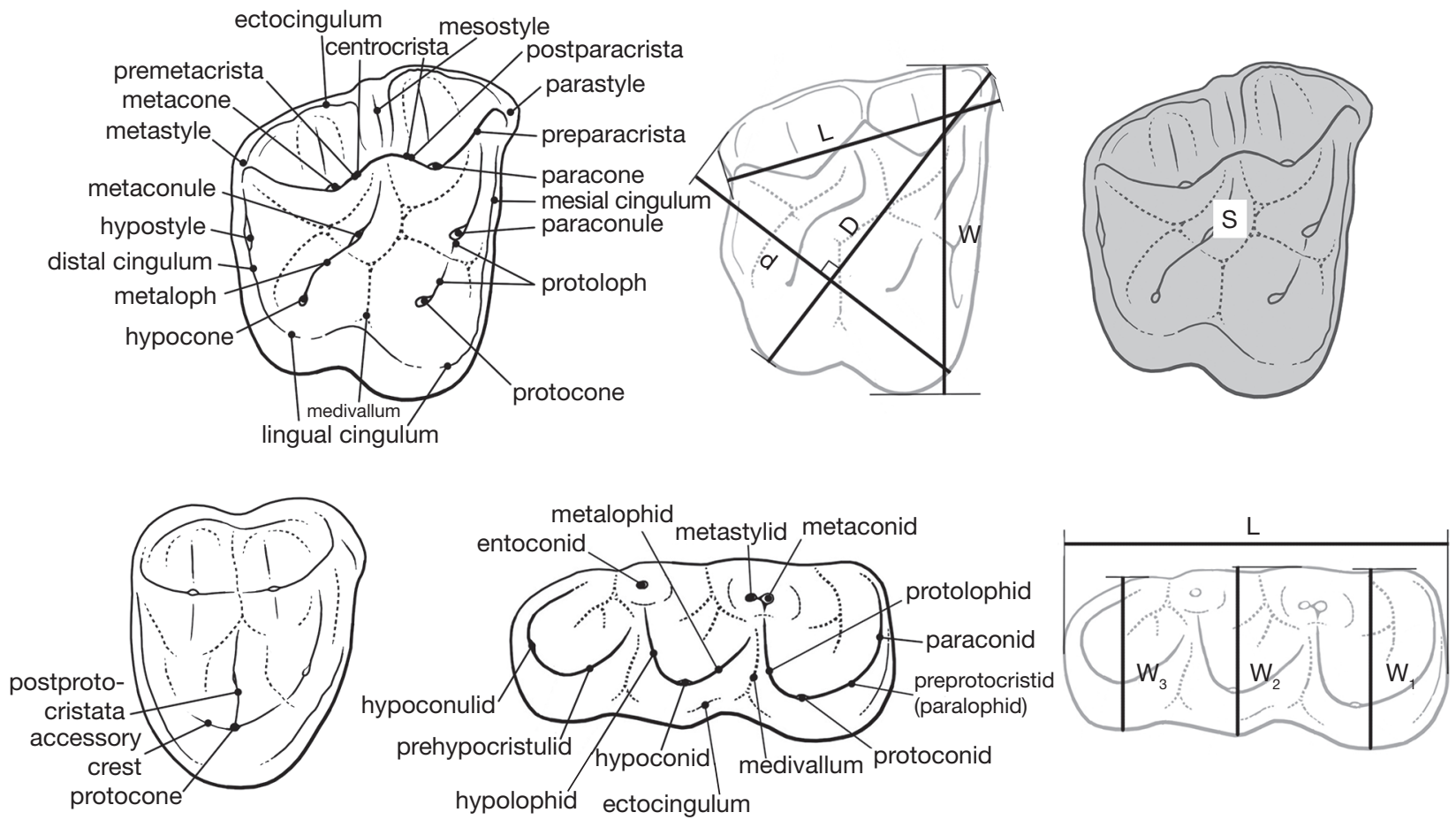

FIG. 2. - Teeth nomenclature and measurements. The surface $S$ of upper cheek teeth is the area measured at the largest outline in occlusal view.

MNHN Muséum national d'Histoire naturelle, Paris;

MHNT Muséum d'Histoire naturelle, Toulouse;

NHML Natural History Museum, London;

NMB Naturhistorisches Museum, Basel;

UCMP University of California Museum of Paleontology, Berkeley;

UM Université de Montpellier, Institut des Sciences de l'Évolution.

\section{SYSTEMATIC PALAEONTOLOGY}

Order PERISSODACTYLA Owen, 1848

Suborder HIPPOMORPHA Wood, 1937

Superfamily EQUOIDEA Hay, 1902

Family PALAEOTHERIIDAe Bonaparte, 1850 (s.l.)

Subfamily "PaChynolophinaE" Pavlow, 1888

\section{REMARK}

Several recent cladistic analyzes conclude that the subfamily Pachynolophinae must be considered as para- or even polyphyletic (Hooker 1994; Froehlich 1999. Danilo et al. 2013). The concept is nevertheless used here, for convenience, in order to gather all genera of Equoidea from the European Paleogene not included in the Palaeotheriinae (Remy 2015: 43).

\section{Genus Propalaeotherium Gervais, 1849}

EMENDED DIAGNOSIS OF GENUS (according to Remy et al. 2016). Small to large equoids with estimated skull length from 120 to about 250 millimeters; dental formula: 3.1.4.3/3.1.4.3; brachylophodont dentition; upper molars with more or less pronounced mesostyle; upper premolars non-molariform, lacking hypocone; mesostyle on P3-4/ and entoconid on P/3-4 only present in youngest species; lower cheek teeth without paraconid; lower molars with rounded crescentic lobes and twinned prominent rnetaconid; lingual cingula on upper molars, usually weak or absent; lower cheek teeth with more or less developed labial cingula, but with weak or absent lingual cingula; rather short postcanine diastema. Propalaeotherium differs from Eurohippus by a wider skull and narrower ramus with regard to its height.

TyPe SPECIES. - Propalaeotherium isselanum (Cuvier, 1824).

INCLUdED SPECIES. - Pr. argentonicum Gervais, 1849, Pr. gaudryi (Lemoine, 1878) (synonym of Propachynolophus gaudryi Lemoine, 1878; see Remy 2017), Pr. hassiacum Haupt, 1925, Pr. helveticum Savage, Russell, Louis, 1965, Pr. voigti Matthes, 1977.

\section{Propalaeotherium sudrei}

Remy, Krasovec \& Marandat, 2016

(Figs 3; 5)

Propalaeotherium sudrei Remy, Krasovec \& Marandat, 2016: 3.

Propalaeotherium sp. (cf. parvulum?) - Hartenberger 1963: 321.

Propalaeotherium sp. - Remy 1976: 19, 20.

Propalaeotherium sp. - Sudre 1980: 199, 200.

Holotype. - AUM 181, a palate bearing right (P1/)-P2/-M3/ and left (P4/-M1/)-M2-3 (Fig. 3A).

Already pUblished Material. - AUM 173, left M1/; AUM 174, left maxillary fragment with (P4/)-M1/; AUM 175, right maxillary fragment with P4/-M3/; AUM 201, left maxillary fragment with M1-2/; AUM 202, left M2/-(M3/); AUM 
TABLE 1. - Synthetic table of measurements (in mm) of cheek teeth of Propalaeotherium sudrei Remy, Krasovec \& Marandat, 2016 from Aumelas. Abbreviations: L, length of ectoloph (upper teeth) or maximal length (lower); W, maximum width; W1, trigonid width; W2, talonid width; W3, hypoconulid width (M/3); D, maximum diameter from parastyle to hypocone; d, diameter perpendicular to D (see Fig. 2). For individual data, see Appendix 3 . No complete lower series available; therefore, estimates were made from tooth length averages of the whole sample.

Propalaeotherium sudrei

\begin{tabular}{|c|c|c|c|c|c|c|c|c|c|c|c|c|c|c|c|c|c|c|}
\hline & \multicolumn{2}{|c|}{ P2/ } & \multicolumn{2}{|c|}{ P3/ } & \multicolumn{2}{|c|}{ P4/ } & \multicolumn{4}{|c|}{ M1/ } & \multicolumn{4}{|c|}{ M2/ } & \multicolumn{4}{|c|}{ M3/ } \\
\hline & $\mathbf{L}$ & $\mathbf{W}$ & $\mathbf{L}$ & $\mathbf{W}$ & $\mathbf{L}$ & W & $\mathbf{L}$ & $\mathbf{W}$ & D & d & $\mathbf{L}$ & $\mathbf{W}$ & D & d & $\mathbf{L}$ & W & D & d \\
\hline $\mathrm{N}$ & 1 & 1 & 2 & 2 & 5 & 5 & 6 & 6 & 6 & 6 & 4 & 4 & 4 & 4 & 3 & 2 & 3 & 3 \\
\hline mean & 7.1 & 5.9 & 8.1 & 9.0 & 8.6 & 11.0 & 10.4 & 12.3 & 13.3 & 12.4 & 11.9 & 14.0 & 14.9 & 13.9 & 12.0 & 13.7 & 15.0 & 14.0 \\
\hline $\begin{array}{l}\text { variation } \\
\text { range }\end{array}$ & - & - & $\begin{array}{l}8.0- \\
8.1\end{array}$ & $\begin{array}{l}8.3- \\
9.7\end{array}$ & $\begin{array}{l}8.2- \\
9.4\end{array}$ & $\begin{array}{l}10.1- \\
11.4\end{array}$ & $\begin{array}{l}9.4- \\
11.5\end{array}$ & $\begin{array}{l}11.1- \\
12.9\end{array}$ & $\begin{array}{l}11.6- \\
14.3\end{array}$ & $\begin{array}{l}11.1- \\
13.3\end{array}$ & $\begin{array}{l}11.1- \\
12.9\end{array}$ & $\begin{array}{l}13.7- \\
14.6\end{array}$ & $\begin{array}{l}14.0- \\
15.8\end{array}$ & $\begin{array}{l}13.1- \\
14.8\end{array}$ & $\begin{array}{l}11.5- \\
12.5\end{array}$ & $\begin{array}{l}13.7- \\
13.7\end{array}$ & $\begin{array}{c}14.0- \\
15.5\end{array}$ & $\begin{array}{l}13.6- \\
14.4\end{array}$ \\
\hline $\begin{array}{l}\text { standard } \\
\text { deviation }\end{array}$ & - & - & - & - & 0.471 & 0.532 & 0.842 & 0.660 & 1.029 & 0.763 & 0.772 & 0.403 & 0.957 & 0.714 & 0.503 & - & 0.823 & 0.400 \\
\hline $\begin{array}{l}\text { coeff. of } \\
\text { variation }\end{array}$ & - & - & - & - & 5.5 & 4.8 & 8.1 & 5.4 & 7.8 & 6.1 & 6.5 & 2.9 & 6.4 & 5.1 & 4.2 & - & 5.5 & 2.9 \\
\hline
\end{tabular}

\begin{tabular}{|c|c|c|c|c|c|c|c|c|c|}
\hline & \multicolumn{4}{|c|}{ DP4/ } & upper series & \multirow{2}{*}{$\frac{\text { LP2-M3 }}{1}$} & \multirow{2}{*}{$\begin{array}{c}\text { LP2-P4 } \\
1\end{array}$} & \multirow{2}{*}{$\begin{array}{c}\text { LM1-M3 } \\
2\end{array}$} & \multirow{2}{*}{$\begin{array}{c}\text { PMI } \\
1\end{array}$} \\
\hline & $\mathbf{L}$ & $\mathbf{W}$ & D & d & $\mathrm{N}$ & & & & \\
\hline $\mathrm{N}$ & 1 & 1 & 1 & 1 & mean & 54.0 & 22.0 & 31.3 & 69.8 \\
\hline mean & 9.5 & 10.3 & 11.7 & 10.1 & variation range & - & - & $31.0-31.5$ & - \\
\hline
\end{tabular}

\begin{tabular}{|c|c|c|c|c|c|c|c|c|c|c|c|c|c|c|c|c|c|c|c|}
\hline & \multicolumn{3}{|c|}{$\mathrm{P} / 2$} & \multicolumn{3}{|c|}{$\mathrm{P} / 3$} & \multicolumn{3}{|c|}{$\mathrm{P} / 4$} & \multicolumn{3}{|c|}{ M/1 } & \multicolumn{3}{|c|}{$M / 2$} & \multicolumn{4}{|c|}{$M / 3$} \\
\hline & $\mathbf{L}$ & W1 & W2 & $\mathbf{L}$ & W1 & W2 & $\mathbf{L}$ & W1 & W2 & $\mathbf{L}$ & W1 & W2 & $\mathbf{L}$ & W1 & W2 & $\mathbf{L}$ & W1 & W2 & W3 \\
\hline $\mathrm{N}$ & 2 & 3 & 3 & 4 & 4 & 4 & 10 & 10 & 10 & 6 & 6 & 6 & 11 & 11 & 11 & 16 & 19 & 19 & 16 \\
\hline mean & 7.0 & 3.7 & 3.8 & 7.9 & 4.6 & 5.2 & 9.0 & 6.2 & 6.3 & 10.1 & 7.4 & 7.3 & 11.5 & 8.1 & 7.9 & 16.1 & 8.3 & 7.4 & 5.6 \\
\hline $\begin{array}{c}\text { variation } \\
\text { range }\end{array}$ & $\begin{array}{l}7.0- \\
7.0\end{array}$ & $\begin{array}{l}3.7- \\
3.7\end{array}$ & $\begin{array}{l}3.7- \\
4.0\end{array}$ & $\begin{array}{l}7.4- \\
8.2\end{array}$ & $\begin{array}{c}4.7- \\
5.0\end{array}$ & $\begin{array}{l}5.0- \\
5.5\end{array}$ & $\begin{array}{c}8.5- \\
9.7\end{array}$ & $\begin{array}{c}5.7- \\
6.9\end{array}$ & $\begin{array}{c}5.9- \\
6.9\end{array}$ & $\begin{array}{l}9.7- \\
10.6\end{array}$ & $\begin{array}{l}7.0- \\
7.8\end{array}$ & $\begin{array}{l}6.9- \\
7.7\end{array}$ & $\begin{array}{l}10.1- \\
12.2\end{array}$ & $\begin{array}{c}6.9- \\
8.7\end{array}$ & $\begin{array}{l}7.4- \\
8.5\end{array}$ & $\begin{array}{c}15.3- \\
17.8\end{array}$ & $\begin{array}{l}7.3- \\
9.0\end{array}$ & $\begin{array}{c}6.6- \\
8.4\end{array}$ & $\begin{array}{c}5.1- \\
6.3\end{array}$ \\
\hline $\begin{array}{l}\text { standard } \\
\text { deviation }\end{array}$ & & 0.058 & 0.153 & 0.359 & 0.377 & 0.320 & 0.490 & 0.398 & 30.430 & 0.403 & 0.266 & 0.333 & 0.594 & 0.477 & 0.342 & 0.943 & 0.530 & 0.550 & 0.371 \\
\hline $\begin{array}{l}\text { coeff. of } \\
\text { variation }\end{array}$ & & 1.5 & 4.0 & 4.6 & 8.2 & 6.1 & 5.5 & 6.5 & 6.9 & 4.0 & 3.6 & 4.6 & 5.2 & 5.9 & 4.3 & 5.9 & 6.4 & 7.4 & 6.6 \\
\hline
\end{tabular}

\begin{tabular}{lccccccc}
\hline & \multicolumn{3}{c}{ DP/3 } & & & \multicolumn{3}{c}{ DP/4 } \\
\cline { 2 - 4 } \cline { 5 - 7 } & $\mathbf{L}$ & W1 & W2 & & L & W1 & W2 \\
\hline $\mathrm{N}$ & - & - & 1 & & 1 & 1 & 1 \\
mean & - & - & 5.4 & 9.0 & 6.2 & 6.3 \\
\hline
\end{tabular}

\begin{tabular}{lcccc}
\hline lower series & LP2-M3 & LP2-P4 & LM1-M3 & PMI \\
\hline from means & 61.5 & 23.8 & 37.7 & 63.2 \\
\hline
\end{tabular}

207, right P3/; AUM 221, left M1/; AUM 223, right DP4/; AUM 44, AUM 45, left M/1-2; AUM 64, left (M/3); AUM 113, left M/3; AUM 163, left M/2-(M/3); AUM 165, right M/2-(M/3); AUM 171, left (P/2)-P/3-4; AUM 179, left mandible with P/4M/3; AUM 180, left mandibular fragment with (M/3); AUM 182, left mandibular fragment with $(\mathrm{D} / 3)-\mathrm{D} / 4-\mathrm{M} / 1([\mathrm{P} / 4]-\mathrm{M} / 1-\mathrm{M} / 2$ in Hartenberger 1963); AUM 183, left M/2- M/3; AUM 203, right $\mathrm{M} / 3$; AUM 205, right mandible with angular area, ascending branch and M/3; AUM 208, left mandible with (alv.P/2-alv. P/3)-P/4-M/1-(M/2)-M/3; AUM 212, left M/3; AUM 215, right $\mathrm{M} / 3$; AUM 218, right $\mathrm{M} / 3$; AUM 219, right $\mathrm{M} / 2$; AUM 220, right M/2; AUM 228, right M/3; AUM 310, left mandibular fragment with $\mathrm{P} / 4, \mathrm{M} / 2-(\mathrm{M} / 3)$; AUM 331, right mandible with $\mathrm{P} / 2-\mathrm{M} / 1$ ( $\mathrm{P} / 1-\mathrm{P} / 4$ in Remy et al. 2016).

EXCLUDED MATERIAL. - AUM 206, right mandible with (alv.P/1alv.P/2)-P/3-M/3 (now assigned to Propalaeotherium cf. gaudryi); AUM 227, left M/3 (now assigned to Pachynolophus sp.).

NeW MATERIAL. - AUM 1597, right P4/; AUM 1647, right P4/. AUM 71, right mandible fragment with $\mathrm{P} / 2-\mathrm{P} / 3$ and alveoli of $\mathrm{P} / 1$; AUM 166, right mandible fragment with (alv.P/1-alv.P/2)$\mathrm{P} / 3-\mathrm{M} / 1-(\mathrm{M} / 2)$; AUM 204, right (M/3); AUM 1572, right $\mathrm{M} / 3$; AUM 1574, right P/4; AUM 1609, AUM 1610, AUM 1611 right P/4; AUM 1613, left M/3; AUM 1614, right M/3; AUM 1650, AUM 1651, left M/2; AUM 1655, right M/3; AUM 1656, left M/3.
MATERIAL FROM ANOTHER LOCALITY. - Saint-Martin de Londres (SMF) UM-SMF 63, left P4/-M3/; UM-SMF 64, right DP4/ (Crochet et al. 1988: fig. 18-19).

EMENDED DIAGNOSIS (ADAPTED FROM Remy et al. 2016). - Small species of Propalaeotherium, average estimated weight about $25 \mathrm{~kg}$. Dentition not very brachyodont. Trapezoidal upper molars, distally narrow, with a slightly bulging mesostyle, reaching occlusal surface as a fairly thin crest; deeply notched centrocrista, somewhat elongated conules; M3/ without hypostyle. Premolar series relatively short with low surface area, non molariform, without mesostyle; $\mathrm{P} 4 /$ relatively wide and devoid of hypocone; cingula usually narrow though rather high, with the lingual one often lacking; crescents of lower molars fairly rounded with a well-defined splitting of the metaconid; $\mathrm{P} / 4$ without entoconid.

DiFFERENTIAL DiAgNosis (updated after Remy et al. 2016; Remy 2017). - Smaller dimensions and less brachyodont teeth than most Propalaeotherium species; steady mesostyles on upper molars unlike Pr. gaudryi and thinner enamel. Less bulbous cusps than on the teeth of Pr. hassiacum. Upper premolars lacking mesostyle unlike in Pr. helveticum. Similar in size to Pr. voigti but differing by a more hollow centrocrista on upper molars, less rounded internal cusps and paraconules; relative surface of premolars slightly larger, a more pronounced metaconid splitting on lower check teeth, thinner and lower cingula. 


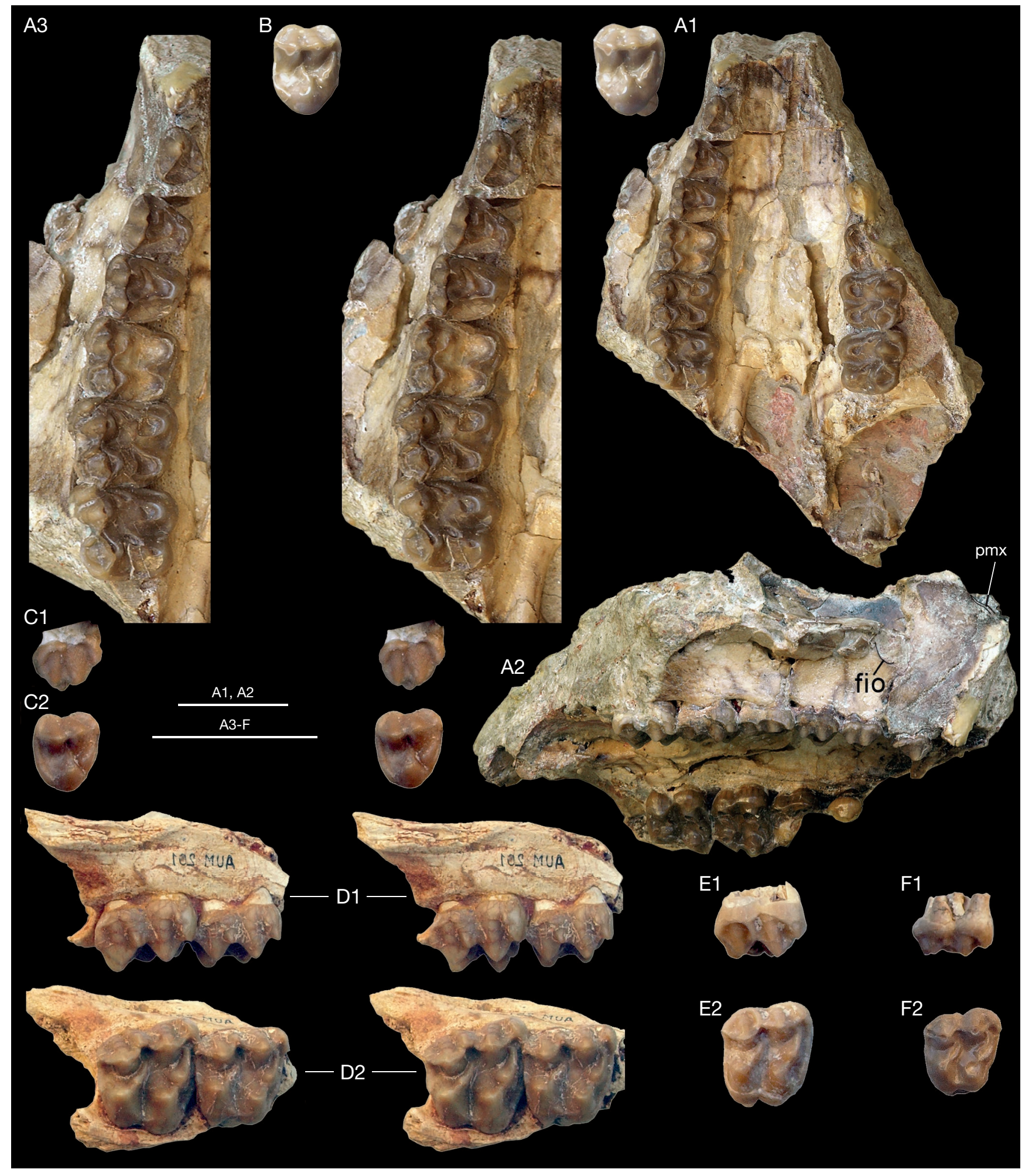

FIG. 3. - Propalaeotherium sudrei Remy, Krasovec \& Marandat, 2016: A, AUM 181, holotype, palate bearing the right (P1/)-P2/-M3/ and left (P4/-M1/)-M2-3/; A1, ventral view; A2, right lateral view; A3, right cheek teeth (stereographs); B, AUM 1647 (stereographs), right P4/, occlusal view; C, AUM 207 (stereographs), right P3/; C1, labial view; C2, occlusal view; D, AUM 201 (stereographs), left maxillary fragment with M1-2/ (reversed); D1, labial view; D2, occlusal view; E, AUM 221, left M1/ (reversed); E1, labial view; E2, occlusal view; F, AUM 223, right DP4/; F1, labial view; F2, occlusal view. Abbreviations: fio, opening of the infra-orbital foramen; pmx, tip of the premaxilla. Scale bars: $2 \mathrm{~cm}$.

It differs from Eurohippus parvulus by its larger size, especially at the molar level; smaller premolar area; less brachyodont teeth; less bul- bous mesostyle of upper molars; wider palate; temporal lever arm of the mandible lower relative to the masseter lever arm. 


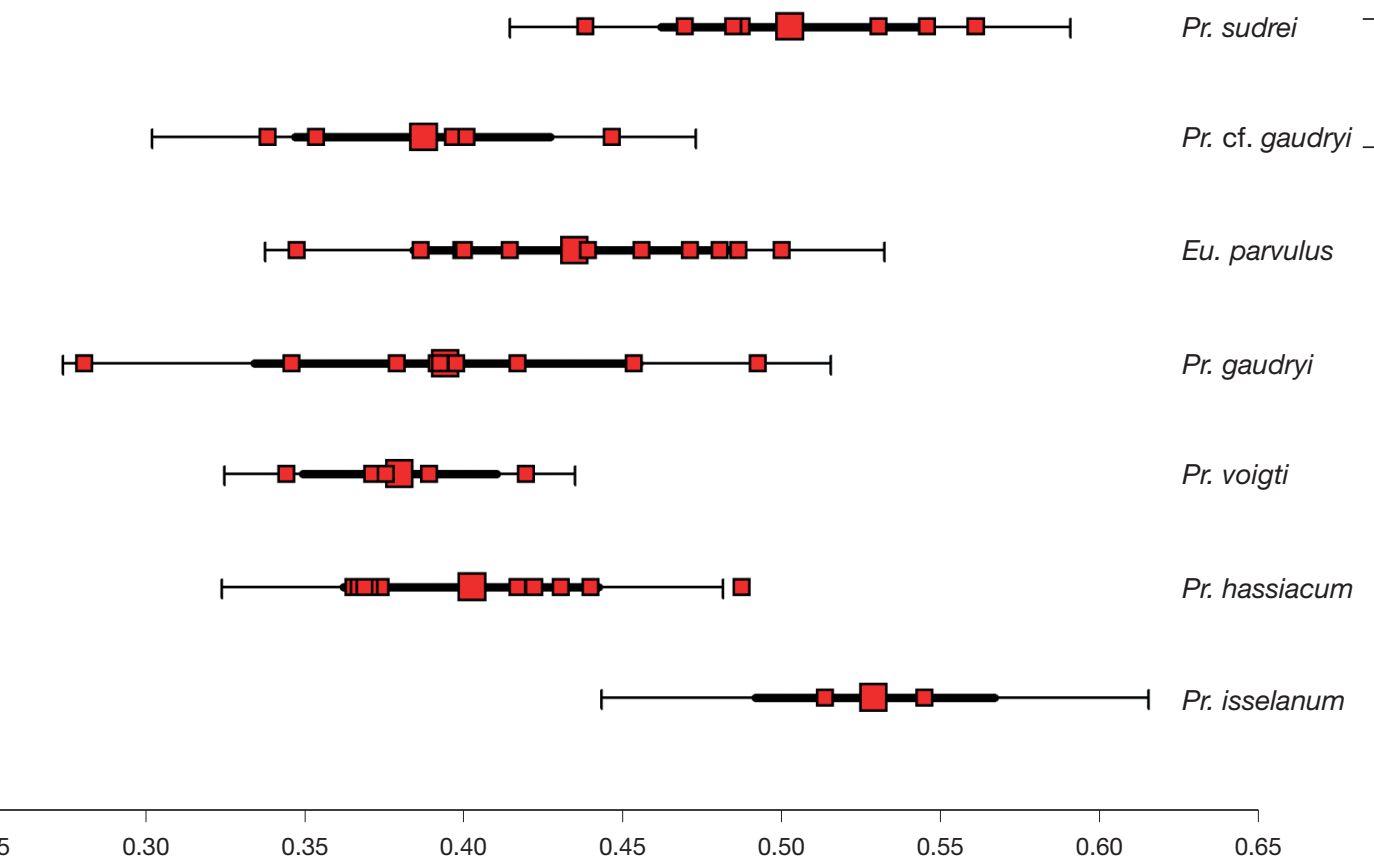

FIG. 4. - Hypsodonty indexes of upper cheek teeth $\left(l_{H}\right)$ for various propalaeotheres. Symbols: large squares, mean; heavy lines, mean $\pm s$; thin lines, mean $\pm 2 s$. Data from Appendices 12 and 13.

\section{OBSERVATIONS}

A detailed description of the material pertaining to Propalaeotherium sudrei was given in the original publication (Remy et al. 2016). It will not be resumed here. But some observations have been made thanks to the new material, which justifies also reproducing updated figures and tables of measures, as well as renewed comments.

First, the size of material assigned to this species, according to equations proposed by Janis (1990) suggests an average body mass of $c .25 \mathrm{~kg}$ (a little less than in Remy 2015, due to additional data) (Appendix 8).

It was observed in Remy et al. (2016) that the hypsodonty indices $\mathrm{I}_{\mathrm{H}}$ were relatively high for a propaleothere. The topic is developed here (Appendix 12) with more comparing items. We can add that at level of lower molars, the $\mathrm{I}_{\mathrm{H}}$, index (Janis 1988), fluctuates from 0.75 to 0.88 with a mean equals to 0.82 (Appendix 15).

Some details were also not highlighted. Thus, on the unworn molars AUM 201 (Fig. 3D) one can observe that the centrocrista is particularly hollow, that the mesostyle is a little larger towards the apex than on other specimens and that the paraconule is notably inflated disto-lingually.

Besides, AUM 1647, whose size matches with that of other $\mathrm{P} 4 /$, displays some peculiarities. The labial cusps are rather close to each other, with a tiny occlusal fold of the ectoloph, as a "pseudomesostyle" (sensu Badiola et al. 2005). The protocone is mesio-distally centred, contrary to AUM 181. The paraconule is elongated, linguo-distally expanded and directed toward the preparacrista. It is separated from the protocone by a very deep groove. The protocone is connected on its anterior side to a sinuous postprotocrista joining the internal side of the metacone, as on the holotype. This metaloph is overhanging a rather wide distal basin, limited by the distal cingulum, which is raised as a small knob at the basis of the protocone. Such a feature, evoking a doubling of the internal cusp, suggests a weak beginning of a molarization process. The P4/ AUM 1597, more worn, apparently shows an identical morphology.

On P/3, a small hypoconid appears generally in medial position. It is more labial on AUM 71, and the metastylid extends to the distal cingulum.

Finally, the AUM 331 mandible teeth were regarded as P/1$\mathrm{P} / 4$ on the 2016 paper, but the extreme wear of the last tooth indicates that it is rather a $\mathrm{P} / 2-\mathrm{M} / 1$ series. Thus, the $\mathrm{P} / 1$ is not known. However, the two broken roots (AUM 166) or alveoli (AUM 71) of this tooth indicate a narrow tooth and confirm the absence of any P/1-P/2 diastema.

Some morphological variability was already noted on specimens of Propalaeotherium sudrei, as usually in propalaeotheres (e.g. Stehlin 1904: 402; Franzen \& Haubold 1986a: 6; Hooker 1986: 345; Franzen 2006: 99; Remy 2015: 81). These last observations are not enough to question, either, the unity of the species.

\section{COMMENTS}

A comparison with the known species of propaleotheres has led to the conclusion that this material represents a distinct taxon. However, the discussion validating this taxon (see discussion in Remy et al. 2016) needs to be updated. Propalaeotherium sudrei should now be compared to Pr. gaudryi, a species recently assigned to the same genus (Remy 2017). The upper molars of Aumelas are only $8 \%$ smaller on average, but the differences are significative ( $\mathrm{t}$ test $\mathrm{p}:<0.1$ to $<0.001$ ) for most parameters (Appendix 16). In surface 


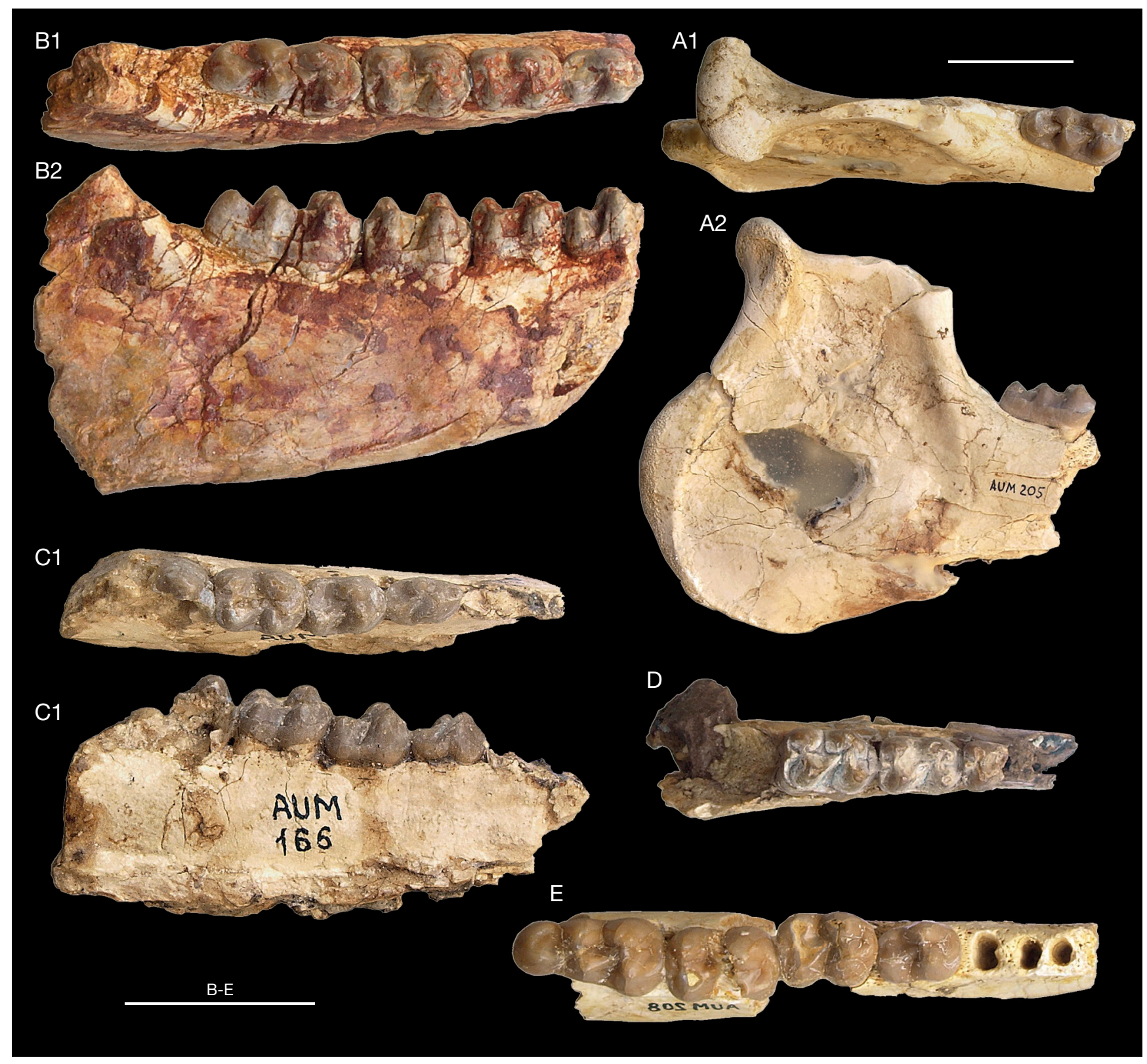

FIG. 5. - Propalaeotherium sudrei Remy, Krasovec \& Marandat, 2016: A, AUM 205, right mandible with M/3; A1, occlusal view; A2, labial view; B, AUM 179, left mandible with P/4-M/3 (reversed); B1, occlusal view; B2, labial view; C, AUM 166, right mandible with P/3-M/1-(M/2); C1, occlusal view; C2, labial view; D, AUM 182, left mandibular fragment with (D/3)-D/4-M/1, (reversed), occlusal view; E, AUM 208, left mandible with (alv.P/2-P/3)-P/4-M/1-(M/2)-M/3 (reversed), occlusal view. Scale bars: 2 cm. (Note that the mandible AUM 206 [Remy et al. 2016: fig.3E-F] is now recorded as Propalaeotherium cf. gaudryi (Lemoine, 1878)).

the differences between upper cheek teeth series average about $-20 \%$ for Pr. sudrei (Appendices 9; 10). Besides, in Pr. sudrei, the area of the premolar series is slightly larger than with Pr. gaudryi, compared to the molar series. Thus, the PMI index is 70 on AUM 181 instead of 61 on FSL 2096 and the ratio $S_{\mathrm{P}} / S_{\mathrm{M}}$ reaches 43 instead of 40 on the same specimens respectively.

Moreover, the enamel of the teeth in Pr. sudrei is apparently thinner. The brachyodonty is clearly less marked: the variation range of the $\mathrm{I}_{\mathrm{H}}$ coefficient is 44 to 56 (with a mean of 50) instead of 35 to 49 (mean of 41) in Pr. gaudryi (Appendices $12 ; 13 ; 14)$. The obliquity of the ectoloph of molars is less marked in Pr. sudrei. A mesostyle is constantly present on upper molars instead of occasional, and more clearly developed. The molar parastyle is less protruding outside. Furthermore, the convexity of the distal edge of $\mathrm{M} 3$ / is usually not so strong and is devoid of hypostyle. The upper premolars, chiefly P2/ and $\mathrm{P} 3 /$, are less transversally elongated. The protocone of $\mathrm{P} 4 /$ is more displaced mesially.

For lower cheek teeth, Pr. sudrei mostly distinguishes by a slightly smaller size despite the high variability of these teeth in Pr. gaudryi ( -5 to $-10 \%$ on molars) (Appendix 17), by a likely less marked brachyodonty ( 0.82 on average instead of $0.75[\mathrm{p}<0.01]$ ) (Appendix 15), and by the generally less shortening of premolar trigonid. In conclusion of all observations, it comes out that Pr. sudrei clearly differs from Pr. gaudryi. 


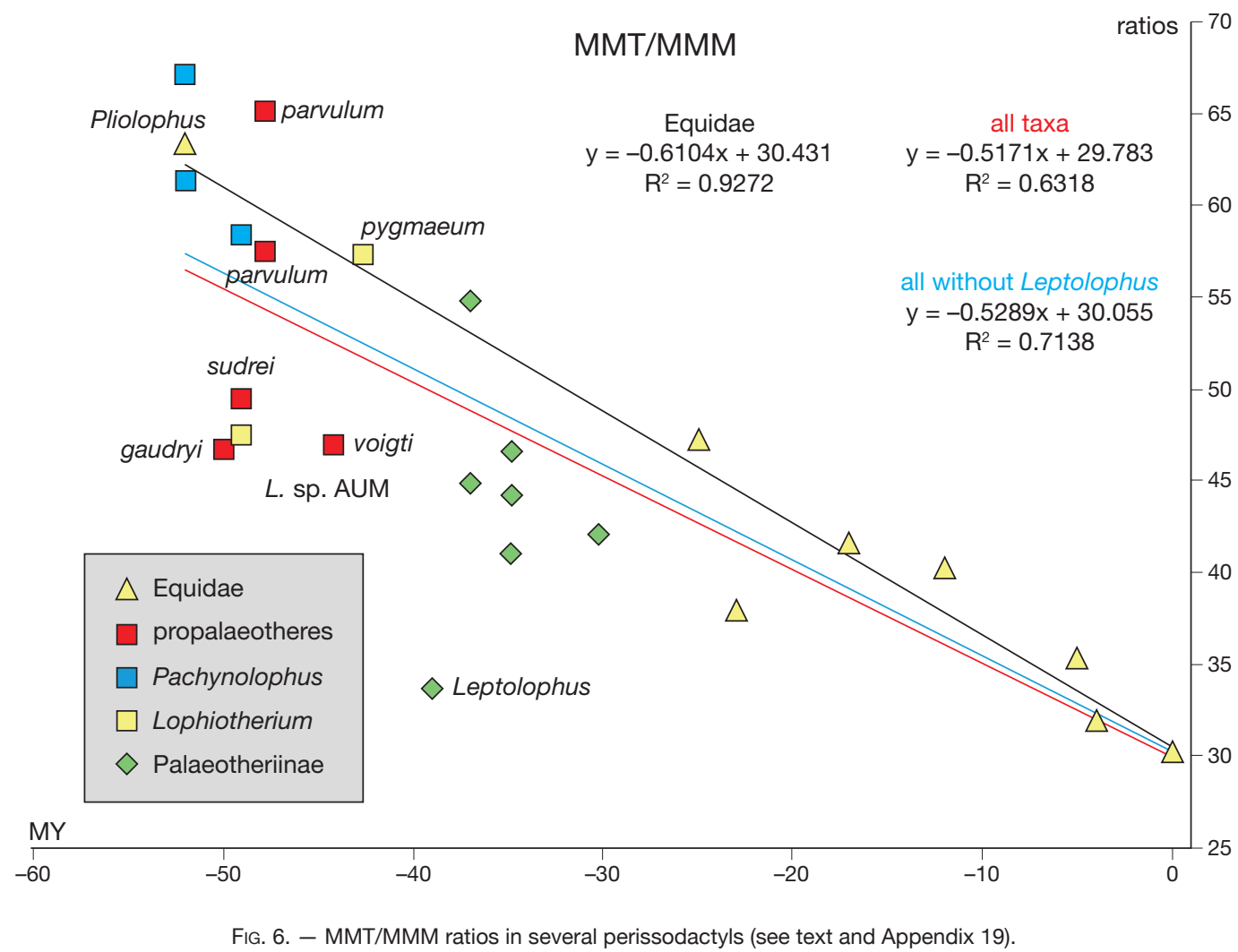

Propalaeotherium sudrei appears smaller than most of other species of the genus. It may only be compared to Pr. voigti from the Geiseltal (Remy et al. 2016), more precisely with the specimens from post-uUk sites (last Unterkohle and Mittelkohle), from which the type specimen of Pr. voigti originates (Appendix 18). lndeed, we have concluded that the specimens of the uUK assigned to Pr. voigti, which are significantly larger (p: $<0.1$ to $<0.001$ ), likely belong to another taxon (Remy et al. 2016).

Besides, it has been shown that specimens from the Pr. voigti type series are distinguished from Pr. sudrei by more brachyodont teeth (Appendix 14; Fig. 4), upper cheek teeth with centrocrista less dug on molars, internal cusps and paraconules more rounded, and protocone-paraconule groove generally deeper. In addition, in Pr. voigti, the cingula are generally higher than those of Pr. sudrei, and the split of the metaconid is less pronounced on lower cheek teeth. These discrepancies led us to conclude that the form of Aumelas cannot belong to Pr. voigti (Remy et al. 2016).

Compared to the monospecific Eurohippus, the other genus of propalaeotheres, upper molars of Propalaeotherium sudrei are significantly larger (Remy et al. 2016 [p: up to <0.001]), but with differences apparently less marked at the level of premolars. Indeed, the surface of the premolar series is smaller relative to that of molars (Appendix 9). Similar differences in size can be observed with linear measures of the lower teeth. Furthermore, upper cheek teeth of Aumelas are distinguished by some other features concerning notably mesostyles and protoloph grooves, and they are less brachyodont (Remy et al. 2016).
We also established, based on the width of the palate, that the skull of Pr. sudrei was probably not as narrow as that of Eurohippus, a discriminating feature of this genus (Remy et al. 2016). At the level of mandible, we considered also the ratio MMT/MMM between the lever arms of the temporal (MMT) and the masseter muscles (MMM). This ratio leads to evaluate the relative importance of the two muscles, which Turnbull (1970) has shown to evolve over time with high correlation coefficients in herbivorous mammals, in the sense of an increasing role of the masseter in the masticatory process. The relative low ratio observed with Pr. sudrei seems more in line with Propalaeotherium than with Eurohippus (Appendix 19; Fig. 6).

Consequently, with regard to these considerations, the material from Aumelas should not be assigned to the genus Eurohippus but to Propalaeotherium of which it points out a new species.

The question arises whether this species is present elsewhere. It was established that it is also found in the St-Martin de Londres locality (Remy et al. 2016), of which the age is not precisely known but has been considered older than the MP 13 level (Crochet et al. 1988).

Concerning the teeth from the fissure fillings of Lissieu formerly attributed to Propalaeotherium parvulum by Stehlin (1904: 440), they can't be assigned to Pr. sudrei as they are generally smaller. Furthermore, their enamel structure is quite different and more derived. Indeed, the Hunter-Schreger bands that are considered to strengthen the enamel by reducing the risk of cracks or fractures (Fortelius 1985; Pfretzschner 1994) are more developed than in Pr. sudrei, longer, wider and more regularly 
TABLE 2. - Synthetic table of measurements (in mm) of cheek teeth of Propalaeotherium cf. gaudryi (Lemoine, 1878) from Aumelas. LP/2-P/4 and LP/2-M/3 from composite data. Parameters: see Table 1. For individual data, see Appendix 4.

Propalaeotherium cf. gaudryi from Aumelas

\begin{tabular}{|c|c|c|c|c|c|c|c|c|c|c|c|c|c|c|c|c|c|c|}
\hline & \multicolumn{2}{|c|}{ P2/ } & \multicolumn{2}{|c|}{ P3/ } & \multicolumn{2}{|c|}{ P4/ } & \multicolumn{4}{|c|}{ M1/ } & \multicolumn{4}{|c|}{ M2/ } & \multicolumn{4}{|c|}{ M3/ } \\
\hline & $\mathbf{L}$ & $\mathbf{w}$ & $\mathbf{L}$ & W & $\mathbf{L}$ & $\mathbf{w}$ & $\mathbf{L}$ & $\mathbf{w}$ & D & d & $\mathbf{L}$ & $\mathbf{W}$ & D & d & $\mathbf{L}$ & $\mathbf{W}$ & D & d \\
\hline $\mathrm{N}$ & 3 & 3 & 3 & 3 & 6 & 6 & 4 & 4 & 4 & 5 & 7 & 6 & 7 & 7 & 11 & 11 & 11 & 10 \\
\hline mean & 7.7 & 7.1 & 8.5 & 10.2 & 8.8 & 12.3 & 11.5 & 14.0 & 14.6 & 13.7 & 12.9 & 15.5 & 16.8 & 15.0 & 13.4 & 15.6 & 17.0 & 14.7 \\
\hline variation & 7.0- & $6.7-$ & 8.0- & 9.3- & 8.4- & $11.5-$ & $11.2-$ & $13.7-$ & $14.1-$ & $13.4-$ & 12.0 & $14.2-$ & $15.8-$ & $14.3-$ & $12.8-$ & $14.3-$ & $15.5-$ & 13.7- \\
\hline range & 8.1 & 7.7 & 8.7 & 10.9 & 9.1 & 13.2 & 11.7 & 14.3 & 15.1 & 14.3 & 14.7 & 17.0 & 18.3 & 16.2 & 15.4 & 17.9 & 19.4 & 16.2 \\
\hline $\begin{array}{l}\text { standard } \\
\text { deviation }\end{array}$ & 0.608 & 0.529 & 0.404 & 0.808 & 0.250 & 0.672 & 0.208 & 0.275 & 0.569 & 0.419 & 0.854 & 0.903 & 0.914 & 0.668 & 0.897 & 1.023 & 1.100 & 0.758 \\
\hline $\begin{array}{l}\text { coeff. of } \\
\text { variation }\end{array}$ & 7.9 & 7.5 & 4.8 & 8.0 & 2.8 & 5.5 & 1.8 & 2.0 & 3.9 & 3.1 & 6.6 & 5.8 & 5.4 & 4.4 & 6.7 & 6.5 & 6.5 & 5.2 \\
\hline
\end{tabular}

\begin{tabular}{lcccc}
\hline upper series & LP2-M3 & LP2-P4 & LM1-M3 & PMI \\
\hline $\mathrm{N}$ & 3 & 3 & 4 & 3 \\
mean & 60.7 & 25.3 & 36.5 & 69.9 \\
variation range & $60.1-61.9$ & $24.2-26.2$ & $35.7-37.6$ & $67.8-71.4$ \\
standard deviation & 1.012 & 1.015 & 0.826 & 1.900 \\
coeff. of variation & 1.7 & 4.0 & 2.3 & 2.7 \\
\hline
\end{tabular}

\begin{tabular}{|c|c|c|c|c|c|c|c|c|c|c|c|c|c|c|c|c|c|c|c|}
\hline & \multicolumn{3}{|c|}{$\mathrm{P} / 2$} & \multicolumn{3}{|c|}{$P / 3$} & \multicolumn{3}{|c|}{$\mathrm{P} / 4$} & \multicolumn{3}{|c|}{ M/1 } & \multicolumn{3}{|c|}{ M/2 } & \multicolumn{4}{|c|}{ M/3 } \\
\hline & $\mathbf{L}$ & W1 & W2 & $\mathbf{L}$ & W1 & W2 & $\mathbf{L}$ & W1 & W2 & $\mathbf{L}$ & W1 & W2 & $\mathbf{L}$ & W1 & W2 & $\mathbf{L}$ & W1 & W2 & W3 \\
\hline $\mathrm{N}$ & 1 & 1 & 1 & 3 & 3 & 4 & 3 & 3 & 4 & 5 & 5 & 6 & 7 & 7 & 7 & 4 & 4 & 4 & 4 \\
\hline mean & 8.7 & 4.5 & 5.2 & 9.3 & 5.5 & 6.3 & 9.3 & 6.2 & 6.9 & 10.7 & 7.2 & 7.6 & 12.2 & 8.7 & 8.3 & 17.7 & 8.5 & 7.6 & 5.6 \\
\hline $\begin{array}{l}\text { variation } \\
\text { range }\end{array}$ & - & - & - & $\begin{array}{l}8.7- \\
10.1\end{array}$ & $\begin{array}{l}4.8- \\
6.1\end{array}$ & $\begin{array}{l}5.8- \\
6.4\end{array}$ & $\begin{array}{l}9.1- \\
9.5\end{array}$ & $\begin{array}{l}6.0- \\
6.4\end{array}$ & $\begin{array}{l}6.8- \\
7.1\end{array}$ & $\begin{array}{l}10.3- \\
11.3\end{array}$ & $\begin{array}{l}6.9- \\
7.7\end{array}$ & $\begin{array}{l}7.1- \\
8.2\end{array}$ & $\begin{array}{l}11.8- \\
12.7\end{array}$ & $\begin{array}{l}7.9- \\
9.2\end{array}$ & $\begin{array}{l}7.7- \\
9.0\end{array}$ & $\begin{array}{l}17.1- \\
18.3\end{array}$ & $\begin{array}{l}8.1- \\
8.8\end{array}$ & $\begin{array}{l}7.5- \\
7.7\end{array}$ & $\begin{array}{l}5.4- \\
5.8\end{array}$ \\
\hline $\begin{array}{l}\text { standard } \\
\text { deviation }\end{array}$ & - & - & - & 0.721 & 0.656 & 0.377 & 0.208 & 0.208 & 0.150 & 0.522 & 0.321 & 0.414 & 0.324 & 40.430 & 0.435 & 0.532 & 0.316 & 0.096 & 0.173 \\
\hline $\begin{array}{l}\text { coeff. of } \\
\text { variation }\end{array}$ & - & - & - & 7.8 & 11.9 & 6.0 & 2.2 & 3.3 & 2.2 & 4.9 & 4.5 & 5.5 & 2.7 & 4.9 & 5.2 & 3.0 & 3.7 & 1.3 & 3.1 \\
\hline
\end{tabular}

\begin{tabular}{lcccc}
\hline lower series & LP2-M3 & LP2-P4 & LM1-M3 & PMI \\
\hline $\mathrm{N}$ & 1 & 1 & 4 & 1 \\
mean & 68.1 & 27.3 & 40.8 & 66.9 \\
variation range & - & - & $40.0-41.6$ & - \\
standard deviation & - & - & 0.655 & - \\
coeff. of variation & - & - & 1.6 & - \\
\hline
\end{tabular}

arranged (Remy 1976: pl. 4, fig. 1-4, "Propalaeotherium parvulum Lissieu"; fig.6, "Propalaeotherium sp. Aumelas"). In the state of knowledge, not any specimen either can be assigned to Pr. sudrei in another Middle or Early Eocene locality (Remy et al. 2016).

\section{Propalaeotherium cf. gaudryi (Lemoine, 1878)} (Fig. 7)

MATERIAL. — AUM 47, right M3/; AUM 164, right maxillary fragment with M3/; AUM 168, right maxillary with canine and P1/ alveoli, P2/P3/-(P4/-M2/)-M3/; AUM 192, right P4/; AUM 209, right maxillary fragment with M1/-M3/; AUM 1583, palate with right P1/-M2/ and left P2/-M3/; AUM 1584, left maxilla with P2/-M3/; AUM 1585, left maxilla with (P2/)-(P3/)-P4/-M1/; AUM 1587, right M2/-M3/; AUM 1590, left M3/; AUM 1592, left M2/; AUM 1593, left M3/; AUM 1594, right P4/; AUM 1595, left M2/; AUM 1658, 1659, left M3/. AUM 206, right mandible with (alv.P/1-alv.P/2)-P/3-M/3 (Pr. sudrei in Remy \& al. 2016, fig. 3 E-F); AUM 236, right P/3; AUM 1560, right $\mathrm{P} / 3$; AUM 1561, right $\mathrm{P} / 2$; AUM 1601, right mandible with (P/4)-M/1M/3; AUM 1603, right mandible with (P/3)-P/4-M/3; AUM 1604, right mandible fragment with M/1-M/2; AUM 1606, left mandible with P/4-M/3; AUM 1607, right (M/1)-M/2; AUM 1608, left M/2.

\section{DESCRIPTION}

We gather some maxillaries or maxillary fragments of Propalaeotherium, which display differences with Propalaeotherium sudrei and that present larger measurements (Table 2). Indeed the upper cheek teeth row is on average 13\% longer (60$62 \mathrm{~mm}$ instead of $54 \mathrm{~mm}$ ), and the upper molar row is $16 \%$ longer $(36-38 \mathrm{~mm}$ instead of $32 \mathrm{~mm})$. All cheek teeth are on average $10 \%$ larger in linear measures. On lower cheek teeth, the length mean difference is of $8 \%$ (Appendices 16; 17). Upper teeth areas are about 30\% larger (Appendix 10). Lower teeth areas (Appendix 11) show less mean size difference (14\%). Most of these differences are significant ( $\mathrm{p}:<0.1$ to $<0.001)$. These measures support a body mass estimation of $34 \mathrm{~kg}$ (Appendix 8).

The upper molars are brachyodont with an average $\mathrm{I}_{\mathrm{H}}$ of 0.39 ( 0.34 to 0.45 ) (Appendix 12 ; Fig. 4). The size gradient from $\mathrm{M} 1 /$ to $\mathrm{M} 3$ / is important, but M2/ can be the largest 


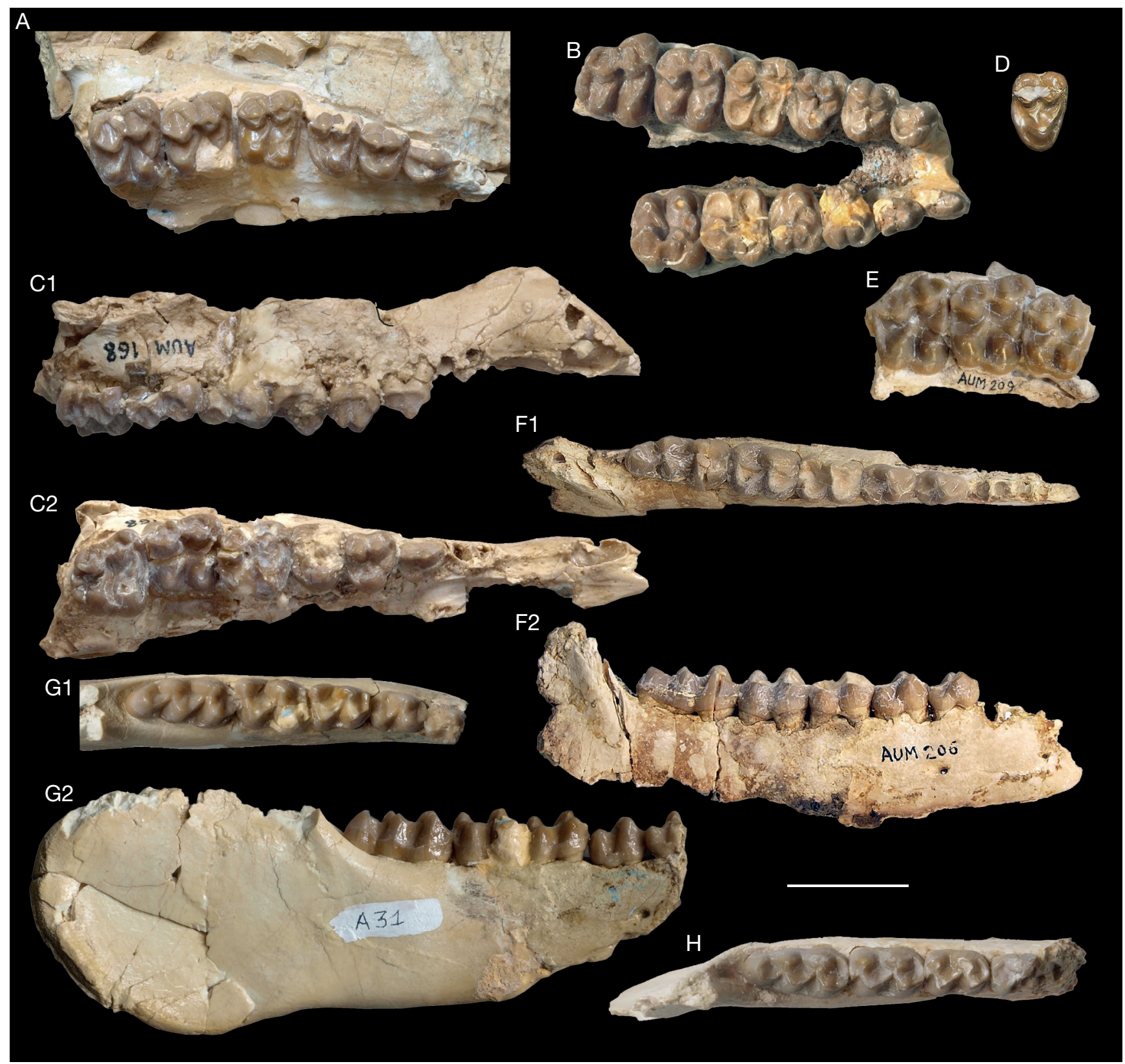

FIG. 7. - Propalaeotherium cf. gaudryi (Lemoine, 1878) from Aumelas: A, AUM 1584, left maxillary with (P1/ roots)-P2/-M3/, occlusal view (reversed); B, AUM 1583, maxillary with left P2/-M3/ and right P1/-M2/, occlusal view (reversed); C, AUM 168, right maxillary with (alv. C/)-(alv. P1/)-P2/-M3/; C1, labial view, C2, occlusal view; D, AUM 192, right P4/, occlusal view; E, AUM 209, right maxillary with M1/-M3/, occlusal view; F, AUM 206, right mandible with (alv. P/1-P/2)-P/3-M/3; F1, occlusal view; F2, labial view; G, AUM 1603, right mandible with (P/3)-P/4-M/3; G1, occlusal view; G2, labial view; H, AUM 1601, right mandible with (P/4)$\mathrm{M} / 1-\mathrm{M} / 3$, occlusal view. Scale bar: $2 \mathrm{~cm}$.

molar in some specimens (AUM 209; Fig. 7E). On these molars, which are trapezoidal, tapering distally, the hypocone is labially shifted. The ectoloph becomes increasingly oblique from $\mathrm{M} 1 /$ to $\mathrm{M} 3 /$. It is fairly flat, despite the presence of ribs on the cusps (especially on the paracone), and the centrocrista appears deeply notched on unworn specimens (AUM 209). The parastyle is moderately developed on $\mathrm{M} 1 /$ and becomes prominent outward on $\mathrm{M} 2 /$ and even more on $\mathrm{M} 3 /$. The ectocingulum is continuous and thick. The metastyle is only well-marked on $\mathrm{M} 3 /$. The mesostyle is rather narrow and protruding. It is not continuous with the ectocingulum like on Pr. sudrei, and it may lack at least on M3/ (AUM 209, AUM 1583). On protoloph, the groove between protocone and paraconule varies in depth. It is deep on the M2/ and M3/ on AUM 209, but it is shallower on other specimens (e.g. AUM 1583). The metaloph, which lacks discernible metaconule, runs first toward the distal side of the paracone, and turns to reach the mesio-lingual side of the metacone. The lingual cingulum is well developed on these molars. Although thin and disrupted in front of the cusps, the cingulum is continuous on some M1/ (AUM 209) and M2/ (AUM 1592), but limited to the medivallum on the M3/ (AUM 168). The 
distal outline of $\mathrm{M} 3$ / is convex, with a strong distal cingulum, which eventually bears small knobs (hypostyle) (AUM 168, AUM 1583).

The mean PMI is estimated to 70 (ranging from 68 to 71 ) and the mean $S_{\mathrm{P}} / S_{\mathrm{M}}$ surface ratio is 44 (ranging from 41 to 50; Appendix 9). $\mathrm{P} 4 /$ is transversely elongated ( $\mathrm{L} / \mathrm{W} 0.73$ on average). The labial cusps of $\mathrm{P} 4 /$ are bunodont and close to each other, separated by a groove. The centrocrista is slightly notched and lacks mesostyle. The ectocingulum is continuous, not salient and its external outline is strongly concave. The styles are rather low and variably protruding. The protocone is mesio-distally centered. The paraconule is well defined even if the groove between protocone and paraconule is not deeply notched. The lingual outline is variable, narrow on AUM 192, wider on AUM 1583 with a large posterior basin. On AUM 192 and AUM 1594, there is a small metaconule connected to a curved postprotocrista, a somewhat starry feature. A cingulum encircles the whole internal part of the tooth on most specimens (AUM 192 and AUM 1594), but it is interrupted at the protocone on AUM 1592, AUM 1584, and AUM 168 (very worn).

$\mathrm{P} 3$ / offers a similar shape but is less transversely elongated; AUM 1584 is almost quadratic. The bunodont labial cusps are slightly tighter than on $\mathrm{P} 4 /$. They display a labial continuous and concave cingulum. The parastyle is stronger and protrudes outward and forward. It appears weaker on AUM 168 with a metastyle as marked as parastyle. The lingual shape is wider than on P4/. It is even much enlarged on AUM 1584, which is nearly rectangular, with a slightly forwardly shifted protocone. Conversely on AUM 168, the internal contour remains narrow and the protocone is centered. The protoloph is not deeply notched and the paraconule is almost indistinct on AUM 1584 (more individualized on AUM 168). We note the presence of a postprotocrista that lacks a well-defined metaconule. Conversely, the metaconule is well marked on AUM 168, it is low and sinuous on AUM 1584. The lingual cingulum is always interrupted facing the protocone.

P2/ seems rather variable. On AUM 168 and AUM 1584, it is a triangular tooth, barely enlarged transversely and tapering forward. On the distal crest of the prominent paracone, which is remote forward, we note the presence of a small but rather individualized low metacone. The ectocingulum is continuous, rather weak, and less thick than on $\mathrm{P} 3 /$ and $\mathrm{P} 4 /$. Likewise the styles are weak. The internal part of the tooth is surrounded by a continuous cingulum. A rise of this cingulum, at the widest level of the tooth, evokes a small protocone. On AUM 1584 , a tiny knob is present at the place of the metaconule. AUM 1583 shows on the right P2/ a structure according to this description, but the left $\mathrm{P} 2$ / is transversely broader, with a well marked protocone and a rather wide posterior basin.

$\mathrm{P} 1 /$, partly preserved on the right side on AUM 1583, is a simple elongated tooth, surrounded by a circular cingulum, its prominent cusp is barely shifted oralwards. The two alveoli of P1/ are also to be seen on AUM 168. On both specimens, there was not any diastema between $\mathrm{P} 1 /$ and $\mathrm{P} 2 /$.

Ten lower jaw fragments or isolated teeth are related to this taxon (Fig. 7). The teeth are first characterized by their dimensions larger than those of Pr. sudrei (see above). Mor- phologically, this material offers little information to differentiate the taxon compared to other Propalaeotherium, because of the weak characterization of the lower cheek teeth and of individual variations. One can only observe that the crescents of the molars are fairly rounded, and their metaconid are generally well splitted. The labial cristid of the $M / 3$ hypoconulid is connected halfway to the hypolophid. The ectocingulum is quite variably developed.

Moreover, $\mathrm{P} / 4$ is rather bulbous; its talonid, a bit wider than on Pr. sudrei, is slightly lower than the trigonid; it does not show any hypolophid, but a tiny entoconid is present. $\mathrm{P} / 3$ is narrowed mesially and the crescent of the trigonid is very flat. The anterior cingulum lacks paraconid. The protoconid is linked to the metaconid through a very oblique protolophid. The talonid is short and the metalophid is low and oblique disto-labially, free of a well-developed hypoconid. Anterior teeth are not known.

Only few observations are available concerning the skull morphology. The alveolus of a rather large and mesio-distally elongated canine is preserved on AUM 168, which was likely pertaining to a male. This allows evaluating relative length of the DPC. It was $21 \mathrm{~mm}$ long with a LRDJ of $62 \mathrm{~mm}$, and the $\%$ DPC is estimated at 33.9 (Appendix 20A). The obliquity of the nasal opening edge suggests that the notch did not likely exceed the level of $\mathrm{P} 1 /$. The anterior opening of the infraorbital canal (FIO) is open $9 \mathrm{~mm}$ above the alveolar margin, its distal edge is very rostrally located, above the limit P2/-P3/.

The morphology of the mandible is also only partly known. The mandibular body is not very high (26 $\mathrm{mm}$ under $\mathrm{M} / 3$; AUM 1601, AUM 1603) and it seems not to be much lowered under the premolar row. A mental foramen opens under the limit P/3-P/4, and a smaller one under P/1 (AUM 206). The angular process is broad and is not ventrally protruding. The vertical ramus seems to have been high (AUM 1606).

\section{COMMENTS}

As already noticed, this material is significantly larger than that of Pr. sudrei. It is also greater than Pr. voigti (oUK to $\mathrm{MK})$ with differences averaging about $+8 \%$ in linear measures and about $+24 \%$ in surfaces ( $\mathrm{p}:<0.1$ to $<0.001$ for most parameters; Appendices 10; 18). Conversely, these Aumelas specimens are significantly smaller than those of Pr. hassiacum and Pr. isselanum.

As a result, their measures are only compatible with Pr. gaudryi from the Paris Basin or with the specimens of the Geiseltal uUK usually referred to Pr. voigti. The specimens from Rouzilhac (molassic beds of Issel, Aude, France), recently assigned to the taxon (Godinot et al. 2018) also seem to be about the same size. Actually, with the available material of Aumelas, differences of upper cheek teeth size relative to Pr. gaudryi are negligible. Likewise, as regards lower cheek teeth, the dimensions fall within variation ranges of that taxon (Appendices 16; 17).

Great morphological similarities are also observed at Aumelas with Pr. gaudryi. Like in Pr. gaudryi, a mesostyle is not always present on upper molars. The degree of brachyodonty is identical, more marked than on Pr. sudrei (Fig. 4). The enamel appears rather thick. 
Besides, we find as in Pr. gaudryi the great development of the parastyle of upper molars, the usually moderate splitting of the protoloph. The shape of the premolars $\mathrm{P} 3 /$ and $\mathrm{P} 4 /$ is similar, they are more transversally elongated than on Pr. sudrei. Moreover we may observe on $\mathrm{P} 4 / \mathrm{a}$ metaconule distally connected to the postprotocrista as on some specimens of Pr. gaudryi (NMB TS-83). Like in Pr. gaudryi, P2/ bears two distinct labial cusps. Its shape is rather variable, from triangular, anteriorly tapering, to almost quadratic. The material of the Geiseltal uUK up to now referred to as "Pr. voigti" (see above), which presents great similarities with these specimens, might also be close to Pr. gaudryi.

Nevertheless, the Aumelas material differs from Pr. gaudryi by several features that prevent a complete assimilation to this species, in the current state of knowledge. First, the relative surface of upper premolar area seems slightly greater (although the difference be not significant, failing sufficient documentation, and due to the variability of $\mathrm{P} 2 /$ ). Thus the $\mathrm{S}_{\mathrm{P} 4} / \mathrm{S}_{\mathrm{M} 3}$ ratio reaches 54 (50 to 61) instead of 51 (49 to 54 ) for $P r$. gaudryi). The material of Rouzilhac presents values close to those of Aumelas: the same ratio is $\mathbf{5 6}$ on the maxillary RZ-221 (Godinot et al. 2018: fig. 40-a). Then the lingual cingula are slightly less marked than with typical Pr. gaudryi, notably on premolars, and finally there is no P1/-P2/ diastema. These observations would attest to the slightly more progressive nature of the form of Aumelas (as well as that of Rouzilhac material, also recognized by the authors of the monograph) compared with Propalaeotherium gaudryi from the Paris basin.

Finally, the Aumelas material could be closer to the taxon of Rouzilhac than to that latter. However, the name of Propalaeotherium $\mathrm{cf}$. gaudryi is retained because of the meager fossil register

\section{Genus Pachynolophus Pomel, 1847}

TyPe SPECIES. - Pachynolophus duvali Pomel, 1847 by original designation.

InCluded SPeCIES. - Pa. cesserasicus Gervais, 1849; Pa. cayluxi (Filhol, 1888); Pa. livinierensis Savage, Russell \& Louis, 1965; Pa. garimondi Remy, 1967; Pa. boixedatensis Crusafont \& Remy, 1970, Pa. lavocati Remy, 1972; Pa. bretovensis Remy, 1988; Pa. molipontiensis Checa-Soler, 1994; Pa. zambranensis Badiola, Pereda-Suberbiola \& Cuesta, 2005; Pa. eulaliensis Danilo, Remy, Vianey-Liaud, Marandat, Sudre \& Lihoreau, 2013; Pa. gaytei Remy, 2015.

EXCLUDED SPECIES. - Pachynolophus hookeri Hooker, 1994 (synonym of Cymbalophus hookeri Godinot, 1987; see Danilo et al. 2013).

EMENDED DIAGNOSIS (after Danilo et al. 2013). — Small brachyodont equoids; nasal notch opening above the postcanine diastema, close to canine; confluent foramen ovale and middle lacerate foramen. Usually rather long DPC. Virtually complete set of cheek teeth with occasional lost of P1/1 in old individuals. Less bunodont dentition than in hyracotheres, up to fully lophodont. Mesostyle missing on upper molars, sometimes replaced by a "pseudomesostyle". Fairly developed conules. Generally weak cingula, less continuous and less high than in hyracotheres, phyletically tending to fade; the labial one frequently interrupted at paracone on upper molars. Non-molariform premolars with phylogenetic trend toward a reduction of their area relatively to molars. P3/-P4/ devoid of hypocone. Postero-lingual expansion of the distal outline of $\mathrm{P} 4 /$ in some species. Twinned metaconid on lower molars. Large hypoconulid basin on $M / 3$, with labial cristid of hypoconulid directed from entoconid to mid hypolophid. P/3-P/4 devoid of entoconid.

\section{Note}

Occasional absence of the first premolar on some specimens (e.g. FSL 3038 [Pa. livinierensis], ICP 3070 [Pa. boixedatensis]) could be ontogenetic in origin. This phenomenon was also observed in the genus Plagiolophus that bears relatively short premolar series like Pachynolophus (Remy 2004: 123). Indeed, many specimens of various Pachynolophus species retain their P1/1, what may be the original condition (e.g. Pa. cesserasicus FSL 2977, Pa. duvali MNHN CGR-82, Pa. lavocati MNHN Qu-7371, Pa. eulaliensis UM-SEL 45, SEL 88, SEL 05, an unpublished skull of $\mathrm{Pa}$. livinierensis in the Vidalenc' coll.).

\section{Pachynolophus ruscassierensis n. sp.} (Figs 8, 9)

\section{urn:Isid:zoobank.org:act:F10B45D3-0CC9-4CD4-8E38-0C568BBC7038}

TYPE SPECIMEN (HOLOTYPE). - UM-AUM 231 fragmentary skull preserved from nasal opening up to zygomatic arch, with right (alv. C/-P1/)-P2/-M3/ and left (alv. C/, P2/)-P3/-M3/ (Fig. 8B).

TyPe LOCALITY. - Aumelas, Hérault department, France.

ETYMOLOGY. - From the geographic locality; in Occitan language, "ruscassier" evokes a place covered with trees having rough bark.

Material. - AUM 48, left M1/; AUM 70, left P3/; AUM 138, right maxillary fragment with P4/-M2/; AUM 176, right M1/; AUM 186, left DP3/; AUM 187, left M1/; AUM 189, left M2/; AUM 191, right M1/; AUM 194, left M1/; AUM 197, M1/; AUM 210, right maxillary fragment with M3/; AUM 211, right M2/; AUM 216, left maxillary fragment with M1/-M2/; AUM 224, left M3/; AUM 235, left M1/ (cast); AUM 304, right M3/; AUM 321, left maxillary fragment with (M1/)-M2/; AUM 324, left maxillary fragment with M3/; AUM 1544, palate with right (alv. C/)-P1/, M1/-M3/ and left P1/, P4/-M3/; AUM 1545, AUM 1546, AUM 1564, left M1/-M2/; AUM 1552, left maxillary fragment with P2/(M3/); AUM 1553, left maxillary fragment with P3/-M2/; AUM 1554, right maxillary fragment with P4/-M2/; AUM 1555, right M2/; AUM 1563, right maxillary fragment with M2/-M3/; AUM 1565, left M2/; AUM 1566, right P3/; AUM 1567, left P4/; AUM 1618, right maxillary with DP2/-DP4/-M1/; AUM 1619, fragment of dislocated skull with right M1/-M2/; AUM 1628, left P3/-(M2/) (composite?); AUM 1632, right P3/; AUM 1634, left M3/. AUM 161, left mandible with M/1-M/3, alveoli of P/1-P/4; AUM 167 , mandible with symphysis, left $\mathrm{P} / 1-\mathrm{P} / 2$ and both canines; AUM 169 , right mandible fragment with $\mathrm{M} / 1-\mathrm{M} / 3$, alveoli of $\mathrm{P} / 3-\mathrm{P} / 4$; AUM 177, left mandible fragment with $\mathrm{M} / 1$; AUM 178, right $\mathrm{P} / 3$; AUM 185, right $M / 2 ; A U M ~ 217$, right $M / 2$; AUM 305, left $M / 2$; AUM 1549, right DP/4; AUM 1556, right mandible with (alv. $\mathrm{DP} / 2$ )-DP/3-M/2; AUM 1558, right M/2; AUM 1559, left M/1; AUM 1562, AUM 1612, right P/2; AUM 1568, right mandible with $\mathrm{M} / 2-\mathrm{M} / 3$; AUM 1569, right M/3; AUM 1570, left M/2(M/3); AUM 1571 right fragment with M/3; AUM 1575, right M/1; AUM 1578, AUM 1637, right P/3; AUM 1579, right P/1; AUM 1582, AUM 1621, AUM 1639, right M/1; AUM 1605, left mandible with (DP/3)-DP/4-M/2; AUM 1623, left M/1; AUM 1629, AUM 1636, AUM 1640, AUM 1642, AUM 1643, right P/4; AUM 1630, left DP/4; AUM 1631, AUM 1635, left (M/3); AUM 1638, right $\mathrm{M} / 3$; AUM 1641, right M/1; AUM 1657, left M/2. 
Diagnosis. - Rather large Pachynolophus species, LRDJ $=51$ $53 \mathrm{~mm}$; estimated weight about $21 \mathrm{~kg}$. Buno-lophodont dentition. Ectoloph of upper molars fairly flat, devoid of mesostyle and usually without pseudomesostyle. Deeply hollowed centrocrista. Relative surface of the premolar area not greatly reduced for a Pachynolophus, estimated at $44 \%$ of that of molars. Transversally elongated upper premolars, but with a lingual contour not specially narrowed. Rather straight lophids on lower molars; the transverse ones dug at midway. Labial crest of the M/3 hypoconulid connected to the mid hypolophid. Relatively thick and high cingula, almost wholly surrounding upper premolars, only missing on lingual side of lower molars. DPC of variable length but generally less elongated than in most other Pachynolophus.

DifFERENTIAL DiAGNOSIS. - Larger than most Pachynolophus species, except Pa. cayluxi. More lophodont dentition than that of Pa. eulaliensis and $\mathrm{Pa}$. cesserasicus, but much less than that of $\mathrm{Pa}$. lavocati and Pa. zambranensis. Centrocrista of upper molars more dug than those of Pa. bretovensis and Pa. garimondi. Greater relative surface of the premolar area than that of $\mathrm{Pa}$. molipontiensis, Pa. livinierensis, Pa. cesserasicus and Pa. lavocati. Less transversally elongated P4/ than in Pa. cayluxi, Pa. gaytei and Pa. cesserasicus with a less narrow lingual outline. Presence of a distinct metaconule on P4/, contrary to Pa. boixedatensis and M3/ not so large. Postero-lingual basin of P4/ less broad than that of Pa. bretovensis and Pa. garimondi. Thicker and higher cingula than in these latter species, wider also than in Pa. duvali.

\section{DESCRIPTION}

\section{Upper cheek teeth}

The type-specimen AUM 231 is in very good condition; only the M1/ bears notable signs of wear. It is a medium-sized Pachynolophinae (LRDJ $=51.3 \mathrm{~mm}$ ), slightly smaller than Propalaeotherium sudrei but larger than most hyracotheres. Dimensions of the whole material reported to the taxon suggest a body weight of about $21 \mathrm{~kg}$ following the equations in Janis (1990) (Appendix 8), with coefficients of size variability (V) mostly $<10 \%$ (Table 3 ). The dentition is characterized by its heterodonty with an increasing size from P2/ to M3/. The crowns are rather low. The $\mathrm{I}_{\mathrm{H}}$ index of AUM 231 reaches only 0.37 , but it is higher on other molars (AUM 324, AUM 191, AUM 194), up to 0.48-0.53 (Appendix 12).

The molar outlines become more trapezoidal backward from M1/ to M3/, narrowed distally, and only slightly transversally elongated. In spite of a global homogeneity in shape, some morphological variations are noticed. Ectoloph of M1/ can be less oblique than on the type-specimen (AUM 187), or on the contrary, more oblique (AUM 1564). M1/ can also be narrower distally with a labially shifted hypocone (AUM 176). Similarly, M3/ can have a more oblique ectoloph than on the holotype, with a recessed hypocone (AUM 224, AUM 324). The ectoloph is rather flat, though bearing a stout labial bulge on paracone. The metacone is slightly tilted inside and its labial bulge is less protruding. The centrocrista can be deeply notched (AUM 231, AUM 194) or only slightly dug (AUM 191, AUM 324, AUM 321). The parastyle is fairly strong and prominent on AUM 324, with the metastyle notably marked on M3/. The labial cingulum is not very salient although continuous and rather high on AUM 231. It is very thin and/or a bit interrupted on some specimens (AUM 138, AUM 187, AUM 191, AUM 1545). There is no mesostyle, although a slight crest is observed on mid ectoloph of the right M2/ of AUM 231.

The protoloph is directed towards parastyle and connects the preparacrista. The paraconule is elongated and linguodistally expanded. The groove separating paraconule and protocone is not deep on AUM 231, especially on M1/. It can be more dug (AUM 176, AUM 321) or conversely, hardly noticeable (AUM 210, AUM 189, AUM 191, AUM 1545). The metaloph, on which any individualized metaconule cannot be distinguished, is connected to the mesio-lingual side of the metacone. The internal outline of molars is hollowed at the level of the medivallum. The hypocone is only slightly receded labially with respect to the protocone. The whole inner part of molars are surrounded on AUM 231 by relatively well marked cingula, which weaken from M1/ to M3/ at lingual side and are interrupted on cusps. On other specimens, the lingual cingulum is thick (AUM 224, AUM 304), restricted to medivallum (AUM 324, AUM 187, AUM 321, AUM 1554) or even missing (AUM 210, AUM 191, AUM 138, AUM 235). The distal outline is slightly convex on most M3/, without hypostyle. On some specimens, it is more widened distally, without any raised cusp (AUM 324) or with a small typical hypostyle (AUM 224).

The surface of the premolar series relative to that of molars is low, as usual in Pachynolophus (Remy 1972). On AUM 231, the ratio SP/SM is estimated at 44 (Appendix 21) and the PMI at 65.7.

$\mathrm{P} 4 /$ is transversely elongated; the labial bulge of paracone and metacone is very marked and the centrocrista of ectoloph less notched than on molars. P3/ has an identical shape, but it is slightly less transversally elongated, with closer outer cusps and less notched centrocrista. As molars, the premolars exhibit some morphological variability. Indeed, some premolars differ markedly from homologous teeth of the holotype. Thus, some $\mathrm{P} 3 /$ and P4/ have a pronounced concavity of the labial outline (AUM 1553, AUM 1628). There is a strong labial cingulum on the P3/-P4/ of AUM 231, continuous and extended by a poorly developed parastyle. The latter can still be weaker (AUM 1544, AUM 1554 [P4/], AUM 1552, AUM 1566 [P3/]). The protocone of $\mathrm{P} 3 /-\mathrm{P} 4 /$ is generally axially located. It is slightly shifted forward on AUM 231, and even more forward on some P3/ (AUM 1552). The paraconule of these teeth is bulbous on AUM 231, rather separated from the protocone and clearly lower. It is weaker with the groove between paraconule and protocone being shallower on other specimens (AUM 1554 AUM 1567, AUM 1628). The rounded metaconule is labially extended by a thin rectilinear postprotocrista ridge oriented toward the centrocrista on AUM 231. The transverse lophs are more V-shaped with less distinct conules on AUM 1552 and AUM 1553. On the holotype, a thick and continuous cingulum surrounds the whole inner part of $\mathrm{P} 3 /-\mathrm{P} 4 /$ up to the ectoloph, but without any enlargement of a posterior basin unlike in some P3/ (AUM 1552, AUM 1553). The lingual cingulum is weaker and interrupted at protocone level on some P4/ (AUM 1554, AUM 1567) or P3/ (AUM 1552, AUM 1553). The P3/ (AUM 70), which displays a particularly weak and low metaconule, has a forward shifted protocone and lacks lingual cingulum. 


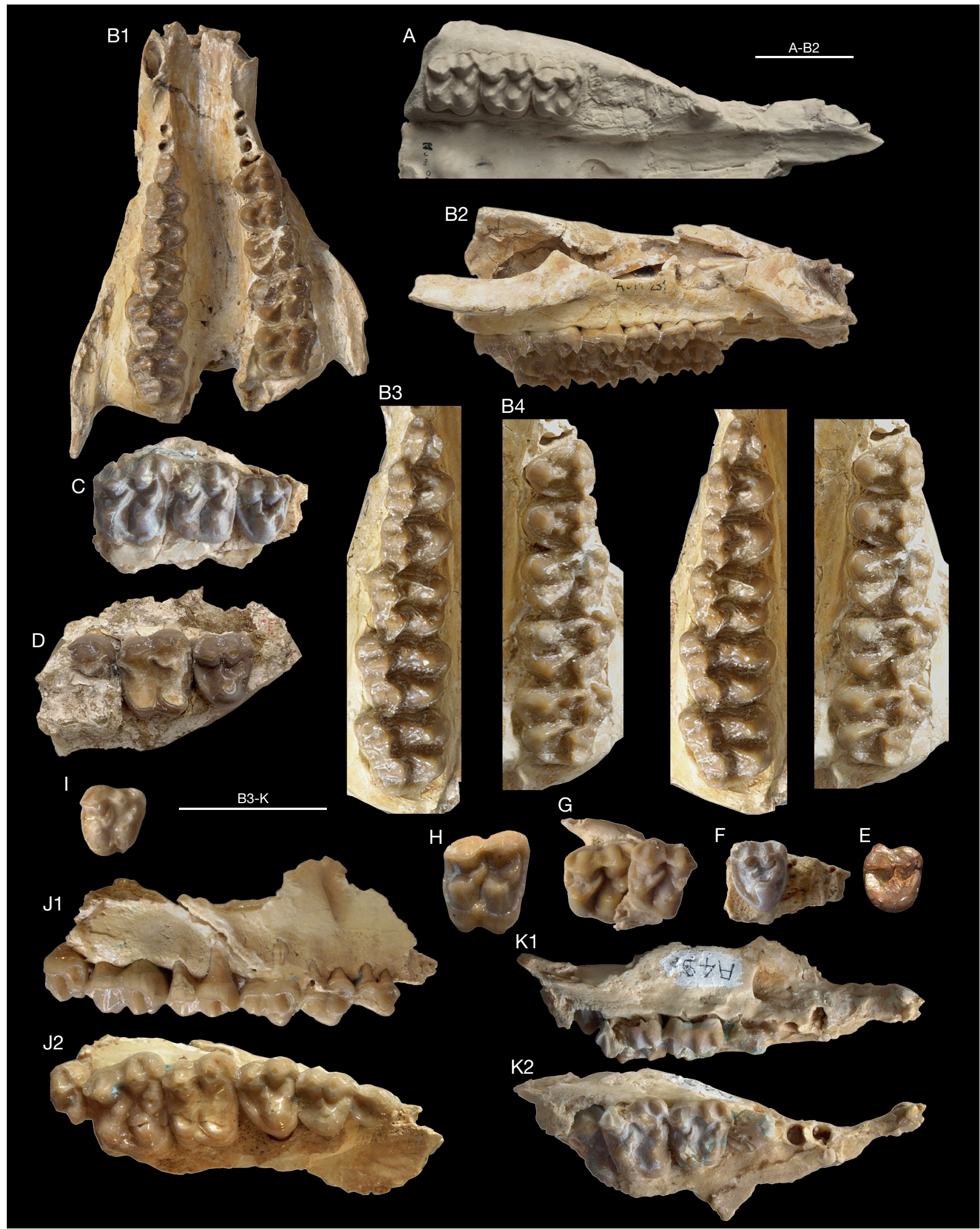

FIG. 8. - Pachynolophus ruscassierensis n. sp. from Aumelas: A, AUM 1544 (pars), right P1/, M1/-M3/, with alv. C/ and DPC (cast), occlusal view; B, AUM 231 (holotype), palate with right P2/-M3/ and left P3/-M3/; B1, occlusal view; B2, right labial view; B3, B4 (stereopairs), right and left cheek teeth; C, AUM 1554, right P4/-M2/, occlusal view; D, AUM 138, right P4/-M1/-(M2/), occlusal view; E, AUM 70, left P3/ (reversed), occlusal view; F, AUM 1567, left P4/ (reversed), occlusal view; G, AUM 321, left M1/-M2/ (reversed), occlusal view; H, AUM 304, right M3/, occlusal view; I, AUM 186, left DP4/, (reversed), occlusal view; J, AUM 1552, left maxilla with P2/-M2/(M3/) (reversed); J1, labial view; J2, occlusal view; K, AUM 1618, right maxilla with (alv. DP1/)-DP2/-DP4/-M1/; K1, labial view; K2,occlusal view. Scale bars: 2 cm. 
A P2/ is preserved on the holotype. It is a small ovoid tooth, narrow mesially and wide distally. It has two very close labial cusps with the metacone hard to individualize and lower than the paracone. The other known P2/ (AUM 1552) is a bit smaller and more rounded in shape. Its high labial cusp is extended distally by a crest devoid of any hint of an incipient metacone. The ectocingulum is faint and the styles poorly defined on AUM 231. The oblique lingual cingulum is enhanced by a small elongated protocone. In the distal basin, a tiny and very low crest evokes a faint preprotocrista. On AUM 1552, the protocone is more individualized and there is no crest in the worn basin.

The P1/ are preserved on AUM 1544. They are simple narrow teeth with a prominent cusp barely shifted rostrally and a surrounding cingulum. It seems that there was place for a short diastema between $\mathrm{P} 1 /$ and $\mathrm{P} 2 /$. The presence of a $\mathrm{P} 1 /$ is also attested on AUM 231 by two alveoli indicating a tooth as long but narrower than P2/. There was no P1/-P2/ diastema on this specimen. The alveolus of upper canine indicates a large and rather narrow tooth.

The deciduous dentition is known by an upper jaw (AUM 1618), whose teeth are unfortunately fractured and crumbled, and by a DP3/ (AUM 186). The DP4/ is molarized, has a high and rather protruding parastyle and lacks a mesostyle. The groove between paracone and protocone appears rather deep. The hypocone is less lingual in position than the protocone. The lingual cingulum is narrow and interrupted on hypocone. The DP3/ are also molariform but with a slightly oblique mesio-lingual outline. On AUM 186, the protocone is shifted labially relative to hypocone and slightly lower, with a deep lingual notch between protocone and hypocone. The paracone-protocone groove is shallower than on AUM 1618. The metaloph is curved on AUM 186 due to the presence of a small accessory distal cusp. The cingulum is thick and high, surrounding the tooth and only slightly broken at the paracone. $\mathrm{DP} 2 /$ is an elongated narrow triangular tooth. The paracone is prominent with a close low metacone. The parastyle is welldeveloped like an anterior cusp. The inner part of the tooth is chipped. DP1/, which is not preserved, had two roots.

\section{Lower cheek teeth (Fig. 9)}

The lower molars are characterized by rather pointed crescents. The lophids are rather straight and lophodont. The transverse ones appear to be dug midway when unworn. The trigonid is rather short, even shorter than talonid. The preprotocristid is lowered, and curved mesially, without any trace of paraconid. The metaconid is clearly splitted. The metalophid is connected between metaconid and metastylid. The hypoconulid is well developed on the middle of distal edge of $M / 1$ and $M / 2$. The labial crest of hypoconulid of $\mathrm{M} / 3$ reaches the middle of hypolophid and the curved lingual crest bears small knobs (AUM 161, AUM 169). The ectocingulum of molars is usually well marked, relatively high (about $2 \mathrm{~mm}$ for a total unworn cusp height of $6 \mathrm{~mm}$ on AUM 161) and fairly continuous (AUM 161, AUM 217), but can be weaker and more or less interrupted on cuspids (AUM 169, AUM 185, AUM 1568, AUM 1605). Not any lower molar bears a lingual cingulum.
The lower premolars are known only by isolated teeth. Those that we interpret as $\mathrm{P} / 4$ (see material) are rectangular and generally not narrowed mesially. The trigonid is molariform with a split metaconid (AUM 1640). The mesial crest of the protoconid is lowered; on AUM 1640 it terminates by a small, split paraconid. The talonid is slightly lower than the trigonid. The hypoconid is shifted labially. Although there is no entoconid, the hypoconid is sometimes extended by a low lingual cristid, a weak clue of an incipient cuspid (AUM 1642). The ectocingulum is generally weak, sometimes restricted to the medivallum (AUM 1629, AUM 1643). P/3 has an identical morphology, but the tooth tapers anteriorly, thus the trigonid is narrower than the talonid and somewhat more flattened (AUM 178). Like on $\mathrm{P} / 4$, the hypoconid is shifted labially, without any entoconid. The ectocingulum is rather weak. Three $\mathrm{P} / 2$ could be assigned to the species. They are simple teeth with one prominent cuspid (protoconid) slightly shifted rostrally. A parasagittal mesial ridge and a slightly linguo-distal one represent the relicts of the trigonid crescent. On AUM 1612, both ridges end with a very small knob. There is no true talonid, only another low parasagittal crest behind protoconid, terminated by a very small tubercle equivalent to a vestigial hypoconid. The ectocingulum is noticeable, but stopped on protoconid. P/1 (AUM 167), is an even more simple, bi-rooted tooth. The canines, also present on that specimen, are small suggesting it belongs to a female. The most complete canine (on the right) is eroded by a large distal surface of wear.

$\mathrm{DP} / 4$ is molariform but can be slightly narrow mesially (AUM 1605). It differs from the molars by the lower crown height and the thinness of the enamel (AUM 1630). The paralophid is devoid of a paraconid and the metaconid is clearly split. The talonid is as high as the trigonid and the entoconid as large as the hypoconid. The presence of an hypoconulid is noticeable. The ectocingulum is weak and interrupted on cuspids. DP/3 is narrow mesially but the crescent of the trigonid is fully developed (AUM 1556). An accessory small cuspid is observed on the lingual side of the mesial cristid of the protoconid. The talonid is wide and the entoconid is as high as the hypoconid like on DP/4.

\section{Other anatomical data}

The length of the post-canine diastema (DPC) appears variable in the sample. On a maxilla (AUM 231), it is relatively short (17 $\mathrm{mm}$, i.e. $33 \%$ of the length of the cheek teeth row LRDJ [L $\left.\mathrm{L}_{\mathrm{P} 2 / \mathrm{M} 3 /}\right]$, Appendix 20A), but on AUM 1544, it could have exceeded $50 \%$ of LRDJ. On mandibles, the length of the DPC can only be known indirectly on AUM 161, which preserves the molar row but is crushed in the premolar region. With a molar length of $33.6 \mathrm{~mm}$ and assuming a PMI between 0.67 and 0.70 (an average value for a Pachynolophus), the LRDJ length can be estimated at $56-57 \mathrm{~mm}$. Furthermore, the socket of the canine is missing and the part of the DPC preserved until the anterior alveolus of $\mathrm{P} / 2$ is $23 \mathrm{~mm}$ long. The DPC would not therefore have been lower than 40 or $41 \%$ of LRDJ. With a length of $33 \mathrm{~mm}$, the DPC of AUM 167 would have had a greater relative value, probably over 50\% (Appendix 20B). 
TABLE 3. - Synthetic table of measurements (in $\mathrm{mm}$ ) of cheek teeth of Pachynolophus ruscassierensis $\mathrm{n}$. sp. from Aumelas. Parameters: see Table 1. For individual data, see Appendix 5

Pachynolophus ruscassierensis $\mathbf{n} . \mathbf{s p}$.

\begin{tabular}{|c|c|c|c|c|c|c|c|c|c|c|c|c|c|c|c|c|c|c|}
\hline & \multicolumn{2}{|c|}{ P2/ } & \multicolumn{2}{|c|}{ P3/ } & \multicolumn{2}{|c|}{ P4/ } & \multicolumn{4}{|c|}{ M1/ } & \multicolumn{4}{|c|}{ M2/ } & \multicolumn{4}{|c|}{ M3/ } \\
\hline & $\mathbf{L}$ & $\mathbf{W}$ & $\mathbf{L}$ & W & $\mathbf{L}$ & W & $\mathbf{L}$ & W & D & d & $\mathbf{L}$ & $\mathbf{W}$ & D & d & $\mathbf{L}$ & W & D & d \\
\hline $\begin{array}{l}\mathrm{N} \\
\text { mean }\end{array}$ & $\begin{array}{c}2 \\
6.3\end{array}$ & $\begin{array}{l}2 \\
5.7\end{array}$ & $\begin{array}{l}7 \\
7.8\end{array}$ & $\begin{array}{l}7 \\
9.4\end{array}$ & $\begin{array}{c}8 \\
8.3\end{array}$ & $\begin{array}{c}8 \\
10.4\end{array}$ & $\begin{array}{l}18 \\
9.8\end{array}$ & $\begin{array}{c}18 \\
11.8\end{array}$ & $\begin{array}{c}17 \\
12.5\end{array}$ & $\begin{array}{r}19 \\
11.6\end{array}$ & $\begin{array}{c}18 \\
10.9\end{array}$ & $\begin{array}{c}19 \\
12.9\end{array}$ & $\begin{array}{c}18 \\
13.7\end{array}$ & $\begin{array}{c}18 \\
12.5\end{array}$ & $\begin{array}{c}11 \\
11.1\end{array}$ & $\begin{array}{c}11 \\
13.0\end{array}$ & $\begin{array}{c}11 \\
13.8\end{array}$ & $\begin{array}{c}11 \\
12.7\end{array}$ \\
\hline $\begin{array}{l}\text { variation } \\
\text { range }\end{array}$ & $\begin{array}{c}6.0- \\
6.5\end{array}$ & $\begin{array}{l}5.5- \\
5.8\end{array}$ & $\begin{array}{l}7.1- \\
8.5\end{array}$ & $\begin{array}{l}9.1- \\
9.9\end{array}$ & $\begin{array}{l}7.3- \\
9.2\end{array}$ & $\begin{array}{l}9.4- \\
11.6\end{array}$ & $\begin{array}{l}9.0- \\
10.7\end{array}$ & $\begin{array}{c}10.2- \\
13.2\end{array}$ & $\begin{array}{c}10.8- \\
14.6\end{array}$ & $\begin{array}{l}10.3- \\
12.9\end{array}$ & $\begin{array}{l}9.2- \\
12.2\end{array}$ & $\begin{array}{l}10.1- \\
14.7\end{array}$ & $\begin{array}{l}11.1- \\
15.9\end{array}$ & $\begin{array}{c}10.1- \\
14.2\end{array}$ & $\begin{array}{l}10.3- \\
12.1\end{array}$ & $\begin{array}{l}12.1- \\
14.3\end{array}$ & $\begin{array}{c}12.6- \\
15.4\end{array}$ & $\begin{array}{l}11.4- \\
13.9\end{array}$ \\
\hline $\begin{array}{l}\text { standard } \\
\text { deviation }\end{array}$ & - & - & 0.549 & 0.263 & 0.657 & 0.856 & 0.554 & 0.766 & 0.995 & 0.871 & 0.939 & 1.292 & 1.374 & 1.371 & 0.662 & 0.737 & 0.962 & 0.885 \\
\hline $\begin{array}{l}\text { coeff. of } \\
\text { variation }\end{array}$ & - & - & 7.0 & 2.8 & 8.0 & 8.3 & 5.7 & 6.5 & 8.0 & 7.5 & 8.6 & 10.0 & 10.0 & 11.0 & 5.9 & 5.7 & 6.9 & 7.0 \\
\hline
\end{tabular}

\begin{tabular}{|c|c|c|c|c|c|c|c|c|c|c|c|c|}
\hline & \multicolumn{4}{|c|}{ DP2/ } & \multicolumn{4}{|c|}{ DP3/ } & \multicolumn{4}{|c|}{ DP4/ } \\
\hline & $\mathbf{L}$ & w & D & d & $\mathbf{L}$ & W & D & d & $\mathbf{L}$ & W & D & d \\
\hline $\begin{array}{l}\mathrm{N} \\
\text { mean }\end{array}$ & $\begin{array}{l}1 \\
7.4\end{array}$ & $\begin{array}{l}1 \\
5.9\end{array}$ & $\begin{array}{l}1 \\
8.7\end{array}$ & $\begin{array}{l}1 \\
5.8\end{array}$ & $\begin{array}{l}2 \\
9.0\end{array}$ & $\begin{array}{c}2 \\
10.0\end{array}$ & $\begin{array}{c}2 \\
10.5\end{array}$ & $\begin{array}{l}2 \\
9.8\end{array}$ & $\begin{array}{l}1 \\
9.5\end{array}$ & $\begin{array}{c}1 \\
11.2\end{array}$ & $\begin{array}{c}1 \\
11.9\end{array}$ & $\begin{array}{c}1 \\
11.5\end{array}$ \\
\hline variation range & - & - & - & - & $\begin{array}{c}8.9- \\
9.0\end{array}$ & $\begin{array}{l}9.8- \\
10.1\end{array}$ & $\begin{array}{c}10.4- \\
10.6\end{array}$ & $\begin{array}{l}9.7- \\
9.8\end{array}$ & - & - & - & - \\
\hline
\end{tabular}

\begin{tabular}{lcccccc}
\hline upper series & LDPC & LP2-M3 & \%DPC & LP2-P4 & LM1-M3 & PMI \\
\hline $\mathrm{N}$ & 2 & 2 & 2 & 4 & 3 & 3 \\
mean & 22.3 & 52.2 & 42.5 & 21.8 & 31.9 & 68.4 \\
variation range & $17.0-27.5$ & $51.3-53.1$ & $33.1-51.8$ & $20.5-22.6$ & $31.2-32.4$ & $65.7-69.4$ \\
\hline
\end{tabular}

\begin{tabular}{|c|c|c|c|c|c|c|c|c|c|c|c|c|c|c|c|c|c|c|c|}
\hline & \multicolumn{3}{|c|}{$\mathrm{P} / 2$} & \multicolumn{3}{|c|}{$\mathrm{P} / 3$} & \multicolumn{3}{|c|}{$\mathrm{P} / 4$} & \multicolumn{3}{|c|}{ M/1 } & \multicolumn{3}{|c|}{$M / 2$} & \multicolumn{4}{|c|}{$M / 3$} \\
\hline & $\mathbf{L}$ & W1 & W2 & $\mathbf{L}$ & W1 & W2 & $\mathbf{L}$ & W1 & W2 & $\mathbf{L}$ & W1 & W2 & $\mathbf{L}$ & W1 & W2 & $\mathbf{L}$ & W1 & W2 & W3 \\
\hline $\mathrm{N}$ & 3 & 3 & 3 & 3 & 3 & 3 & 5 & 5 & 5 & 12 & 12 & 11 & 11 & 11 & 11 & 7 & 9 & 8 & 7 \\
\hline mean & 7.3 & 3.8 & 4.1 & 8.1 & 4.6 & 5.4 & 9.0 & 5.7 & 6.0 & 9.1 & 5.9 & 6.2 & 10.7 & 7.0 & 7.0 & 14.2 & 6.8 & 6.3 & 4.9 \\
\hline variation & $6.7-$ & $3.7-$ & 3.8- & 7.2- & 4.3- & $5.2-$ & 8.3- & $5.1-$ & $5.5-$ & 8.3- & 5.4- & $5.9-$ & 9.4- & $6.1-$ & $6.5-$ & 13.4- & 6.2- & 5.6- & 4.3- \\
\hline range & 7.6 & 3.9 & 4.3 & 8.7 & 4.7 & 5.8 & 9.3 & 6.0 & 6.2 & 10.2 & 6.5 & 6.8 & 12.4 & 8.1 & 7.8 & 15.2 & 7.7 & 7.1 & 5.9 \\
\hline standard & 0.520 & 0.100 & 0.265 & 0.814 & 0.231 & 0.321 & 0.412 & 0.356 & 0.277 & 0.550 & 0.291 & 0.401 & 0.927 & 0.625 & 0.395 & 0.655 & 0.559 & 0.677 & 0.568 \\
\hline $\begin{array}{l}\text { coeff. of } \\
\text { variation }\end{array}$ & 7.1 & 2.6 & 6.5 & 10.0 & 5.1 & 5.9 & 4.6 & 6.2 & 4.6 & 6.0 & 4.9 & 6.5 & 8.7 & 8.9 & 5.6 & 4.6 & 8.3 & 10.8 & 11.5 \\
\hline
\end{tabular}

\begin{tabular}{|c|c|c|c|c|c|c|c|c|c|}
\hline & \multicolumn{3}{|c|}{$\mathrm{DP} / 2$} & \multicolumn{3}{|c|}{$\mathrm{DP} / 3$} & \multicolumn{3}{|c|}{ DP/4 } \\
\hline & $\mathbf{L}$ & W1 & W2 & $\mathbf{L}$ & W1 & W2 & $\mathbf{L}$ & W1 & W2 \\
\hline $\mathrm{N}$ & - & - & - & 1 & 1 & 1 & 3 & 4 & 3 \\
\hline mean & - & - & - & 7.9 & 4.5 & 5.7 & 8.5 & 5.4 & 5.6 \\
\hline variation range & - & - & - & - & - & - & $8.3-8.7$ & $5.1-6.0$ & 5.4-5.9 \\
\hline $\begin{array}{l}\text { standard } \\
\text { deviation }\end{array}$ & - & - & - & - & - & - & 0.208 & 0.403 & 0.252 \\
\hline coeff. of variation & - & - & - & - & - & - & 2.5 & 7.4 & 4.5 \\
\hline lower series & LDPC & & LP2-M3 & & PC & LP2-P4 & LM & И1-M3 & PMI \\
\hline $\begin{array}{l}\mathrm{N} \\
\text { mean }\end{array}$ & $\begin{array}{c}1 \\
> \\
23.0\end{array}$ & & $\begin{array}{c}1 \\
56.7\end{array}$ & & & $\begin{array}{c}1 \\
22.5\end{array}$ & & $\begin{array}{c}2 \\
34.2\end{array}$ & $\begin{array}{c}1 \\
67.0\end{array}$ \\
\hline variation range & - & & - & & & - & 33. & $.6-34.8$ & - \\
\hline
\end{tabular}

In the Aumelas sample neither the deepness of the nasal notch on the skull, nor the shape of the premaxillary vertical apophysis are known. The FIO is rather rostrally situated, at $7 \mathrm{~mm}$ above P3/ (AUM 231, AUM 1552). On the juvenile AUM 1618, it appears above DP2/. The anterior edge of the orbit $(\mathrm{O})$ levels the mesial border of M2/. The orbital floor is very low (HTMX about $5 \mathrm{~mm}$ ), and moreover hilly by the relief of the roots of the last molars. The palate is slightly crushed (AUM 231) but appears hollow. It seems neverthe- less have been rather narrow after correction of that crash (taking into account the position of the spine of the median raphe). The maxillary zygomatic process, which is not very dorso-ventrally high (7 $\mathrm{mm}$ at orbit level) is expanded laterally, but the bow does not seem to have strongly diverged at the back, like on Pachynolophus livinierensis.

On AUM 161, the mandibular body is not very high and only increases slightly backwards ( $13.3 \mathrm{~mm}$ under DPC; $16.8 \mathrm{~mm}$ under $\mathrm{P} / 2 ; 23.4 \mathrm{~mm}$ under $\mathrm{M} / 3$ ). The values are close for 
AUM 169. On the juveniles AUM 1556 and AUM 1605, the mandibular height increases from $16 \mathrm{~mm}$ under $\mathrm{DP} / 3$ to $18 \mathrm{~mm}$ under $\mathrm{M} / 2$. Two mental foramina are noticeable, one under the limit $\mathrm{P} / 3-\mathrm{P} / 4$ and the second under $\mathrm{P} / 1-\mathrm{P} / 2$ (AUM 161). The vertical ramus is not preserved in Aumelas sample.

\section{Comments}

The described material of Aumelas can only be assigned to a Pachynolophus, based on the lack of mesostyle on upper molars, on the weak molarization of the premolars, especially with the upper ones devoid of hypocone. This form is first larger than most Pachynolophus species. Only one, Pa. cayluxi, known only by two upper premolars, $\mathrm{P} 3 /$ and $\mathrm{P} 4 /$, is markedly larger. The $\mathrm{P} 4 /$ of $\mathrm{Pa}$. cayluxi is also more transversely elongated with a narrower lingual contour.

On the contrary, the cheek teeth of the lower Eocene species Pa. eulaliensis are significantly smaller, as well as those of other potentially comparable Equoidea, Hyracotherium remyi or Orolophus maldani (on average 28 to $35 \%$ smaller than Aumelas' form). So great are these differences that it seems useless to present comparative tables of measures. Moreover, these species are on the whole more bunodont and slightly more brachyodont; the cingula are wider and higher. The parastyle of molars is more overflowing in $H$. remyi. The $\mathrm{P} 4 /$ of Pa. eulaliensis has a mesially shifted protocone and an accessory cusp lingual to the metacone.

The Middle Eocene genotypic species $P$ a. duvali is also smaller than the species of Aumelas with differences around 20\% for most parameters. The ectoloph of upper cheek teeth is less flat in Pa. duvali. P4/ and P3/ are lingually narrower, their lingual cingulum is weaker. According to the mandible MNHN CGR-89, the DPC should have been much longer. Then, Pa. livinierensis is about $25 \%$ smaller than the Aumelas' species with a smaller premolar sector and a proportionally greater surface ratio M3/ on M1/ (Appendix 21). The cingula are also weaker in Pa. livinierensis and the DPC longer. Pachynolophus gaytei, which is very small, has more transversely elongated and narrower premolars.

Two Spanish species have roughly the same size as that of Aumelas: Pachynolophus molipontiensis and Pa. boixedatensis. The former is characterized (Checa-Soler 1994, 1997: pl. 2 fig. 7) by its low premolar surface, with a very small $S_{P} / S_{M}$ ratio of only $34 \%$ instead of $44-49$ in the sample from Aumelas (Appendix 21). The second, which is however a bit smaller than the Aumelas' species, distinguishes chiefly by the less transversely elongated $\mathrm{P} 4 /$, with a more lophodont postprotocrista devoid of a conspicuous metaconule. Moreover, in Pa. boixedatensis, the DPC is likely longer (ICP 3368), the upper molars have an internal outline less recessed labially at the level of the hypocone, and the M3/ is proportionally larger.

The species Pa. cesserasicus, from the Minervois area, could present some affinities with the material from Aumelas but it is too badly defined and needs more extensive descriptions and complete revision (Savage et al. 1965) before concluding. Assuming that the featured specimen FSL-2977 could be a good representative of Pa. cesserasicus and that both parts of this specimen pertain to the same individual, we can observe that its size falls within the range of the sample from Aumelas. Besides, the lingual cingulum of premolars is almost continuous in both species. But significant differences are also observed and rules out assignment of the material of Aumelas to this taxon. Indeed, in Pa. cesserasicus the dentition seems more bunodont with more bulged cusps and less flattened ectolophs. The premolar area is smaller $\left(S_{\mathrm{P}} / S_{M}\right.$ $39 \%$; Appendix 21). P4/ is more transversely elongated and narrower on lingual side. The labial cusps of $\mathrm{P} 3 /$ are close to each other. Furthermore, Pa. cesserasicus has an extremely long DPC, the longest observed in any Pachynolophus.

Special attention must be brought to the Rouzilhac taxon attributed by Godinot et al. (2018) to "Propachynolophus" maldani (synonym of Orolophus maldani, see Remy 2017), which in fact has a size close to Pachynolophus ruscassierensis n. sp. according to the measures mentioned by the authors and from the published pictures.

The Rouzilhac material is much larger than the species of the Paris Basin. Indeed the length of $\mathrm{M} / 3$ varies between 13.5 and $15.7 \mathrm{~mm}$ at Rouzilhac (Godinot et al. 2018: table 12), vs a length of $10.9 \mathrm{~mm}$ for the holotype of O. maldani (MNHN AL-5199), and the length M/1-M/3 from 31.3 to $34.9 \mathrm{~mm}$ vs $23.5 \mathrm{~mm}$ (Appendix 25). Similar differences occur with upper cheek teeth. For most parameters, the sample of Rouzilhac is $+21 \%$ larger on average than the material of the species maldani, a highly significant difference $(\mathrm{p}=0.001)$.

Conversely molars of Pachynolophus ruscassierensis $\mathrm{n}$. sp. are rather similar in size to the Rouzilhac sample (at Aumelas, $\mathrm{L}_{\mathrm{M} / 3}$ 13.4-15.2 mm; $\left.\mathrm{L}_{\mathrm{M} / 1-\mathrm{M} / 3} 33.6-34.8 \mathrm{~mm}\right)$. Both samples share several anatomical features (on the skull, location of orbit and of FIO and level of choanae; at the mandible, length of DPC).

It might therefore be asked whether the Rouzilhac sample should be referred to the Aumelas species. Nevertheless, a large amount of arguments invalidates such a hypothesis.

First, whereas molars have almost similar size, the premolars are smaller at Rouzilhac (particularly P3/ and P/4). Thus in surface the premolar sector is smaller, revealing an unlike distribution of masticatory function $\left(\mathrm{S}_{\mathrm{P}} / \mathrm{S}_{\mathrm{M}} 39\right.$ on the upper series RZ-009, vs 44-49 at Aumelas [Appendix 21]; $S_{\mathrm{P} 2-\mathrm{P} 3 / 3 \mathrm{M}}$ 19 vs 25-28). Same differences occur with lower cheek teeth. Premolars are on average $12 \%$ smaller for most parameters $(-26 \%$ in area), these differences concerning above all the $\mathrm{P} / 4$ (significant up to level $\mathrm{p}=0.001$ ).

Besides, the upper molars of the Rouzilhac sample are more trapezoidal in shape, more bunodont, with not so flat ectolophs. In addition some bear a mesostyle, sometimes well defined (Godinot et al. 2018: 266), whereas this feature is seemingly totally absent in Pa. ruscassierensis $\mathrm{n}$. sp. The lower premolar ectocingulid is more pronounced at Rouzilhac. Finally the mandibular symphysis is lightly more elongated (ending at the level of $\mathrm{P} / 1$ instead of $5 \mathrm{~mm}$ further forward).

Thus, it seems that the Rouzilhac sample assigned by Godinot et al. to "Propachynolophus" maldani cannot be confused with Pachynolophus ruscassierensis n. sp. from Aumelas, and that it likely represents an original taxon also differing from Orolophus maldani of the Paris Basin.

Concerning the youngest Pachynolophus species, Pa. garimondi and Pa. bretovensis differ by thinner and lower cingula, 


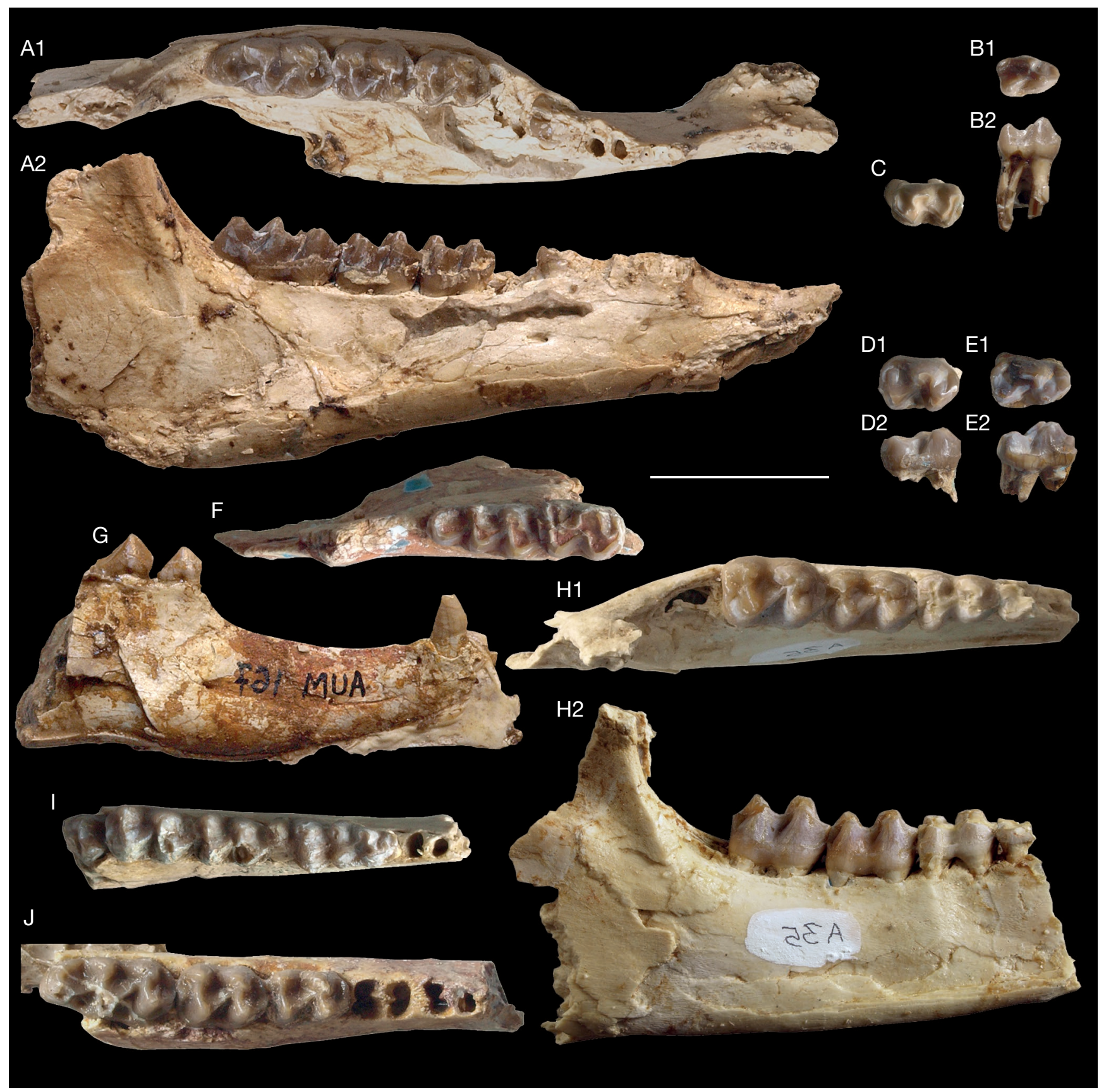

FIG. 9. - Pachynolophus ruscassierensis n. sp. from Aumelas: A, AUM 161, left mandible with (alv. /C), (roots P/1)-(alv. P/2)-(P/3), M/1-M/3 (reversed); A1, occlusal view (note that alignment of the tooth row is severely altered by a strong twisting); A2, labial view; B, AUM 178, right P/3; B1, occlusal view; B2, labial view; C, AUM 1630, right DP/4; occlusal view; D, AUM 1642, right P/4; D1, occlusal view; D2, labial view; E, AUM 1640, right P/4; E1, occlusal view; E2, labial view; F, AUM 1568, right mandible fragment with M/2-M/3; occlusal view; G, AUM 167, left mandible fragment (reversed) with /C, P/1-P/2; labial view; H, AUM 1605, left mandible (reversed) with (DP/3)-DP/4-M/2; H1, occlusal view; H2, labial view; I, AUM 1556, right mandible with (alv. DP/2)-DP/3-M/2-(M/3); occlusal view; J, AUM 169, right mandible with (alv. P/3, P/4)-M/1-M/3; occlusal view. Scale bar: $2 \mathrm{~cm}$.

by less deeply hollowed centrocristae on upper cheek teeth, and by a wider distal basin on P4/. Pachynolophus lavocati and Pa. zambranensis are distinguished by a more marked lophodonty than in specimens of Aumelas, including fully fused conules in transverse lophs, and Pa. lavocati presents a reduced premolar sector $\left(S_{\mathrm{P}} / S_{\mathrm{M}}=37 \%\right)$ (Appendix 21).

The species from Aumelas finally represents an original form that cannot be reported to any other known species of the genus. In the context of evolutive trends observed in Pachynolophus (e.g. Remy 2017: fig. 6, 18, supp. data 4, 12), this new species that we name Pa. ruscassierensis n. sp., combines likely archaic features (persistence of relatively thick and high cingula, not greatly reduced premolar sector, relatively short DPC) and some ones seemingly more derived (fairly flat ectoloph of upper molars, rather wide internal outline of the $\mathrm{P} /$ ). 


\section{Pachynolophus sp.}

(Fig. 10)

MATERIAL. - AUM 199, right maxillary fragment with P3/-M3/; AUM 213, left M3/; AUM 1586, right maxillary fragment with (alv. P1/)-P2/-(M2/); AUM 1596, left fragment with P3/-P4/; AUM 1648, 1649, left P4/. AUM 162, left mandible fragment with M/2, (M/3); AUM 227, left M/3 (Pr. sudrei in Remy et al. 2016); AUM 323, symphysis with both /C and sockets of incisors; AUM 332, right DP/4; AUM 1557, right M/3; AUM 1599 left mandible fragment with $(\mathrm{P} / 3)-(\mathrm{M} / 3)$; AUM 1600, right mandibular fragment with $\mathrm{M} / 2-\mathrm{M} / 3$; AUM 1602, left mandible fragment with $\mathrm{M} / 2-\mathrm{M} / 3$; AUM 1615, right mandible with P/4-M/3; AUM 1616, left fragment with M/3; AUM 1617, mandible with right /C-(alv. DP/1)$\mathrm{DP} / 2-\mathrm{M} / 3$, and (alv. six I and left /C); AUM 1620, left mandible with $\mathrm{DP} / 2-\mathrm{M} / 2-(\mathrm{M} / 3)$; AUM 1627 left mandible with $\mathrm{M} / 2-\mathrm{M} / 3$; AUM 1654, right M/3.

\section{DESCRIPTION}

The two featured upper cheek teeth series, AUM 199 and AUM 1586, are preserved in a very bad condition. AUM 199 which pertains to an old individual, is affected by a deep longitudinal fissure at the level of $\mathrm{P} 3 /-\mathrm{M} 2 /$ and the loss of ectoloph of M3/. The teeth of AUM 1586 are even more worn and molars partly broken.

These specimens and other associated upper cheek teeth present rather conspicuous differences compared to Pachynolophus ruscassierensis $\mathrm{n}$. sp. They are roughly $20 \%$ larger than average for most parameters. That would correspond to an estimated length of the row $\mathrm{P} 2 /-\mathrm{M} 3 /$ of at least $60 \mathrm{~mm}$, and to an estimated weight of $28 \mathrm{~kg}$ (instead of $52 \mathrm{~mm}, 21 \mathrm{~kg}$ for Pa. ruscassierensis n. sp.) (Table 4; Appendix 8).

As far as we can see, compared to Pa. ruscassierensis n. sp., the molars appear slightly more lophodont. The labial side of ectolophs is more slanted and indicates an $\mathrm{I}_{\mathrm{H}}$ index slightly lower. Thus the M3/ (AUM 213), although barely worn, has an $\mathrm{I}_{\mathrm{H}}$ of 0.40 , near the lower variation limit of Pa. ruscassierensis n. sp. (Appendix 12). The metaloph of molars, more forwardly oriented, is directed to the distal side of paracone. The cingula are on the whole thinner and likely lower. The distal cingulum of $\mathrm{M} 3$ / is nevertheless fairly prominent, and it can give rise to a small hypostyle (AUM 213). The occlusal faces of P3/ and $\mathrm{P} 4 /$ offer a more defined V shape. P3/ is more squared and has a wider lingual outline and a broader distal basin.

In addition, the surface ratio of the premolar sector appears to be slightly lower than that of Pa. ruscassierensis n. sp. Thus, $\mathrm{P} 4 /$ is somewhat smaller $\left(\mathrm{S}_{\mathrm{P} 4} / \mathrm{S}_{\mathrm{M} 3}=49\right.$ instead of 52-59) and the ratio $S_{\mathrm{P}} / S_{\mathrm{M}}$ (by combination of two specimens, AUM 199 and AUM 1586), could have reached only 38 to 42 instead of 44-49 (Appendix 21). P2/ is very unlike that of Pa. ruscassierensis $\mathrm{n}$. sp. as it is almost rectangular and possesses two distinct labial cusps.

Some mandibular fragments and lower teeth have been assigned to the same taxon on the basis of molar size. The crescents of the molars are rather sharp, not very rounded. The metastylid is not highly developed and poorly separated from metaconid. The ectocingulum is generally thin, variable in height (high on AUM 1599, lower on AUM 1617), and interrupted on cuspids except on AUM 1615. The P/4
(AUM 1599) is molariform, even if it bears only a small knob instead of a true entoconid. Its relative area is low compared to Pa. ruscassierensis n. sp. (Appendix 22). Despite P/3 (AUM 1599 ) is in a bad condition, we can see that the trigonid is long and tapers mesially. Its prominent protoconid overhangs a somewhat flattened crescent. The talonid is short and low, crossed by a weak ridge that ends in a small hypoconid.

$\mathrm{DP} / 4$ is fully molariform. On AUM 332, the metastylid is clearly separated from metaconid but slightly lowered. The $\mathrm{DP} / 3$ outline slightly tapers mesially and the paralophid bears a tiny lingual accessory cuspid (AUM 1620). DP/2 is simple, with a prominent cusp, overhanging small mesial and distal knobs, with a very short talonid. DP/1 was bi-rooted.

\section{Other anatomical data}

The upper DPC is not preserved. On the mandible AUM 1617 , the DPC (considered in that instance as the length /C-DP/2) measures $19.5 \mathrm{~mm}$. With a teeth row length of about $63 \mathrm{~mm}$, the DPC represents $31 \%$ of this value. But this specimen is a juvenile and is likely not representative of the adult condition. Due to its size, the mandibular fragment AUM 323 could perhaps be assigned to the same taxon. It shows a symphysal region not reaching alveoli of the $\mathrm{P} / 1$, but with both /C and the sockets of incisors. The preserved part of diastema is $24 \mathrm{~mm}$ long; assuming at least $6 \mathrm{~mm}$ for P/1 length (the DPC being the distance /C-P/2), with a tooth row length of $60 \mathrm{~mm}$ (estimation for AUM 199) to $63 \mathrm{~mm}$ (AUM 1617), this DPC $(24+6)$ should have reached 48 to $50 \%$ of LRDJ.

The mandibular body is more robust than that of $\mathrm{Pa}$. ruscassierensis $\mathrm{n}$. sp., high from $16 \mathrm{~mm}$ under the DPC, to $28 \mathrm{~mm}$ under $\mathrm{M} / 3$, with a minimal width of 12 to $16 \mathrm{~mm}$ at the DPC. On AUM 1617, a single foramen mentale is observed under $\mathrm{DP} / 2$. The vertical ramus is unknown.

At maxillary level, the anterior opening of the infra-orbital foramen (FIO) is located above anterior half of P3/ (AUM 1586).

\section{COMMENTS}

The generic status of this assemblage needs some comments. It can be a priori assigned to Pachynolophus due to lack of mesostyle on upper molars, lack of hypocone or entoconid on premolars, rather sharp crescents on lower cheek teeth, long DPC. But, one might wonder whether these specimens should not rather refer to Propalaeotherium cf. gaudryi from Aumelas. Indeed, their size is identical, with variation limits overlapping almost exactly. Moreover, we know that some specimens lack mesostyle in Propalaeotherium gaudryi (Remy 2017). On the other hand several features clearly differentiate this cluster. First, the relative surface area of the premolar series seems smaller than in Pr. cf. gaudryi from Aumelas, (actually more alike than data observed in the true Pr. gaudryi !). Thus $\mathrm{P} 4 /$ is rather small $\left(\mathrm{S}_{\mathrm{P} 4} / \mathrm{S}_{\mathrm{M} 3}=49\right.$ instead of 50-61 in Pr. cf. gaudryi; $\mathrm{S}_{\mathrm{P} 4} / \mathrm{S}_{\mathrm{M}}=18$ instead of 19-22). Then, we speculate that the total surface of the premolars represents only 38 to $42 \%$ of the surface of the molars instead of 41 to $50 \%$ in Pr. cf. gaudryi (Appendices 9; 21 [caption]). 


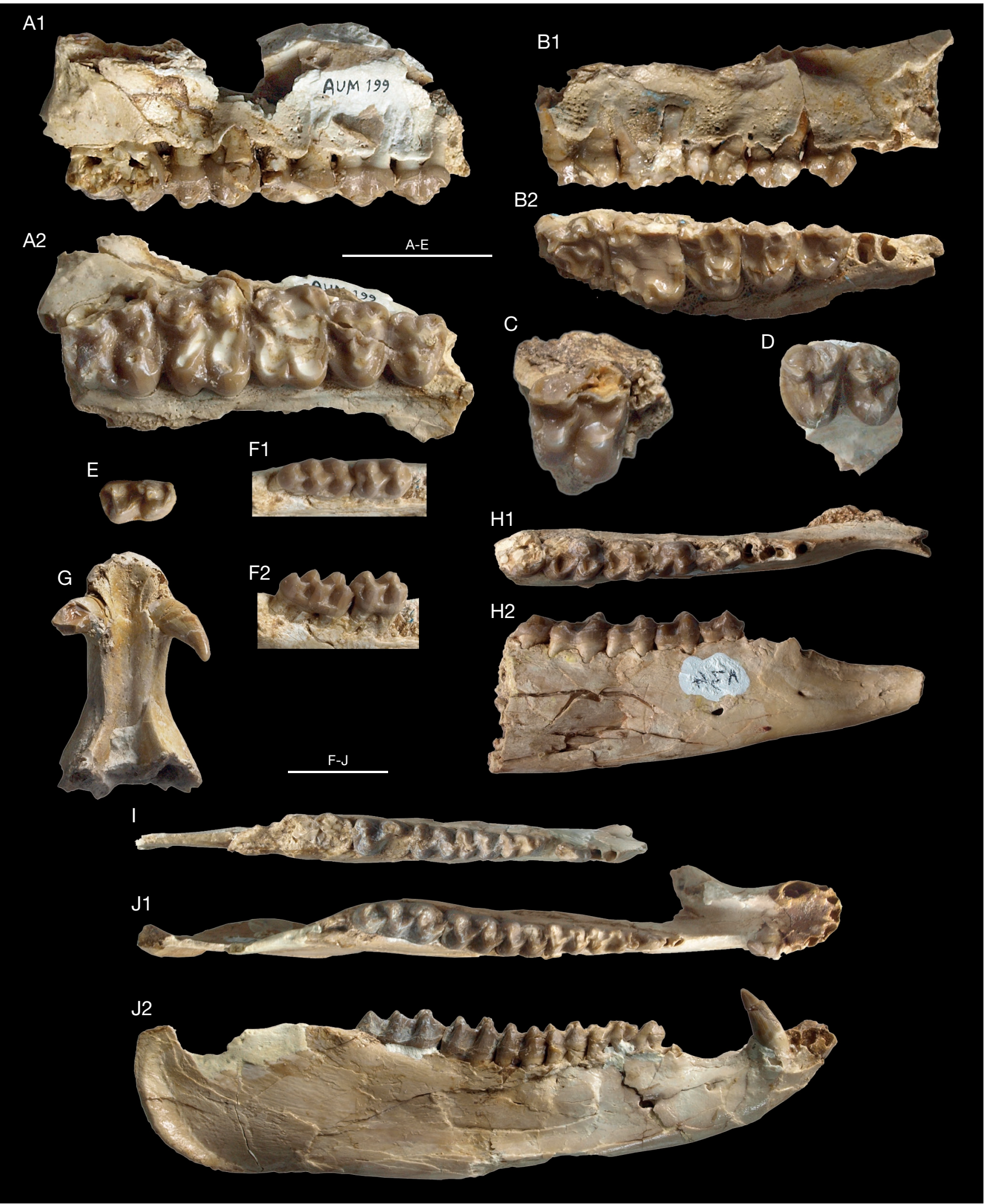

FIG. 10. - Pachynolophus sp. from Aumelas: A, AUM 199, right maxillary fragment with P3/-M3/; A1, labial view; A2, occlusal view; B, AUM 1586, right maxillary fragment with (alv. P1/)-P2/-(M2/); B1, labial view; B2, occlusal view; C, AUM 213, left M3/(reversed), occlusal view; D, AUM 1596, left fragment with P3/-P4/ (reversed), occlusal view; E, AUM 332, right DP/4, occlusal view; F, AUM 1600, right mandible with M/2-M/3 (pars); F1, occlusal view; F2, labial view; G, AUM 323, symphysis with both /C and sockets of incisors, dorsal view; H, AUM 1599 left mandible fragment with (P/3)-(M/3) (reversed); H1, occlusal view; H2, labial view; I, AUM 1620, left mandible with DP/2-M/2-(M/3), occlusal view; J, AUM 1617, mandible with right /C-(alv. DP/1)-DP/2-M/3, sockets of incisors and left /C); J1, occlusal view; J2, labial view. Scale bars: $2 \mathrm{~cm}$. 
TABLE 4. - Synthetic table of measurements (in $\mathrm{mm}$ ) of cheek teeth of Pachynolophus sp. from Aumelas and comparison with Pa. ruscassierensis $\mathrm{n}$. sp. (1) LP2/ supposed from AUM 1586. Parameters: see Table 1. For individual data, see Appendix 6. Significance probabilities established from Student's t-test.

Pachynolophus sp. from Aumelas

\begin{tabular}{|c|c|c|c|c|c|c|c|c|c|c|c|c|c|c|c|c|c|c|}
\hline & \multicolumn{2}{|c|}{ P2/ } & \multicolumn{2}{|c|}{ P3/ } & \multicolumn{2}{|c|}{ P4/ } & \multicolumn{4}{|c|}{ M1/ } & \multicolumn{4}{|c|}{ M2/ } & \multicolumn{4}{|c|}{ M3/ } \\
\hline & $\mathbf{L}$ & $\mathbf{w}$ & $\mathbf{L}$ & w & $\mathbf{L}$ & $\mathbf{w}$ & $\mathbf{L}$ & $\mathbf{w}$ & D & d & $\mathbf{L}$ & $\mathbf{w}$ & D & d & $\mathbf{L}$ & w & D & d \\
\hline $\begin{array}{l}\mathrm{N} \\
\text { mean }\end{array}$ & 1 & 1 & 3 & 3 & $\begin{array}{c}5 \\
88\end{array}$ & 5 & 2 & 1 & 1 & 2 & 1 & 1 & 1 & 1 & 2 & 2 & 2 & 1 \\
\hline mean & 7.3 & 7.4 & & 10.1 & 8.8 & 11.2 & & & & 13.8 & 13.6 & 16.2 & 17.9 & 16.1 & 14. & 16.5 & 17.2 & 16.3 \\
\hline $\begin{array}{l}\text { variation } \\
\text { range }\end{array}$ & - & - & $7.4-8.2$ & $9.3-10.8$ & $8.2-9.4$ & $\begin{array}{c}10.7- \\
11.8\end{array}$ & $\begin{array}{c}10.1- \\
10.8\end{array}$ & - & - & $\begin{array}{c}13.2- \\
14.3\end{array}$ & - & - & - & - & $\begin{array}{c}14.0- \\
14.1\end{array}$ & $\begin{array}{r}16.1- \\
16.8\end{array}$ & $\begin{array}{c}17.1- \\
17.3\end{array}$ & - \\
\hline $\begin{array}{l}\text { standard } \\
\text { deviation }\end{array}$ & - & - & 0.436 & 0.764 & 0.537 & 0.527 & - & - & - & - & - & - & - & - & - & - & - & - \\
\hline $\begin{array}{l}\text { coeff. of } \\
\text { variation }\end{array}$ & - & - & 5.7 & 7.5 & 6.1 & 4.7 & - & - & - & - & - & - & - & - & - & - & - & - \\
\hline
\end{tabular}

Comparison with Pa. ruscassierensis $\mathrm{n} . \mathrm{sp}$.

\begin{tabular}{|c|c|c|c|c|c|c|c|c|c|c|c|c|c|c|c|c|c|c|}
\hline & \multicolumn{2}{|c|}{ P2/ } & \multicolumn{2}{|c|}{ P3/ } & \multicolumn{2}{|c|}{ P4/ } & \multicolumn{4}{|c|}{ M1/ } & \multicolumn{4}{|c|}{ M2/ } & \multicolumn{4}{|c|}{ M3/ } \\
\hline & $\mathbf{L}$ & w & L & $\mathbf{w}$ & $\mathbf{L}$ & w & $\mathbf{L}$ & $\mathbf{w}$ & D & d & $\mathbf{L}$ & $\mathbf{w}$ & D & d & $\mathbf{L}$ & $\mathbf{w}$ & D & d \\
\hline $\begin{array}{l}\text { degree of } \\
\text { freedom }\end{array}$ & 1 & 1 & 8 & 8 & 11 & 11 & 18 & 17 & 16 & 19 & 17 & 18 & 17 & 17 & 11 & 11 & 11 & 10 \\
\hline $\begin{array}{l}\mathrm{t}(P . \mathrm{sp} . / \\
\quad \text { ruscassier }\end{array}$ & 2.425 & 6.736 & -0.195 & 2.509 & 0.847 & 0.952 & 1.153 & 3.006 & 2.235 & 2.366 & 2.798 & 2.500 & 2.960 & 2.560 & 5.889 & 5.953 & 4.7023 & 3.936 \\
\hline $\begin{array}{l}\text { signification } \\
\text { ratio (P. sp./ } \\
\text { ruscassier) }\end{array}$ & $\begin{array}{c}\text { NS } \\
116.8\end{array}$ & $\begin{array}{c}\text { NS } \\
131.0\end{array}$ & $\begin{array}{l}\text { NS } \\
98.5\end{array}$ & $\begin{array}{c}\text { NS } \\
107.5\end{array}$ & $\begin{array}{c}\text { NS } \\
107.2\end{array}$ & $\begin{array}{c}\text { NS } \\
108.3\end{array}$ & $\begin{array}{c}90 \\
106.7\end{array}$ & $\begin{array}{c}99 \\
120.0\end{array}$ & $\begin{array}{c}98 \\
118.3\end{array}$ & $\begin{array}{c}99 \\
118.2\end{array}$ & $\begin{array}{c}90 \\
124.8\end{array}$ & $\begin{array}{c}95 \\
125.7\end{array}$ & $\begin{array}{c}98 \\
130.4\end{array}$ & $\begin{array}{c}90 \\
128.9\end{array}$ & $\begin{array}{c}99 \\
126.1\end{array}$ & $\begin{array}{c}99 \\
127.0\end{array}$ & $\begin{array}{c}98 \\
124.31\end{array}$ & $\begin{array}{c}95 \\
128.7\end{array}$ \\
\hline
\end{tabular}

\begin{tabular}{lrrrr}
\hline upper series & LP2-M3 & LP2-P4 & LM1-M3 & \multicolumn{1}{c}{ PMI } \\
\hline $\mathrm{N}$ & 1 & 1 & 1 & 1 \\
mean & 60.6 & $24.3(1)$ & 36.3 & 67.1 \\
\hline
\end{tabular}

\begin{tabular}{|c|c|c|c|c|c|c|c|c|c|c|c|c|c|c|c|c|c|c|c|}
\hline & \multicolumn{3}{|c|}{$\mathrm{P} / 2$} & \multicolumn{3}{|c|}{$P / 3$} & \multicolumn{3}{|c|}{$\mathrm{P} / 4$} & \multicolumn{3}{|c|}{ M/1 } & \multicolumn{3}{|c|}{$\mathrm{M} / 2$} & \multicolumn{4}{|c|}{$M / 3$} \\
\hline & $\mathbf{L}$ & W1 & W2 & $\mathbf{L}$ & W1 & W2 & $\mathbf{L}$ & W1 & W2 & L & W1 & W2 & L & W1 & W2 & $\mathbf{L}$ & W1 & W2 & W3 \\
\hline \multirow{5}{*}{$\begin{array}{l}\mathrm{N} \\
\text { mean } \\
\text { variation } \\
\quad \text { range } \\
\text { standard } \\
\quad \text { deviation } \\
\text { coeff. of } \\
\quad \text { variation }\end{array}$} & 1 & 1 & 1 & 1 & - & - & 2 & 2 & 2 & 4 & 4 & 4 & 8 & 7 & 8 & 9 & 9 & 9 & 9 \\
\hline & 6.7 & 3.8 & 3.8 & 8.6 & - & - & 9.0 & 6.6 & 6.6 & 9.9 & 7.3 & 7.7 & 11.8 & 8.3 & 8.3 & 17.2 & 8.7 & 7.7 & 5.9 \\
\hline & - & - & - & - & - & - & 8.6- & 6.5- & 6.3- & $\begin{array}{l}9.6- \\
10 ?\end{array}$ & 6.7- & 7.2- & $\begin{array}{c}11.5- \\
121\end{array}$ & 7.9- & $\begin{array}{l}7.9- \\
8.7\end{array}$ & 16.2- & 8.5- & $7.1-$ & 5.6- \\
\hline & - & - & - & - & - & - & - & - & - & 0.258 & 0.457 & 0.392 & 0.217 & 0.416 & 0.251 & 0.893 & 0.201 & $\begin{array}{l}0.387 \\
0.387\end{array}$ & 0.310 \\
\hline & - & - & - & - & - & - & - & - & - & 2.6 & 6.3 & 5.1 & 1.8 & 5.0 & 3.0 & 5.2 & 2.3 & 5.0 & 5.2 \\
\hline
\end{tabular}

Comparison with $\mathrm{Pa}$. ruscassierensis $\mathrm{n}$. sp.

\begin{tabular}{|c|c|c|c|c|c|c|c|c|c|c|c|c|c|c|c|c|c|c|c|}
\hline & \multicolumn{3}{|c|}{$\mathrm{P} / 2$} & \multicolumn{3}{|c|}{$P / 3$} & \multicolumn{3}{|c|}{$\mathrm{P} / 4$} & \multicolumn{3}{|c|}{ M/1 } & \multicolumn{3}{|c|}{$\mathrm{M} / 2$} & \multicolumn{4}{|c|}{$M / 3$} \\
\hline & $\mathbf{L}$ & W1 & W2 & $\mathbf{L}$ & W1 & W2 & $\mathbf{L}$ & W1 & W2 & $\mathbf{L}$ & W1 & W2 & $\mathbf{L}$ & W1 & W2 & $\mathbf{L}$ & W1 & W2 & W3 \\
\hline $\begin{array}{l}\text { degree of } \\
\text { freedom }\end{array}$ & 2 & 2 & 2 & 2 & - & - & 5 & 5 & 5 & 14 & 14 & 13 & 17 & 16 & 17 & 14 & 16 & 15 & 14 \\
\hline $\begin{array}{l}\mathrm{t}(P . \mathrm{sp} . / \\
\quad \text { ruscassier })\end{array}$ & -1.000 & 0.000 & -0.982 & 0.496 & - & - & -0.139 & 3.237 & 2.315 & 2.616 & 6.926 & 6.601 & 3.425 & 4.970 & 7.736 & 7.482 & 9.990 & 5.362 & 4.437 \\
\hline $\begin{array}{c}\text { signification } \\
\text { ratio }(P . \text { sp./ } \\
\text { ruscassier) }\end{array}$ & $\begin{array}{r}\text { NS } \\
91.8\end{array}$ & $\begin{array}{r}\text { NS } \\
100.0\end{array}$ & $\begin{array}{r}\text { NS } \\
92.7\end{array}$ & $\begin{array}{r}\text { NS } \\
105.7\end{array}$ & $\begin{array}{l}- \\
-\end{array}$ & $\begin{array}{l}- \\
-\end{array}$ & $\begin{array}{r}\text { NS } \\
99.4\end{array}$ & $\begin{array}{c}95 \\
115.4\end{array}$ & $\begin{array}{c}90 \\
109.5\end{array}$ & $\begin{array}{c}95 \\
108.3\end{array}$ & $\begin{array}{r}99.9 \\
122.4\end{array}$ & $\begin{array}{r}99.9 \\
124.9\end{array}$ & $\begin{array}{c}99 \\
110.8\end{array}$ & $\begin{array}{r}99.9 \\
119.1\end{array}$ & $\begin{array}{r}99.9 \\
117.6\end{array}$ & $\begin{array}{r}99.9 \\
121.2\end{array}$ & $\begin{array}{r}99.9 \\
129.2\end{array}$ & $\begin{array}{r}99.9 \\
122.5\end{array}$ & $\begin{array}{r}99.9 \\
119.9\end{array}$ \\
\hline
\end{tabular}

\begin{tabular}{|c|c|c|c|c|c|c|c|c|c|}
\hline & \multicolumn{3}{|c|}{$\mathrm{DP} / 2$} & \multicolumn{3}{|c|}{$\mathrm{DP} / 3$} & \multicolumn{3}{|c|}{ DP/4 } \\
\hline & $\mathbf{L}$ & W1 & w2 & $\mathbf{L}$ & W1 & w2 & L & W1 & W2 \\
\hline $\mathrm{N}$ & 2 & 2 & 2 & 2 & 2 & 2 & 3 & 3 & 3 \\
\hline mean & 7.4 & 3.1 & 3.8 & 8.9 & 4.7 & 5.7 & 9.6 & 5.9 & 6.4 \\
\hline $\begin{array}{c}\text { variation } \\
\text { range }\end{array}$ & 7.3-7.4 & $3.1-3.1$ & $3.7-3.9$ & $8.4-9.3$ & $4.6-4.7$ & $5.6-5.7$ & $9.1-10.3$ & $5.5-6.2$ & $5.9-6.8$ \\
\hline $\begin{array}{l}\text { standard } \\
\text { deviation }\end{array}$ & - & - & - & - & - & - & 0.643 & 0.361 & 0.458 \\
\hline $\begin{array}{l}\text { coeff. of } \\
\text { variation }\end{array}$ & - & - & - & - & - & - & 6.7 & 6.1 & 7.2 \\
\hline
\end{tabular}


Some morphological differences are also conspicuous between the upper cheek teeth and those of Pr. cf. gaudryi from Aumelas as well as with those of Pr. gaudryi from the "Ageian fauna". The parastyle of molars is a slightly less prominent. $\mathrm{P} 3$ / and $\mathrm{P} 4$ / have a more mesially shifted protocone with a broader distal basin. P2/ shows a more rectangular outline, with two more separated labial cusps. The lingual cingula are less developed.

The associated mandibular specimens confirm this differentiation with respect to the lineage of Pr. gaudryi. Indeed, the crescents of the lobes of lower cheek teeth are less rounded and more acute. The DPC is likely longer than in Pr. gaudryi where it should not exceed 30 to 32\% of LRDJ (Remy 2017). Conversely, we have seen that on the mandible AUM 323, it could have reached $50 \%$.

It seems that this set of specimens from Aumelas should not finally be brought close to a Propalaeotherium, and must rather be assigned to the genus Pachynolophus.

Compared to Pa. ruscassierensis n. sp., conspicuous differences have been previously highlighted, particularly in size. The size difference with the genotypic species $\mathrm{Pa}$. duvali, which is one of the smaller species of the genus, is even larger and around $+40 \%$. Furthermore, despite some similarities that lead to bring the two forms closer together in a cladistic analysis (see below), the Aumelas specimens are quite distinct from this latter species by their P2/ even more square, their P3/ P4/ more transversely elongated. So, the Aumelas form can not be considered as affine to Pa. duvali.

In fact, we are dealing with one of the largest Pachynolophus. Assuming that FSL-2977 could be a good representative of Pa. cesserasicus (see above), the specimens of Aumelas are about $15 \%$ larger for most parameters. Conversely, they are $15 \%$ smaller than the type and single specimen of Pa. cayluxi. Besides, compared to both species, the upper molars and mostly the $\mathrm{P} 4 /$ of Aumelas are less bunodont, with ectolophs more flattened. All cingula are thinner and less continuous. P2/ is more quadrangular. Therefore, this Aumelas material probably represents an original new species, but it is too damaged and too poorly known to define a new taxon in the current state.

\section{Genus Lophiotherium Gervais, 1852}

TYPE SPECIES. — Lophiotherium cervulum Gervais, 1852.

INCLUDED SPECIES. - L. siderolithicum (Pictet, 1857); L. pygmaeum (Depéret, 1901); L. robiacense Depéret, 1917, L. sondaari Franzen, 1999.

EMEnded Diagnosis (from Savage et al. 1965). — Small Pachynolophinae of size comparable to Hyracotherium (estimated cranium lengths: 130 to $150 \mathrm{~mm}$ ). Bunodont and rather brachyodont dentition. Upper molars bearing a mesostyle and a strong, discrete paraconule; metaconule more or less connected to hypocone. Trends toward molarization of premolars, with a large intraspecific variability. Except on the more archaic forms, P4/ bearing a hypocone, usually smaller than that of molars. P3/ relatively large and submolariform, lacking however a hypocone but bearing a metaconule. P2/ transversely expanded, with three main cusps, often without metaconule. P1/ mesio-distally elongate showing an incipient development of metacone. Lower cheek teeth with somewhat angular crescents extended by rectilinear cristids. Metaconid usually splitted in two. $\mathrm{P} / 4$, and most often $\mathrm{P} / 3$, molariform, with an entoconid.

\section{Lophiotherium sp.}

(Fig. 11)

Material. - AUM 172, AUM 234 (cast), left M1/; AUM 232 (cast), left (M1/); AUM 1547, left (M2/); AUM 1626, left M2/; AUM 1633, right M3/. AUM 107, right mandible with DP/1$\mathrm{DP} / 4, \mathrm{M} / 1-\mathrm{M} / 2$ and left mandible fragment with $\mathrm{M} / 3$; AUM 170 , left mandible fragment, with DP/2-DP/4, and alveoli of /C and DP/1; AUM 233, right M/1 (cast); AUM 1548, left mandible with (P/4)-M/3; AUM 1550, right $\mathrm{M} / 2$; AUM 1551, right $\mathrm{P} / 3$; AUM 1622, 1624, right $\mathrm{M} / 1$.

\section{DESCRIPTION}

These few specimens document a taxon significantly smaller than the previous ones (Table 5; Fig. 15). The overall stature can be assessed from the fragmentary mandibles AUM 1548 and AUM 107, which leads to evaluate the M/1-M/3 length at $26-28 \mathrm{~mm}$, and might also correspond to a body weight of about $11 \mathrm{~kg}$ (Appendix 8).

The most characteristic pieces are six upper molars, that we attribute to the same taxon in spite of some morphological or/ and size slight differences. These teeth are typified by a marked bunodonty with a moderate crown height, the $\mathrm{I}_{\mathrm{H}}$ being about 0.41 (Appendix 12). The labial cusps are conical and bulbous. The labial side of ectoloph is however rather flat, with marked ribs on paracone and metacone (AUM 234, AUM 1547). The labial cingulum is continuous. The parastyle is high but not very prominent. The development of mesostyle appears inconstant: strong, bulbous at the neck and confused in the ectocingulum (AUM 172, AUM 232 and AUM 234), weak and/or not connected to cingulum (AUM 1547 and AUM 1626), and even missing (AUM 1633). The well individualized paraconule, slightly lower than the protocone, is usually isolated by a deep groove, except on AUM 1547 where the groove is shallower.

The protoloph is directed towards parastyle, but it vanishes before reaching ectoloph. The metaconule is low, elongated and fairly separated from hypocone. The disto-lingual angle of the tooth is somewhat receded (AUM-234). The lingual cingulum of this tooth is thin but uninterrupted up to the fairly marked mesial and distal cingula.

As for lower cheek teeth, M/1 and M/2 are typified by their bunodonty with lingual cuspids more bulbous and higher than labial ones. The crescentic labial cuspids are extended by rectilinear cristids (slightly more rounded on AUM 1622). The oblique paracristid reaches the mesial cingulum without any distinct paraconid. The trigonid is very short on AUM 233 and the metaconid is clearly split, yet less noticeably on the molars of AUM 107. The transverse cristids (protolophid and hypolophid) are almost perpendicular to longitudinal tooth axis. The hypoconulid is only slightly protruding. The labial cingulid is more or less continuous and thin, even almost missing on AUM 1548. There is no lingual cingulid.

Only one premolar is known in the sample and is interpreted as a rather worn P/3 (AUM 1551). It is apparently less bulbous than molars and tapers slightly mesially. The talonid is indeed slightly wider than the trigonid, which is crescentiform and broadly open on lingual side. The paracristid ends in a small 
TABLE 5. - Dental measurements (in mm) of cheek teeth of Lophiotherium sp. from Aumelas. Parameters: see able 1. For individual data, see Appendix 7.

Lophiotherium sp. from Aumelas

\begin{tabular}{|c|c|c|c|c|c|c|c|c|c|c|c|c|}
\hline & \multicolumn{4}{|c|}{ M1/ } & \multicolumn{4}{|c|}{ M2/ } & \multicolumn{4}{|c|}{ M3/ } \\
\hline & $\mathbf{L}$ & w & D & d & L & w & D & d & L & w & D & d \\
\hline $\begin{array}{l}\mathrm{N} \\
\text { mean }\end{array}$ & $\begin{array}{l}2 \\
6.9\end{array}$ & $\begin{array}{l}2 \\
8.1\end{array}$ & $\begin{array}{l}2 \\
8.6\end{array}$ & $\begin{array}{l}3 \\
7.9\end{array}$ & $\begin{array}{l}1 \\
7.6\end{array}$ & - & - & $\begin{array}{l}2 \\
9.7\end{array}$ & $\begin{array}{l}1 \\
9.9\end{array}$ & $\begin{array}{l}1 \\
9.6\end{array}$ & $\begin{array}{c}1 \\
11.6\end{array}$ & $\begin{array}{l}1 \\
9.5\end{array}$ \\
\hline variation range & $6.8-6.9$ & $7.6-8.6$ & $8.1-9.1$ & $7.6-8.2$ & - & - & - & $9.7-9.7$ & - & - & - & - \\
\hline $\begin{array}{l}\text { standard } \\
\text { deviation }\end{array}$ & - & - & - & 0.306 & - & - & - & - & - & - & - & - \\
\hline $\begin{array}{l}\text { coeff. of } \\
\text { variation }\end{array}$ & - & - & - & 3.9 & - & - & - & - & - & - & - & - \\
\hline
\end{tabular}

\begin{tabular}{|c|c|c|c|c|c|c|c|c|c|c|c|c|c|c|c|c|}
\hline & \multicolumn{3}{|c|}{$\mathrm{P} / 3$} & \multicolumn{3}{|c|}{$\mathrm{P} / 4$} & \multicolumn{3}{|c|}{ M/1 } & \multicolumn{3}{|c|}{$M / 2$} & \multicolumn{4}{|c|}{$M / 3$} \\
\hline & L & W1 & W2 & $\mathbf{L}$ & W1 & W2 & $\mathbf{L}$ & W1 & W2 & $\mathbf{L}$ & W1 & W2 & $\mathbf{L}$ & W1 & W2 & W3 \\
\hline $\mathrm{N}$ & 1 & 1 & 1 & - & - & 1 & 5 & 4 & 4 & 3 & 2 & 2 & 2 & 2 & 1 & 1 \\
\hline mean & 7.0 & 3.7 & 4.1 & - & - & 4.3 & 7.5 & 4.8 & 5.1 & 8.0 & 5.2 & 5.3 & 11.7 & 5.8 & 5.0 & 4.1 \\
\hline variation range & - & - & - & - & - & - & $7.0-8.0$ & $4.5-4.9$ & $4.8-5.0$ & $7.7-7.9$ & $4.5-5.8$ & $4.8-5.8$ & $\begin{array}{c}11.2 \\
12.2\end{array}$ & $5.6-5.9$ & - & - \\
\hline $\begin{array}{l}\text { standard } \\
\text { deviation }\end{array}$ & - & - & - & - & - & - & 0.430 & 0.216 & 0.252 & 0.361 & - & - & - & - & - & - \\
\hline $\begin{array}{l}\text { coeff. of } \\
\text { variation }\end{array}$ & - & - & - & - & - & - & 5.7 & 4.5 & 5.0 & 4.5 & - & - & - & - & - & - \\
\hline
\end{tabular}

\begin{tabular}{|c|c|c|c|c|c|c|c|c|c|}
\hline & \multicolumn{3}{|c|}{$\mathrm{DP} / 2$} & \multicolumn{3}{|c|}{$\mathrm{DP} / 3$} & \multicolumn{3}{|c|}{ DP/4 } \\
\hline & L & W1 & W2 & L & W1 & W2 & L & W1 & W2 \\
\hline $\begin{array}{l}\mathrm{N} \\
\text { mean }\end{array}$ & $\begin{array}{l}2 \\
5.4\end{array}$ & $\begin{array}{l}- \\
-\end{array}$ & $\begin{array}{l}2 \\
2.9\end{array}$ & $\begin{array}{l}2 \\
7.3\end{array}$ & $\begin{array}{l}2 \\
3.5\end{array}$ & $\begin{array}{l}2 \\
4.0\end{array}$ & $\begin{array}{l}2 \\
6.9\end{array}$ & $\begin{array}{l}1 \\
4.2\end{array}$ & $\begin{array}{l}1 \\
4.5\end{array}$ \\
\hline $\begin{array}{c}\text { variation } \\
\text { range }\end{array}$ & $5.2-5.6$ & - & $2.8-2.9$ & 7.2-7.3 & 3.3-3.7 & $3.8-4.2$ & $6.6-7.2$ & - & - \\
\hline
\end{tabular}

and low paraconid, reaching the anterior cingulum in lingual position. A wide wear facet unites the protolophid with the disto-labial ridge of the protoconid. The metaconid is clearly split. The talonid is lower than the trigonid. The metalophid, which originates at the base of the metaconid, leads to a low and rather labial hypoconid. There is no entoconid. The ectocingulum vanishes on the protoconid. There is no lingual cingulid.

The deciduous lower dentition is known from two mandibles (AUM 107, AUM 170). The DP/4 are molariform. The DP/4 of AUM 170 is very bunodont and its metaconid is clearly split. The hypoconulid is prominent on AUM 107. The DP/3 are also almost molariform, but very elongated, and tapering rostrally. The crescent of its trigonid is flattened and widely opened lingually. The paracristid ends with a rather large but low paraconid. The $\mathrm{DP} / 2$ is narrow and orally tapering. The main cuspid is preceded by a small tubercle and distally extended by a labial and a lingual ridges. The talonid is wide, short, and raised by a low parasagittal cristid. The cingulids of these teeth (labial, anterior and posterior) are better marked than on permanent molars. The DP/1 (AUM 107) is a small monocuspid, bi-rooted and slightly distally enlarged tooth.

The mandible body height varies from $18.5 \mathrm{~mm}$ under the $\mathrm{P} / 3-\mathrm{P} / 4$ limit to $22.5 \mathrm{~mm}$ under the $\mathrm{M} / 3$ protoconid. The condyle is rather short $(12.7 \times 5.7 \mathrm{~mm})$ and is mesio-distally and slightly ventrally slanted. The angular process is mainly developed caudally and the ramus is not very high, the condyle being only $17.5 \mathrm{~mm}$ above the occlusal plane of teeth (AUM 1548). The temporal-masseter ratio (MMT/MMM; 23/48.5) does not exceed 47.4, indicating a rather high development of the masseter suggesting a more derived condition than in L. pygmaeum (Appendix 19; Fig. 6).On the juvenile mandible (AUM 170), the DPC appears to have been short, probably about $20 \%$ of LRDJ according to length of the deciduous teeth series. Two mental foramina are visible on AUM 170, one under the DPC and the second below the P/1-P/2 limit. The body of the mandible (AUM 107) exhibits a regular height without noticeable caudal increase, and the vertical ramus was probably not high but rather wide.

\section{COMMENTS}

The assignment of these specimens to the genus Lophiotherium is based on their small size, the presence of mesostyles on some upper molars and above all on their strong bunodonty, which differentiates them from Eurohippus. The only difficulty concerning this assignment is the short post canine diastema on AUM 170, whereas this genus is precisely characterized by exceedingly long DPCs. But this shortness can be attributed to the youthful character of the individual in question.

The Lophiotherium species are hardly differentiable between each other on the basis of size. The variation ranges of measures are greatly overlapping. The material from Aumelas appears somewhat smaller than $L$. robiacense and $L$. cervulum, about the same size than L. siderolithicum and L. pygmaeum, and also probably than L. sondaari according to the data of Franzen (1999). but most of size differences with these species are not statistically significant, because the Aumelas' sample is too small (Appendices 23; 24). 
A2

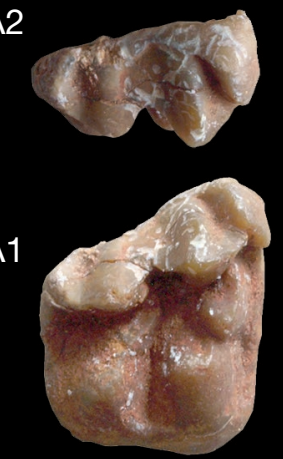

G

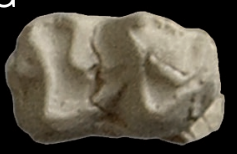

B

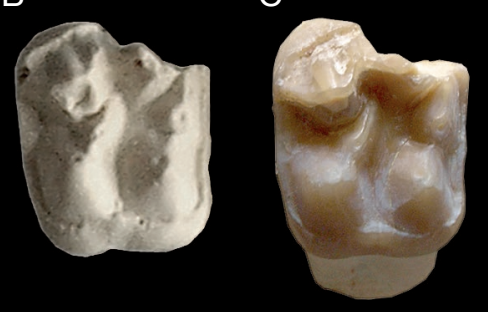

D

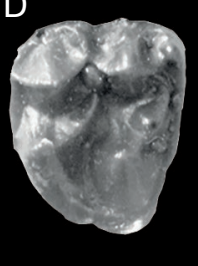

A-I
E

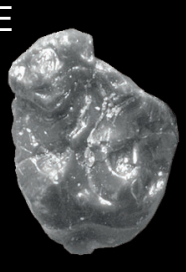

F

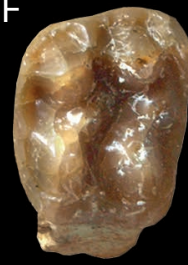

I
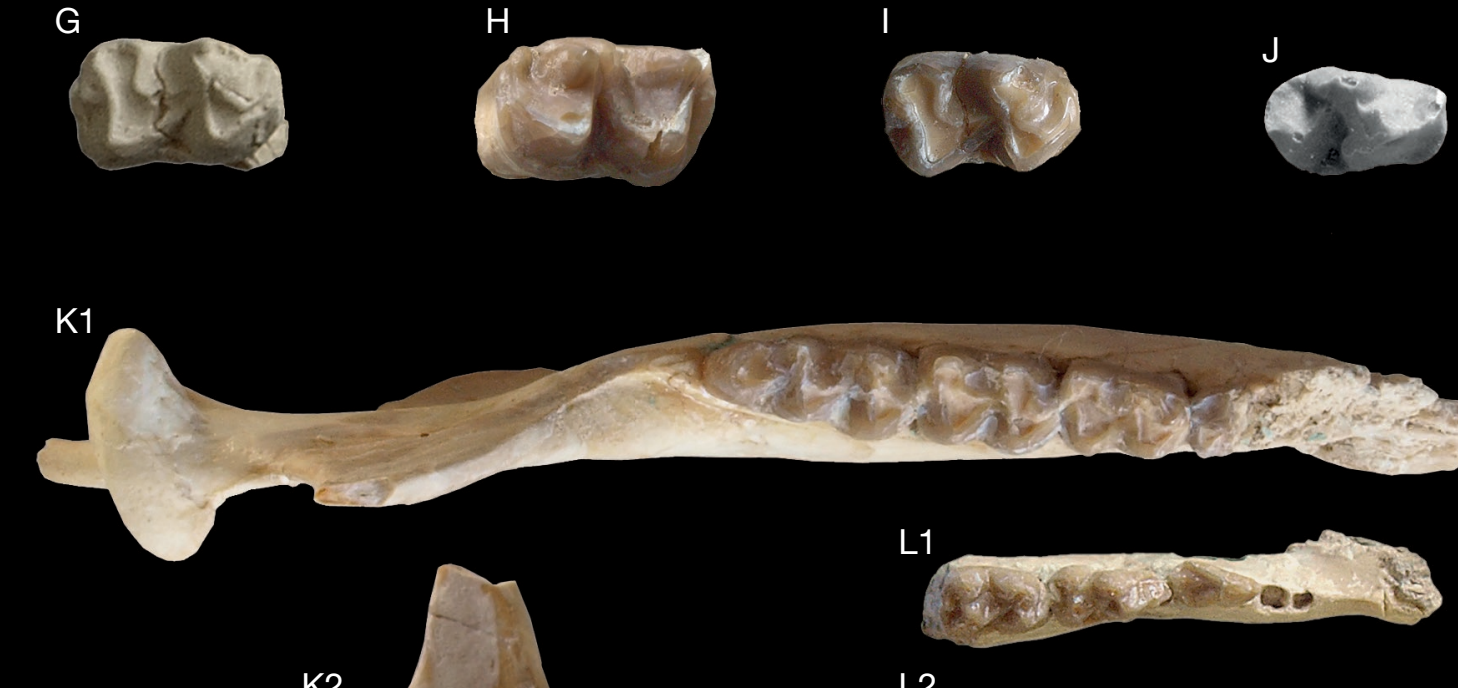

L1

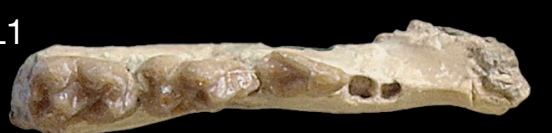

L2

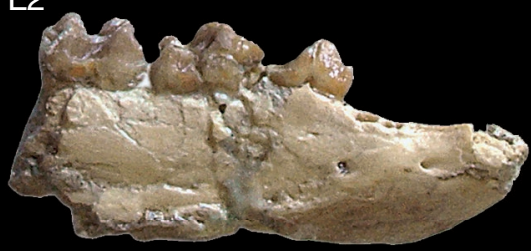

K, L
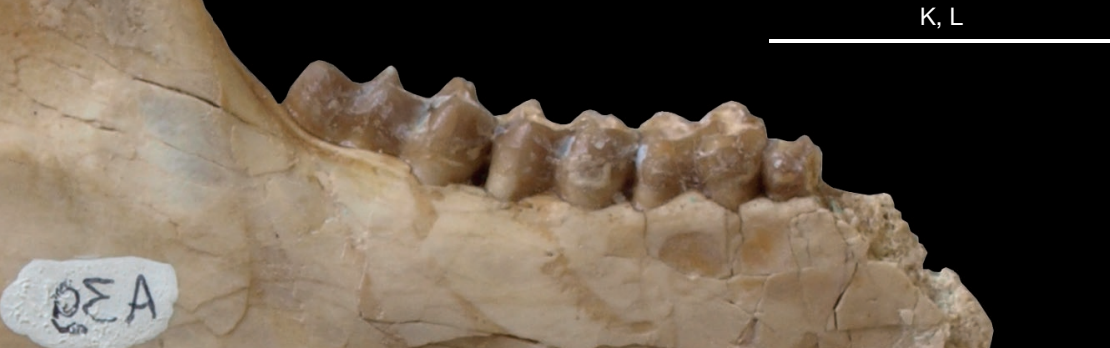

$\operatorname{lin}_{2}$

FIG. 11. - Lophiotherium sp. from Aumelas: A, AUM 1633, right M3/; A1, occlusal view; A2, labial view; B, AUM 1547, left M2 (reversed), occlusal view; C, AUM 1626, left M2/ (reversed), occlusal view; D, AUM 234, right M1/, occlusal view (cast); E, AUM 232, left M1/ (reversed), occlusal view (cast); F, AUM 172, left M1/ (reversed), occlusal view; G, AUM 1550, right M/2, occlusal view (cast); H, AUM 1622, left M/1 (reversed), occlusal view; I, AUM 1624, right M/1, occlusal view; J, AUM 1551, right P/3, occlusal view (cast); K, AUM 1548, left mandible with (P/4)-M/1-M/3 (reversed); K1, occlusal view; K2, labial view; L, AUM 170, left mandible fragment with (alv. DP/1)-DP/2-DP/4 (reversed); L1, occlusal view; L2, labial view. Scale bars: $2 \mathrm{~cm}$. 


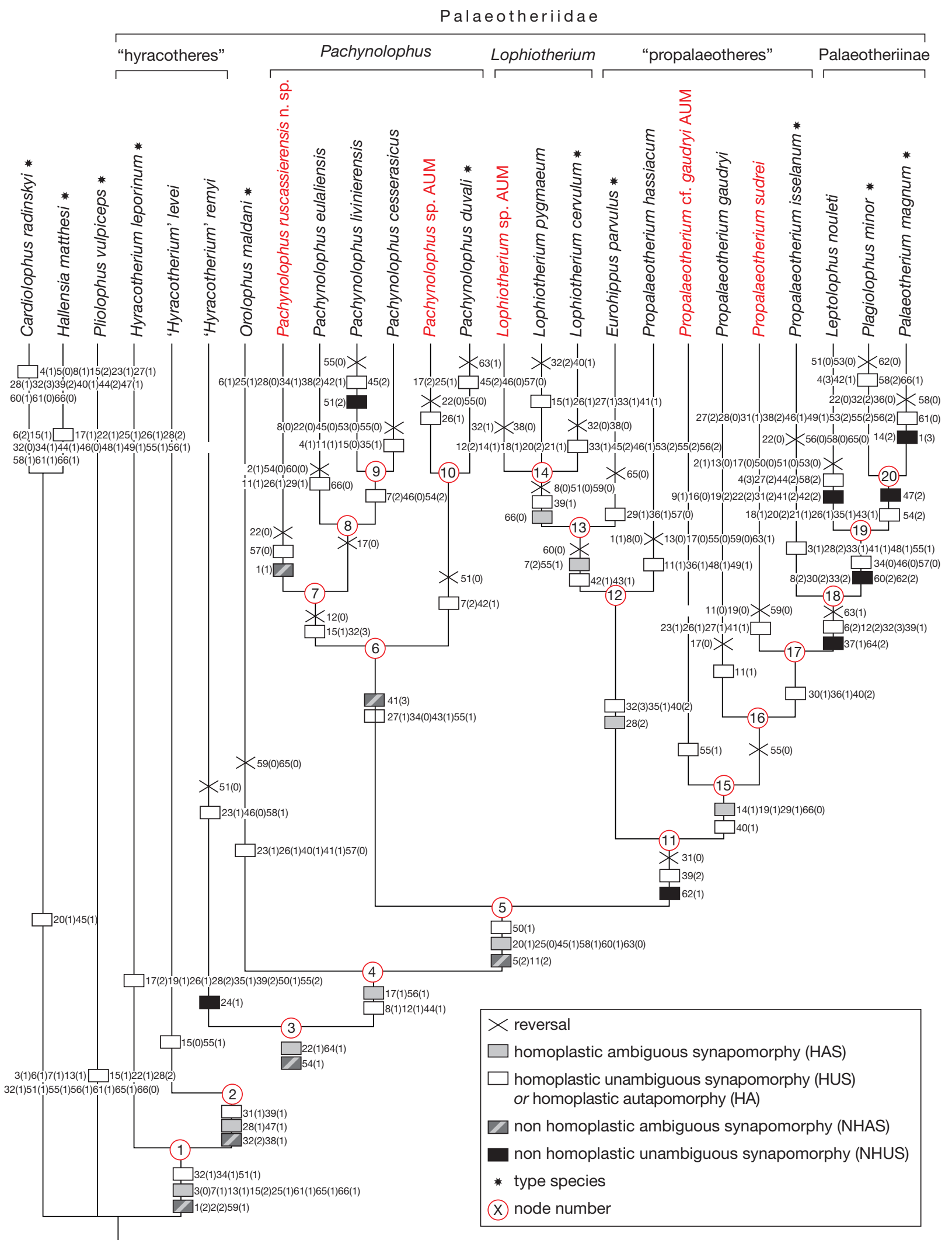

FIG. 12. - Strict consensus of the two trees of the cladistic analysis. "Hyracotheres" are included in the Palaeotheriidae according to Remy, 2017. The taxa recognized at Aumelas are mentioned in red. 
The upper molars of $L$. sondaari appears to be even more brachyodont and bunodont than those of Aumelas, with a low, W-shaped ectoloph, due to very strong mesostyles. The enamel is apparently thicker and a broad cingulum completely surrounds all teeth. Those of Aumelas have a distinctly less archaic appearance, with higher and flatter ectolophs, higher parastyles, and less surrounding cingula. Conversely, they bear less prominent and even inconstant mesostyles. Unfortunately, the lower cheek teeth of this Geiseltal' species are not known. In any case, the form of Aumelas clearly cannot be assigned to this species.

Similarly, L. robiacense and L. cervulum are characterized by a notably higher degree of bunodonty than on the material from Aumelas. Besides, all species of Lophiotherium distinguish mainly by the degree of molarization of premolars. Unfortunately, the upper ones are unknown at Aumelas. We are therefore also unable to compare the relative surfaces of the premolars series, which would have provided a good argument to differentiate them from L. pygmaeum or L. siderolithicum (Remy 2015). Only one P/3 (AUM 1551) and the milk molars of the mandibles AUM107 and AUM170 are available for comparison. Compared to L. pygmaeum, these teeth exhibit archaic features: $\mathrm{P} / 3$ lacking an entoconid, DP/2 bearing a short talonid with only a rectilinear ridge. But these characters are known as variable within a single species (Stehlin 1905), making isolated observations not actually significant.

Variations in the degree of bunodonty, development of mesostyle and splitting of metaconid are noted on the Aumelas material and similar variations can also be observed in $L$. pygmaeum or L. siderolithicum (Stehlin 1905; Hooker \& Weidmann 2000). For instance, at Egerkingen, the bunodonty is more or less accentuated: the labial cusps of upper molars may be very conical and the external wall almost missing (e.g. NMB Eb-78, Eh-356), or, on the contrary, these cusps can form a labially flattened ectoloph (NMB Eb-2, Eb-244). Likewise, the molar mesostyles are variously thick (e.g. weak on NMB Eb-394 and globular on NMB Eb-73 and Eb-358). The protoloph groove can be deep (NMB Eb-18, Eb-73, Eb-244, Eb-282) or shallow (NMB Eb-16, Eb-31, Eb-75). Finally, the splitting of the metaconid is highly accentuated (NMB Ec-139) or barely visible (NMB Ec-90).

Finally, in the context of large variability known in all Lophiotherium species, and failing dimensional or morphological, decisive criteria, it is not possible to propose a specific determination for the very scarce sample of teeth from Aumelas.

\section{CLADISTIC ANALYSIS}

A cladistic analysis was carried out based on a recently published one (Remy 2017) with the adjunction of the Aumelas taxa described herein. The same character list has been retained, but six modifications have been brought to this matrix (Remy 2017), based on additional data. These are the following: character 17: Hyracotherium leporinum $0 \rightarrow 2$, Pachynolophus duvali $1 \rightarrow 2$, Pa. livinierensis $1 \rightarrow 0$; character 31: Cardiolophus radinskyi $2 \rightarrow 0$; character 65: Propalaeotherium gaudryi $0 \rightarrow 1$, Pachynolophus eulaliensis $0 \rightarrow 1$. However, it has been
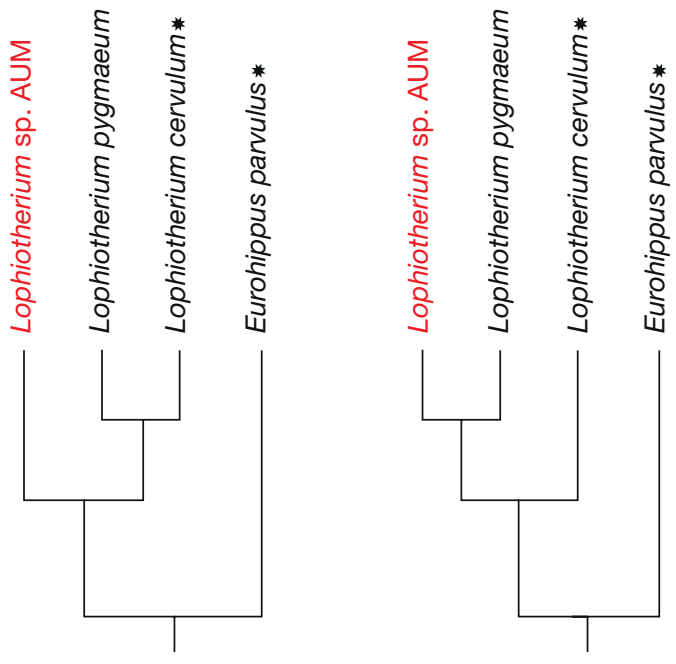

FIG. 13. - Unresolved position of Lophiotherium sp. from Aumelas in the cladistic analysis.

ascertained that these changes have no impact on the topology of the already published tree (Remy 2017). In this way, the new matrix still gathers 66 unweighted cranial and dental characters but scored now for 25 taxa (Appendices 1;2).

The analysis was performed with PAUP $4.0 \mathrm{~b} .10$ by means of a heuristic search with 1000 random replications, random stepwise addition procedure and default values for other PAUP parameters. Two most parsimonious trees were generated, the consensus of which is illustrated on Figure 12. Both trees score a length of 286 steps $(\mathrm{CI}=0.36$ and $\mathrm{RI}=0.53)$. Twenty nodes are recognized in the distribution of the ingroup taxa, seven of them have only a weak Bremer Index $(\mathrm{BI}=1)$, but the others are stronger (eight $\mathrm{BI}=2$, five $=3$ to 8 ).

\section{DESCRIPTION}

The topology of the most parsimonious trees is barely modified by incorporation of the Aumelas taxa, although several nodes are obviously added. The only significant change, induced by these adjunctions, concerns Orolophus maldani, which is no longer positioned between Pachynolophus and propalaeotheres, but at the basis of this set, hence closer to the hyracotheres. It remains however separated from them and gathered with all other palaeotheriids (node 4) by three homoplastic unambiguous synapomorphies (HUS) (8[1], buno-lophodont dentition; 12[1], somewhat quadrangular P2/ but with a slanted mesial side; 44[1], not continuous lingual cingulum on upper molars) and two homoplastic ambiguous synapomorphies (HAS) (17[1], conspicuous metaconule on P3/, more or less separated from the protocone; 56[1], incipient entoconid on $\mathrm{P} / 4$ ). Moreover, Orolophus maldani is distinguished by five homoplastic autapomorphies (HA) (23 [1], distal expansion of posterolingual cingulum on P4/; 26[1], mesially shifted protocone of $\mathrm{P} 4 / ; 40[1]$, occasional upper molar mesostyle; 41[1], upper molar mesostyle strong but separated from ectocingulum; 57[0], narrow lower molars) and two reversals (59[0], protolophid and hypolophid transversally arranged on lower molars; 65[0], accessory crest missing on $\mathrm{M} / 3$ ). 
TABLE 6. - Repartition of dental features of the palaeotheriid taxa of Aumelas. Abbreviations: UM, upper molars; LM, lower molars; 1, from small (light color squares) to large (darkest squares); 2, from rather low (light color) to rather high (dark color); $\mathbf{3}$, from absent (light) to constant (dark); $\mathbf{4}$, from weak (light) to strong (dark); 5, from interrupted (light) to continuous (dark); 6, from centred (light) to displaced (dark); 7, from narrow (light) to broad (dark); 8, from rounded (light) to sharp (dark).

Propalaeotherium sudrei Remy, Krasovec \& Marandat, 2016 Propalaeotherium cf. gaudryi

Pachynolophus ruscassierensis n. sp.

Pachynolophus sp.

Lophiotherium sp.

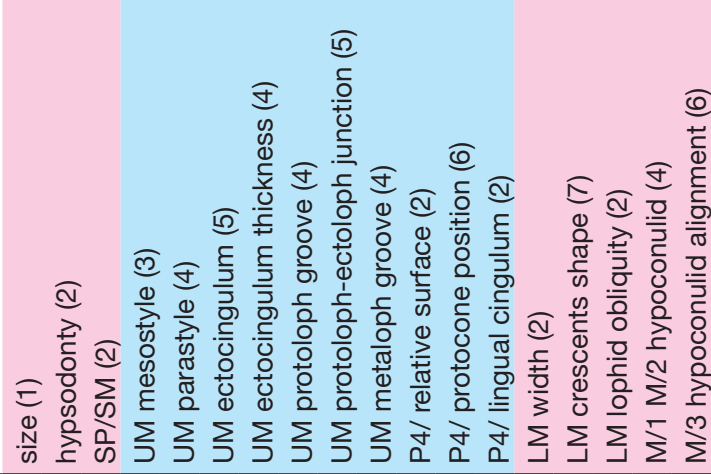

The systematic position of the other taxa involved in the analysis performed by Remy (2017) remains unchanged and has already been thoroughly described. Therefore, the under coming new description will essentially concerned phylogenetic relationships of the new introduced taxa.

\section{Node 7}

The node 7 gathering Pachynolophus ruscassierensis $\mathrm{n}$. sp. with some other Pachynolophus is sustained by two HUS (15 [1], incomplete postprotocrista on P3/; 32[3], lacking metaloph grooves on upper molars) and one reversal (12[0], triangular P2/, tapering forward). At this level, Pachynolophus ruscassierensis $\mathrm{n}$. $\mathrm{sp}$. is characterized by one non homoplastic ambiguous synapomorphy $(1[1]$, nasal notch ending above the DPC, close to the canine), one HA (57[0], narrow lower molars) and one reversal (22[0], strong and continuous lingual cingulum on $\mathrm{P} 4 /$ ), opposite to the other Pachynolophus species which retain one reversal (17[0], indistinct metaconule on $\mathrm{P} 3 /)$.

\section{Node 10}

The node 10, which gathers Pachynolophus sp. from Aumelas and Pachynolophus duvali associates two HUS (7[2], long postcanine diastemata; 42[1], upper molar ectocingulum usually interrupted on the paracone). Pachynolophus sp. from Aumelas distinguishes by one HA (26[1], mesially shifted protocone of $\mathrm{P} 4 /)$ and two reversals (22[0], strong and continuous lingual cingulum on $\mathrm{P} 4 / ; 55[0]$, low relative surface of $\mathrm{P} 4 /$ ).

\section{Node 14}

The node 14 includes all the considered Lophiotherium species in one clade. It is characterized by one HAS (66[0], hypoconulid of M/3 in labial position), one HUS (39[1], high but not protruding parastyle on upper molars) and three reversals (8[0], very bunodont dentition; 51[0], convex distal outline of M3/; 59[0] protolophid and hypolophid transversally arranged on lower molars). The Lophiotherium sp. from Aumelas distin- guishes from the other Lophiotherium species by two reversals (32[1], average upper molar metaloph groove; 38[0], strong metacone labial ripple on upper molars).

\section{Node 15}

The node 15 uniting Propalaeotherium cf. gaudryi from Aumelas and Pr. gaudryi to the clade leading to the Palaeotheriinae is characterized by one HUS (40[1], occasional mesostyle on upper molars) and three HAS (14[1], incomplete molarization of $\mathrm{P} 2 / ; 19[1]$, accessory crest on the protocone of $\mathrm{P} 3 /-\mathrm{P} 4 /$; 29[1], metaconule of $\mathrm{P} 4 /$ possibly distal to the postprotocrista). At this level, Propalaeotherium cf. gaudryi is distinguished from Pr. gaudryi by a greater relative surface of $\mathrm{P} 4 /$ (55[1] instead of 55[0]), which untimely positions this taxon in a less derived position on the tree contrary to above mentioned considerations (see page 537).

\section{Node 17}

The node 17 connecting Propalaeotherium sudrei to Pr. isselanum and to the Palaeotheriinae is characterized by three HUS (30[1], average cheek teeth crown height; 36[1], upper molar metaloph-ectoloph junction towards the centrocrista; 40[2], constant upper molar mesostyle). Finally, Propalaeotherium sudrei is individualized at this level as associating four HUS (23 [1], distal expansion of the posterolingual cingulum of P4/; 26[1], mesially shifted protocone of P4/; 27[1], moderately large paraconule on $\mathrm{P} 4 / ; 41$ [1], upper molar mesostyle strong but separated from ectocingulum) with three reversals (11[0], presence of a post-P1 diastema; 19[0], accessory distal crest lacking on the protocone of $\mathrm{P} 3 /-\mathrm{P} 4 / ; 59[0]$, protolophid and hypolophid transversally arranged on lower molars).

\section{COMments}

The addition of Aumelas' species in the matrix of Remy (2017) does not introduce fundamental changes in the distribution of taxa. The amended position of Orolophus maldani, is associ- 


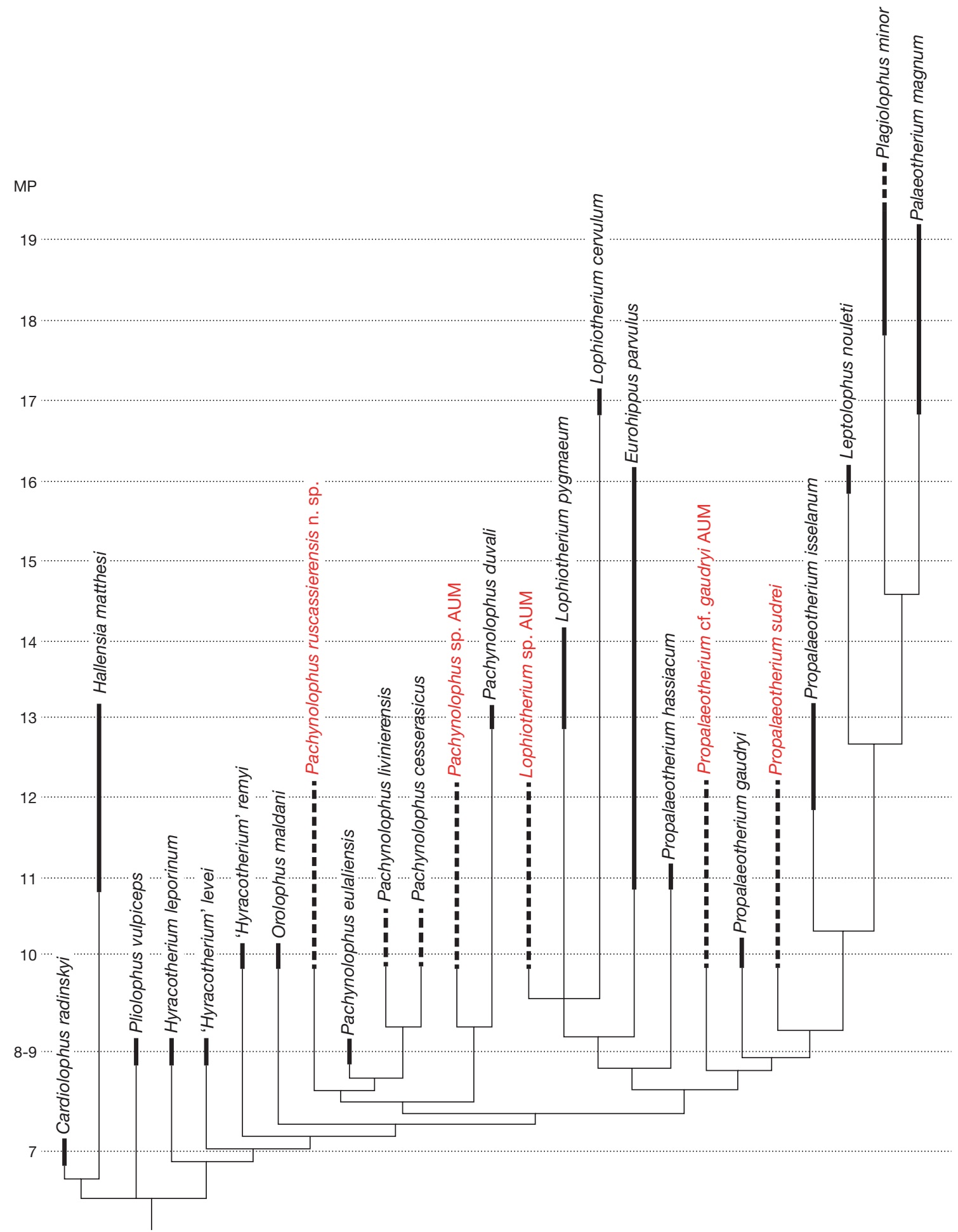

FIG. 14. - Consensus tree of parsimonious analysis adjusted to the biochronological scale. Pachynolophus livinierensis (and consequently Pa. cesserasicus), formerly assigned to the MP 15 level is now better located in the interval MP 10-11 (Comte et al. 2012; Godinot et al. 2018). The dashed lines indicate the undetermined dating range of some taxa. For Plagiolophus minor, they symbolize the presence of the species beyond MP 19 (up to MP 22).

ated to a low index of Bremer (node 3), as in the preceding analysis (Remy 2017), partly due to the scanty documentation of the neighbouring hyracotheres, " $H$ " levei and " $H$ " remyi. We have seen nevertheless, that the new genus is supported by a fairly great number of apomorphies that justify its validity.
Besides, the analysis confirms the systematic attributions of the palaeotheriid taxa from Aumelas, by their individual localization on the parsimonious trees. Pachynolophus ruscassierensis n. sp., apparently less derived than Pa. eulaliensis, occupies a very basal position among Pachynolophus species. 


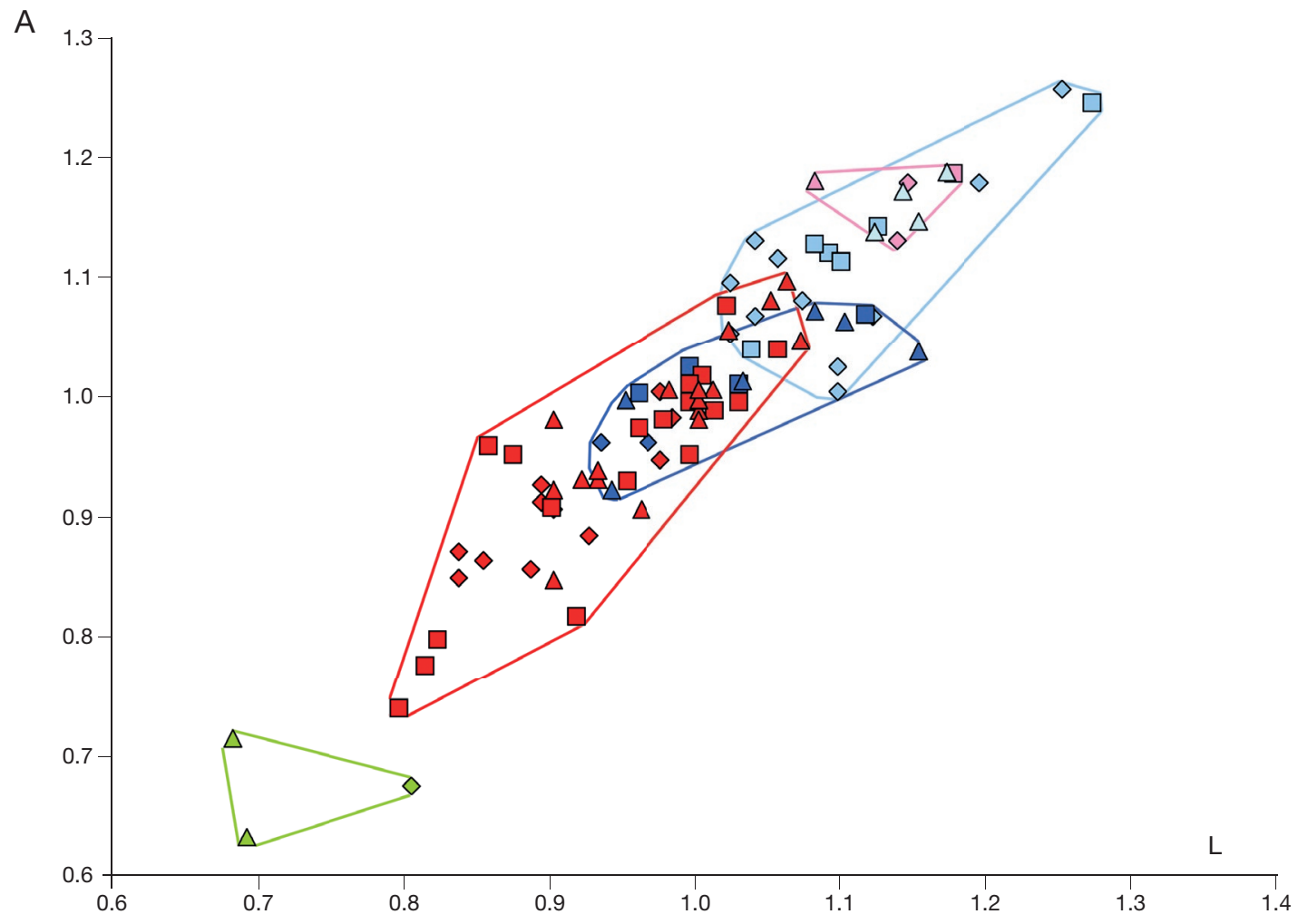

B

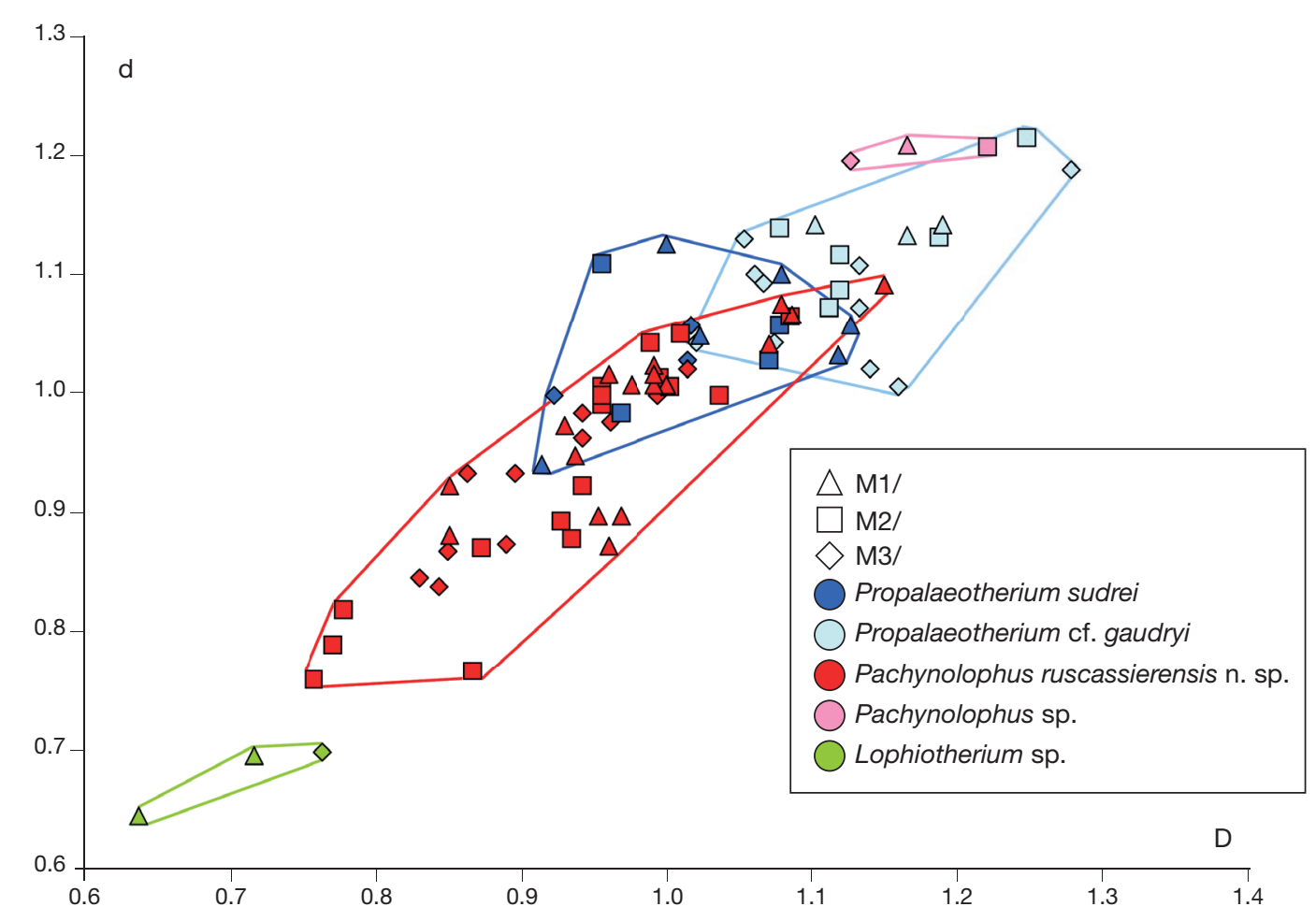

FIG. 15. - Bivariate chart of upper molars dimensionless measures of Aumelas' Palaeotheriidae.(measurements of each specimen reported to the overall average of the whole sample for its tooth rank). See text and Figure 2 for definition of parameters. These graphs allow representing variations of size of all upper molars of the whole sample in a synthetic way. 
Pachynolophus sp. appears to be close to $\mathrm{Pa}$. duvali but, as already discussed, it is a too scarcely documented form to conclude on this phylogenetic position.

In the current state, the taxon Propalaeotherium cf. gaudryi appears less derived than its referred species. Nevertheless, a more important material would perhaps allow to assimilate it completely to this species. In the group leading to the Palaeotheriinae, Propalaeotherium sudrei retains the same position as in the previous analysis, i.e. less derived than Pr. isselanum.

The position of Lophiotherium sp. is ambiguous with respect to the other two species of the genus here considered. The two trees of the analysis only differ in the distribution inside the Lophiotherium clade (Fig. 13). This irresolution is related to a bad documentation of the Aumelas form, characterized only by 2 reversals. On the first tree, it is in an archaic position. On the second one, conversely, L. cervulum appears as the least derived, perhaps because of reinforcement of the bunodonty, which characterizes this species $(32[0]$ and 38[0]).

In conclusion, this parsimony analysis highlights and confirms the essentially archaic character of the palaeotheriids of Aumelas.

\section{DISCUSSION AND CONCLUSION}

CONSIDERATIONS ON THE AVAILABLE SAMPLE OF EQUOIDEA The available material of Equoidea of the Aumelas fauna consists essentially of isolated cheek teeth or teeth series, with scarce cranial or mandibular elements. The post-cranial skeleton is not documented. There are apparently no ontogenetic bias, young individuals (e.g. AUM 182, 1618) as well as very old specimens (e.g. AUM 1586, 199, 138) being represented. While the material is somewhat crumbled, there is no trace of rolling; the pieces must have been dislocated on site or nearby.

Five species of Palaeotheriidae are reported, which are only "Pachynolophinae" excluding any Palaeotheriinae. Apart from the teeth that have been attributed to the genus Lophiotherium on the basis of their bunodonty and very small size, the differentiation between both other genera was based primarily on the presence or absence of mesostyles on upper molars, but also on several characters notably of the ectoloph, protoloph, cingula, or on the shape of crescents of lower molars. The specific assignment was done from size and various peculiarities $\mathrm{A}$ synthetic chart (Table 6) resumes these main distinctive features.

All were animals of a rather small size, ranging from an estimate average weight of $11 \mathrm{~kg}$ (for Lophiotherium sp.) to $34 \mathrm{~kg}$ (for Propalaeotherium cf. gaudryi) (Appendix 8). The size variation of upper molars is illustrated in Figure 15.

With a sample of about 180 specimens, the distribution and relative abundance of the various species is illustrated on Figure 16. The prominent form is the new species of Pachynolophus, $\mathrm{Pa}$. ruscassierensis n. sp., summing almost $41 \%$ of the whole sample. It is followed in term of abundance by Propalaeotherium sudrei with $26 \%$ of the specimens. The other three forms are less documented, not known enough to define their specific status. The least recorded species is the small Lophiotherium sp.

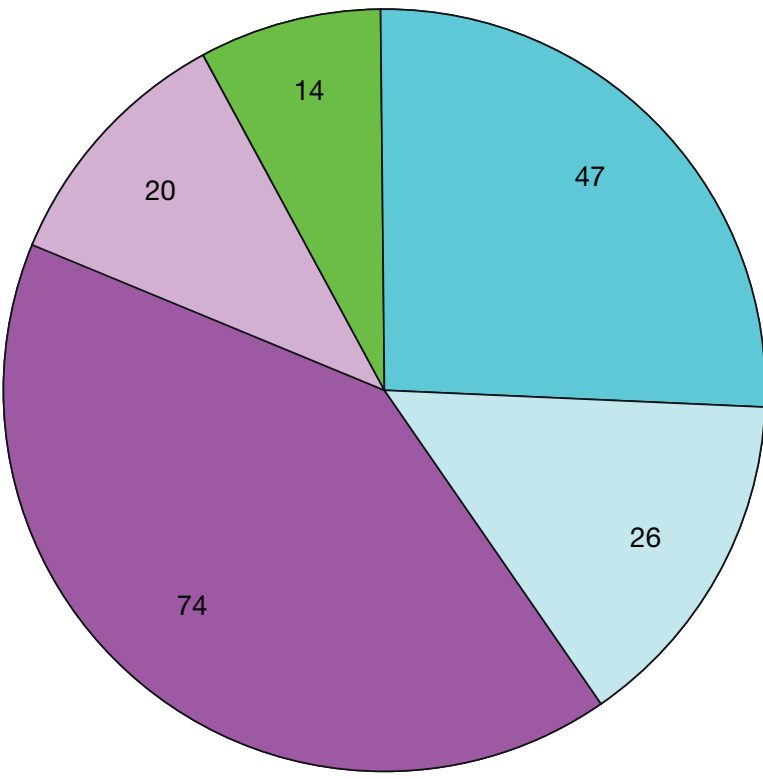

Propalaeotherium sudrei

Propalaeotherium cf. gaudryi

Pachynolophus ruscassierensis $\mathrm{n}$. sp.

Pachynolophus sp.

Lophiotherium sp.

FIG. 16. - Number of specimens and systematic distribution of the Aumelas' Palaeotheriidae.

\section{BIOCHRONOLOGICAL INFERENCES}

Until now, several papers would tend to attribute to the fauna of Aumelas a biochronological age close to the reference level MP 13 (Geiseltal oMK), or even a little younger. Hartenberger (1963) concluded that the locality belonged to the Upper Lutetian, and in 1969 Hartenberger et al. parallelized it with Issel and Bouxwiller (the latter site itself equivalent to the Calcaire Grossier supérieur of the Parisian Basin [Hartenberger 1973]). On the basis of artiodactyls (including the new genus Aumelasia) and an adapid primate (Anchomomys), Sudre (1980) positioned the locality above the Calcaire Grossier supérieur, between Bouxwiller and Egerkingen. Godinot (1988) on the ground of the Anchomomys, considered the fauna of Aumelas as intermediate between those of Egerkingen-Huppersand and Lissieu, so perhaps even a little more recent than assumed by Sudre (1980). Escarguel et al. (1997) also considered the fauna close to the MP 13, assuming an age of 43.4 MA (from the same primate and artiodactyls), which they estimate as equivalent to the upper levels of the Geiseltal oMK and to the site of Bouxwiller. Escarguel (1999) specified this supposed dating by locating the Aumelas deposit between Bouxwiller and Egerkingen $\alpha, \beta$. At last, Maitre et al. (2008), also parallelized the Aumelas fauna with MP 13 level based on Amphilemuridae.

However, this generally accepted opinion is after all based only on unconvincing arguments because they are only based 
on a few and scarce original specimens. Moreover, occurrence of Aumelasia gabineaudi at Messel (Franzen 1988), type-locality of MP 11 level (Franzen \& Haubold 1986b) leaves doubt on the dating. Therefore, on the BiochroM'97 synthetic chart (BiochroM'1997, tab.3, p.781), the Aumelas deposit remains mentioned as equivalent to Geiseltal oMK but with a question mark.

Therefore, there is a prominent interest to note that the Equoid material of Aumelas provides some new clues to date the locality, although the genera Pachynolophus, Propalaeotherium and Lophiotherium are known respectively from MP 8-9, 10, 11 (Danilo et al. 2013; Remy 2017; Franzen 1999) to MP 17 (BiochroM'97). Since it is a new species, Pachynolophus ruscassierensis n. sp. gives no direct chronologic indication but many features justifying its position in the cladistic analysis highlights that it is a rather archaic species (shallow nasal notch, relatively thick and high cingula, rather small and triangular P2/, not greatly reduced surface of the premolar area, labial crest of hypoconulid of $\mathrm{M} / 3$ connected to the middle of the hypolophid). Furthermore, the presence of a form directly related to Propalaeotherium gaudryi is also an archaic indication. Elsewhere, Propalaeotherium sudrei, appearing near the base of the lineage leading to the Palaeotheriinae, is also less derived than Pr. isselanum (MP 12-13), although a little more than Pr. voigti (MP 11-13). This latter is nevertheless likely pertaining to another lineage. Pachynolophus sp. and Lophiotherium sp. are too poorly represented to give convincing arguments of dating.

It should also be remembered that the Palaeotheriinae, very diversified at MP 14 level (Egerkingen $\alpha, \beta$ ) already appear in deposits close to MP 13 (Bouxwiller, Geiseltal OHM, Jumencourt, Château-Thierry, La Défense) (Stehlin 1904: 351 sq.; Ginsburg et al. 1977; Franzen \& Haubold 1986a) and perhaps even close to MP 12 (Geiseltal uMK, Hellmund 2000). Although it is a negative argument, it should be emphasized that up to now Palaeotheriinae are totally missing in the Aumelas fauna.

Finally, it seems difficult to attribute to the fauna of Aumelas, on the basis of Equoidea, an age close to MP 13 level. The set of concordant considerations here gathered leads to think that this fauna is certainly older than the opinion so far accepted. It should likely be assigned to a level between MP 10 and MP 12. This age could perhaps be close to that of Rouzilhac, due to the common presence of a form related to Propalaeotherium gaudryi, which is however, concerning the Equoidea, the only point of convergence of both faunas. This conclusion is highlighted on Figure 14, where the consensus tree is parallelized with the biochronologic scale. Other mammalian groups such as creodonts would apparently lead to similar conclusions (Solé pers. comm.)

There are, therefore, significant discrepancies with the observations made previously by the above-mentioned authors and with the conclusions they reached. The question needs to be thoroughly processed. It will be considered in a more extensive paper involving specialists of all concerned mammalian and reptile orders.

\section{Acknowledgements}

We are first grateful to Dr Dominique Vidalenc who put one of us (EL) in touch with the Montpellier team, after having provided us with many casts of his private collection. We also thank Pr Paul Gigase for sending us casts of several specimens of Aumelas' Lophiotherium. We express our gratitude to the anonymous referees who reviewed the manuscript and thus allowed us to improve it. We dedicate this paper to our, recently passed away, dear colleague Dr Jens Lorenz Franzen.

\section{REFERENCES}

Badiola A., Pereda-Suberbiola X. \& Cuesta M. A. 2005. - Una nueva especie de Pachynolophus (Mammalia, Perissodactyla) de Zambrana (Álava, RegiónVasco-Cantábrica). Análisis filogenético de Pachynolophus y primera cita en el Eoceno superior de la Península Ibérica. Geobios 38: 1-16. https://doi.org/10.1016/j. geobios.2003.07.005

BioCHROM'97 (collectif) 1997. - Synthèses et Tableaux de corrélations, in Aguilar J.-P., Legendre S. \& Michaux J. (eds), Actes du Congrès BiochroM'97. Mémoires et Travaux de l'EPHE, Institut de Montpellier: 769-805.

Brunet M. \& JeHENNE Y. 1989. — Révision des genres Plagiolophus Pomel, 1847 et Paloplotherium Owen, 1848, (Mammalia, Palaeotheriidae) du Paléogène d'Europe; intérêt biochronologique. Annales de Paléontologie (Vertébrés) 75 (1): 23-52.

CheCA-Soler L. 1994. - Los Perisodáctilos (Ungulata, Mammalia) del Eoceno Catalán. Tesis Doctoral, Facultad de Biologia, Universidad de Barcelona.

CHeCA-SOLER L. 1997. — Los perisodàctilos (Mammalia, Ungulata) del eoceno catalàn. Paleontologia i Evolucio 30-31: 149-234.

Comte B., Sabatier M., Marandat B. \& Vianey-Liaud M. 2012. - Les Rongeurs de Chéry-Chartreuve et Rocourt-SaintMartin (Est du Bassin de Paris; Aisne, France). Leur place parmi les faunes de l'Éocène supérieur d'Europe. Palaeovertebrata 37 (4-5): 167-271. https://doi.org/10.18563/pv.37.4-5.167-271

CROCHET J.-Y. 1979. - Diversité systématique des Didelphidés (Marsupiala) européens tertiaires. Geobios 11 (3): 365-378. https://doi.org/10.1016/S0016-6995(79)80117-5

Crochet J.-Y., Godinot M., Hartenberger J.-L., Remy J. A., Sigé B. \& Sudre J. 1988. — Découverte dans le bassin de StMartin-de-Londres (Hérault, Sud de la France) d'un gisement à vertébrés continentaux d'âge éocène moyen. Courier Forschungsinstitut Senckenberg 107: 419-434.

Danilo L., Remy J. A., Vianey-Liaud M., Marandat B., Sudre J. \& LIHOREAU F. 2013. - A new Eocene locality in southern France sheds light on the basal radiation of Palaeotheriidae (Mammalia, Perissodactyla, Equoidea). Journal of Vertebrate Paleontology 33 (1): 195-215. https://doi.org/10.1080/02724634.2012.711404

DEPÉRET C. 1917. - Monographie de la faune de mammiferes fossiles du Ludien inférieur d'Euzet-les-Bains (Gard). Annales de l'Université de Lyon, n. sér., I, Sciences, Médecine 40: 1-228, 25 pls.

ESCARGUEL G. 1999. — Les Rongeurs de l'Éocène inférieur et moyen d'Europe occidentale. Systématique, phylogénie, biochronologie et paléobiogéographie des niveaux-repères MP 7 à MP 14. Palaeovertebrata 28 (2-4): 89-351, 26 pls.

Escarguel G., Marandat B. \& Legendre S. 1997. - Sur l'âge numérique des faunes de mammifères du Paléogène d'Europe occidentale, en particulier celles de l'Éocène inférieur et moyen, in Aguilar J.-P., Legendre S. \& Michaux J. (eds), Actes du Congrès BiochroM'97. Mémoires et Travaux de l'EPHE, Institut de Montpellier, Montpellier: 443-460.

ForTELIUS M. 1985. - Ungulate cheek teeth: developmental, functional, and evolutionary interrelations. Acta Zoologica Fennica 180: 1-76. 
FranZEN J. L. 1988. — Skeletons of Aumelasia (Mammalia, Artiodactyla, Dichobunidae) from Messel (M. Eocene, W. Germany). Courier Forschungsinstitut Senckenberg 107: 309-321.

FrANZEN J. L. 1999. - Lophiotherium sondaari n. sp. (Mammalia, Perissodactyla, Equidae) aus der oberen Unterkohle des Geiseltales bei Halle (Saale), in Reumer J. W. F. \& De Vos J. (eds), Elephants have a Snorkel! Papers in honour of Paul Y. Sondaar. Natural History Museum, Deinsea: 187-194.

FRANZEN J. L. 2005. - The implications of the numerical dating of the Messel fossil deposit (Eocene, Germany) for mammalian biochronology. Annales de Paléontologie 91: 329-335. https:// doi.org/10.1016/j.annpal.2005.04.002

FRANZEN J. L. 2006. - Eurohippus n. g., a new genus of horses from the Middle to Late Eocene of Europe. Senckenbergiana Lethaea 86 (1): 97-102. https://doi.org/10.1007/BF03043638

Franzen J. L. \& Haubold H. 1986a. - Revision der Equoidea aus den eozänen Braunkohlen des Geiseltales bei Halle (DDR). Palaeovertebrata 16 (1): 1-34.

Franzen J. L. \& HaubOLD H. 1986b. - The Middle Eocene of European Mammalian Stratigraphy. Definition of the Geiseltalian. Modern Geology 10: 159-170.

Froehlich D. J. 1999. - Phylogenetic Systematics of Basal Perissodactyls. Journal of Vertebrate Paleontology 19 (1): 140-159. https://doi.org/10.1080/02724634.1999.10011129

FroeHlich D. J. 2002. - Quo vadis eohippus? The systematics and taxonomy of the early Eocene equids (Perissodactyla). Zoological Journal of the Linnean Society 134: 141-256. https://doi. org/10.1046/j.1096-3642.2002.00005.x

Ginsburg L., Arques J., Broin F. De, Le Calvez Y., Mouton J., Obert D., Privé-Gill C. \& RoucAn J.-P. 1977. - Découverte d'une faune de mammifères dans le Lutétien supérieur de la Défense, à Puteaux, près Paris (Hauts-de-Seine). Comptes-rendus sommaires de la Société géologique de France 1977 (6): 311-313.

Godinot M., CROChet J.-Y., HARTENBERGER J.-L., LANGE-BADRÉ B., Russell D. E. \& Sigé B. 1987. — Nouvelles données sur les mammiferes de Palette (Éocène inférieur, Provence). Münchner geowissenschaftliche Abhandlungen A (10): 273-288.

Godinot M. 1988. - Les Primates adapidés de Bouxwiller (Eocène Moyen, Alsace) et leur apport à la compréhension de la faune de Messel et à l'évolution des Anchomomyini. Courier Forschungsinstitut Senckenberg 107: 383-407.

Godinot M., Labarrère H.-P., ERFurT J., Franzen J. L., LANGeBadré B., de Lapparent de Broin F. \& Vidalenc D. 2018. Un nouveau gisement à vertébrés éocènes, Rouzilhac (MP 10-11), dans la série molassique d'Issel (Aude, France). Revue de Paléobiologie 37 (1): 141-333.

Gradstein F. M., OgG J. G. \& Hilgen F. J. 2012. - On The Geologic Time Scale. Newsletters on Stratigraphy 45 (2): 171-188. https://doi.org/10.1127/0078-0421/2012/0020

HARTENBERGER J.-L. 1963. - Un gisement de la zone de mammiferes d'Issel (Éocène moyen) dans les calcaires lacustres d'Aumelas (Hérault). Comptes-rendus sommaires de la Société géologique de France 1963 (9): 321-322.

HARTENBERGER J.-L. 1973. - Étude systématique des Theridomorphidea (Rodentia) de l'Éocène supérieur. Mémoires de la Société géologique de France, nelle sér., 52 (Mém. 117): 1-76.

Hartenberger J.-L., Sigé B. \& Sudre J. 1969. — Les gisements de vertébrés de la région montpelliéraine. 1. Gisements éocènes. Bulletin du Bureau de Recherches géologiques et minières, 2e sér., section 1:7-18.

Hellmund M. 2000. - Erstnachweis von Plagiolophus cartieri Stehlin (Palaeotheriidae, Perissodactyla) in der unteren Mittelkohle (uMK, MP 12) des Geiseltales bei Halle (Sachsen-Anhalt, Deutschland). Neues Jahrbuch für Mineralogie Geologie Paläontologie: 205-216.

HoOKER J. J. 1986. - Mammals from the Bartonian (middle/late Eocene) of the Hampshire Basin, southern England. Bulletin of the British Museum (Natural History) (Geology) 39 (4): 191-478. http://www.biodiversitylibrary.org/page/36531704
HoOKer J. J. 1994. - The beginning of the equoid radiation. Zoological Journal of the Linnean Society 112: 29-63. https://doi. org/10.1111/j.1096-3642.1994.tb00311.x

HoOKer J. J. \& WeIDMANN M. 2000. - The Eocene mammal faunas of Mormont, Switzerland. Systematic revision and resolution of dating problems. Schweizerische Paläontologische Abhandlungen 120: 1-143.

Janis C. M. 1988. - 29. An Estimation of Tooth Volume and Hypsodonty Indices in Ungulate Mammals, and the Correlation of these Factors with Dietary Preference, in Russell D. E., SANTORO J.-P. \& SigOGNEAU-RUSSELl D. (eds), Teeth Revisited: Proceedings of the VIIth International Symposium on Dental Morphology. Muséum national d'Histoire naturelle, Paris: 367-387 (Mémoires du Muséum national d'Histoire naturelle, sér. C - Sciences de la Terre; 53).

JANIS C. M. 1990. - Correlation of cranial and dental variables with body size in ungulates and macropodoids, in DAMUTH J. \& MACFADDEN B.J. (eds), Body size in mammalian paleobiology: Estimation and biological implications. Cambridge University Press, Cambridge, New York: 255-299 + appendices 16-8 to 16-10. https://doi.org/10.1007/BF02192193

Maitre E. 2014. - Western European middle Eocene to early Oligocene Chiroptera: systematics, phylogeny and palaeoecology based on new material from the Quercy (France). Swiss Journal of Palaeontology 133: 141-242. https://doi.org/10.1007/s13358014-0069-3

Maitre E., Escarguel G. \& Sigé B. 2008. - Amphilemuridae éocènes d'Europe occidentale - Nouvelles données, formes affines, systématique et phylogénie. Palaeontographica Abteilung $A$ Band 283 (1-3): 35-82.

MARTIN J. E. 2016. - New material of the ziphodont mesoeucrocodylian Iberosuchus from the Eocene of Languedoc, Southern France. Annales de Paléontologie 102 (2): 135-144. https://doi. org/10.1016/j.annpal.2016.05.002

Osborn H. F. 1918. - Equidae of the Oligocene, Miocene and Pliocene of North-America. Iconographic Type revision. Memoirs of the American Museum of Natural History, n. ser., 2 (1): 1-217, 54 pls.

PFretzSCHNER H. U. 1994. - Biomechanik der Schmelzmikrostruktur in den Backenzähnen von Grossäugern. Palaeontographica A 234: $1-88+15$ pls.

Remy J. A. 1972. - Étude du crâne de Pachynolophus lavocati n. sp. (Perissodactyla, Palaeotheriidae) des Phosphorites du Quercy. Palaeovertebrata 5 (2): 45-78. https://doi.org/10.18563/pv.5.2.45-78

REMY J. A. 1976. - Étude comparative des structures dentaires chez les Palaeotheriidae et divers autres Périssodactyles fossiles. Thèse de 3 ème cycle, Université Strasbourg I, non publiée.

ReMY J. A. 1988. — Le gisement du Bretou (Phosphorites du Quercy, Tarn-et-Garonne, France) et sa faune de Vertébrés de l'Éocène supérieur. VIII. Périssodactyles. Palaeontographica A 205: 155-172.

REMY J. A. 1992. - Observations sur l'anatomie crânienne du genre Palaeotherium (Perissodactyla, Mammalia); mise en évidence d'un nouveau sous-genre, Franzenitherium. Palaeovertebrata 21 (3-4): 103-224.

RemY J. A. 1998. - Le genre Leptolophus (Perissodactyla, Mammalia) : morphologie et histologie dentaires, anatomie crânienne, implications fonctionnelles. Palaeovertebrata 27 (1-2): 45-108.

Remy J. A. 2004. - Le genre Plagiolophus (Palaeotheriidae, Perissodactyla, Mammalia) : Révision systématique, morphologie et histologie dentaires, anatomie crânienne, essai d'interprétation fonctionnelle. Palaeovertebrata 33 (1-4): 17-281. https://doi. org/10.18563/pv.37.1-3.1-165

Remy J. A. 2012. - Révision systématique des Anchilophini (Palaeotheriidae, Perissodactyla, Mammalia). Palaeovertebrata 37 (1-3) 1-165. https://doi.org/10.18563/pv.37.1-3.1-165

Remy J. A. 2015. - Les Périssodactyles (Mammalia) du gisement Bartonien supérieur de Robiac (Éocène moyen du Gard, Sud de la France). Palaeovertebrata 39 (1): 1-98. https://doi. org/10.18563/pv.39.1.e3 
RemY J. A. 2017. - Critical comments on the genus Propachynolophus Lemoine, 1891 (Mammalia, Perissodactyla, Equoidea). Palaeovertebrata 41 (1)-e3: 1-18. https://doi.org/10.18563/pv.41.1.e3 Remy J. A., Krasovec G. \& Marandat B. 2016. - A new species of Propalaeotherium (Palaeotheriidae, Perissodactyla, Mammalia) from the Middle Eocene locality of Aumelas (Hérault, France). Palaeovertebrata 40 (2): 1-8, supp. data 1-6. https://doi. org/10.18563/pv.40.2.e1

Savage D. E., Russell D. E. \& Louis P. 1965. - European Eocene Equidae (Perissodactyla). University of California Publications in Geological Sciences, vol. 56, 94 p.

SCHMiDT-KitTLER N. 1987. - European Reference Levels and Correlation Tables. International Symposium on Mammalian Biostratigraphy and Paleoecology of the European Paleogene, Mainz. Münchner Geowissenschaftliche Abhandlungen: 13-31.

Simpson G. G. 1952. — Notes on British hyracotheres. Zoological Journal of the Linnean Society 42: 195-206.

STEHLIN H. G. 1904. — Die Säugetiere des schweizerischen Eocaens. Critisher Catalog der Materialen. 2er Teil. Abhandlungen der schweizerischen paläontologischen Gesellschaft 31: 154-445.

STEHLIN H. G. 1905. — Die Säugetiere des schweizerischen Eocaens.
Critisher Catalog der Materialen. 3er Teil. Abhandlungen der schweizerischen paläontologischen Gesellschaft 32: 447-595.

SUDRE J. 1978. - Les Artiodactyles de l'Éocène moyen et supérieur d'Europe occidentale (Systématique et évolution). Mémoires et Travaux de l'E.P.H.E., Institut de Montpellier, vol. 7: 1-229.

SUDRE J. 1980. - Aumelasia gabineaudi n.g. n.sp. nouveau Dichobunidae (Artiodactyla, Mammalia) du gisement d'Aumelas (Hérault) d'âge Lutétien terminal. Palaeovertebrata, Mémoire Jubilaire $R$. Lavocat: 197-211.

SUDRE J. 1988. - Apport à la connaissance du Dichobune robertiana Gervais, 1848-1852 (Mammalia, Artiodactyla) du Lutétien: considération sur l'évolution des Dichobunidés. Courier Forschungsinstitut Senckenberg 107: 409-418.

Turnbull W. D. 1970. - Mammalian Masticatory Apparatus. Fieldiana, Geology 18 (2): 149-356. https://doi.org/10.5962/ bhl.title. 5442

Wade B. S., Pearson P. N., Berggren W. A. \& Pälike H. 2011. Review and revision of Cenozoic tropical planktonic foraminiferal biostratigraphy and calibration to the Geomagnetic Polarity and Astronomical Time Scale. Earth-Science Reviews 104 (1-3): 111142. https://doi.org/10.1016/j.earscirev.2010.09.003

Submitted on 29 July 2018 accepted on 27 February 2019; published on 11 July 2019. 


\section{APPENDICES}

APPENDIX 1. - Description of characters used in the cladistic analysis. All characters are treated as unweighted.

1 Nasal notch: mesially to the canine (0); above the DPC, close to the canine (1); above the DPC, close to the premolars (2); distally to the first premolar (3). (Character 1 in Danilo et al. [2013]).

2 Bones surrounding the nasal notch: premaxilla enlarged upward and nasal (0); premaxilla reduced upward and nasal (1); premaxilla, maxilla, and nasal (2). (Character 2 in Danilo et al. [2013]).

3 Lacrimal tubercle: present (0); missing (1). (Character 3 in Danilo et al. [2013]).

4 Orbital border: reaches $\mathrm{Ml} /(0)$; reaches the limit between $\mathrm{Ml}$ / and M2/ (1); reaches M2/ (2); reaches the limit between M2/ and M3/ (3). (Character 4 in Danilo et al. [2013]).

5 Position of basicranial foramina: foramen ovale and middle lacerate foramen distant (0); separated only by a narrow bridge of bone (1); confluent (2). (Character 5 in Danilo et al. [2013]).

6 Braincase index (measure from the mesial side of P2/ to the orbital border/measure from the orbital border to the midway of the distal line of the occipital): from 0.25 to 0.30 (0); from 0.35 to 0.40 (1); more than 0.45 (2). (Character 6 in Danilo et al. [2013]).

7 Postcanine diastem length (C-P2 at the bone level): short (less than 25\% of the P2-M3 length) (0); 25-45\% (1); longer than $45 \%(2)$. (Modified from character 7 in Danilo et al. [2013]).

8 Degree of lophodonty: dentition very bunodont (0); buno-lophodont (1); lophodont (2).

9 P1: present (0); missing (1). (Character 8 in Danilo et al. [2013]).

10 P1 elongation: shorter than P2 (0); as long as or longer than P2 (1). (Character 9 in Danilo et al. [2013]).

11 Post-P1 diastema: constant (0); occasional (1); missing (2). (Modified from character 10 in Danilo et al. [2013]).

12 P2/ occlusal outline: triangular, tapering forward (0); wider but mesial side slanted (1); almost rectangular (2). (Character 11 in Danilo et al. [2013]).

13 P2/ labial cusps: one cusp (0); two cusps (1). (Character 12 in Danilo et al. [2013]).

14 P2/ molarization: missing (0); incomplete (1); complete (2). (Character 13 in Danilo et al. [2013]).

$15 \mathrm{P} 3 /$ postprotocrista morphology: missing $(0)$; incomplete (1); complete (2). (Modified from characters 14-15 in Danilo et al. [2013]).

$16 \mathrm{P} 3 /$ paraconule: indistinct (0); conspicuous, well defined (1). (Character 16 in Danilo et al. [2013]).

$17 \mathrm{P} 3 /$ metaconule: indistinct (0); conspicuous more or less separated from the protocone (1); lophodont (2). (Character 17 in Danilo et al. [2013]).

18 P3/-P4/ molarization: hypocone missing (0); present (1). (Character 18 in Danilo et al. [2013]).
$19 \mathrm{P} 3 /-\mathrm{P} 4 /$ accessory crest from the protocone (additionally of the postprotocrista): missing (0); present (1); present and joining the cingulum (2). (Character 19 in Danilo et al. [2013]).

20 P4/ occlusal outline: triangular (0); subquadrangular (1); square or rectangular (2). (Character 20 in Danilo et al. [2013]).

21 P4/ mesostyle: never (0); occasionally or always (1).

22 P4/ lingual cingulum: strong and continuous (0); reduced on the protocone (1); missing (2). (Modified from character 21 in Danilo et al. [2013]).

$23 \mathrm{P} 4 /$ posterolingual cingulum: no thicker than the anterior cingulum (0); important distal expansion (1). (Character 22 in Danilo et al. [2013]).

24 P4/ postprotocrista: present (0); missing (1). (Character 23 in Danilo et al. [2013]).

25 P4/ postprotocrista morphology: lophoid, joining ectoloph (0); incomplete, not joining ectoloph (1). (Character 24 in Danilo et al. [2013]).

$26 \mathrm{P} 4 /$ protocone position: central (0); mesially shifted (1). (Character 25 in Danilo et al. [2013]).

27 P4/ paraconule: strong (0); average (1); weak (2). (Character 26 in Danilo et al. [2013]).

28 P4/ metaconule: weak (0); average (1); strong (2). (Character 27 in Danilo et al. [2013]).

$29 \mathrm{P}$ // metaconule position: fused with the postprotocrista (0); distal to the postprotocrista.

30 Upper molar hypsodonty $(\mathrm{IH}=\mathrm{H} / \mathrm{W})$ : IH mostly $<0.50$ (0); mostly $>0.50$ up to 0.70 (1); mostly $>0.70$ (2). (Modified from character 28 in Danilo et al. [2013]).

31 Upper molar protoloph grooves size: strong (0); average (1); weak (2); missing (3). (Modified from characters 29-30 in Danilo et al. [2013]).

32 Upper molar metaloph grooves size: strong (0); average (1); weak (2); missing (3). (Modified from characters 31-32 in Danilo et al. [2013]).

33 Upper molar ectoloph centrocrista: deeply notched (0); moderately (1); shallow (2). (Character 52 in Froehlich [2002]).

34 Upper molar protoloph-ectoloph junction: unnotched (0); notched (1). (Character 36 in Danilo et al. [2013]).

35 Direction of the upper molar preparaconule cristaectoloph junction: directed towards the preparacrista (0); towards the parastyle (1). (Character 37 in Danilo et al. [2013]).

36 Upper molar metaloph-ectoloph junction: towards the metacone or interrupted (0); towards the centrocrista (1). (Character 38 in Danilo et al. [2013]).

37 Upper molar paracone labial ripple on the ectoloph: strong (0); weak (1); missing (2). (Character 39 in Danilo et al. [2013]). 
38 Upper molar metacone labial ripple on the ectoloph: strong (0); weak (1); missing (2). (Modified from character 40 in Danilo et al. [2013]).

39 Upper molar parastyle: low (0); small but high (1); large and protruding (2). (Modified from characters 41-42 in Danilo et al. [2013]).

40 Upper molar mesostyle: missing (0); occasional (1); constant (2). (Modified from character 43 in Danilo et al. [2013]).

41 Upper molar mesostyle morphology: strong rib up to the occlusal level, bulging with ectocingulum (0); strong but separated from ectocingulum (1); thin and not bulging at the collar (2); pseudomesostyle, i.e., occasional thin rib on the superior edge of the labial side (3). (Modified from character 44 in Danilo et al. [2013]).

42 Upper molar ectocingulum: continuous (0); usually interrupted on the paracone (1); almost missing (2). (Character 45 in Danilo et al. [2013]).

43 Upper molar ectocingulum thickness: strong (0); medium to weak (1).

44 Upper molar lingual cingulum morphology: continuous (0); interrupted (1); missing (2). (Modified from characters 46-47 in Danilo et al. [2013]).

45 Upper molar lingual cingulum thickness: strong (0); medium to weak (1); restricted to the medivallum (2). (Character 48 in Danilo et al. [2013]).

46 Localisation of the distal cingulum expansion: only on M3/ (0); on all upper molars (1); missing (2). (Modified from characters 49-50 in Danilo et al. [2013]).

47 Average height of (upper or lower) molar cingula $(\mathrm{CH}=$ Hcingulum/Hcrown): high, >45 (0); moderate, 30-45 (1); low <30 (2). (Modified from character 61 in Danilo et al., 2013).

48 Upper molar lingual cusps position: hypocone and protocone at the same level (0); hypocone more labial (1). (Character 51 in Danilo et al. [2013]).

49 Upper molar lingual cusps size: protocone and hypocone similar in size (0); protocone larger than the hypocone (1). (Character 52 in Danilo et al. [2013]).

$50 \mathrm{Ml}-2 /$ metastyle orientation: in line with the ectoloph (in the alignment of the paracone and metacone) (0); oblique (towards labial side) (1). (Character 53 in Danilo et al. [2013]).
51 M3/ distal outline: convex (0); straight (1); concave (2). (Character 55 in Danilo et al. [2013]).

$52 \mathrm{M} 3 /$ relative distances between paracone-metacone and protocone-hypocone: subequal to equal (0); larger between protocone and hypocone (1). (Character 56 in Danilo et al. [2013]).

53 Relative surface of the premolar series (following SP/ SM index): low (<41) (0); intermediate (41-55) (1); high $(>55)(2)$.

54 Relative surface of M3/ on M2/ (following SM3/SM2 index): M3/ smaller than M2/ $(<0.95)(0)$; weak difference $(>0.95$ and $<1.05)$ (1); M3/ larger than M2/ (>1.05) (2). (Character 54 in Danilo et al. [2013]).

55 Relative surface of P4/ (following SP4/SM index): low $(<20)$ (0); intermediate (20-25) (1); high (>25) (2).

56 P/4 entoconid: missing (0); incipient and low (1); fully developed (2). (Modified from character 58 in Danilo et al. [2013]).

57 Lower molar relative width: narrow (L/W [M/1-2] $>1.45$ and $\mathrm{L} / \mathrm{W}[\mathrm{M} / 3]>2$ ) (0); wide (1). (Character 59 in Danilo et al. [2013]).

58 Lower molar ectocingulum: always thick and continuous (0); generally narrow and more or less interrupted (1); almost missing or limited to the medivallum (2). (Modified from character 60 in Danilo et al. [2013]).

59 Lower molar orientation of the protolophid and hypolophid: transversal (0); slightly inclined (1). (Character 62 in Danilo et al. [2013]).

60 Lower molar protolophid morphology: deeply notched (0); slightly notched (1); almost lophodont (2). (Modified from character 89 in Froehlich [2002]).

61 Lower molar twinned metaconid: missing (0); present (1). (Character 64 in Danilo et al. [2013]).

62 M/1-M/2 hypoconulid: developed (0); weak (1); missing (2). (Character 66 in Danilo et al. [2013]).

$63 \mathrm{M} / 3$ hypoconulid basin: large (0); reduced (1). (Character 67 in Danilo et al. [2013]).

$64 \mathrm{M} / 3$ prehypocristulid orientation: towards the hypoconid (0); towards the midpoint of the hypolophid (1); towards the entoconid (2). Character 70 in Danilo et al. [2013]).

$65 \mathrm{M} / 3$ accessory crest: missing (0); present (1). (Character 71 in Danilo et al. [2013]).

$66 \mathrm{M} / 3$ hypoconulid position: labial (0); medial (1); lingual (2). (Character 72 in Danilo et al. [2013]). 
APPENDIX 2. - Matrix drawn up for the cladistic analysis.

12234455667889101112131415161718192021222324252627282930313233

Cardiolophus radinskyi

Hallensia matthesi

Pliolophus vulpiceps

Hyracotherium leporinum

Propalaeotherium gaudryi

Orolophus maldani

'Hyracotherium' levei

'Hyracotherium' remyi

Pachynolophus duvali

Pachynolophus cesserasicus

Pachynolophus eulaliensis

Pachynolophus livinierensis

Eurohippus parvulus

Propalaeotherium hassiacum

Propalaeotherium isselanum

Propalaeotherium sudrei

Lophiotherium pygmaeum

Lophiotherium cervulum

Palaeotherium magnum

Plagiolophus minor

Leptolophus nouleti

Pachynolophus ruscassierensis $\mathrm{n} . \mathrm{sp}$.

Pachynolophus sp. AUM

Propalaeotherium cf. gaudryi AUM

Lophiotherium sp. AUM

$0 \begin{array}{llllllllllllllllllllllllllllllll}0 & 0 & ? & 0 & 0 & 0 & 1 & 0 & 0 & 0 & 0 & 0 & 0 & 2 & 1 & 0 & 0 & 0 & 1 & 0 & 0 & 1 & 0 & 0 & 0 & 1 & 1 & 0 & 0 & 0 & 3 & 0\end{array}$ $\begin{array}{lllllllllllllllllllllllllllllllll}0 & 0 & 0 & 2 & ? & 2 & 0 & 0 & 0 & 0 & 0 & 0 & 0 & 0 & 1 & 1 & 1 & 0 & 0 & 1 & 0 & 1 & 0 & 0 & 1 & 1 & 0 & 2 & 0 & 0 & 0 & 0 & 0\end{array}$ $\begin{array}{lllllllllllllllllllllllllllllllll}2 & 0 & 1 & 2 & ? & 1 & 1 & 0 & 0 & 0 & 0 & 0 & 1 & 0 & 1 & 1 & 0 & 0 & 0 & 0 & 0 & 1 & 0 & 0 & 0 & 0 & 0 & 2 & 0 & 0 & 0 & 1 & 0\end{array}$

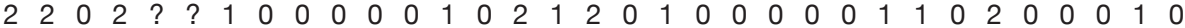
? ? ? ? ? ? ? ? ? ? ? 1 ? ? ? ? 1 ? ? ? ? ? 11 1 $00 \begin{array}{lllllllllllllll} & 0 & 0 & 1 & 1 & 0 & 1 & 1 & 0 & 1 & 0 & 0 & 1 & 2 & 0\end{array}$ ? ? ? ? ? ? ? 00 ? ? ? ? ? ? ? ? $00 \begin{array}{cccccccccccccccccc} & 0 & 0 & 0 & 0 & 0 & 0 & 0 & 0 & 1 & 0 & 0 & 1 & 0 & 0 & 1 & 2 & 0\end{array}$ ? ? ? ? ? ? ? 0 ? ? ? ? ? ? ? ? ? ? ? ? $00 \begin{array}{lllllllllllllll}0 & 0 & 0 & 1 & 1 & - & 0 & 0 & \text { ? } & - & 0 & 1 & 2 & 0\end{array}$ ? ? ? ? ? ? ? $\begin{array}{lllllllllllllllllllllllllllllllll}1 & 2 & 0 & 1 & ? & 0 & 2 & 0 & 0 & 0 & 1 & 0 & 1 & 0 & 0 & 1 & 0 & 0 & 0 & 0 & 0 & 0 & 0 & 0 & 0 & 0 & 1 & 1 & 0 & 0 & 1 & 3 & 0\end{array}$ $\begin{array}{lllllllllllllllllllllllllllllllll}1 & 1 & 0 & 2 & 2 & 0 & 1 & 1 & 0 & 0 & 1 & 0 & 1 & 0 & 1 & 1 & 0 & 0 & 0 & 0 & 0 & 1 & 0 & 0 & 0 / 1 & 1 & 1 & 1 & 1 & 0 & 1 & 3 & 0\end{array}$ ? $\quad$ ? $\quad 0 \begin{array}{llllllllllllllllllllllllllllllll} & 0 & 2 & 1 & 2 & 1 & 0 / 1 & 0 & 2 & 0 & 1 & 0 & 1 & 1 & 0 & 0 & 0 & 0 & 0 & 1 & 0 & 0 & 1 & 0 & 1 & 0 & 0 & 0 & 1 & 3 & 0\end{array}$

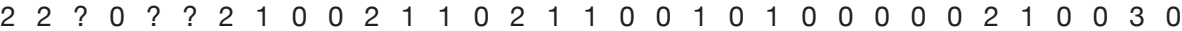
$\begin{array}{llllllllllllllllllllllllllllllllll}1 & 2 & ? & 2 & ? & ? & 0 / 1 & 0 & 0 & 0 & 1 & 0 / 1 & 0 & 0 & 2 & 1 & 0 & 0 & 0 & 1 & 0 & 1 & 0 & 0 & 0 & 0 & 0 & 2 & 0 & 0 & 0 & 3 & 0\end{array}$ $\begin{array}{lllllllllllllllllllllllllllllllll}2 & ? & 1 & 2 & 2 & 2 & 1 & 1 & 0 & 0 & 2 & 2 & 1 & 1 & 2 & 1 & 1 & 0 & 1 & 1 & 0 & 0 & 0 & 0 & 0 & 0 & 0 & 2 & 1 & 1 & 0 & 3 & 1\end{array}$ 22 ? 2 2 ?

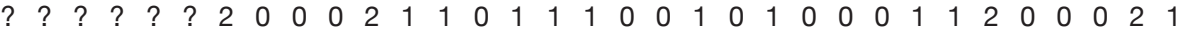
22 ? $20 \begin{array}{llllllllllllllllllllllllllll} & 2 & 2 & 0 & 0 & 0 & 2 & 2 & 1 & 1 & - & 1 & 1 & 1 & - & 2 & 1 & 1 & - & - & - & 0 & 2 & - & 0 & 0 & 0 & 1\end{array}$ $\begin{array}{llllllllllllllllllllllllllllllll}3 & 2 & 0 & 2 & 2 & 2 & 0 & 2 & 0 & 0 & 2 & 2 & 1 & 2 & - & 1 & 1 & 1 & - & 2 & 1 & 0 & - & - & - & 2 & 0 & -2 & 1 & 2 & 2\end{array}$

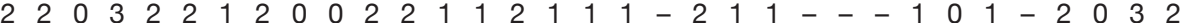

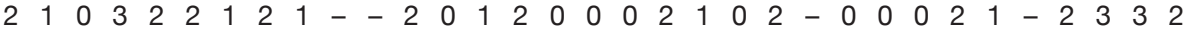
1 ? ? ? ? ? ? ? 22 1 ? ? ? ? ? ? ? ? $2 \begin{array}{lllllllllllllllllll} & 1 & 1 & 0 & 0 & 1 & 0 & 0 & 0 / 1 & 0 & 0 & 1 & 1 & 1 & 0 & 0 & 1 & 2 & \text { ? }\end{array}$ ? ? ? ? ? ? $\quad$ ? ? ? ? ? ? ? ? 0 ? ? ? ? ? ? ? ? ? ? ? ? ? ? ? ? ? ? ? ? ? 0 c 010

343536373839404142434445464748495051525354555657585960616263646566

Cardiolophus radinskyi

Hallensia matthesi

Pliolophus vulpiceps

Hyracotherium leporinum

Propalaeotherium gaudryi

Orolophus maldani

'Hyracotherium' levei

'Hyracotherium' remyi

Pachynolophus duvali

Pachynolophus cesserasicus

Pachynolophus eulaliensis

Pachynolophus livinierensis

Eurohippus parvulus

Propalaeotherium hassiacum

Propalaeotherium isselanum

Propalaeotherium sudrei

Lophiotherium pygmaeum

Lophiotherium cervulum

Palaeotherium magnum

Plagiolophus minor

Leptolophus nouleti

Pachynolophus ruscassierensis n. sp.

Pachynolophus sp. AUM

Propalaeotherium cf. gaudryi AUM

Lophiotherium sp. AUM $\begin{array}{lllllllllllllllllllllllllllllllll}0 & 0 & 0 & 0 & 0 & 2 & 1 & 0 & 0 & 0 & 0 & 1 & 2 & 1 & 0 & 0 & 0 & 0 & 0 & 1 & 0 & 0 & 0 & 1 & 0 & 0 & 1 & 0 & 0 & 1 & 0 & 0 & 0\end{array}$

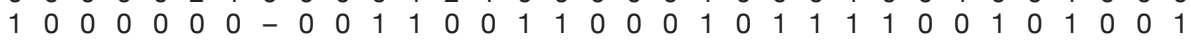
$\begin{array}{lllllllllllllllllllllllllllllllll}0 & 0 & 0 & 0 & 0 & 0 & 0 & - & 0 & 0 & 0 & 0 & 2 & 0 & 0 & 0 & 0 & 1 & 0 & 1 & 0 & 1 & 1 & 1 & 0 & 0 & 0 & 1 & 0 & 1 & 0 & 1 & 0\end{array}$ $\begin{array}{lllllllllllllllllllllllllllllllll}1 & 1 & 0 & 0 & 0 & 2 & 0 & - & 0 & 0 & 0 & 0 & 2 & 0 & 0 & 0 & 1 & 1 & 0 & 1 & 0 & 2 & ? & 1 & 0 & 1 & 0 & 1 & 0 & 1 & 0 & 1 & 1\end{array}$ $\begin{array}{lllllllllllllllllllllllllllllllll}1 & 0 & 0 & 0 & 1 & 2 & 1 & 0 & 0 & 0 & 1 & 1 & 2 & 1 & 0 & 0 & 1 & 1 & 0 & 1 & 1 & 0 & 1 & 1 & 1 & 1 & 1 & 1 & 1 & 0 & 1 & 1 & 0\end{array}$ $\begin{array}{lllllllllllllllllllllllllllllllll}1 & 0 & 0 & 0 & 1 & 1 & 1 & 1 & 0 & 0 & 1 & 0 & 2 & 1 & 0 & 0 & 0 & 1 & 0 & ? & 1 & ? & 1 & 0 & 0 & 0 & 0 & 1 & 0 & 1 & 1 & 0 & 1\end{array}$

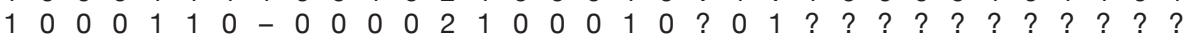
$\begin{array}{lllllllllllllllllllllllllllllllll}1 & 0 & 0 & 0 & 1 & 1 & 0 & - & 0 & 0 & 0 & 0 & 0 & 1 & 0 & 0 & 0 & 0 & 0 & ? & 1 & 0 & 0 & 1 & 1 & 1 & 0 & 1 & 0 & 1 & 1 & 1 & 1\end{array}$ $\begin{array}{lllllllllllllllllllllllllllllllll}0 & 0 & 0 & 0 & 1 & 1 & 0 & 3 & 1 & 1 & 1 & 2 & 0 & 1 & 0 & 0 & 1 & 0 & 0 & 1 & 1 & 1 & 1 & 0 & 1 & 1 & 1 & 1 & 0 & 1 & 1 & 1 & 1\end{array}$ $\begin{array}{llllllllllllllllllllllllllllll}0 & 1 & 0 & 0 & 1 & 1 & 0 & 3 & 0 & 1 & 1 & 0 & 0 & 1 & 0 & 0 & 1 & 1 & 0 & 0 & 2 & 0 & ? & ?\end{array} ?$ ? ? ? ? ? ? ? ? $\begin{array}{lllllllllllllllllllllllllllllllll}0 & 0 & 0 & 0 & 1 & 1 & 0 & 3 & 0 & 1 & 1 & 1 & 2 & 1 & 0 & 0 & 1 & 1 & 0 & 1 & 0 & 1 & 1 & 1 & 1 & 1 & 0 & 1 & 0 & 0 / 1 & 1 & 1 & 0\end{array}$ $\begin{array}{lllllllllllllllllllllllllllllllll}1 & 0 & 0 & 0 & 2 & 1 & 0 & ? & 1 & 1 & 1 & 2 & 0 & 1 & 0 & 0 & 1 & 2 & 0 & 1 & 2 & 0 & 1 & 1 & 1 & 1 & 1 & 1 & 0 & 0 & 1 & 1 & 1\end{array}$ $\begin{array}{lllllllllllllllllllllllllllllllll}1 & 1 & 1 & 0 & 1 & 2 & 2 & 0 & 1 & 1 & 1 & 1 & 2 & 1 & 0 & 0 & 1 & 1 & 0 & 1 & 1 & 1 & 1 & 0 & 1 & 1 & 0 & 1 & 1 & 0 & 1 & 0 & 1\end{array}$ $\begin{array}{lllllllllllllllllllllllllllllllll}1 & 1 & 1 & 0 & 1 & 2 & 2 & 0 & 0 & 0 & 0 & 1 & 2 & 1 & 1 & 1 & 1 & 1 & 0 & 1 & 1 & 0 & 1 & 1 & 1 & 0 & 1 & 1 & 1 & 1 & 1 & 1 & 1\end{array}$ $\begin{array}{lllllllllllllllllllllllllllllllll}1 & 0 & 1 & 1 & 1 & 1 & 2 & 1 & 0 & 0 & 1 & 1 & 2 & 1 & 1 & 0 & 1 & 1 & 0 & 1 & 1 & 1 & 0 & 1 & 0 & 1 & 1 & 1 & 1 & 1 & 2 & 0 & 0\end{array}$ $\begin{array}{lllllllllllllllllllllllllllllllll}1 & 0 & 1 & 0 & 1 & 2 & 2 & 1 & 0 & 0 & 1 & 1 & 2 & 1 & 0 & 0 & 1 & 1 & 0 & 1 & 1 & 0 & 1 & 1 & 1 & 0 & 1 & 1 & 1 & 0 & 1 & 1 & 0\end{array}$ $\begin{array}{lllllllllllllllllllllllllllllllll}1 & 1 & 0 & 0 & 1 & 1 & 1 & 1 & 1 & 1 & 1 & 1 & 2 & 1 & 0 & 0 & 1 & 0 & 0 & 1 & 1 & 1 & 1 & 1 & 1 & 0 & 0 & 1 & 1 & 0 & 1 & 1 & 0\end{array}$ $\begin{array}{lllllllllllllllllllllllllllllllll}1 & 1 & 0 & 0 & 0 & 1 & 2 & 0 & 1 & 1 & 1 & 2 & 1 & 1 & 0 & 0 & 1 & 0 & 0 & 2 & 1 & 2 & 2 & 1 & 1 & 0 & 0 & 1 & 1 & 0 & 1 & 1 & 0\end{array}$ $\begin{array}{lllllllllllllllllllllllllllllllll}0 & 1 & 0 & 1 & 2 & 1 & 2 & 0 & 0 & 1 & 1 & 1 & 1 & 2 & 0 & 1 & 1 & 1 & 0 & 2 & 2 & 2 & 2 & 0 & 0 & 1 & 2 & 0 & 2 & 1 & 2 & 1 & 0\end{array}$ $\begin{array}{lllllllllllllllllllllllllllllllll}0 & 1 & 1 & 1 & 1 & 1 & 2 & 0 & 1 & 1 & 1 & 1 & 0 & 2 & 0 & 0 & 1 & 0 & 0 & 0 & 2 & 0 & 1 & 0 & 2 & 1 & 2 & 1 & 0 & 1 & 2 & 1 & 1\end{array}$ $\begin{array}{lllllllllllllllllllllllllllllllll}0 & 0 & 1 & 1 & 1 & 1 & 2 & 2 & 2 & - & 2 & - & 0 & - & 0 & 0 & 0 & 0 & 0 & 0 & 1 & 0 & ? & 0 & 2 & 1 & 2 & ? & 2 & 1 & 2 & 1\end{array}$ ? $\begin{array}{lllllllllllllllllllllllllllllllll}0 & 0 & 0 & 0 & 1 & 1 & 0 & 3 & 0 & 1 & 1 & 1 & 2 & 1 & 0 & 0 & 1 & 1 & 0 & 1 & 1 & 1 & 1 & 0 & 1 & 1 & 1 & 1 & 0 & 0 & 1 & 1 & 1\end{array}$ $\begin{array}{lllllllllllllllllllllllllllllllll}0 & 0 & 0 & 0 & 1 & 1 & 0 & - & 1 & 1 & 1 & 1 & 2 & 1 & 0 & 0 & 1 & 0 & 0 & ? & 1 & 0 & ? & 1 & 1 & 1 & 1 & 1 & 0 & 0 & 1 & 1 & 1\end{array}$ $\begin{array}{lllllllllllllllllllllllllllllllll}1 & 0 & 0 & 0 & 1 & 2 & 1 & 0 & 0 & 0 & 1 & 1 & 2 & 1 & 0 & 0 & 1 & 1 & 0 & 1 & 1 & 1 & 1 & 1 & 1 & 1 & 1 & 1 & 1 & 0 & 1 & 1 & 0\end{array}$

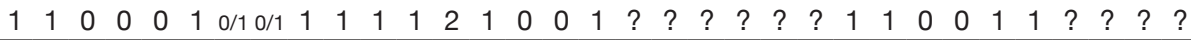


APPENDIX 3. - Measurements (in mm) of the cheek teeth specimens of Propalaeotherium sudrei Remy, Krasovec \& Marandat, 2016 from Aumelas. (See synthetic Table 1).

\section{Propalaeotherium sudrei}

\begin{tabular}{|c|c|c|c|c|c|c|c|c|c|c|c|c|c|c|c|c|c|c|}
\hline \multirow[b]{2}{*}{ specimens } & \multicolumn{2}{|c|}{ P2/ } & \multicolumn{2}{|c|}{ P3/ } & \multicolumn{3}{|c|}{ P4/ } & \multicolumn{4}{|c|}{ M1/ } & \multicolumn{4}{|c|}{ M2/ } & \multicolumn{3}{|c|}{ M3/ } \\
\hline & $\mathbf{L}$ & $\mathbf{W}$ & $\mathbf{L}$ & $\mathbf{W}$ & $\mathbf{L}$ & $\mathbf{W}$ & $\mathbf{L}$ & $\mathbf{W}$ & D & d & $\mathbf{L}$ & $\mathbf{w}$ & D & d & $\mathbf{L}$ & W & D & d \\
\hline AUM 181 & 7.1 & 5.9 & 8.0 & 8.3 & 8.5 & 10.1 & 10.3 & 12.2 & 12.7 & 13.3 & 11.5 & 14.0 & 14.0 & 14.8 & 11.9 & 13.7 & 15.4 & 14.0 \\
\hline AUM 173 & - & - & - & - & - & - & 10.8 & 12.9 & 13.7 & 13.0 & - & - & - & - & - & - & - & - \\
\hline AUM 174 & - & - & - & - & - & - & 9.4 & 11.1 & 11.6 & 11.1 & - & - & - & - & - & - & - & - \\
\hline AUM 175 & - & - & - & - & 8.4 & 11.2 & 9.5 & 12.0 & 13.0 & 12.4 & 11.1 & 13.7 & 14.2 & 13.1 & 11.5 & 13.7 & 14.0 & 13.6 \\
\hline AUM 201 & - & - & - & - & - & - & 11.5 & 12.5 & 14.3 & 12.5 & 12.9 & 14.6 & 15.7 & 13.7 & - & - & - & - \\
\hline AUM 202 & - & - & - & - & - & - & - & - & - & - & 11.9 & 13.8 & 15.8 & 14.1 & 12.5 & - & 15.5 & 14.4 \\
\hline AUM 207 & - & - & 8.1 & 9.7 & - & - & - & - & - & - & - & - & - & - & - & - & - & - \\
\hline AUM 221 & - & - & - & - & - & - & 11.0 & 12.8 & 14.2 & 12.2 & - & - & - & - & - & - & - & - \\
\hline AUM 1597 & - & - & - & - & 8.2 & 11.3 & - & - & - & - & - & - & - & - & - & - & - & - \\
\hline AUM 1598 & - & - & - & - & 9.4 & 11.4 & - & - & - & - & - & - & - & - & - & - & - & - \\
\hline AUM 1647 & - & - & - & - & 8.4 & 11.2 & - & - & - & - & - & - & - & - & - & - & - & - \\
\hline
\end{tabular}

\begin{tabular}{|c|c|c|c|c|c|c|c|c|c|}
\hline \multirow[b]{2}{*}{ specimen } & \multicolumn{4}{|c|}{ DP4/ } & \multirow{2}{*}{$\frac{\text { upper series }}{A U M 175}$} & \multirow{2}{*}{$\frac{L_{\text {P2-M3 }}}{-}$} & \multirow{2}{*}{$\frac{L_{P 2-P 4}}{-}$} & \multirow{2}{*}{$\begin{array}{l}\mathrm{L}_{\mathrm{M} 1-\mathrm{M} 3} \\
31.0\end{array}$} & \multirow{2}{*}{$\begin{array}{c}\text { PMI } \\
-\end{array}$} \\
\hline & $\mathbf{L}$ & $\mathbf{W}$ & D & d & & & & & \\
\hline AUM 223 & 9.5 & 10.3 & 11.7 & 10.1 & AUM 181 & 54.0 & 22.0 & 31.5 & 69.8 \\
\hline
\end{tabular}

\begin{tabular}{|c|c|c|c|c|c|c|c|c|c|c|c|c|c|c|c|c|c|c|c|}
\hline \multirow[b]{2}{*}{ specimens } & \multicolumn{3}{|c|}{$\mathrm{P} / 2$} & \multicolumn{3}{|c|}{$\mathrm{P} / 3$} & \multicolumn{3}{|c|}{$\mathrm{P} / 4$} & \multicolumn{3}{|c|}{$M / 1$} & \multicolumn{3}{|c|}{$M / 2$} & \multicolumn{4}{|c|}{$M / 3$} \\
\hline & $\mathbf{L}$ & W1 & W2 & $\mathbf{L}$ & W1 & W2 & $\mathbf{L}$ & W1 & W2 & $\mathbf{L}$ & W1 & W2 & $\mathbf{L}$ & W1 & W2 & $\mathbf{L}$ & W1 & W2 & W3 \\
\hline AUM 44 & - & - & - & - & - & - & - & - & - & - & - & - & 11.0 & 8.1 & 8.0 & - & - & - & - \\
\hline AUM 45 & - & - & - & - & - & - & - & - & - & 9.7 & 7.3 & 7.4 & - & - & - & - & - & - & - \\
\hline AUM 64 & - & - & - & - & - & - & - & - & - & - & - & - & - & - & - & - & 8.8 & 8.4 & - \\
\hline AUM 71 & 7.0 & 3.7 & 4.0 & 8.2 & 4.7 & 5.5 & - & - & - & - & - & - & - & - & - & - & - & - & - \\
\hline AUM 113 & - & - & - & - & - & - & - & - & - & - & - & - & - & - & - & 16.0 & 8.0 & 6.6 & 5.1 \\
\hline AUM 163 & - & - & - & - & - & - & - & - & - & - & - & - & 10.1 & 6.9 & 7.4 & 15.3 & 7.3 & 6.8 & 5.1 \\
\hline AUM 165 & - & - & - & - & - & - & - & - & - & - & - & - & 11.4 & 8.0 & 7.6 & - & 8.1 & 7.5 & - \\
\hline AUM 166 & - & - & - & 8.1 & 4.7 & 5.0 & 8.8 & 6.4 & 6.4 & 9.8 & 7.3 & 6.9 & - & - & - & - & - & - & - \\
\hline AUM 171 & - & 3.7 & 3.7 & 7.4 & 5.0 & 5.5 & 8.6 & 6.1 & 6.4 & - & - & - & - & - & - & - & - & - & - \\
\hline AUM 179 & - & - & - & - & - & - & 8.5 & 6.0 & 5.9 & 9.7 & 7.0 & 6.9 & 11.3 & 7.9 & 7.6 & 16.7 & 8.0 & 6.8 & 5.7 \\
\hline AUM 180 & - & - & - & - & - & - & - & - & - & - & - & - & - & - & - & - & - & 7.5 & 6.0 \\
\hline AUM 182* & - & - & - & - & - & - & - & - & - & 10.5 & 7.5 & 7.1 & - & - & - & - & - & - & - \\
\hline AUM 183 & - & - & - & - & - & - & - & - & - & - & - & - & 11.6 & 8.5 & 8.0 & 16.8 & 8.2 & 7.5 & 5.5 \\
\hline AUM 203 & - & - & - & - & - & - & - & - & - & - & - & - & - & - & - & 16.3 & - & - & - \\
\hline AUM 204 & - & - & - & - & - & - & - & - & - & - & - & - & - & - & - & - & 8.8 & 8.1 & - \\
\hline AUM 205 & - & - & - & - & - & - & - & - & - & - & - & - & - & - & - & 15.6 & 8.0 & 7.2 & 6.0 \\
\hline AUM 208 & - & - & - & - & - & - & 9.2 & 6.4 & 6.1 & 10.6 & 7.8 & 7.7 & 12.2 & 8.1 & 8.0 & 16.6 & 8.5 & 7.0 & 5.8 \\
\hline AUM 212 & - & - & - & - & - & - & - & - & - & - & - & - & - & - & - & 15.7 & 8.5 & 7.6 & 5.8 \\
\hline AUM 215 & - & - & - & - & - & - & - & - & - & - & - & - & - & - & - & 16.2 & 9.0 & 7.7 & 6.0 \\
\hline AUM 218 & - & - & - & - & - & - & - & - & - & - & - & - & - & - & - & 17.1 & 8.5 & 7.7 & 5.4 \\
\hline AUM 219 & - & - & - & - & - & - & - & - & - & - & - & - & 11.2 & 8.5 & 7.8 & - & - & - & - \\
\hline AUM 220 & - & - & - & - & - & - & - & - & - & - & - & - & 11.5 & 8.4 & 8.5 & - & - & - & - \\
\hline AUM 228 & - & - & - & - & - & - & - & - & - & - & - & - & - & - & - & 16.5 & 8.1 & 7.4 & 5.1 \\
\hline AUM 310 & - & - & - & - & - & - & 9.5 & 6.5 & 6.7 & - & - & - & 12.2 & 8.6 & 8.4 & - & 8.8 & - & - \\
\hline AUM 331 & 7.0 & 3.8 & 3.8 & 7.8 & 4.1 & 4.9 & 8.1 & 5.6 & 5.4 & 10.1 & 7.3 & 7.5 & - & - & - & - & - & - & - \\
\hline AUM 1572 & - & - & - & - & - & - & - & - & - & - & - & - & - & - & - & 13.9 & 7.0 & 6.3 & 5.4 \\
\hline AUM 1574 & - & - & - & - & - & - & 8.8 & 5.9 & 6.0 & - & - & - & - & - & - & - & - & - & - \\
\hline AUM 1609 & - & - & - & - & - & - & 9.7 & 6.0 & 6.3 & - & - & - & - & - & - & - & - & - & - \\
\hline AUM 1610 & - & - & - & - & - & - & 9.3 & 6.9 & 6.9 & - & - & - & - & - & - & - & - & - & - \\
\hline AUM 1611 & - & - & - & - & - & - & 9.1 & 5.7 & 6.5 & - & - & - & - & - & - & - & - & - & - \\
\hline AUM 1613 & - & - & - & - & - & - & - & - & - & - & - & - & - & - & - & 16.6 & 8.9 & 8.3 & 6.3 \\
\hline AUM 1614 & - & - & - & - & - & - & - & - & - & - & - & - & - & - & - & 17.7 & 8.5 & 7.2 & 5.4 \\
\hline AUM 1650 & - & - & - & - & - & - & - & - & - & - & - & - & 11.7 & 7.8 & 7.6 & - & - & - & - \\
\hline AUM 1651 & - & - & - & - & - & - & - & - & - & - & - & - & 11.9 & 8.3 & 7.9 & - & - & - & - \\
\hline AUM 1655 & - & - & - & - & - & - & - & - & - & - & - & - & - & - & - & 15.5 & 8.4 & 7.6 & 5.8 \\
\hline AUM 1656 & - & - & - & - & - & - & - & - & - & - & - & - & - & - & - & 14.7 & 7.8 & 7.2 & 5.3 \\
\hline
\end{tabular}

\begin{tabular}{lcccccccc}
\hline & \multicolumn{3}{c}{ DP/3 } & & \multicolumn{3}{c}{ DP/4 } \\
\cline { 2 - 4 } \cline { 6 - 8 } specimen & L & W1 & W2 & & L & W1 & W2 \\
\hline AUM 182* & - & - & 5.4 & 9.0 & 6.2 & 6.3 \\
\hline
\end{tabular}

\begin{tabular}{lcccc}
\hline lower series & $\mathbf{L}_{\mathbf{P 2}-\mathbf{M 3}}$ & $\mathbf{L}_{\mathbf{P 2}-\mathbf{P 4}}$ & $\mathbf{L}_{\mathbf{M 1} \text {-M3 }}$ & PMI \\
\hline AUM 179 & - & - & 38.7 & - \\
AUM 208 & - & - & 39.1 & -
\end{tabular}


APPENDIX 4. - Measurements (in $\mathrm{mm}$ ) of the cheek teeth specimens of Propalaeotherium cf. gaudryi from Aumelas. (See synthetic Table 2).

Propalaeotherium cf. gaudryi from Aumelas

\begin{tabular}{|c|c|c|c|c|c|c|c|c|c|c|c|c|c|c|c|c|c|c|}
\hline \multirow[b]{2}{*}{ specimens } & \multicolumn{2}{|c|}{ P2/ } & \multicolumn{2}{|c|}{ P3/ } & \multicolumn{2}{|c|}{ P4/ } & \multicolumn{4}{|c|}{ M1/ } & \multicolumn{4}{|c|}{ M2/ } & \multicolumn{4}{|c|}{ M3/ } \\
\hline & $\mathbf{L}$ & $\mathbf{W}$ & $\mathbf{L}$ & $\mathbf{W}$ & $\mathbf{L}$ & W & $\mathbf{L}$ & W & D & d & $\mathbf{L}$ & $\mathbf{W}$ & D & d & $\mathbf{L}$ & W & D & d \\
\hline AUM 47 & - & - & - & - & - & - & - & - & - & - & - & - & - & - & 13.8 & 15.2 & 17.6 & 13.7 \\
\hline AUM 164 & - & - & - & - & - & - & - & - & - & - & - & - & - & - & 13.2 & 15.4 & 16.1 & 15.0 \\
\hline AUM 168 & 8.0 & 6.7 & 8.7 & 10.3 & 9.1 & 11.7 & - & - & - & - & 13.1 & - & - & - & 13.5 & 14.6 & 15.5 & 14.2 \\
\hline AUM 192 & - & - & - & - & 8.9 & 13.2 & - & - & - & - & - & - & - & - & - & - & - & - \\
\hline AUM 209 & - & - & - & - & - & - & 11.7 & 14.3 & - & 14.3 & 14.7 & 17.0 & 18.3 & 16.2 & 14.7 & 16.8 & 17.8 & - \\
\hline AUM 1583 I & 7.0 & 7.7 & 8.0 & 10.9 & 8.4 & 12.2 & 11.4 & 14.1 & 15.1 & 13.5 & 12.6 & 15.3 & 16.4 & 14.9 & 12.8 & 16.1 & 16.2 & 14.9 \\
\hline AUM 1584 & 8.1 & 6.9 & 8.7 & 9.3 & 8.9 & 11.5 & 11.2 & 13.7 & 14.0 & 13.5 & 12.5 & 15.4 & 15.8 & 15.2 & 13.0 & 15.9 & 16.0 & 15.4 \\
\hline AUM 1585 & - & - & - & - & 8.7 & 12.9 & 11.5 & 13.8 & 14.8 & 13.4 & - & - & - & - & - & - & - & - \\
\hline AUM 1587 & - & - & - & - & - & - & - & - & - & - & 12.0 & 14.2 & 16.4 & 14.5 & 12.8 & 15.2 & 17.2 & 14.6 \\
\hline AUM 1590 & - & - & - & - & - & - & - & - & - & - & - & - & - & - & 15.4 & 17.9 & 19.4 & 16.2 \\
\hline AUM 1592 & - & - & - & - & - & - & - & - & - & - & 12.7 & 15.2 & 16.3 & 14.3 & - & - & - & - \\
\hline AUM 1593 & - & - & - & - & - & - & - & - & - & - & - & - & - & - & 13.5 & 14.3 & 17.3 & 13.9 \\
\hline AUM 1594 & - & - & - & - & 9.0 & 12.0 & - & - & - & - & - & - & - & - & - & - & - & - \\
\hline AUM 1595 & - & - & - & - & - & - & - & - & - & - & 13.0 & 15.6 & 17.4 & 15.1 & - & - & - & - \\
\hline AUM 1658 & - & - & - & - & - & - & - & - & - & - & - & - & - & - & 12.6 & 15.6 & 17.2 & 15.1 \\
\hline AUM 1659 & - & - & - & - & - & - & - & - & - & - & - & - & - & - & 12.6 & 15.0 & 16.3 & 14.2 \\
\hline
\end{tabular}

\begin{tabular}{lcccccc}
\hline upper series & $\mathbf{L}_{\text {DPC }}$ & $\mathbf{L}_{\mathbf{P 2}-\mathbf{M 3}}$ & \%DPC & $\mathbf{L}_{\mathbf{P 2}-\mathbf{P 4}}$ & $\mathbf{L}_{\mathbf{M} 1-\mathbf{M} 3}$ & PMI \\
\hline AUM 168 & 19.0 & 61.9 & 30.7 & 26.2 & 36.7 & 71.4 \\
AUM 209 & - & - & - & - & 37.6 & - \\
AUM 1583 & - & 60.2 & - & 24.2 & 35.7 & 67.8 \\
AUM 1584 & - & 60.1 & - & 25.5 & 36.1 & 70.6
\end{tabular}

\begin{tabular}{|c|c|c|c|c|c|c|c|c|c|c|c|c|c|c|c|c|c|c|c|}
\hline \multirow[b]{2}{*}{ specimens } & \multicolumn{3}{|c|}{$\mathrm{P} / 2$} & \multicolumn{3}{|c|}{$\mathrm{P} / 3$} & \multicolumn{3}{|c|}{$\mathrm{P} / 4$} & \multicolumn{3}{|c|}{ M/1 } & \multicolumn{3}{|c|}{$M / 2$} & \multicolumn{4}{|c|}{ M/3 } \\
\hline & $\mathbf{L}$ & W1 & W2 & $\mathbf{L}$ & W1 & W2 & $\mathbf{L}$ & W1 & W2 & $\mathbf{L}$ & W1 & W2 & $\mathbf{L}$ & W1 & W2 & $\mathbf{L}$ & W1 & W2 & W3 \\
\hline AUM 206 & - & - & - & 8.7 & 4.8 & 5.8 & 9.1 & 6.0 & 7.0 & 10.3 & 7.2 & 8.2 & 11.8 & 8.6 & 9.0 & 17.4 & 8.7 & 7.5 & 5.5 \\
\hline AUM 236 & - & - & - & 10.1 & 6.1 & 6.4 & - & - & - & - & - & - & - & - & - & - & - & - & - \\
\hline AUM 1560 & - & - & - & 9.1 & 5.6 & 6.7 & - & - & - & - & - & - & - & - & - & - & - & - & - \\
\hline AUM 1561 & 8.7 & 4.5 & 5.2 & - & - & - & - & - & - & - & - & - & - & - & - & - & - & - & - \\
\hline AUM 1601 & - & - & - & - & - & - & - & - & 7.1 & 10.3 & 7.7 & 7.6 & 12.3 & 9.0 & 8.5 & 17.1 & 8.8 & 7.7 & 5.8 \\
\hline AUM 1603 & - & - & - & - & - & 6.2 & 9.2 & 6.4 & 6.8 & 10.3 & 6.9 & 7.6 & 12.2 & 8.9 & 8.2 & 17.9 & 8.4 & 7.6 & 5.5 \\
\hline AUM 1604 & - & - & - & - & - & - & - & - & - & 11.3 & 7.0 & 7.1 & 12.7 & 7.9 & 7.7 & - & - & - & - \\
\hline AUM 1606 & - & - & - & - & - & - & 9.5 & 6.3 & 6.8 & 11.2 & 7.0 & 7.1 & 11.8 & 8.5 & 8.1 & 18.3 & 8.1 & 7.5 & 5.4 \\
\hline AUM 1607 & - & - & - & - & - & - & - & - & - & - & - & 7.7 & 12.1 & 9.2 & 8.1 & - & - & - & - \\
\hline AUM 1608 & - & - & - & - & - & - & - & - & - & - & - & - & 12.4 & 8.9 & 8.7 & - & - & - & - \\
\hline
\end{tabular}

\begin{tabular}{lcccc}
\hline lower series & $\mathbf{L}_{\mathbf{P 2}-\mathbf{M 3}}$ & $\mathbf{L}_{\mathbf{P 2}-\mathbf{P 4}}$ & $\mathbf{L}_{\mathbf{M 1} \text {-M3 }}$ & PMI \\
\hline AUM 206 & - & - & 40.0 & - \\
AUM 1601 & - & - & 40.8 & - \\
AUM 1603 & - & - & 40.9 & - \\
AUM 1606 & - & - & 41.6 & - \\
\hline
\end{tabular}


APPENDIX 5. - Measurements (in mm) of the cheek teeth specimens of Pachynolophus ruscassierensis n. sp. from Aumelas (see synthetic Table 3): 1, L $\mathrm{L}_{\mathrm{P} / \mathrm{P} / \mathrm{P} / \mathrm{f}}$

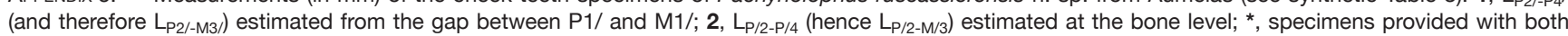
permanent and milk teeth.

Pachynolophus ruscassierensis n. sp.

\begin{tabular}{|c|c|c|c|c|c|c|c|c|c|c|c|c|c|c|c|c|c|c|}
\hline \multirow[b]{2}{*}{ specimens } & \multicolumn{2}{|c|}{ P2/ } & \multicolumn{2}{|c|}{ P3/ } & \multicolumn{2}{|c|}{ P4/ } & \multicolumn{4}{|c|}{ M1/ } & \multicolumn{4}{|c|}{ M2/ } & \multicolumn{4}{|c|}{ M3/ } \\
\hline & $\mathbf{L}$ & $\mathbf{W}$ & $\mathbf{L}$ & $\mathbf{W}$ & $\mathbf{L}$ & $\mathbf{W}$ & $\mathbf{L}$ & $\mathbf{W}$ & D & d & $\mathbf{L}$ & $\mathbf{W}$ & D & d & $\mathbf{L}$ & $\mathbf{W}$ & D & d \\
\hline AUM 48 & - & - & - & - & - & - & 10.0 & 11.9 & 12.4 & 11.9 & - & - & - & - & - & - & - & - \\
\hline AUM 70 & - & - & 8.3 & 9.2 & - & - & - & - & - & - & - & - & - & - & - & - & - & - \\
\hline AUM 138 & - & - & - & - & 8.4 & 10.0 & 9.8 & 12.1 & 12.6 & 12.1 & - & 13.9 & 14.9 & - & - & - & - & - \\
\hline AUM 176 & - & - & - & - & - & - & 9.3 & 11.2 & 11.9 & 11.2 & - & - & - & - & - & - & - & - \\
\hline AUM 187 & - & - & - & - & - & - & 9.3 & 11.3 & 12.3 & 10.6 & - & - & - & - & - & - & - & - \\
\hline AUM 189 & - & - & - & - & - & - & - & - & - & - & 12.2 & 14.2 & 15.2 & 13.3 & - & - & - & - \\
\hline AUM 191 & - & - & - & - & - & - & - & - & - & - & - & - & - & - & 10.5 & 12.3 & 12.8 & 11.4 \\
\hline AUM 194 & - & - & - & - & - & - & 10.1 & 12.1 & 12.2 & 12.0 & - & - & - & - & - & - & - & - \\
\hline AUM 197 & - & - & - & - & - & - & 9.6 & 10.9 & 12.1 & 10.6 & - & - & - & - & - & - & - & - \\
\hline AUM 210 & - & - & - & - & - & - & - & - & - & - & - & - & - & - & 11.0 & 13.0 & 13.6 & 12.7 \\
\hline AUM 211 & - & - & - & - & - & - & - & - & - & - & 11.6 & 13.9 & 14.7 & 13.4 & - & - & - & - \\
\hline AUM 216 & - & - & - & - & - & - & 9.0 & 11.8 & 12.2 & 10.3 & 10.1 & 13.0 & 13.7 & 11.7 & - & - & - & - \\
\hline AUM 224 & - & - & - & - & - & - & - & - & - & - & - & - & - & - & 12.0 & 14.3 & 15.1 & 13.6 \\
\hline AUM 231 & 6.5 & 5.8 & 7.9 & 9.4 & 8.1 & 10.4 & 10.0 & 11.8 & 12.7 & 11.9 & 11.1 & 13.3 & 14.0 & 13.2 & 12.0 & 13.5 & 14.3 & 13.4 \\
\hline AUM 235 & - & - & - & - & - & - & 10.7 & 12.6 & 13.6 & 12.3 & - & - & - & - & - & - & - & - \\
\hline AUM 304 & - & - & - & - & - & - & - & - & - & - & - & - & - & - & 12.1 & 14.0 & 15.4 & 13.9 \\
\hline AUM 321 & - & - & - & - & - & - & - & - & - & 10.5 & 10.6 & 11.1 & 12.7 & 10.2 & - & - & - & - \\
\hline AUM 324 & - & - & - & - & - & - & - & - & - & - & - & - & - & - & 10.3 & 12.4 & 12.6 & 11.5 \\
\hline AUM $1544 r$ & - & - & - & - & - & - & 10.0 & 12.0 & 12.6 & 11.9 & 11.3 & 13.4 & 14.0 & 13.4 & 11.0 & 13.2 & 14.6 & 13.3 \\
\hline AUM 1544 I & - & - & - & - & 7.3 & 9.5 & 10.0 & 11.8 & 12.6 & 12.0 & 11.5 & 13.0 & 14.0 & 13.3 & 11.1 & 12.9 & 14.3 & 13.1 \\
\hline AUM 1545 & - & - & - & - & - & - & 9.0 & 10.2 & 10.8 & 10.4 & 9.2 & 10.1 & 11.1 & 10.1 & - & - & - & - \\
\hline AUM 1546 & - & - & - & - & - & - & 9.0 & 11.1 & 10.8 & 10.9 & 9.4 & 10.6 & 11.4 & 10.9 & - & - & - & - \\
\hline AUM 1552 & 6.0 & 5.5 & 8.2 & 9.1 & 8.5 & 10.8 & 10.6 & 13.2 & 14.6 & 12.9 & 11.8 & 14.7 & 15.9 & 14.2 & - & - & - & - \\
\hline AUM 1553 & - & - & 7.1 & 9.6 & 9.0 & 11.5 & 10.5 & 13.0 & 13.8 & 12.6 & 11.7 & 13.5 & 14.6 & 13.5 & - & - & - & - \\
\hline AUM 1554 & - & - & - & - & 7.6 & 9.4 & 9.2 & 11.2 & 11.8 & 11.5 & 9.9 & 13.1 & 13.8 & 12.3 & - & - & - & - \\
\hline AUM 1555 & - & - & - & - & - & - & - & - & - & - & 11.5 & 13.6 & 14.5 & 13.9 & - & - & - & - \\
\hline AUM 1563 & - & - & - & - & - & - & - & - & - & - & 11.0 & 12.7 & 12.8 & 11.6 & 11.4 & 12.6 & 13.1 & 12.7 \\
\hline AUM 1564 & - & - & - & - & - & - & - & - & - & - & 9.5 & 10.9 & 11.3 & 10.5 & 10.9 & 12.2 & 12.9 & 11.8 \\
\hline AUM 1565 & - & - & - & - & - & - & - & - & - & - & 10.4 & 12.4 & 13.6 & 11.9 & - & - & - & - \\
\hline AUM 1566 & - & - & 7.3 & 9.4 & - & - & - & - & - & - & - & - & - & - & - & - & - & - \\
\hline AUM 1567 & - & - & - & - & 7.9 & 9.8 & - & - & - & - & - & - & - & - & - & - & - & - \\
\hline AUM 1619 & - & - & - & - & - & - & 10.0 & 12.1 & - & 12.8 & 11.5 & 13.8 & 14.8 & 14.0 & - & - & - & - \\
\hline AUM 1628 & - & - & 8.5 & 9.9 & 9.2 & 11.6 & 10.2 & 12.7 & 13.7 & 12.7 & 11.9 & 13.6 & - & 13.5 & - & - & - & - \\
\hline AUM 1632 & - & - & 7.4 & 9.4 & - & - & - & - & - & - & - & - & - & - & - & - & - & - \\
\hline AUM 1634 & - & - & - & - & - & - & - & - & - & - & - & - & - & - & 10.3 & 12.1 & 13.5 & 11.9 \\
\hline
\end{tabular}

\begin{tabular}{|c|c|c|c|c|c|c|c|c|c|c|c|c|}
\hline \multirow[b]{2}{*}{ specimens } & \multicolumn{4}{|c|}{ DP2/ } & \multicolumn{4}{|c|}{ DP3/ } & \multicolumn{4}{|c|}{ DP4/ } \\
\hline & $\mathbf{L}$ & $\mathbf{W}$ & D & d & $\mathbf{L}$ & $\mathbf{W}$ & D & d & $\mathbf{L}$ & $\mathbf{W}$ & D & d \\
\hline AUM 186 & - & - & - & - & 9.0 & 9.8 & 10.6 & 9.8 & - & - & - & - \\
\hline AUM 1618 & 7.4 & 5.9 & 8.7 & 5.8 & 8.9 & 10.1 & 10.4 & 9.7 & 9.5 & 11.2 & 11.9 & 11.5 \\
\hline
\end{tabular}

\begin{tabular}{lcccccc}
\hline upper series & $\mathbf{L}_{\text {DPC }}$ & $\mathbf{L}_{\text {P2-M3 }}$ & \%DPC & L $_{\mathbf{P 2}-\mathbf{P 4}}$ & $\mathbf{L}_{\mathbf{M} 1-\mathbf{M} 3}$ & PMI \\
\hline AUM 231 & 17.0 & 51.3 & 33.1 & 20.5 & 31.2 & 65.7 \\
AUM 1544 r & 27.5 & 53.1 & 51.8 & $21.9(1)$ & 32.4 & 67.6 \\
AUM 1544 I & - & - & - & 22.2 & 32.0 & 69.4 \\
AUM 1552 & - & - & - & 22.6 & - & - \\
\hline
\end{tabular}


APPENDIX 5. - Continuation.

\begin{tabular}{|c|c|c|c|c|c|c|c|c|c|c|c|c|c|c|c|c|c|c|c|}
\hline \multirow[b]{2}{*}{ specimens } & \multicolumn{3}{|c|}{$\mathrm{P} / 2$} & \multicolumn{3}{|c|}{$\mathrm{P} / 3$} & \multicolumn{3}{|c|}{$\mathrm{P} / 4$} & \multicolumn{3}{|c|}{ M/1 } & \multicolumn{3}{|c|}{$M / 2$} & \multicolumn{4}{|c|}{$M / 3$} \\
\hline & $\mathbf{L}$ & W1 & W2 & $\mathbf{L}$ & W1 & W2 & $\mathbf{L}$ & W1 & W2 & $\mathbf{L}$ & W1 & W2 & $\mathbf{L}$ & W1 & W2 & $\mathbf{L}$ & W1 & W2 & W3 \\
\hline AUM 161 & - & - & - & - & - & - & - & - & - & 9.6 & 6.4 & 6.8 & 10.4 & 7.3 & 7.2 & 14.8 & 7.5 & 7.1 & 5.3 \\
\hline AUM 167 & 6.7 & 3.8 & 3.8 & - & - & - & - & - & - & - & - & - & - & - & - & - & - & - & - \\
\hline AUM 169 & - & - & - & - & - & - & - & - & - & 9.4 & 6.0 & 6.5 & 10.2 & 7.1 & 7.1 & 15.2 & 7.7 & 7.1 & 5.9 \\
\hline AUM 177 & - & - & - & - & - & - & - & - & - & 9.5 & 5.4 & 5.9 & - & - & - & - & - & - & - \\
\hline AUM 178 & - & - & - & 7.2 & 4.7 & 5.3 & - & - & - & - & - & - & - & - & - & - & - & - & - \\
\hline AUM 185 & - & - & - & - & - & - & - & - & - & - & - & - & 11.5 & 7.4 & 7.3 & - & - & - & - \\
\hline AUM 217 & - & - & - & - & - & - & - & - & - & - & - & - & 10.3 & 6.6 & 6.9 & - & - & - & - \\
\hline AUM 305 & - & - & - & - & - & - & - & - & - & - & - & - & 12.4 & 8.1 & 6.9 & - & - & - & - \\
\hline AUM 1556* & - & - & - & - & - & - & - & - & - & 8.3 & 6.0 & 6.3 & 9.9 & 6.4 & 6.5 & - & - & - & - \\
\hline AUM 1558 & - & - & - & - & - & - & - & - & - & - & - & - & 11.1 & 7.1 & 7.3 & - & - & - & - \\
\hline AUM 1559 & - & - & - & - & - & - & - & - & - & 9.0 & 5.9 & 6.0 & - & - & - & - & - & - & - \\
\hline AUM 1562 & 7.6 & 3.7 & 4.2 & - & - & - & - & - & - & - & - & - & - & - & - & - & - & - & - \\
\hline AUM 1568 & - & - & - & - & - & - & - & - & - & - & - & - & 9.6 & 6.1 & 6.6 & 13.4 & 6.2 & 5.6 & 4.3 \\
\hline AUM 1569 & - & - & - & - & - & - & - & - & - & - & - & - & - & - & - & 14.0 & 6.3 & 6.0 & 4.5 \\
\hline AUM 1570 & - & - & - & - & - & - & - & - & - & - & - & - & 9.4 & 6.2 & 6.5 & - & 6.3 & - & - \\
\hline AUM 1571 & - & - & - & - & - & - & - & - & - & - & - & - & - & - & - & 14.3 & 6.5 & 5.6 & 4.8 \\
\hline AUM 1575 & - & - & - & - & - & - & - & - & - & 8.9 & 5.9 & 6.0 & - & - & - & - & - & - & - \\
\hline AUM 1578 & - & - & - & 8.7 & 4.7 & 5.8 & - & - & - & - & - & - & - & - & - & - & - & - & - \\
\hline AUM 1579 & - & - & - & - & - & - & - & - & - & - & - & - & - & - & - & - & - & - & - \\
\hline AUM 1582 & - & - & - & - & - & - & - & - & - & 8.9 & 5.8 & 6.0 & - & - & - & - & - & - & - \\
\hline AUM 1605* & - & - & - & - & - & - & - & - & - & 10.2 & 6.5 & 6.8 & 11.7 & 7.7 & 7.8 & - & - & - & - \\
\hline AUM 1612 & 7.6 & 3.9 & 4.3 & - & - & - & - & - & - & - & - & - & - & - & - & - & - & - & - \\
\hline AUM 1621 & - & - & - & - & - & - & - & - & - & 9.0 & 5.9 & 5.9 & - & - & - & - & - & - & - \\
\hline AUM 1623 & - & - & - & - & - & - & - & - & - & 9.0 & 5.7 & 6.1 & - & - & - & - & - & - & - \\
\hline AUM 1629 & - & - & - & - & - & - & 9.3 & 5.8 & 6.2 & - & - & - & - & - & - & - & - & - & - \\
\hline AUM 1631 & - & - & - & - & - & - & - & - & - & - & - & - & - & - & - & - & 7.1 & 6.9 & - \\
\hline AUM 1635 & - & - & - & - & - & - & - & - & - & - & - & - & - & - & - & 13.5 & 6.4 & 5.6 & 4.5 \\
\hline AUM 1636 & - & - & - & - & - & - & 9.3 & 5.9 & 6.1 & - & - & - & - & - & - & - & - & - & - \\
\hline AUM 1637 & - & - & - & 8.5 & 4.3 & 5.2 & - & - & - & - & - & - & - & - & - & - & - & - & - \\
\hline AUM 1638 & - & - & - & - & - & - & - & - & - & - & - & - & - & - & - & 14.4 & 6.9 & 6.4 & 5.2 \\
\hline AUM 1639 & - & - & - & - & - & - & - & - & - & 8.3 & 5.8 & 5.5 & - & - & - & - & - & - & - \\
\hline AUM 1640 & - & - & - & - & - & - & 9.0 & 5.1 & 6.0 & - & - & - & - & - & - & - & - & - & - \\
\hline AUM 1641 & - & - & - & - & - & - & - & - & - & 9.6 & 6.0 & - & - & - & - & - & - & - & - \\
\hline AUM 1642 & - & - & - & - & - & - & 9.1 & 6.0 & 6.1 & - & - & - & - & - & - & - & - & - & - \\
\hline AUM 1643 & - & - & - & - & - & - & 8.3 & 5.8 & 5.5 & - & - & - & - & - & - & - & - & - & - \\
\hline AUM 1657 & - & - & - & - & - & - & - & - & - & - & - & - & 10.8 & 7.1 & 7.1 & - & - & - & - \\
\hline
\end{tabular}

\begin{tabular}{|c|c|c|c|c|c|c|c|c|c|}
\hline \multirow[b]{2}{*}{ specimens } & \multicolumn{3}{|c|}{ DP/2 } & \multicolumn{3}{|c|}{ DP/3 } & \multicolumn{3}{|c|}{ DP/4 } \\
\hline & $\mathbf{L}$ & W1 & W2 & $\mathbf{L}$ & W1 & W2 & $\mathbf{L}$ & W1 & W2 \\
\hline AUM 1549 & - & - & - & - & - & - & 8.4 & 5.2 & 5.6 \\
\hline AUM 1556* & - & - & - & 7.9 & 4.5 & 5.7 & - & 6.0 & - \\
\hline AUM 1605* & - & - & - & - & - & - & 8.7 & 5.4 & 5.9 \\
\hline AUM 1630 & - & - & - & - & - & - & 8.3 & 5.1 & 5.4 \\
\hline
\end{tabular}

\begin{tabular}{lcccccc}
\hline lower series & $\mathbf{L}_{\mathrm{DPC}}$ & $\mathbf{L}_{\mathbf{P 2}-\mathbf{M 3}}$ & $\%$ \%PC & $\mathbf{L}_{\mathbf{P 2}-\mathbf{P 4}}$ & $\mathbf{L}_{\mathbf{M 1}-\mathbf{M 3}}$ & PMI \\
\hline AUM 161 & $>23.0$ & 56.1 & $>41.0$ & $22.5(2)$ & 33.6 & 67.0 \\
AUM 169 & - & - & - & - & 34.8 & - \\
\hline
\end{tabular}


APPENDIX 6. - Measurements (in mm) of the cheek teeth specimens of Pachynolophus sp. from Aumelas (see synthetic Table 4). 1, LP2/assumed identical to that of AUM 1586; *, specimens provided with both permanent and milk teeth.

Pachynolophus sp. from Aumelas

\begin{tabular}{|c|c|c|c|c|c|c|c|c|c|c|c|c|c|c|c|c|c|c|}
\hline \multirow[b]{2}{*}{ specimens } & \multicolumn{2}{|c|}{ P2/ } & \multicolumn{2}{|c|}{ P3/ } & \multicolumn{2}{|c|}{ P4/ } & \multicolumn{4}{|c|}{ M1/ } & \multicolumn{4}{|c|}{ M2/ } & \multicolumn{4}{|c|}{ M3/ } \\
\hline & $\mathbf{L}$ & $\mathbf{W}$ & $\mathbf{L}$ & $\mathbf{W}$ & $\mathbf{L}$ & $\mathbf{W}$ & $\mathbf{L}$ & $\mathbf{W}$ & D & d & $\mathbf{L}$ & W & D & d & $\mathbf{L}$ & $\mathbf{W}$ & D & d \\
\hline AUM 199 & - & - & 8.2 & 10.3 & 8.2 & 11.7 & 10.8 & 14.2 & 14.8 & 14.3 & 13.6 & 16.2 & 17.9 & 16.1 & 14 & 16.1 & 17.3 & - \\
\hline AUM 213 & - & - & - & - & - & - & - & - & - & - & - & - & - & - & 14.1 & 16.8 & 17.1 & 16.3 \\
\hline AUM 1586 & 7.3 & 7.4 & 7.5 & 9.3 & 8.6 & 10.7 & 10.1 & - & - & 13.2 & - & - & - & - & - & - & - & - \\
\hline AUM 1596 & - & - & 7.4 & 10.8 & 8.6 & 11.8 & - & - & - & - & - & - & - & - & - & - & - & - \\
\hline AUM 1648 & - & - & - & - & 9.4 & 10.7 & - & - & - & - & - & - & - & - & - & - & - & - \\
\hline AUM 1649 & - & - & - & - & 9.4 & 11.3 & - & - & - & - & - & - & - & - & - & - & - & - \\
\hline
\end{tabular}

\begin{tabular}{lcccc}
\hline upper series & LP2-M3 & LP2-P4 & LM1-M3 & PMI \\
\hline AUM 199 & 60.6 & $24.3(1)$ & 36.3 & 67.1 \\
\hline
\end{tabular}

\begin{tabular}{|c|c|c|c|c|c|c|c|c|c|c|c|c|c|c|c|c|c|c|c|}
\hline \multirow[b]{2}{*}{ specimens } & \multicolumn{3}{|c|}{$\mathrm{P} / 2$} & \multicolumn{3}{|c|}{$P / 3$} & \multicolumn{3}{|c|}{$\mathrm{P} / 4$} & \multicolumn{3}{|c|}{$M / 1$} & \multicolumn{3}{|c|}{$M / 2$} & \multicolumn{4}{|c|}{ M/3 } \\
\hline & $\mathbf{L}$ & W1 & W2 & $\mathbf{L}$ & W1 & W2 & $\mathbf{L}$ & W1 & W2 & $\mathbf{L}$ & W1 & W2 & $\mathbf{L}$ & W1 & W2 & $\mathbf{L}$ & W1 & W2 & W3 \\
\hline AUM 162 & - & - & - & - & - & - & - & - & - & - & - & - & 11.7 & 8.2 & 8.5 & - & - & - & - \\
\hline AUM 167 & 6.7 & 3.8 & 3.8 & - & - & - & - & - & - & - & - & - & - & - & - & - & - & - & - \\
\hline AUM 227 & - & - & - & - & - & - & - & - & - & - & - & - & - & - & - & 17.4 & 9.2 & 7.9 & 5.8 \\
\hline AUM 1557 & - & - & - & - & - & - & - & - & - & - & - & - & - & - & - & 16.2 & 8.8 & 7.5 & 5.8 \\
\hline AUM 1599 & - & - & - & 8.6 & - & - & 8.6 & 6.7 & 6.8 & 9.8 & 7.8 & 8.1 & 11.5 & 9.1 & 8.7 & - & - & - & - \\
\hline AUM 1600 & - & - & - & - & - & - & - & - & - & - & - & - & 12.1 & 8.7 & 8.2 & 16.3 & 8.6 & 7.6 & 5.8 \\
\hline AUM 1602 & - & - & - & - & - & - & - & - & - & - & - & - & 12.0 & 8.1 & 7.9 & 17.8 & 8.5 & 7.8 & 5.7 \\
\hline AUM 1615 & - & - & - & - & - & - & 9.3 & 6.5 & 6.3 & 10.2 & 7.4 & 7.2 & 11.7 & 8.3 & 8.2 & 16.7 & 8.8 & 7.1 & 5.6 \\
\hline AUM 1616 & - & - & - & - & - & - & - & - & - & - & - & - & - & - & - & 17.9 & 8.8 & 8.3 & 6.6 \\
\hline AUM 1617* & - & - & - & - & - & - & - & - & - & 9.6 & 6.7 & 7.6 & 11.9 & 7.9 & 8.1 & 18.8 & 8.7 & 7.5 & 6.1 \\
\hline AUM 1620* & - & - & - & - & - & - & - & - & - & 10.0 & 7.2 & 7.9 & 12.0 & - & 8.3 & - & - & - & - \\
\hline AUM 1627 & - & - & - & - & - & - & - & - & - & - & - & - & 11.6 & 8.1 & 8.1 & 17.7 & 8.7 & 8.2 & 5.7 \\
\hline AUM 1654 & - & - & - & - & - & - & - & - & - & - & - & - & - & - & - & 16.4 & 8.6 & 7.4 & 6.1 \\
\hline
\end{tabular}

\begin{tabular}{|c|c|c|c|c|c|c|c|c|c|}
\hline \multirow[b]{2}{*}{ specimens } & \multicolumn{3}{|c|}{$\mathrm{DP} / 2$} & \multicolumn{3}{|c|}{$\mathrm{DP} / 3$} & \multicolumn{3}{|c|}{$\mathrm{DP} / 4$} \\
\hline & $\mathbf{L}$ & W1 & W2 & $\mathbf{L}$ & W1 & W2 & $\mathbf{L}$ & W1 & W2 \\
\hline AUM 332 & - & - & - & - & - & - & 10.3 & 5.5 & 5.9 \\
\hline AUM $1617^{*}$ & 7.4 & 3.1 & 3.7 & 8.4 & 4.6 & 5.6 & 9.1 & 6 & 6.5 \\
\hline AUM 1620* & 7.3 & 3.1 & 3.9 & 9.3 & 4.7 & 5.7 & 9.3 & 6.2 & 6.8 \\
\hline
\end{tabular}


APPENDIX 7. - Measurements (in mm) of the cheek teeth specimens of Lophiotherium sp. from Aumelas. (See synthetic Table 5); *, specimens provided with both permanent and milk teeth.

Lophiotherium sp. from Aumelas

\begin{tabular}{|c|c|c|c|c|c|c|c|c|c|c|c|c|}
\hline \multirow[b]{2}{*}{ specimens } & \multicolumn{4}{|c|}{ M1/ } & \multicolumn{4}{|c|}{ M2/ } & \multicolumn{4}{|c|}{ M3/ } \\
\hline & $\mathbf{L}$ & $\mathbf{W}$ & D & d & $\mathbf{L}$ & $\mathbf{W}$ & D & d & $\mathbf{L}$ & $\mathbf{W}$ & D & d \\
\hline AUM 172 & 6.8 & 8.6 & 9.1 & 8.2 & - & - & - & - & - & - & - & - \\
\hline AUM 232 & - & - & - & 8.0 & - & - & - & - & - & - & - & - \\
\hline AUM 234 & 6.9 & 7.6 & 8.1 & 7.6 & - & - & - & - & - & - & - & - \\
\hline AUM 1547 & - & - & - & - & - & - & - & 9.7 & - & - & - & - \\
\hline AUM 1626 & - & - & - & - & 7.6 & - & - & 9.7 & - & - & - & - \\
\hline AUM 1633 & - & - & - & - & - & - & - & - & 9.9 & 9.6 & 11.6 & 9.5 \\
\hline
\end{tabular}

\begin{tabular}{|c|c|c|c|c|c|c|c|c|c|c|c|c|c|c|c|c|}
\hline \multirow[b]{2}{*}{ specimens } & \multicolumn{3}{|c|}{$\mathrm{P} / 3$} & \multicolumn{3}{|c|}{$\mathrm{P} / 4$} & \multicolumn{3}{|c|}{$M / 1$} & \multicolumn{3}{|c|}{$M / 2$} & \multicolumn{4}{|c|}{$M / 3$} \\
\hline & $\mathbf{L}$ & W1 & W2 & $\mathbf{L}$ & W1 & W2 & $\mathbf{L}$ & W1 & W2 & $\mathbf{L}$ & W1 & W2 & $\mathbf{L}$ & W1 & W2 & W3 \\
\hline AUM 107* & - & - & - & - & - & - & 7.1 & - & - & 7.7 & - & - & 11.2 & 5.6 & - & - \\
\hline AUM 233 & - & - & - & - & - & - & 7.0 & 4.9 & 4.8 & - & - & - & - & - & - & - \\
\hline AUM 1548 & - & - & - & - & - & 4.3 & 7.7 & 5.0 & 5.4 & 8.4 & 5.8 & 5.8 & 12.2 & 5.9 & 5.0 & 4.1 \\
\hline AUM 1550 & - & - & - & - & - & - & - & - & - & 7.9 & 4.5 & 4.8 & - & - & - & - \\
\hline AUM 1551 & 7.0 & 3.7 & 4.1 & - & - & - & - & - & - & - & - & - & - & - & - & - \\
\hline AUM 1622 & - & - & - & - & - & - & 8.0 & 4.8 & 5.0 & - & - & - & - & - & - & - \\
\hline AUM 1624 & - & - & - & - & - & - & 7.7 & 4.5 & 5.0 & - & - & - & - & - & - & - \\
\hline
\end{tabular}

\begin{tabular}{|c|c|c|c|c|c|c|c|c|c|}
\hline \multirow[b]{2}{*}{ specimens } & \multicolumn{3}{|c|}{$\mathrm{DP} / 2$} & \multicolumn{3}{|c|}{$\mathrm{DP} / 3$} & \multicolumn{3}{|c|}{ DP/4 } \\
\hline & $\mathbf{L}$ & W1 & W2 & $\mathbf{L}$ & W1 & W2 & $\mathbf{L}$ & W1 & W2 \\
\hline AUM 107* & 5.2 & - & 2.9 & 7.2 & 3.7 & 4.2 & 7.2 & - & - \\
\hline AUM 170 & 5.6 & - & 2.8 & 7.3 & 3.3 & 3.8 & 6.6 & 4.2 & 4.5 \\
\hline
\end{tabular}

APPENDIX 8. - Estimated average weight of the species of Palaeotheriidae from Aumelas. The synthetic results correspond to the mediane of values calculated according to predictive equations of Janis (1990). The data provided correspond to the averages of the specimens concerned.

\begin{tabular}{|c|c|c|c|c|c|c|c|c|c|c|c|c|c|}
\hline \multirow{2}{*}{\multicolumn{2}{|c|}{$\begin{array}{l}\text { Predictive equations } \\
\text { (perissodactyls) }\end{array}$}} & \multirow[b]{2}{*}{ intercept } & \multirow[b]{2}{*}{ slope } & \multicolumn{2}{|c|}{$\begin{array}{c}\text { Propalaeo- } \\
\text { therium } \\
\text { sudrei }\end{array}$} & \multicolumn{2}{|c|}{$\begin{array}{c}\text { Propalaeo- } \\
\text { therium cf. } \\
\text { gaudryi }\end{array}$} & \multicolumn{2}{|c|}{$\begin{array}{c}\text { Pachynolophus } \\
\text { ruscassierensis } \\
\text { n. sp. }\end{array}$} & \multicolumn{2}{|c|}{$\begin{array}{c}\text { Pachynolophus } \\
\text { sp. }\end{array}$} & \multicolumn{2}{|c|}{$\begin{array}{c}\text { Lophiotherium } \\
\text { sp. }\end{array}$} \\
\hline & & & & $\begin{array}{l}\text { data } \\
(\mathrm{cm})\end{array}$ & $\begin{array}{l}\text { Estim. } \\
\text { weight }\end{array}$ & $\begin{array}{l}\text { data } \\
(\mathrm{cm})\end{array}$ & $\begin{array}{l}\text { Estim. } \\
\text { weight }\end{array}$ & $\begin{array}{l}\text { data } \\
(\mathrm{cm})\end{array}$ & $\begin{array}{l}\text { Estim. } \\
\text { weight }\end{array}$ & $\begin{array}{l}\text { data } \\
(\mathrm{cm})\end{array}$ & $\begin{array}{l}\text { Estim. } \\
\text { weight }\end{array}$ & $\begin{array}{l}\text { data } \\
(\mathrm{cm})\end{array}$ & $\begin{array}{l}\text { Estim. } \\
\text { weight }\end{array}$ \\
\hline $\mathrm{P} / 2$ length & SLPL & 1.527 & 2.637 & 0.70 & 13 & 0.87 & 23 & 0.73 & 15 & 0.67 & 12 & - & - \\
\hline P/2 width & SLPW & 2.275 & 2.739 & 0.38 & 13 & 0.52 & 31 & 0.41 & 16 & 0.38 & 13 & - & - \\
\hline $\mathrm{P} / 3$ length & TLPL & 1.383 & 2.965 & 0.79 & 12 & 0.93 & 19 & 0.81 & 13 & 0.86 & 15 & 0.70 & 8 \\
\hline P/3 width & TLPW & 2.09 & 2.753 & 0.52 & 20 & 0.63 & 34 & 0.54 & 23 & - & - & 0.41 & 11 \\
\hline $\mathrm{P} / 4$ length & FLPL & 1.29 & 3.09 & 0.90 & 14 & 0.93 & 16 & 0.90 & 14 & 0.90 & 14 & - & - \\
\hline P/4 width & FLPW & 1.965 & 2.854 & 0.63 & 25 & 0.69 & 32 & 0.60 & 21 & 0.66 & 28 & 0.43 & 8 \\
\hline $\mathrm{M} / 1$ length & FLML & 1.264 & 3.187 & 1.01 & 19 & 1.07 & 23 & 0.91 & 14 & 0.99 & 18 & 0.75 & 7 \\
\hline M/1 width & FLMW & 1.94 & 2.856 & 0.74 & 37 & 0.76 & 40 & 0.62 & 22 & 0.77 & 41 & 0.51 & 13 \\
\hline M/2 length & SLML & 1.216 & 3.01 & 1.15 & 25 & 1.22 & 30 & 1.07 & 20 & 1.18 & 27 & 0.80 & 8 \\
\hline $\mathrm{M} / 2$ width & SLMW & 1.873 & 2.91 & 0.81 & 40 & 0.87 & 50 & 0.70 & 26 & 0.83 & 43 & 0.53 & 12 \\
\hline $\mathrm{M} / 3$ length & TLML & 1.162 & 2.999 & 1.61 & 61 & 1.77 & 80 & 1.42 & 42 & 1.72 & 74 & 1.17 & 23 \\
\hline $\mathrm{M} / 3$ width & TLMW & 2.001 & 2.941 & 0.83 & 58 & 0.85 & 62 & 0.68 & 32 & 0.87 & 67 & 0.58 & 20 \\
\hline M2/ length & SUML & 1.209 & 2.9 & 1.19 & 27 & 1.29 & 34 & 1.09 & 21 & 1.36 & 39 & 0.76 & 7 \\
\hline M2/ width & SUMW & 1.345 & 2.887 & 1.40 & 58 & 1.55 & 78 & 1.29 & 46 & 1.62 & 89 & - & - \\
\hline M2/ area & SUMA & 1.27 & 1.456 & 1.23 & 25 & 1.57 & 36 & 1.07 & 21 & 1.75 & 42 & - & - \\
\hline $\begin{array}{l}\text { length of lower } \\
\text { premolar row }\end{array}$ & LPRL & 0.026 & 2.865 & 2.38 & 13 & - & - & 2.25 & 11 & 2.25 & 11 & - & - \\
\hline $\begin{array}{l}\text { length of lower } \\
\text { molar row }\end{array}$ & LMRL & -0.246 & 3.061 & 3.77 & 33 & 4.11 & 43 & 3.42 & 24 & 3.42 & 24 & 2.79 & 13 \\
\hline $\begin{array}{l}\text { total length of the } \\
\text { mandible }\end{array}$ & TJL & -1.384 & 2.564 & - & - & - & - & - & - & - & - & - & - \\
\hline basicranial length & TSL & -1.931 & 2.751 & - & - & - & - & - & - & - & - & - & - \\
\hline \multicolumn{4}{|c|}{ estimated average weight (kg) } & \multicolumn{2}{|c|}{25} & \multicolumn{2}{|c|}{34} & \multicolumn{2}{|c|}{21} & \multicolumn{2}{|c|}{28} & \multicolumn{2}{|c|}{11} \\
\hline
\end{tabular}


APPENDIX 9. - Upper cheek teeth surfaces (in mm2) of the Propalaeotherium from Aumelas and of some other propalaeotheres. In bold, variation ranges (surfaces) and means (aggregate measures and ratios).

\begin{tabular}{|c|c|c|c|c|c|c|c|c|c|c|c|c|c|c|}
\hline \multirow[b]{2}{*}{ Specimens } & \multicolumn{6}{|c|}{ Surfaces } & \multicolumn{3}{|c|}{ Aggregate measures } & \multicolumn{5}{|c|}{ Ratios } \\
\hline & P2/ & P3/ & P4/ & M1/ & M2/ & M3/ & $S_{P 2-M^{3}}$ & $\mathrm{~S}_{\mathrm{P} 2-\mathrm{P} 4}$ & $\mathrm{~S}_{\mathrm{M1}-\mathrm{M} 3}$ & $\mathrm{~S}_{\mathrm{M} 3} / \mathrm{S}_{\mathrm{M} 1}$ & $\mathrm{~S}_{\mathrm{P}} / \mathrm{S}_{\mathrm{M}}$ & $\mathrm{S}_{\mathrm{P} 4} / \mathrm{S}_{\mathrm{M} 3}$ & $\mathrm{~S}_{\mathrm{P} 4} / \mathrm{S}_{\mathrm{M}}$ & $\mathrm{S}_{\mathrm{P} 2-\mathrm{P} 3} / \mathrm{S}_{\mathrm{M}}$ \\
\hline \multicolumn{15}{|c|}{ Propalaeotherium sudrei Remy, Krasovec \& Marandat, 2016} \\
\hline $\mathrm{N}$ & 1 & 2 & 2 & 6 & 4 & 2 & - & - & - & - & - & - & - & - \\
\hline mean & 32.1 & 51.9 & 70.5 & 101.8 & 122.9 & 126.2 & 505.4 & 154.5 & 350.9 & 123.9 & 44.0 & 55.9 & 20.1 & 23.9 \\
\hline $\begin{array}{l}\text { standard } \\
\text { deviation }\end{array}$ & - & - & - & 9.914 & 5.436 & - & - & - & - & - & - & - & - & - \\
\hline $\begin{array}{l}\text { coeff. of } \\
\text { variation }\end{array}$ & - & - & - & 9.7 & 4.4 & - & - & - & - & - & - & - & - & - \\
\hline AUM 181 & 32.1 & 49.4 & 64.5 & 94.0 & 119.1 & 124.9 & 484.0 & 145.9 & 338.1 & 132.9 & 43.2 & 51.6 & 19.1 & 24.1 \\
\hline AUM 173 & - & - & - & 107.6 & - & - & - & - & - & - & - & - & - & - \\
\hline AUM 174 & - & - & - & 87.7 & - & - & - & - & - & - & - & - & - & - \\
\hline AUM 175 & - & - & 76.5 & 98.9 & 126.2 & 127.4 & - & - & - & - & - & 60.1 & 21.7 & - \\
\hline AUM 201 & - & - & - & 110.0 & 128.8 & - & - & - & - & - & - & - & - & - \\
\hline AUM 202 & - & - & - & - & 117.5 & - & - & - & - & - & - & - & - & - \\
\hline AUM 207 & - & 54.5 & - & - & - & - & - & - & - & - & - & - & - & - \\
\hline AUM 221 & - & - & - & 112.9 & - & - & - & - & - & - & - & - & - & - \\
\hline
\end{tabular}

Propalaeotherium cf. gaudryi from Aumelas

\begin{tabular}{|c|c|c|c|c|c|c|c|c|c|c|c|c|c|c|}
\hline $\begin{array}{l}\mathrm{N} \\
\text { mean }\end{array}$ & 3 & 3 & $\begin{array}{c}3 \\
912\end{array}$ & $\begin{array}{c}4 \\
1318\end{array}$ & $\begin{array}{c}6 \\
1558\end{array}$ & $\begin{array}{c}7 \\
1670\end{array}$ & - & - & $\overline{4546}$ & $12 \overline{-}$ & $\overline{44}$ & - & $\overline{201}$ & 243 \\
\hline $\begin{array}{l}\text { standard } \\
\text { deviation }\end{array}$ & 1.763 & 6.003 & 1.653 & 7.009 & 14.036 & 12.738 & - & - & - & - & - & - & - & - \\
\hline $\begin{array}{l}\text { coeff. of } \\
\text { variation }\end{array}$ & 4.2 & 8.7 & 1.8 & 5.3 & 9.0 & 7.6 & - & - & - & - & - & - & - & - \\
\hline AUM 047 & - & - & - & - & - & 163.8 & - & - & - & - & - & - & - & - \\
\hline AUM 164 & - & - & - & - & - & 162.1 & - & - & - & - & - & - & - & - \\
\hline AUM 168 & 43.5 & 71.9 & 90.6 & 129.2 & 133.8 & 147.6 & 616.5 & 206.0 & 410.5 & 114.2 & 50.2 & 61.4 & 22.1 & 28.1 \\
\hline AUM 209 & - & - & - & 125.3 & 172.8 & 163.5 & - & - & 461.5 & 130.5 & - & - & - & - \\
\hline AUM 1583 & 40.0 & 72.8 & 93.1 & 141.7 & 164.1 & 165.6 & 677.2 & 205.9 & 471.3 & 116.9 & 43.7 & 56.2 & 19.8 & 23.9 \\
\hline AUM 1584 & 41.8 & 62.0 & 90.0 & 131.2 & 160.5 & 180.2 & 665.8 & 193.8 & 472.0 & 137.3 & 41.1 & 49.9 & 19.1 & 22.0 \\
\hline AUM 1590 & - & - & - & - & - & 186.3 & - & - & - & - & - & - & - & - \\
\hline AUM 1592 & - & - & - & - & 145.2 & - & - & - & - & - & - & - & - & - \\
\hline AUM 1595 & - & - & - & - & 158.6 & - & - & - & - & - & - & - & - & - \\
\hline
\end{tabular}

Eurohippus parvulus messelensis

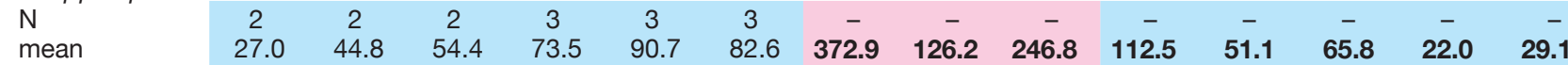
standard

deviation

coeff. of

variation

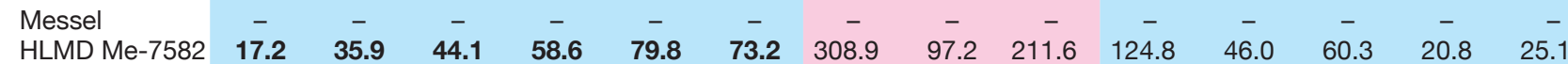
HLMD Me-58c $\begin{array}{lccccccccccccc}\text { Geiseltal } & - & - & - & - & - & - & - & - & - & - & - & - & - \\ -\end{array}$

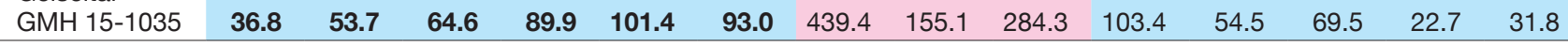

Eurohippus parvulus parvulus

\begin{tabular}{lcccccccccccccc}
$N$ & 2 & 5 & 4 & 5 & 5 & 5 & - & - & - & - & - & - & - & - \\
mean & 36.3 & 52.0 & 67.6 & 90.4 & 97.0 & 95.3 & $\mathbf{4 3 8 . 6}$ & $\mathbf{1 5 6 . 0}$ & $\mathbf{2 8 2 . 7}$ & $\mathbf{1 0 5 . 4}$ & $\mathbf{5 5 . 2}$ & $\mathbf{7 1 . 0}$ & $\mathbf{2 3 . 9}$ & $\mathbf{3 1 . 2}$ \\
$\begin{array}{c}\text { standard } \\
\text { deviation }\end{array}$ & - & 2.909 & 6.199 & 13.189 & 12.037 & 12.733 & - & - & - & - & - & - & - & - \\
$\begin{array}{c}\text { coeff. of } \\
\text { variation }\end{array}$ & - & 5.6 & 9.2 & 14.6 & 12.4 & 13.4 & - & - & - & - & - & - & - & - \\
\hline
\end{tabular}

Geiseltal

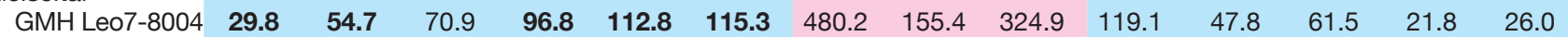

Egerkingen

NMB Eb-10

NMB Eb-276

NMB Eb-200

NMB Eb-421

NMB Eb-413

NMB Eb-323

NMB Eb-428

NMB Eb-306

NMB Eb-344

NMB Eb-381

NMB Eb-74a

NMB Eh-333

NMB Eh-792

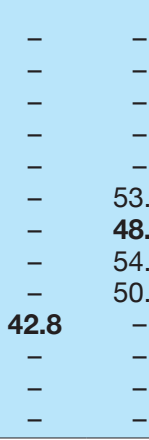

$\begin{array}{cccccc}- & - & 76.2 & 92.6 & 92.9 & - \\ - & - & - & - & 80.6 & - \\ - & - & - & 81.6 & - & - \\ - & 63.1 & - & - & - & - \\ - & 74.8 & - & - & - & - \\ 53.0 & - & - & - & - & - \\ 48.1 & - & - & - & - & - \\ 54.4 & - & - & - & - & - \\ 50.0 & - & - & - & - & - \\ - & - & - & - & - & - \\ - & - & 109.9 & - & - & - \\ - & - & 86.4 & 104.6 & 90.4 & - \\ - & 61.9 & 82.7 & 93.4 & 97.3 & -\end{array}$

$\begin{array}{ccc}- & - & 261.7 \\ - & - & - \\ - & - & - \\ - & - & - \\ - & - & - \\ - & - & - \\ - & - & - \\ - & - & - \\ - & - & - \\ - & - & - \\ - & - & - \\ - & - & 281.4 \\ - & - & 273.4\end{array}$

$\begin{array}{lllll}- & - & - & - & - \\ - & - & - & - & - \\ - & - & - & - & - \\ - & - & - & - & - \\ - & - & - & - & - \\ - & - & - & - & - \\ - & - & - & - & - \\ - & - & - & - & - \\ - & - & - & - & - \\ - & - & - & - & - \\ - & - & - & - & - \\ - & - & - & - & - \\ - & - & 63.6 & 22.6 & -\end{array}$




\begin{tabular}{|c|c|c|c|c|c|c|c|c|c|c|c|c|c|c|}
\hline \multirow[b]{2}{*}{ Specimens } & \multicolumn{6}{|c|}{ Surfaces } & \multicolumn{3}{|c|}{ Aggregate measures } & \multicolumn{5}{|c|}{ Ratios } \\
\hline & P2/ & P3/ & P4/ & M1/ & M2/ & M3/ & $S_{P 2-M^{3}}$ & $\mathrm{~S}_{\mathrm{P2}-\mathrm{P} 4}$ & $\mathrm{~S}_{\mathrm{M1}-\mathrm{M} 3}$ & $\mathrm{~S}_{\mathrm{M} 3} / \mathrm{S}_{\mathrm{M} 1}$ & $\mathrm{~S}_{\mathrm{P}} / \mathrm{S}_{\mathrm{M}}$ & $\mathrm{S}_{\mathrm{P} 4} / \mathrm{S}_{\mathrm{M} 3}$ & $\mathrm{~S}_{\mathrm{P} 4} / \mathrm{S}_{\mathrm{M}}$ & $\mathrm{S}_{\mathrm{P} 2-\mathrm{P} 3} / \mathrm{S}_{\mathrm{M}}$ \\
\hline \multicolumn{15}{|c|}{ Eurohippus parvulus from Robiac } \\
\hline $\begin{array}{l}\mathrm{N} \\
\text { mean }\end{array}$ & $\begin{array}{c}1 \\
26.6 \\
\end{array}$ & $\begin{array}{c}2 \\
43.7\end{array}$ & $\begin{array}{c}2 \\
61.4\end{array}$ & $\begin{array}{c}2 \\
75.0\end{array}$ & $\begin{array}{c}2 \\
90.9\end{array}$ & $\begin{array}{c}2 \\
91.8\end{array}$ & $38 \overline{9}$ & 131.7 & 257.7 & $12 \overline{2} .3$ & $\overline{51.1}$ & $\overline{-}$ & $-\overline{23.8}$ & $\begin{array}{c}- \\
27.3\end{array}$ \\
\hline $\begin{array}{l}\text { UM-RbN } 5681 \\
\text { UM-RbN 5969a }\end{array}$ & $-\overline{26.6}$ & $\begin{array}{l}41.5 \\
45.9\end{array}$ & $\begin{array}{l}59.8 \\
63.1\end{array}$ & $\begin{array}{l}78.3 \\
71.8 \\
\end{array}$ & $\begin{array}{l}94.4 \\
87.3\end{array}$ & $\begin{array}{l}96.7 \\
86.9\end{array}$ & $\begin{array}{c}- \\
381.6 \\
\end{array}$ & 135.6 & $\begin{array}{l}269.4 \\
246.0\end{array}$ & $\begin{array}{l}123.5 \\
121.0\end{array}$ & - & $\begin{array}{l}61.8 \\
72.6 \\
\end{array}$ & $\begin{array}{l}22.2 \\
25.6\end{array}$ & 29.5 \\
\hline \multicolumn{15}{|c|}{ Propalaeotherium gaudryi } \\
\hline & $\begin{array}{c}3 \\
41.2\end{array}$ & $\begin{array}{c}3 \\
69.1\end{array}$ & $\begin{array}{c}3 \\
86.3\end{array}$ & $\begin{array}{c}3 \\
124.3\end{array}$ & $\begin{array}{c}3 \\
162.8\end{array}$ & $\begin{array}{c}3 \\
167.7\end{array}$ & $\frac{-}{651.5}$ & 196.7 & $45 \overline{4.9}$ & $13 \overline{4} .9$ & 130.9 & $-\overline{48.3}$ & $-\overline{23.1}$ & 24.3 \\
\hline $\begin{array}{l}\text { standard } \\
\text { deviation }\end{array}$ & 8.870 & 2.985 & 7.800 & 4.156 & 6.322 & 10.933 & - & - & - & - & - & - & - & - \\
\hline $\begin{array}{c}\text { coeff. of } \\
\text { variation }\end{array}$ & 21.5 & 4.3 & 9.0 & 3.3 & 3.9 & 6.5 & - & - & - & - & - & - & - & - \\
\hline NMB TS-83 & 36.5 & 69.1 & 85.6 & 129.0 & 169.6 & 173.6 & 663.4 & 191.2 & 472.2 & 134.5 & 40.5 & 49.3 & 18.1 & 22.4 \\
\hline NMB 2096 & 35.8 & 66.2 & 78.8 & 121.2 & 157.1 & 155.1 & 614.2 & 180.8 & 433.4 & 128.0 & 41.7 & 50.8 & 18.2 & 23.5 \\
\hline $\begin{array}{l}\text { MNHN } \\
\text { MA-14948 }\end{array}$ & 51.5 & 72.2 & 94.4 & 122.8 & 161.7 & 174.5 & 676.96 & 218.02 & 458.9 & 142.1 & 310.5 & 44.6 & 33.1 & 26.9 \\
\hline
\end{tabular}

Propalaeotherium hassiacum

\begin{tabular}{|c|c|c|c|c|c|c|c|c|c|c|c|c|c|c|}
\hline $\begin{array}{l}\mathrm{N} \\
\text { mean }\end{array}$ & $\begin{array}{c}5 \\
53.8\end{array}$ & $\begin{array}{c}5 \\
96.4\end{array}$ & $\begin{array}{c}5 \\
118.9\end{array}$ & $\begin{array}{c}5 \\
167.2\end{array}$ & $\begin{array}{c}5 \\
210.7\end{array}$ & $\begin{array}{c}5 \\
207.3\end{array}$ & $85 \overline{4.3}$ & $26 \overline{-1}$ & $58 \overline{5.2}$ & $12 \overline{-} .0$ & $4 \overline{6.0}$ & - & $2 \overline{0.3}$ & 25.7 \\
\hline $\begin{array}{l}\text { standard } \\
\text { deviation }\end{array}$ & 6.359 & 11.258 & 9.036 & 9.211 & 17.163 & 20.577 & - & - & - & - & - & - & - & - \\
\hline $\begin{array}{l}\text { coeff. of } \\
\text { variation }\end{array}$ & 11.8 & 11.7 & 7.6 & 5.5 & 8.1 & 9.9 & - & - & - & - & - & - & - & - \\
\hline GMH 14-1311 & 48.9 & 106.9 & 117.4 & 161.6 & 220.9 & 207.6 & 863.3 & 273.2 & 590.1 & 128.5 & 46.3 & 56.5 & 19.9 & 26.4 \\
\hline GMH 14-2175 & 58.5 & 89.4 & 107.5 & 154.4 & 180.5 & 175.2 & 765.6 & 255.4 & 510.1 & 113.5 & 50.1 & 61.3 & 21.1 & 29.0 \\
\hline GMH 14-2338 & 61.7 & 101.6 & 116.3 & 176.3 & 215.1 & 209.2 & 880.2 & 279.6 & 600.6 & 118.7 & 46.6 & 55.6 & 19.4 & 27.2 \\
\hline GMH 14-4007 & 46.5 & 80.1 & 120.9 & 174.8 & 215.0 & 232.6 & 870.0 & 247.5 & 622.4 & 133.1 & 39.8 & 52.0 & 19.4 & 20.4 \\
\hline GMH 14-4174 & 53.5 & 104.0 & 132.4 & 169.2 & 221.8 & 211.9 & 892.7 & 289.9 & 602.8 & 125.2 & 48.1 & 62.5 & 22.0 & 26.1 \\
\hline
\end{tabular}

Propalaeotherium voigti (Geiseltal MK)

\begin{tabular}{lcccccccccccccc} 
N & 2 & 2 & 2 & 2 & 2 & 2 & - & - & - & - & - & - & - & - \\
mean & 36.2 & 59.3 & 79.8 & 113.9 & 138.3 & 143.5 & $\mathbf{5 7 0 . 9}$ & $\mathbf{1 7 5 . 2}$ & $\mathbf{3 9 5 . 6}$ & $\mathbf{1 2 6 . 0}$ & $\mathbf{4 4 . 3}$ & $\mathbf{5 5 . 6}$ & $\mathbf{2 0 . 2}$ & $\mathbf{2 4 . 1}$ \\
\hline GMH 6-10288 & $\mathbf{4 0 . 4}$ & $\mathbf{5 7 . 7}$ & $\mathbf{8 7 . 3}$ & $\mathbf{1 2 2 . 2}$ & $\mathbf{1 5 0 . 7}$ & $\mathbf{1 5 4 . 1}$ & 612.4 & 185.4 & 427.1 & 126.1 & 43.4 & 56.7 & 20.5 & 23.0 \\
GMH 37-161 & $\mathbf{3 2 . 0}$ & $\mathbf{6 0 . 9}$ & $\mathbf{7 2 . 2}$ & $\mathbf{1 0 5 . 5}$ & $\mathbf{1 2 5 . 8}$ & $\mathbf{1 3 2 . 9}$ & 529.3 & 165.1 & 364.2 & 126.0 & 45.3 & 54.3 & 19.8 & 25.5
\end{tabular}

Propalaeotherium cf. voigti (Geiseltal uUK)

\begin{tabular}{lrrrrrrrrrrrrrr} 
N & 2 & 2 & 2 & 2 & 2 & 1 & - & - & - & - & - & - & - & - \\
mean & 47.4 & 78.3 & 95.8 & 136.2 & 148.8 & 155.1 & $\mathbf{6 6 1 . 6}$ & $\mathbf{2 2 1 . 4}$ & $\mathbf{4 4 0 . 2}$ & $\mathbf{1 1 3 . 9}$ & $\mathbf{5 0 . 3}$ & $\mathbf{6 1 . 7}$ & $\mathbf{2 1 . 8}$ & $\mathbf{2 8 . 5}$ \\
\hline GMH 14-3347 & $\mathbf{4 7 . 5}$ & $\mathbf{7 7 . 5}$ & $\mathbf{1 0 3 . 7}$ & $\mathbf{1 4 2 . 2}$ & $\mathbf{1 6 5 . 3}$ & $\mathbf{1 5 5 . 1}$ & 691.4 & 228.8 & 462.6 & 109.1 & 49.4 & 66.9 & 22.4 & 27.0 \\
GMH 14-3428 & $\mathbf{4 7 . 3}$ & $\mathbf{7 9 . 0}$ & $\mathbf{8 7 . 8}$ & $\mathbf{1 3 0 . 2}$ & $\mathbf{1 3 2 . 3}$ & - & - & - & - & - & - & - & - & - \\
\hline
\end{tabular}

Propalaeotherium isselanum

$\begin{array}{lcccccccccccccc}\text { N } & 1 & 1 & 2 & 2 & 2 & 2 & - & - & - & - & - & - & - & - \\ \text { mean } & 83.2 & 127.9 & 142.3 & 188.8 & 227.9 & 242.5 & \mathbf{1 0 1 2 . 5} & \mathbf{3 5 3 . 3} & \mathbf{6 5 9 . 2} & \mathbf{1 2 8 . 4} & \mathbf{5 3 . 6} & \mathbf{5 8 . 7} & \mathbf{2 1 . 6} & \mathbf{3 2 . 0} \\ \text { MNHN EBA- } & \mathbf{8 3 . 2} & \mathbf{1 2 7 . 9} & \mathbf{1 4 9 . 8} & \mathbf{2 0 1 . 5} & \mathbf{2 5 1 . 6} & \mathbf{2 5 3 . 7} & 1067.6 & 360.9 & 706.7 & 125.9 & 51.1 & 59.0 & 21.2 & 29.9 \\ \quad \text { 509 } & & & & & & & & & & & & & & \\ \text { MNHN EBA- } & - & - & \mathbf{1 3 4 . 7} & \mathbf{1 7 6 . 2} & \mathbf{2 0 4 . 1} & \mathbf{2 3 1 . 3} & - & - & \mathbf{6 1 1 . 6} & \mathbf{1 3 1 . 3} & - & 58.2 & 22.0 & - \\ \quad 508 & & & & & & & & & & & & & \end{array}$

Propalaeotherium "isselanum" (Geiseltal oMK)

\begin{tabular}{|c|c|}
\hline GMH 36-528 & 58.0 \\
\hline
\end{tabular}


APPENDIX 10. - Comparison of upper cheek teeth surfaces of the Propalaeotherium from Aumelas with various propalaeotheres. Significance probabilities established from Student's t-test (id. for all other Appendices). In bold, significant tests.

\begin{tabular}{|c|c|c|c|c|c|c|c|c|c|c|}
\hline & \multicolumn{6}{|c|}{ Surfaces } & \multicolumn{3}{|c|}{$\begin{array}{l}\text { Aggregate measures } \\
\text { (ratios) }\end{array}$} & \multirow{2}{*}{$\frac{\text { Overall }}{\text { means }}$} \\
\hline & P2/ & P3/ & P4/ & M1/ & M2/ & M3/ & $\mathrm{S}_{\mathrm{P} 2-\mathrm{M} 3}$ & $\mathrm{~S}_{\mathrm{P} 2-\mathrm{P} 4}$ & $S_{M 1-M 3}$ & \\
\hline \multicolumn{11}{|c|}{ comparing Propalaeotherium sudrei vs Eurohippus parvulus messelensis } \\
\hline degree of freedom & 1 & 2 & 2 & 7 & 5 & 3 & - & - & - & - \\
\hline t (sudrei/messelensis) & 0.2996 & 0.7735 & 1.3553 & 3.3848 & 5.2652 & 5.8359 & - & - & - & - \\
\hline signification & NS & NS & NS & 95 & 99 & 98 & - & - & - & - \\
\hline surface ratio (from means) & 118.8 & 116.0 & 129.7 & 138.6 & 135.6 & 152.7 & 135.5 & 122.5 & 142.2 & 132.4 \\
\hline
\end{tabular}

comparing Propalaeotherium sudrei vs Eurohippus parvulus parvulus

\begin{tabular}{|c|c|c|c|c|c|c|c|c|c|c|}
\hline degree of freedom & 1 & 5 & 4 & 9 & 7 & 5 & - & - & - & - \\
\hline t (sudrei/parvulus parvulus) & -0.3738 & -0.0480 & 0.4838 & 1.6468 & 3.9556 & 3.2303 & - & - & - & - \\
\hline signification & NS & NS & NS & NS & 99 & 95 & - & - & - & - \\
\hline surface ratio (from means) & 88.4 & 99.8 & 104.2 & 112.7 & 126.7 & 132.4 & 115.2 & 99.1 & 124.1 & 111.4 \\
\hline
\end{tabular}

comparing Propalaeotherium sudrei vs Pr. gaudryi

\begin{tabular}{|c|c|c|c|c|c|c|c|c|c|c|}
\hline degree of freedom & 2 & 3 & 3 & 7 & 5 & 3 & - & - & - & - \\
\hline t (sudrei/gaudryi) & -0.8950 & -0.9122 & -0.3564 & -1.9453 & -2.3235 & -0.9370 & - & - & - & - \\
\hline signification & NS & NS & NS & -90 & -90 & NS & - & - & - & - \\
\hline surface ratio (from means) & 77.8 & 75.1 & 81.7 & 81.9 & 75.5 & 75.2 & 77.6 & 78.6 & 77.1 & 77.8 \\
\hline
\end{tabular}

comparing Propalaeotherium cf. gaudryi from Aumelas vs Pr. sudrei

\begin{tabular}{|c|c|c|c|c|c|c|c|c|c|c|}
\hline degree of freedom & 2 & 3 & 3 & 8 & 8 & 7 & - & - & - & - \\
\hline t (cf. gaudryi/sudrei) & 4.7809 & 3.4867 & 4.4500 & 5.1983 & 4.3994 & 4.3132 & - & - & - & - \\
\hline signification & 95 & 95 & 95 & 99.9 & 99 & 99 & - & - & - & - \\
\hline surface ratio (from means) & 130.3 & 132.6 & 129.4 & 129.4 & 126.8 & 132.4 & 129.9 & 130.7 & 129.6 & 130.1 \\
\hline
\end{tabular}

comparing Propalaeotherium cf. gaudryi from Aumelas vs Pr. gaudryi

\begin{tabular}{|c|c|c|c|c|c|c|c|c|c|c|}
\hline degree of freedom & 4 & 4 & 4 & 5 & 7 & 8 & - & - & - & - \\
\hline t (cf. gaudryi/gaudryi) & 0.1082 & -0.0715 & 1.0809 & 1.6292 & -0.8036 & -0.0858 & - & - & - & - \\
\hline signification & NS & NS & NS & NS & NS & NS & - & - & - & - \\
\hline surface ratio (from means) & 101.4 & 99.6 & 105.8 & 106.0 & 95.7 & 99.6 & 100.8 & 102.7 & 99.9 & 101.3 \\
\hline
\end{tabular}

comparing Propalaeotherium cf. gaudryi from Aumelas vs Pr. hassiacum

\begin{tabular}{|c|c|c|c|c|c|c|c|c|c|c|}
\hline degree of freedom & 6 & 6 & 6 & 7 & 9 & 10 & - & - & - & - \\
\hline t (cf. gaudryi/hassiacum) & -3.1161 & -3.8374 & -5.0870 & -6.3308 & -5.8430 & -4.2161 & - & - & - & - \\
\hline signification & -95 & -99 & -99 & -99.9 & -99.9 & -99 & - & - & - & - \\
\hline e ratio (from means) & 77.6 & 71.4 & 76.8 & 78.8 & 74.0 & 80.6 & 76.8 & 75.0 & 77.7 & 76.5 \\
\hline
\end{tabular}

comparing Propalaeotherium cf. gaudryi from Aumelas vs Pr. voigti (Geiseltal MK)

\begin{tabular}{|c|c|c|c|c|c|c|c|c|c|c|}
\hline degree of freedom & 3 & 3 & 3 & 4 & 6 & 7 & - & - & - & - \\
\hline t (cf. gaudryi/voigti) & 1.6562 & 2.0686 & 1.9875 & 2.4474 & 1.4615 & 2.2410 & - & - & - & - \\
\hline signification & NS & NS & NS & 90 & NS & 90 & - & - & - & - \\
\hline surface ratio (from means) & 115.5 & 116.2 & 114.4 & 115.8 & 112.7 & 116.4 & 115.0 & 115.2 & 114.9 & 115.1 \\
\hline
\end{tabular}

comparing Propalaeotherium cf. gaudryi from Aumelas vs Pr. cf. voigti (Geiseltal uUK)

\begin{tabular}{|c|c|c|c|c|c|c|c|c|c|c|}
\hline degree of freedom & 3 & 3 & 3 & 4 & 6 & 6 & - & - & - & - \\
\hline gaudryi/cf. voigti) & -4.2416 & -2.0842 & -0.7429 & -0.6857 & 0.5367 & 0.8713 & - & - & - & - \\
\hline fication & -95 & NS & NS & NS & NS & NS & - & - & - & - \\
\hline ratio (from means) & 88.2 & 88.0 & 95.3 & 96.8 & 104.7 & 107.6 & 99.2 & 91.2 & 103.3 & 97.1 \\
\hline
\end{tabular}

comparing Propalaeotherium cf. gaudryi from Aumelas vs Pr. isselanum

\begin{tabular}{|c|c|c|c|c|c|c|c|c|c|c|}
\hline degree of freedom & 2 & 2 & 3 & 4 & 6 & 7 & - & - & - & - \\
\hline t (cf. gaudryi/isselanum) & -20.353 & -8.5101 & -8.8758 & -6.0932 & -4.7026 & -7.1248 & - & - & - & - \\
\hline signification & -99 & -98 & -99 & -99 & -99 & -99.9 & - & - & - & - \\
\hline surface ratio (from means) & 50.2 & 53.9 & 64.1 & 69.8 & 68.4 & 68.9 & 64.8 & 57.1 & 69.0 & 62.9 \\
\hline
\end{tabular}

surface ratio (from means) 
APPENDIX 11. - Comparisons between lower cheek teeth surfaces (in mm2: $L \times W_{\max }$ ) in Propalaeotherium sudrei Remy, Krasovec \& Marandat, 2016 and Pr. cf. gaudryi from Aumelas. Bold, variation ranges. Significance probabilities are established from Student's t-test.

\begin{tabular}{|c|c|c|c|c|c|c|}
\hline & \multicolumn{6}{|c|}{$\mathbf{L} \times \mathbf{W m a x}$} \\
\hline & $\mathrm{P} / 2$ & $\mathrm{P} / 3$ & $\mathrm{P} / 4$ & M/1 & $M / 2$ & $M / 3$ \\
\hline \multicolumn{7}{|l|}{ Propalaeotherium sudrei } \\
\hline $\mathrm{N}$ & 2 & 4 & 10 & 6 & 11 & 14 \\
\hline mean & 27.3 & 41.1 & 56.7 & 74.7 & 93.6 & 132.9 \\
\hline \multirow{2}{*}{$\begin{array}{l}\text { standard deviation } \\
\text { coeff. of variation }\end{array}$} & 0.990 & 2.876 & 5.902 & 5.402 & 7.955 & 14.560 \\
\hline & 3.6 & 7.0 & 10.4 & 7.2 & 8.5 & 11.0 \\
\hline AUM 44 & - & - & - & - & 89.1 & - \\
\hline AUM 45 & - & - & - & 71.8 & - & - \\
\hline AUM 71 & 28.0 & 45.1 & - & - & - & - \\
\hline AUM 113 & - & - & - & - & - & 128.0 \\
\hline AUM 163 & - & - & - & - & 74.7 & 111.7 \\
\hline AUM 165 & - & - & - & - & 91.2 & - \\
\hline AUM 166 & - & 40.5 & 56.3 & 71.5 & - & - \\
\hline AUM 171 & - & 40.7 & 55.0 & - & - & - \\
\hline AUM 179 & - & - & 51.0 & 67.9 & 89.3 & 133.6 \\
\hline AUM 182 & - & - & - & 78.8 & - & - \\
\hline AUM 183 & - & - & - & - & 98.6 & 137.8 \\
\hline AUM 205 & - & - & - & - & - & 124.8 \\
\hline AUM 208 & - & - & 58.9 & 82.7 & 98.8 & 141.1 \\
\hline AUM 212 & - & - & - & - & - & 133.5 \\
\hline AUM 215 & - & - & - & - & - & 145.8 \\
\hline AUM 218 & - & - & - & - & - & 145.4 \\
\hline AUM 219 & - & - & - & - & 95.2 & - \\
\hline AUM 220 & - & - & - & - & 97.8 & - \\
\hline AUM 228 & - & - & - & - & - & 133.7 \\
\hline AUM 310 & - & - & 63.7 & - & 104.9 & - \\
\hline AUM 331 & 26.6 & 38.2 & 45.4 & 75.8 & - & - \\
\hline AUM 1572 & - & - & - & - & - & 97.3 \\
\hline AUM 1574 & - & - & 52.8 & - & - & - \\
\hline AUM 1609 & - & - & 61.1 & - & - & - \\
\hline AUM 1610 & - & - & 64.2 & - & - & - \\
\hline AUM 1611 & - & - & 59.2 & - & - & - \\
\hline AUM 1613 & - & - & - & - & - & 147.7 \\
\hline AUM 1614 & - & - & - & - & - & 150.5 \\
\hline AUM 1650 & - & - & - & - & 91.3 & - \\
\hline AUM 1651 & - & - & - & - & 98.8 & - \\
\hline AUM 1655 & - & - & - & - & - & 130.2 \\
\hline AUM 1656 & - & - & - & - & - & 114.7 \\
\hline \multicolumn{7}{|c|}{ Propalaeotherium cf. gaudryi from Aumelas } \\
\hline $\mathrm{N}$ & 1 & 3 & 3 & 5 & 7 & 4 \\
\hline mean & 45.2 & 58.7 & 63.6 & 80.4 & 106.8 & 150.1 \\
\hline standard deviarion & - & 7.360 & 1.022 & 2.396 & 4.760 & 1.335 \\
\hline coeff. of variation & - & 12.5 & 1.6 & 3.0 & 4.5 & 0.9 \\
\hline AUM 206 & - & 50.5 & 63.7 & 84.5 & 106.2 & 151.4 \\
\hline AUM 236 & - & 64.6 & - & - & - & - \\
\hline AUM 1560 & - & 61.0 & - & - & - & - \\
\hline AUM 1561 & 45.2 & - & - & - & - & - \\
\hline AUM 1601 & - & - & - & 79.3 & 110.7 & 150.5 \\
\hline AUM 1603 & - & - & 62.6 & 78.3 & 108.6 & 150.4 \\
\hline AUM 1604 & - & - & - & 80.2 & 100.3 & - \\
\hline AUM 1606 & - & - & 64.6 & 79.5 & 100.3 & 148.2 \\
\hline AUM 1607 & - & - & - & - & 111.3 & - \\
\hline AUM 1608 & - & - & - & - & 110.4 & - \\
\hline \multicolumn{7}{|c|}{ comparing Propalaeotherium cf. gaudryi from Aumelas vs Pr. sudrei } \\
\hline degree of freedom & 1 & 5 & 11 & 9 & 16 & 17 \\
\hline t (cf. gaudryi/sudrei) & 14.7967 & 4.4554 & 1.9490 & 2.1450 & 3.9459 & 2.4334 \\
\hline signification & 95 & 99 & 90 & 90 & 99 & 95 \\
\hline $\begin{array}{l}\text { ratio (cf. gaudryi/ } \\
\text { sudrei) }\end{array}$ & 165.7 & 142.7 & 112.1 & 107.5 & 114.1 & 114.0 \\
\hline
\end{tabular}


APPENDIX 12. - Hypsodonty indices $(\mathbf{I H})$ of upper cheek teeth of the Palaeotheriidae from Aumelas.

\begin{tabular}{|c|c|c|c|c|c|c|c|c|c|}
\hline Taxon & Specimen & Tooth & Wear & $\mathrm{H}_{\mathrm{Pa}}$ & $\mathbf{w}$ & IH & mean & SD & $\mathbf{v}$ \\
\hline Propalaeotherium sudrei & $\begin{array}{l}\text { AUM } 173 \\
\text { AUM } 174 \\
\text { AUM } 175 \\
\text { AUM } 201 \\
\text { AUM } 202 \\
\text { AUM } 207 \\
\text { AUM } 221 \\
\text { AUM } 1592\end{array}$ & $\begin{array}{l}\text { M1/ } \\
\text { M1/ } \\
\text { M3/ } \\
\text { M2/ } \\
\text { M2/ } \\
\text { P4/ } \\
\text { M1/ } \\
\text { M2/ }\end{array}$ & $\begin{array}{l}1 \\
0.5 \\
0.5 \\
0 \\
1 \\
0 \\
0 \\
0.5\end{array}$ & $\begin{array}{l}6.3 \\
5.4 \\
5.9 \\
8.2 \\
7.4 \\
5.3 \\
6.8 \\
7.6 \\
\end{array}$ & \begin{tabular}{r|}
12.9 \\
11.1 \\
13.4 \\
14.6 \\
15.7 \\
9.7 \\
12.8 \\
15.2 \\
\end{tabular} & $\begin{array}{l}0.49 \\
0.49 \\
0.44 \\
0.56 \\
0.47 \\
0.55 \\
0.53 \\
0.50 \\
\end{array}$ & $\begin{array}{c}- \\
- \\
- \\
- \\
- \\
- \\
- \\
0.503\end{array}$ & $\begin{array}{c}- \\
- \\
- \\
- \\
- \\
- \\
- \\
0.0406\end{array}$ & $\begin{array}{l}- \\
- \\
- \\
- \\
- \\
- \\
- \\
8.1\end{array}$ \\
\hline Propalaeotherium cf. gaudryi & $\begin{array}{l}\text { AUM } 168 \\
\text { AUM } 209 \\
\text { AUM } 1583 \\
\text { AUM } 1584 \\
\text { AUM } 1590\end{array}$ & $\begin{array}{l}\text { M3/ } \\
\text { M3/ } \\
\text { M3/ } \\
\text { M3/ } \\
\text { M3/ }\end{array}$ & $\begin{array}{l}0 \\
0 \\
1.5 \\
1 \\
1.5\end{array}$ & $\begin{array}{l}6.5 \\
6.7 \\
5.7 \\
6.0 \\
6.1\end{array}$ & $\begin{array}{l}14.5 \\
16.8 \\
16.0 \\
14.9 \\
17.9\end{array}$ & $\begin{array}{l}\mathbf{0 . 4 5} \\
0.40 \\
0.36 \\
0.40 \\
\mathbf{0 . 3 4}\end{array}$ & $\begin{array}{c}- \\
- \\
- \\
- \\
0.389\end{array}$ & $\begin{array}{c}- \\
- \\
- \\
- \\
0.0424\end{array}$ & $\begin{array}{c}- \\
- \\
- \\
- \\
10.9\end{array}$ \\
\hline Pachynolophus ruscassierensis n. sp. & $\begin{array}{l}\text { AUM } 176 \\
\text { AUM } 187 \\
\text { AUM } 189 \\
\text { AUM } 191 \\
\text { AUM } 194 \\
\text { AUM } 216 \\
\text { AUM } 224 \\
\text { AUM } 231 \\
\text { AUM } 304 \\
\text { AUM } 321 \\
\text { AUM } 324 \\
\text { AUM } 1544 \\
\text { AUM } 1563 \\
\text { AUM } 1564\end{array}$ & $\begin{array}{l}\text { M1/ } \\
\text { M1/ } \\
\text { M2/ } \\
\text { M3/ } \\
\text { M1/ } \\
\text { M2/ } \\
\text { M3/ } \\
\text { M3/ } \\
\text { M3/ } \\
\text { M1/ } \\
\text { M3/ } \\
\text { M3/ } \\
\text { M3/ } \\
\text { M3/ }\end{array}$ & $\begin{array}{l}0 \\
0.5 \\
0.5 \\
0 \\
0 \\
0.5 \\
0 \\
0 \\
0 \\
0 \\
0 \\
0 \\
0.5 \\
0 \\
\end{array}$ & $\begin{array}{l}4.2 \\
4.2 \\
6.2 \\
6.1 \\
6.4 \\
5.5 \\
6.2 \\
5.0 \\
5.9 \\
5.0 \\
6.0 \\
5.7 \\
5.3 \\
5.8 \\
\end{array}$ & \begin{tabular}{l|l|}
11.2 \\
11.3 \\
14.2 \\
12.3 \\
12.1 \\
13.0 \\
14.3 \\
13.5 \\
14.0 \\
11.7 \\
12.4 \\
13.2 \\
12.6 \\
12.2 \\
\end{tabular} & $\begin{array}{l}0.38 \\
0.37 \\
0.44 \\
0.50 \\
0.53 \\
0.42 \\
0.43 \\
0.37 \\
0.42 \\
0.43 \\
0.48 \\
0.43 \\
0.42 \\
0.48 \\
\end{array}$ & $\begin{array}{l}- \\
- \\
- \\
- \\
- \\
- \\
- \\
- \\
- \\
- \\
- \\
- \\
- \\
0.435\end{array}$ & $\begin{array}{l}- \\
- \\
- \\
- \\
- \\
- \\
- \\
- \\
- \\
- \\
- \\
- \\
- \\
0.0472\end{array}$ & $\begin{array}{l}- \\
- \\
- \\
- \\
- \\
- \\
- \\
- \\
- \\
- \\
- \\
- \\
- \\
10.8\end{array}$ \\
\hline Pachynolophus sp. & AUM 213 & M3/ & 0.5 & 6.8 & 16.8 & 0.40 & - & - & - \\
\hline Lophiotherium sp. & AUM 234 & M1/ & 0 & 3.1 & 7.6 & 0.41 & - & - & - \\
\hline
\end{tabular}


APPENDIX 13. - Hypsodonty indices $(\mathrm{IH})$ of upper cheek teeth in some Eocene Palaeotheriidae for comparisons with those of Aumelas. Bold, variation ranges.

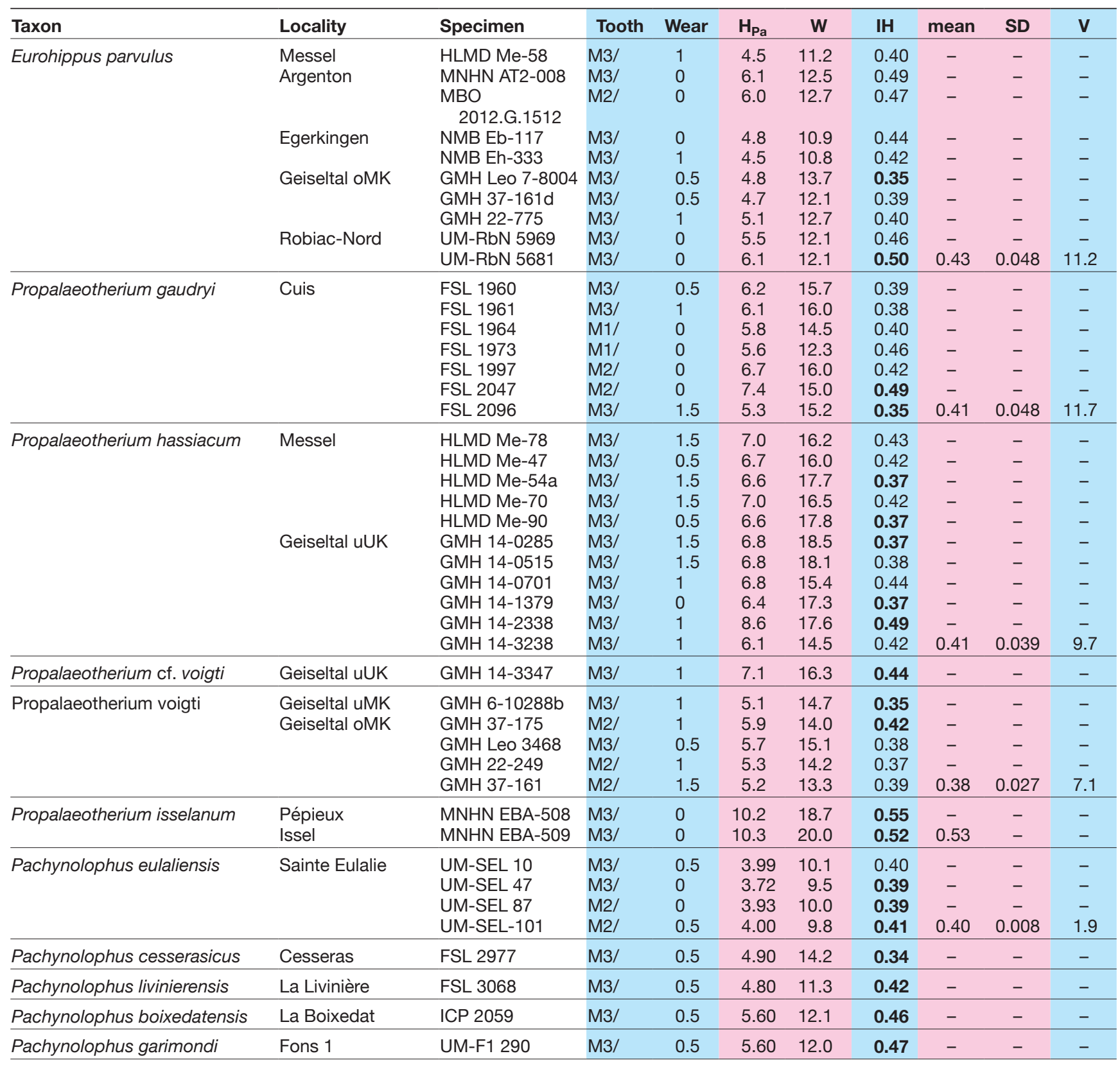

APPENDIX 14. - Comparisons between hypsodonty indices of upper cheek teeth in various Palaeotheriidae. Data from Appendices 12 and 13. Significance probabilities established from Student's t-test.

\begin{tabular}{|c|c|c|c|c|c|c|c|}
\hline & $\begin{array}{c}\text { Pr. sudrei } \\
\text { vs } \\
\text { Eu. parvulus }\end{array}$ & $\begin{array}{c}\text { Pr. sudrei } \\
\text { vs } \\
\text { Pr. gaudryi }\end{array}$ & $\begin{array}{c}\text { Pr. sudrei } \\
\text { vs } \\
\text { Pr. voigti }\end{array}$ & $\begin{array}{c}\text { Pr. sudrei } \\
\text { vs } \\
\text { Pr. hassiacum }\end{array}$ & $\begin{array}{c}\text { Pr. cf. gaudryi } \\
\text { vs } \\
\text { Pr. sudrei }\end{array}$ & $\begin{array}{c}\text { Pr. cf. gaudryi } \\
\text { vs } \\
\text { Pr. gaudryi }\end{array}$ & $\begin{array}{c}\text { Pa. ruscassierensis } \\
\text { n. sp. vs } \\
\text { Pa. eulaliensis }\end{array}$ \\
\hline $\begin{array}{l}\text { degree of freedom } \\
t \\
\text { signification }\end{array}$ & $\begin{array}{l}16 \\
3.3332 \\
99\end{array}$ & $\begin{array}{l}13 \\
3.9313 \\
99\end{array}$ & $\begin{array}{l}11 \\
5.8539 \\
99.9\end{array}$ & $\begin{array}{l}17 \\
5.1635 \\
99.9\end{array}$ & $\begin{array}{l}11 \\
-4.8385 \\
-99.9\end{array}$ & $\begin{array}{l}10 \\
-0.8851 \\
\text { NS }\end{array}$ & $\begin{array}{l}16 \\
1.5901 \\
\text { NS }\end{array}$ \\
\hline ratio & 116.5 & 121.8 & 131.7 & 123.5 & 77.4 & 94.2 & 109.7 \\
\hline
\end{tabular}


APPENDIX 15. - Hypsodonty indices IH' of lower molars of Propalaeotherium sudrei Remy, Krasovec \& Marandat, 2016 and comparison with Pr. gaudryi. Bold, variation ranges. Significance probabilities established from Student's t-test.

Propalaeotherium sudrei from Aumelas

\begin{tabular}{lccccc}
\hline & Tooth & $\mathbf{U}$ & $\mathbf{H}_{\text {Prd }}$ & $\mathbf{W}_{\max }$ & IH' $^{\prime}$ \\
\hline $\mathrm{N}$ & - & - & - & - & 7 \\
mean & - & - & - & - & $\mathbf{8 2 . 3}$ \\
standard deviation & - & - & - & - & 4.318 \\
coeff. of variation & - & - & - & - & 5.2 \\
\hline AUM 179 & $\mathrm{M} / 3$ & 0.5 & 7.0 & 8.0 & $\mathbf{8 7 . 5}$ \\
AUM 208 & $\mathrm{M} / 3$ & 0.5 & 6.7 & 8.5 & 78.8 \\
AUM 1613 & $\mathrm{M} / 3$ & 0 & 6.7 & 8.9 & 75.3 \\
AUM 1614 & $\mathrm{M} / 3$ & 0 & 7.4 & 8.5 & 87.1 \\
AUM 1650 & $\mathrm{M} / 2$ & 0 & 6.4 & 7.8 & 82.1 \\
AUM 1651 & $\mathrm{M} / 2$ & 0 & 6.9 & 8.3 & 83.1 \\
AUM 1656 & $\mathrm{M} / 3$ & 0.5 & 6.4 & 7.8 & 82.1 \\
\hline
\end{tabular}

Propalaeotherium gaudryi from the ageian fauna

\begin{tabular}{lccccc}
\hline & Tooth & $\mathbf{U}$ & $\mathbf{H}_{\text {Prd }}$ & $\mathbf{W}_{\max }$ & $\mathbf{I H}^{\prime}$ \\
\hline $\mathrm{N}$ & - & - & - & - & 8 \\
mean & - & - & - & - & $\mathbf{7 6 . 4}$ \\
standard deviation & - & - & - & - & 3.729 \\
coeff. of variation & - & - & - & - & 4.9 \\
\hline FSL 1967 & $\mathrm{M} / 2$ & 0.5 & 5.9 & 7.4 & 79.7 \\
FSL 2042 & $\mathrm{M} / 3$ & 0.5 & 6.3 & 8.3 & 76.2 \\
MNHN AL-5210 & $\mathrm{M} / 3$ & 0 & 5.9 & 7.4 & 79.7 \\
MNHN L10MA & $\mathrm{M} / 3$ & 0 & 7.2 & 9.6 & 75.4 \\
NMB TS-373 & $\mathrm{M} / 3$ & 0.5 & 6.6 & 8.9 & 74.5 \\
NMB TS-628 & $\mathrm{M} / 3$ & 0.5 & 6.4 & 9.3 & $\mathbf{6 8 . 8}$ \\
NMB TS-82 & $\mathrm{M} / 1$ & 0 & 6.8 & 8.5 & $\mathbf{8 0 . 0}$ \\
UCMP 64904 & $\mathrm{M} / 3$ & 0 & 7.8 & 10.2 & 76.5 \\
\hline
\end{tabular}

\section{Comparing Propalaeotherium sudrei vs Pr. gaudryi}

\begin{tabular}{lccccc}
\hline & Tooth & $\mathbf{U}$ & $\mathbf{H}_{\text {Prd }}$ & $\mathbf{W}_{\max }$ & $\mathbf{I H}^{\prime}$ \\
\hline degree of freedom & - & - & - & - & 13 \\
t (sudrei/gaudryi) & - & - & - & - & 2.8515 \\
signification & - & - & - & - & 98 \\
\hline ratio (sudrei/gaudryi) & - & - & - & - & 107.8 \\
\hline
\end{tabular}

APPENDIX 16. - Upper cheek teeth measures of Propalaeotherium gaudryi (in mm) compared with those of Pr. sudrei Remy, Krasovec \& Marandat, 2016 and Pr. cf. gaudryi from Aumelas. (1), "ageian fauna"; Bold, variation ranges. Significance probabilities established from Student's t-test.

\begin{tabular}{|c|c|c|c|c|c|c|c|c|c|c|c|c|c|c|c|c|c|c|}
\hline & \multicolumn{2}{|c|}{ P2/ } & \multicolumn{2}{|c|}{ P3/ } & \multicolumn{2}{|c|}{ P4/ } & \multicolumn{4}{|c|}{ M1/ } & \multicolumn{4}{|c|}{ M2/ } & \multicolumn{4}{|c|}{ M3/ } \\
\hline & $\mathbf{L}$ & $\mathbf{W}$ & $\mathbf{L}$ & W & $\mathbf{L}$ & $\mathbf{W}$ & $\mathbf{L}$ & W & D & d & $\mathbf{L}$ & W & D & d & $\mathbf{L}$ & W & D & d \\
\hline \multicolumn{19}{|c|}{ Propalaeotherium gaudryi } \\
\hline $\mathrm{N}$ & 5 & 5 & 10 & 10 & 10 & 10 & 18 & 19 & 18 & 18 & 20 & 20 & 20 & 20 & 21 & 21 & 21 & 21 \\
\hline mean & 7.2 & 7.5 & 8.1 & 9.7 & 9.0 & 11.5 & 11.4 & 13.8 & 14.5 & 13.4 & 12.9 & 15.4 & 16.4 & 14.6 & 13.3 & 15.5 & 16.7 & 15.0 \\
\hline standard deviation & 0.328 & 0.981 & 0.271 & 0.689 & 0.881 & 1.062 & 0.838 & 0.953 & 0.929 & 0.895 & 0.771 & 0.980 & 0.989 & 1.002 & 1.067 & 0.734 & 1.075 & 0.864 \\
\hline coeff. of variation & 4.5 & 13.1 & 3.4 & 7.1 & 9.8 & 9.2 & 7.3 & 6.9 & 6.4 & 6.7 & 6.0 & 6.4 & 6.0 & 6.8 & 8.0 & 4.7 & 6.4 & 5.8 \\
\hline \multicolumn{19}{|l|}{ Mancy } \\
\hline MNHN L41Ma & - & - & - & - & - & - & - & - & - & - & - & - & - & - & 14.1 & 15.3 & 16.9 & 14.9 \\
\hline MNHN MA-14788 & - & - & - & - & - & - & - & - & - & - & 13.0 & 15.6 & 17.1 & 14.8 & 13.6 & 16.3 & 17.1 & 15.4 \\
\hline MNHN MA-14795 & - & - & - & - & - & - & - & - & - & - & 13.3 & 17.1 & 17.7 & 15.2 & 16.7 & 16.9 & 19.8 & 16.4 \\
\hline MNHN MA-14802 & - & - & - & - & - & - & - & - & - & - & 12.4 & 15.4 & 15.9 & 14.4 & 13.1 & 16.4 & 16.7 & 14.4 \\
\hline MNHN MA-14842 & 7.1 & 6.4 & - & - & - & - & - & - & - & - & - & - & - & - & - & - & - & - \\
\hline MNHN MA-14885 & - & - & - & - & - & - & 11.1 & 13.0 & - & 12.9 & 13.1 & 15.4 & 17.3 & 15.4 & 13.8 & 16.4 & 17.8 & 16.4 \\
\hline MNHN MA-14948 & 7.6 & 8.8 & 8.0 & 10.0 & 9.2 & 11.4 & 10.7 & 13.2 & 14.0 & 12.5 & 12.1 & 15.0 & 16.1 & 14.9 & 13.2 & 15.7 & 17.0 & 15.1 \\
\hline MNHN MCY-4 & - & - & - & - & - & - & - & - & - & - & 11.8 & 13.6 & 14.1 & 12.7 & 14.2 & 15.8 & 16.7 & 16.3 \\
\hline MNHN MCY-5 & - & - & - & - & - & - & - & - & - & - & 12.4 & 14.5 & 15.8 & 13.7 & 13.3 & 15.2 & 16.2 & 14.7 \\
\hline MNHN MCY-6 & - & - & - & - & - & - & - & - & - & - & 12.6 & 14.7 & 16.4 & 14.1 & 12.7 & 15.2 & 16.0 & 15.1 \\
\hline MNHN MCY-7 & - & - & - & - & 9.0 & 12.7 & - & - & - & - & - & - & - & - & - & - & - & - \\
\hline MNHN MCY-8 & - & - & - & - & - & - & - & - & - & - & 13.1 & 15.0 & 16.0 & 14.1 & - & - & - & - \\
\hline \multicolumn{19}{|l|}{ Monthelon } \\
\hline FSL 2047 & - & - & - & - & - & - & - & - & - & - & 12.8 & 15.0 & 16.2 & 14.1 & - & - & - & - \\
\hline FSL 2048 & - & - & - & - & 10.3 & 12.4 & - & - & - & - & - & - & - & - & - & - & - & - \\
\hline
\end{tabular}




\begin{tabular}{|c|c|c|c|c|c|c|c|c|c|c|c|c|c|c|c|c|c|c|}
\hline & \multicolumn{2}{|c|}{ P2/ } & \multicolumn{2}{|c|}{ P3/ } & \multicolumn{2}{|c|}{ P4/ } & \multicolumn{4}{|c|}{ M1/ } & \multicolumn{4}{|c|}{ M2/ } & \multicolumn{4}{|c|}{ M3/ } \\
\hline & $\mathbf{L}$ & w & $\mathbf{L}$ & w & $\mathbf{L}$ & w & $\mathbf{L}$ & w & D & d & $\mathbf{L}$ & w & D & d & $\mathbf{L}$ & w & D & d \\
\hline \multicolumn{19}{|l|}{ Grauves } \\
\hline MNHN GR-7573 & - & - & - & - & 7.9 & 9.9 & - & - & - & - & - & - & - & - & - & - & - & - \\
\hline MNHN GR-7576 & - & - & - & - & 9.2 & 11.2 & - & - & - & - & - & - & - & - & - & - & - & - \\
\hline MNHN L13GR & - & - & 8.0 & 10.2 & - & - & - & - & - & - & - & - & - & - & - & - & - & - \\
\hline MNHN L31GR & - & - & - & - & 9.7 & 12.5 & - & - & - & - & - & - & - & - & - & - & - & - \\
\hline MNHN L33GR & - & - & 8.0 & 8.8 & - & - & - & - & - & - & - & - & - & - & - & - & - & - \\
\hline MNHN L35GR & - & - & - & - & 9.4 & 11.0 & - & - & - & - & _- & - & - & _- & - & - & - & - \\
\hline MNHN L42GR & - & _- & _- & _- & - & - & 11.2 & 14.1 & 14.4 & 13.4 & _- & - & _ & _- & _- & - & _- & - \\
\hline MNHN L46GR & - & - & - & - & - & - & 10.8 & 12.5 & 13.4 & 12.3 & - & - & - & - & - & - & - & - \\
\hline MNHN L54GR & - & - & - & - & - & - & - & - & - & - & - & - & - & - & 12.5 & 14.3 & 15.5 & 14.4 \\
\hline MNHN L60GR & - & - & - & - & - & - & 11.6 & 13.6 & 14.0 & 13.4 & - & - & - & - & - & - & - & - \\
\hline MNHN L61GR & - & - & - & - & - & - & - & - & - & - & 11.7 & 15.4 & 16.0 & 14.0 & 11.6 & 14.6 & 14.8 & 12.9 \\
\hline MNHN L62GR & - & - & - & - & - & - & - & - & - & - & 12.3 & 14.0 & 15.4 & 14.2 & 13.8 & 14.8 & 17.0 & 15.4 \\
\hline Cuis (1) & - & - & - & - & - & - & - & - & - & - & - & - & - & - & - & - & - & - \\
\hline FSL 1960 & - & - & _- & _- & _- & _- & 12.1 & 14.0 & 14.8 & 14.0 & 13.6 & 15.8 & 16.9 & 15.0 & 13.6 & 15.8 & 17.2 & 15.3 \\
\hline FSL 1961 & - & _- & _- & _- & _- & _- & 12.0 & 14.5 & 15.6 & 13.6 & 14.2 & 16.8 & 17.4 & 15.6 & 14.2 & 16.0 & 17.0 & 14.4 \\
\hline FSL 1963 & - & - & - & - & - & - & - & - & - & - & 13.5 & 14.9 & 16.6 & 14.5 & - & - & - & - \\
\hline FSL & - & - & - & - & - & - & 11.9 & 14.5 & 14.7 & 13.5 & - & - & - & - & - & - & - & - \\
\hline FSL 1965 & - & _- & _- & _- & _- & - & - & 14.4 & 14.4 & - & _- & - & _- & _- & - & - & _- & - \\
\hline FSL 1973 & - & - & - & - & - & - & 11.5 & 12.3 & 13.7 & 12.9 & - & - & - & - & - & - & - & - \\
\hline $\mathrm{FS}$ & - & - & - & - & - & - & - & - & - & - & 13.5 & 16.0 & 17.4 & 14.6 & - & - & - & - \\
\hline FSL 1999 & - & - & - & - & - & _- & 11.0 & 13.2 & 14.2 & 13.1 & - & - & - & - & - & - & - & - \\
\hline FSL 2000 & - & - & 8.3 & 10.5 & - & - & - & - & - & - & - & - & - & - & - & - & - & _- \\
\hline FSL 2096 & 6.8 & 6.7 & 8.2 & 10.2 & 8.1 & 11.8 & 10.9 & 13.2 & 14.1 & 12.7 & 12.6 & 15.5 & 16.0 & 14.4 & 12.8 & 15.3 & 16.6 & 14.2 \\
\hline MNHN AL 6532 & - & - & - & - & - & - & - & - & - & - & - & - & - & - & 13.2 & 15.5 & 16.6 & 15.3 \\
\hline MNHN AL 6533 & - & - & - & - & - & _- & - & - & - & - & 14.7 & 17.2 & 18.4 & 17.0 & - & - & - & - \\
\hline MNHN AL 6534 & - & - & - & - & - & - & 12.5 & 15.1 & 15.5 & 14.5 & - & - & - & - & - & - & - & - \\
\hline MNHN AL 6535 & _- & _- & _- & _- & _- & _- & 12.1 & 14.1 & 15.1 & 14.3 & _- & - & _- & - & - & - & _- & - \\
\hline MNHN AL 6536 & _- & _- & _- & _ & _- & - & 12.9 & 15.7 & 16.6 & 14.7 & _- & _- & _- & _- & _- & _- & _- & _- \\
\hline MNHN AL 6537 & 7.5 & 8.1 & - & - & - & - & - & - & - & - & - & - & - & - & - & - & - & - \\
\hline MNHN AL 6538 & - & - & 8.5 & 10.2 & - & - & - & - & _- & - & _- & - & - & _- & - & - & - & - \\
\hline MNHN A & - & - & 7.9 & 9.4 & - & - & - & - & - & - & - & - & - & - & - & - & - & - \\
\hline MNHN AT2-007 & - & - & - & - & - & - & - & - & - & - & - & - & - & - & 14.0 & 16.0 & 17.7 & 15.2 \\
\hline MNHN AT2-013A & - & - & 7.7 & 9.2 & - & - & - & - & - & - & - & - & - & - & - & - & - & - \\
\hline MNHN AT2-019 & _- & - & - & - & _- & _- & 9.8 & 13.0 & 13.8 & 12.4 & _- & - & _- & _- & - & - & - & _- \\
\hline MNHN AT2-019 & - & - & - & - & - & - & - & - & - & - & - & - & - & - & 12.2 & 14.8 & 15.6 & 14.6 \\
\hline MNHN AT2-019 & - & - & - & - & - & - & 9.9 & 12.7 & 12.8 & 11.9 & 12.2 & 14.0 & 15.0 & 13.5 & 12.1 & 14.3 & 14.9 & 14.0 \\
\hline MNHN AT2-020A & _- & _- & _- & _- & _- & _- & 11.7 & 15.0 & 15.7 & 14.5 & - & - & - & - & - & - & - & - \\
\hline MNHN AT2-020B & _- & _- & _- & _- & _- & _- & - & - & - & - & _- & - & _- & _- & 12.5 & 14.8 & 16.1 & 14.3 \\
\hline MNHN AT2-021 & - & - & 7.9 & 8.6 & 7.6 & 9.9 & - & - & - & - & - & - & - & - & - & - & - & - \\
\hline NMB TS-83 & 7.2 & 7.5 & 8.5 & 10.4 & 9.9 & 12.7 & 12.0 & 14.4 & 14.7 & 14.7 & 13.3 & 16.2 & 16.8 & 16.7 & 12.8 & 16.1 & 17.1 & 16.1 \\
\hline
\end{tabular}

\section{Comparing Propalaeotherium sudrei from Aumelas vs Pr. gaudryi}

$\begin{array}{lllllllllllllllllll}\text { degree of freedom } & 4 & 4 & 10 & 10 & 13 & 13 & 22 & 23 & 22 & 22 & 22 & 22 & 22 & 22 & 22 & 21 & 22 & 22\end{array}$ $\mathrm{t}$ (sudrei/gaudryi) $\quad-0.3622-1.4981-0.1534-1.3156-1.0147-0.9896-2.5659-3.7245-2.8510-2.4155-2.4988-2.6473-2.7691-1.3443-2.1425-3.3824-2.6449-1.9302$ $\begin{array}{lllllllllllllllllllll}\text { signification } & N S & N S & N S & N S & N S & N S & -98 & -99 & -99 & -95 & -95 & -98 & -98 & \text { NS } & -95 & -99 & -98 & -90\end{array}$

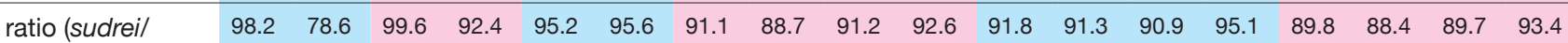
gaudryi)

\section{Comparing Propalaeotherium cf. gaudryi from Aumelas vs Pr. gaudryi}

$\begin{array}{lllllllllllllllllll}\text { degree of freedom } & 6 & 6 & 11 & 11 & 14 & 14 & 20 & 21 & 20 & 21 & 25 & 24 & 25 & 25 & 30 & 30 & 30 & 29\end{array}$

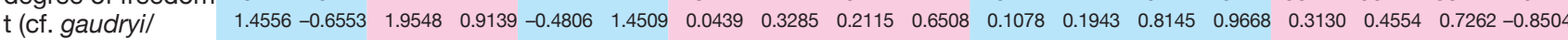
gaudryi)

$\begin{array}{llllllllllllllllllllllllllllll}\text { signification } & N S & N S & 90 & N S & N S & N S & N S & N S & N S & N S & N S & \text { NS } & \text { NS } & \text { NS } & \text { NS } & \text { NS } & \text { NS } & \text { NS }\end{array}$

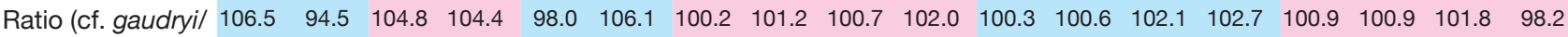
gaudryi)

\section{Comparing Propalaeotherium cf. gaudryi from Aumelas vs Pr. sudrei}

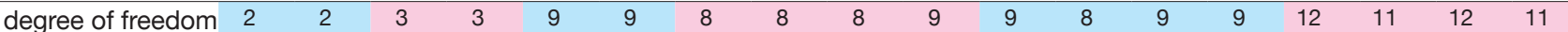

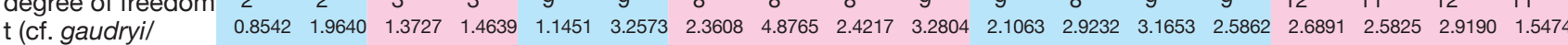
sudrei)

$\begin{array}{llllllllllllllllllll}\text { signification } & N S & N S & N S & N S & \text { NS } & \mathbf{9 9} & \mathbf{9 5} & \mathbf{9 9} & \mathbf{9 5} & \mathbf{9 9} & \mathbf{9 0} & \mathbf{9 8} & \mathbf{9 8} & \mathbf{9 5} & \mathbf{9 8} & \mathbf{9 5} & \mathbf{9 8} & \text { NS }\end{array}$

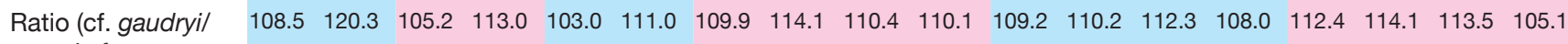
sudrei) 
APPENDIX 17. - Lower cheek teeth measures of Propalaeotherium gaudryi (in mm) compared with those of Pr. sudrei Remy, Krasovec \& Marandat, 2016 and Pr. cf. gaudryi from Aumelas. (1), "ageian fauna"; Bold, variation ranges. Significance probabilities established from Student's t-test.

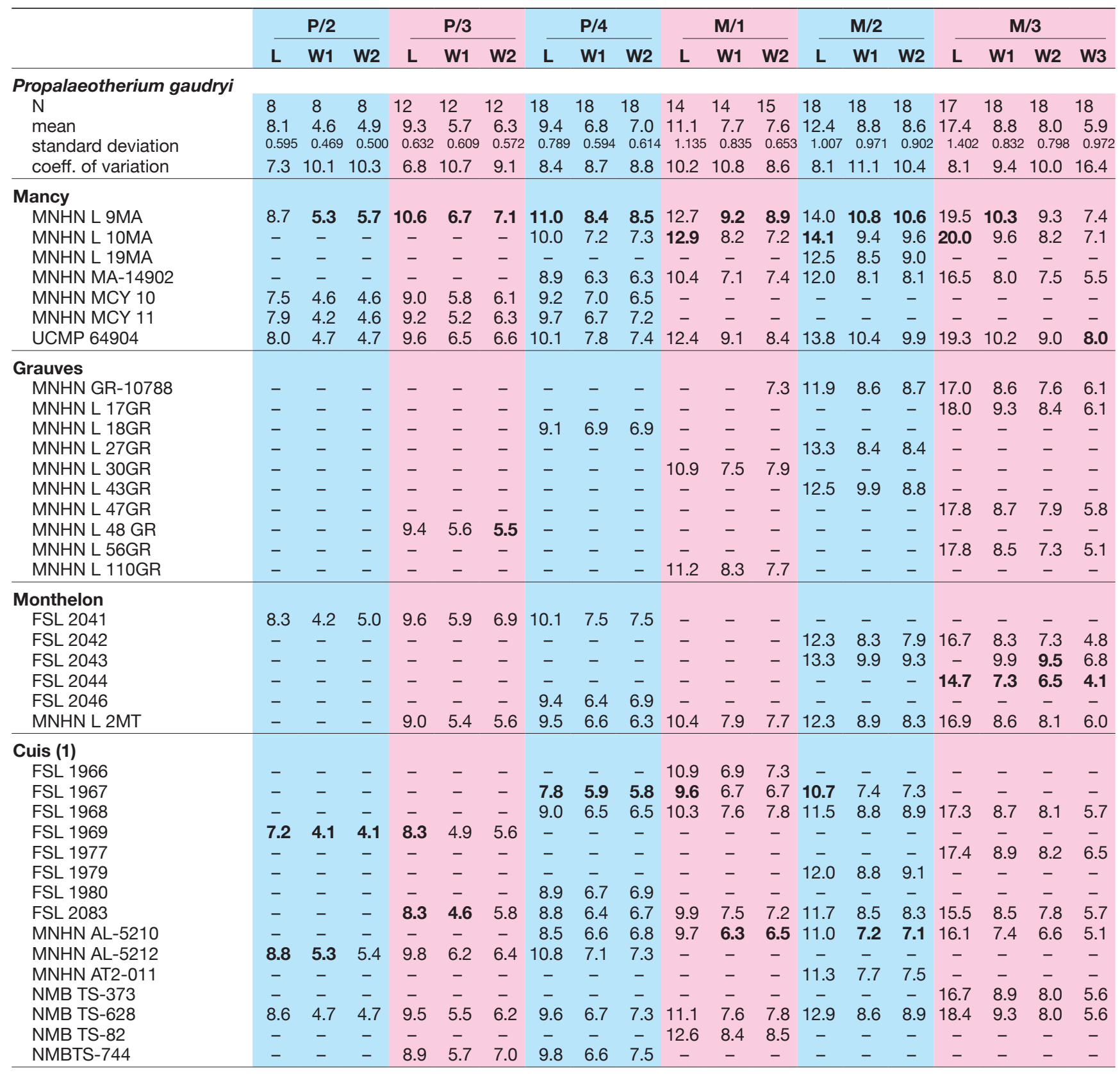

Comparing Propalaeotherium sudrei from Aumelas vs Pr. gaudryi

\begin{tabular}{lcccccccccccccccccccccccccc} 
degree of freedom & 8 & 9 & 9 & 14 & 14 & 14 & 26 & 26 & 26 & 18 & 18 & 19 & 27 & 27 & 27 & 31 & 35 & 35 & 32 \\
$\mathrm{t}($ sudrei/gaudryi) & -2.5649 & -3.1925 & -3.4038 & -4.1276 & -3.2199 & -3.3801 & -1.7647 & -3.2820 & -3.2531 & -2.0834 & -1.0001 & -1.3136 & -2.7240 & -2.1735 & -2.6362 & -3.1395 & -2.4298 & -2.5396 & -1.2845 \\
signification & -95 & -98 & -99 & -99 & -99 & -99 & -90 & -99 & -99 & -90 & NS & NS & -98 & -95 & -98 & -99 & -95 & -98 & NS \\
\hline Ratio (sudrei/gaudryi) & 86.1 & 80.6 & 78.8 & 85.0 & 81.4 & 83.5 & 94.8 & 89.9 & 89.7 & 90.9 & 95.4 & 95.1 & 92.6 & 92.2 & 91.3 & 92.4 & 93.7 & 92.8 & 94.4 \\
\hline
\end{tabular}

\section{Comparing Propalaeotherium cf. gaudryi from Aumelas vs Pr. gaudryi}

$\begin{array}{lllllllllllllllllllllll}\text { degree of freedom } & 7 & 7 & 7 & 13 & 13 & 14 & 19 & 19 & 20 & 17 & 17 & 19 & 23 & 23 & 23 & 19 & 20 & 20 & 20\end{array}$ $\begin{array}{llllllllllllllllllllllll}t \text { (cf. gaudryi/gaudryi) } & 0.9034 & -0.2599 & 0.6379 & 0.0755 & -0.4506 & 0.0626 & -0.3868 & -1.7238 & -0.1592 & -0.7319 & -1.4390 & -0.2483 & -0.4897 & -0.1839 & -0.8749 & 0.3942 & -0.7635 & -0.9428 & -0.7819\end{array}$ signification

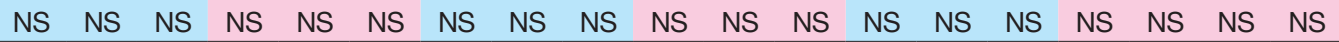

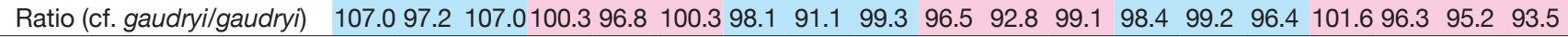

\section{Comparing Propalaeotherium cf. gaudryi from Aumelas vs Pr. sudrei}

\begin{tabular}{lllllllllllllllllllllllll} 
degree of freedom & 1 & 2 & 2 & 5 & 5 & 6 & 11 & 11 & 12 & 9 & 9 & 10 & 16 & 16 & 16 & 18 & 21 & 21 & 18 \\
t (cf. gaudryi/sudrei) & - & 11.5000 & 7.7483 & 3.4918 & 2.2577 & 4.2426 & 1.0299 & 0.3415 & 2.9592 & 2.2037 & -1.1704 & 1.3838 & 2.9310 & 2.7608 & 2.3858 & 3.2250 & 0.8145 & 0.6611 & -0.2905 \\
signification & - & 99 & 98 & 98 & 90 & 99 & NS & NS & 98 & 90 & NS & NS & 99 & 98 & 95 & 99 & NS & NS & NS \\
\hline Ratio (cf. gaudryi/sudrei) & 124.3 & 120.5 & 135.7 & 118.1 & 118.9 & 120.1 & 103.4 & 101.4 & 110.6 & 106.1 & 97.2 & 104.1 & 106.3 & 107.6 & 105.5 & 110.0 & 102.7 & 102.5 & 99.0
\end{tabular}

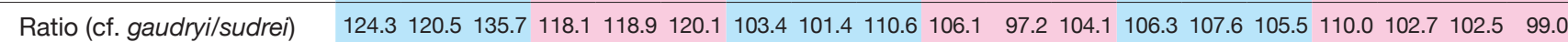


APPENDIX 18. - Upper cheek teeth measures (in mm) of Propalaeotherium voigti and Pr. cf. voigti compared to those of Pr. sudrei Remy, Krasovec \& Marandat, 2016 and Pr. cf. gaudryi from Aumelas. Bold, variation ranges. Significance probabilities established from Student's t-test. The holotype of Pr. voigti (GMH $37-$ 135 ) is difficult to measure.

\begin{tabular}{|c|c|c|c|c|c|c|c|c|c|c|c|c|c|c|c|c|c|c|c|}
\hline & & \multicolumn{2}{|c|}{ P2/ } & \multicolumn{2}{|c|}{ P3/ } & \multicolumn{2}{|c|}{ P4/ } & \multicolumn{4}{|c|}{ M1/ } & \multicolumn{4}{|c|}{ M2/ } & \multicolumn{4}{|c|}{ M3/ } \\
\hline & & $\mathbf{L}$ & $\mathbf{W}$ & $\mathbf{L}$ & $\mathbf{W}$ & $\mathbf{L}$ & $\mathbf{W}$ & $\mathbf{L}$ & $\mathbf{W}$ & D & d & $\mathbf{L}$ & W & D & d & $\mathbf{L}$ & W & D & d \\
\hline \multicolumn{20}{|c|}{ Data Propalaeotherium voigti (Geiseltal mUK to oMK) } \\
\hline \multirow{4}{*}{\multicolumn{2}{|c|}{$\begin{array}{l}\mathrm{N} \\
\text { mean } \\
\text { standard deviation } \\
\text { coeff. of variation }\end{array}$}} & 2 & 2 & 3 & 3 & 6 & 6 & 5 & 5 & 5 & 5 & 8 & 8 & 8 & 8 & 8 & 8 & 8 & 8 \\
\hline & & 7.2 & 6.8 & 7.7 & 9.4 & 8.4 & 11.2 & 10.4 & 12.7 & 13.6 & 12.3 & 11.6 & 14.0 & 15.1 & 13.7 & 12.0 & 14.3 & 15.7 & 14.0 \\
\hline & & 0.566 & 0.212 & 0.252 & 0.808 & 0.592 & 0.157 & 0.536 & 0.505 & 0.604 & 0.541 & 0.455 & 0.424 & 0.681 & 0.503 & 0.472 & 0.429 & 0.452 & 0.537 \\
\hline & & 7.9 & 3.1 & 3.3 & 8.6 & 7.1 & 1.4 & 5.1 & 4.0 & 4.4 & 4.4 & 3.9 & 3.0 & 4.5 & 3.7 & 3.9 & 3.0 & 2.9 & 3.8 \\
\hline mUK & GMH 09-708 & - & - & - & - & - & - & - & - & - & - & 11.7 & 13.6 & 14.3 & 13.3 & 11.8 & 13.8 & 15.4 & 13.4 \\
\hline \multirow[t]{2}{*}{ uMK } & $\begin{array}{l}\text { GMH } \\
\quad 06-10288 a\end{array}$ & 7.6 & 6.6 & 8.0 & 8.7 & 9.0 & 11.3 & 10.7 & 13.5 & 14.6 & 13.0 & 12.3 & 14.7 & 16.3 & 14.8 & 12.9 & 14.7 & 16.6 & 14.3 \\
\hline & GMH 06-795 & - & - & - & - & 8.3 & 11.3 & 10.7 & 12.6 & 13.4 & 12.7 & 11.6 & 13.7 & 14.5 & 13.5 & 12.6 & 13.9 & 15.7 & 13.4 \\
\hline \multirow[t]{5}{*}{ oMK } & GMH 22-249 & - & - & - & - & 8.8 & 11.2 & - & - & - & - & 11.8 & 14.2 & 15.5 & 13.3 & 12.0 & 14.3 & 15.6 & 13.6 \\
\hline & GMH 37-161 & - & - & 7.7 & 10.3 & 8.3 & 11.3 & 10.4 & 12.1 & 13.2 & 11.7 & 11.5 & 13.3 & 14.9 & 13.8 & 12.0 & 14.1 & 15.3 & 14.3 \\
\hline & GMH 37-175 & - & - & - & - & 8.5 & 11.1 & 10.8 & 12.7 & 13.7 & 12.4 & 12.0 & 14.0 & 15.7 & 14.0 & 11.8 & 14.3 & 15.5 & 14.4 \\
\hline & GMH 37-176 & 6.8 & 6.9 & 7.5 & 9.3 & 7.3 & 10.9 & 9.5 & 12.6 & 13.1 & 11.9 & 10.9 & 14.1 & 15.1 & 13.6 & 11.6 & 14.1 & 15.3 & 13.6 \\
\hline & $\begin{array}{l}\text { GMH Leo-3- } \\
\quad 3468\end{array}$ & - & - & - & - & - & - & - & - & - & - & 11.1 & 14.0 & 14.6 & 13.4 & 11.6 & 15.1 & 16.1 & 14.8 \\
\hline
\end{tabular}

Data Propalaeotherium cf. voigti (Geiseltal uUK)

\begin{tabular}{|c|c|c|c|c|c|c|c|c|c|c|c|c|c|c|c|c|c|c|c|}
\hline $\begin{array}{l}\mathrm{N} \\
\text { mean }\end{array}$ & & $\begin{array}{l}2 \\
8.3 \\
\end{array}$ & $\begin{array}{l}2 \\
8.4 \\
\end{array}$ & $\begin{array}{l}2 \\
9.2 \\
\end{array}$ & $\begin{array}{c}2 \\
11.3\end{array}$ & $\begin{array}{l}2 \\
9.9\end{array}$ & $\begin{array}{c}2 \\
13.8 \\
\end{array}$ & $\begin{array}{c}2 \\
11.8 \\
\end{array}$ & $\begin{array}{c}2 \\
14.8 \\
\end{array}$ & $\begin{array}{c}1 \\
15.1 \\
\end{array}$ & $\begin{array}{c}2 \\
14.4 \\
\end{array}$ & $\begin{array}{c}2 \\
13.0\end{array}$ & $\begin{array}{c}2 \\
16.0 \\
\end{array}$ & $\begin{array}{c}2 \\
16.2 \\
\end{array}$ & $\begin{array}{c}2 \\
15.6\end{array}$ & $\begin{array}{c}1 \\
13.0 \\
\end{array}$ & $\begin{array}{c}1 \\
16.3 \\
\end{array}$ & $\begin{array}{c}1 \\
17.1 \\
\end{array}$ & $\begin{array}{c}1 \\
15.3 \\
\end{array}$ \\
\hline uUK & GMH 14-3347 & 8.4 & 7.9 & 9.3 & 10.6 & 10.1 & 14 & 12.1 & 14.7 & - & 14.9 & 13.1 & 16.1 & 16.8 & 16.2 & 13 & 16.3 & 17.1 & 15.3 \\
\hline & GMH 14-3428 & 8.1 & 8.9 & 9.1 & 12 & 9.6 & 13.6 & 11.5 & 14.8 & 15.1 & 13.8 & 12.8 & 15.8 & 15.6 & 15 & - & - & - & - \\
\hline
\end{tabular}

\section{Comparing Propalaeotherium cf. voigti (uUK) vs Pr. voigti (mUK to oMK)}

$\begin{array}{llllllllllllllllllll}\text { degree of freedom } & 2 & 2 & 3 & 3 & 6 & 6 & 5 & 5 & 4 & 5 & 7 & 7 & 7 & 7 & 6 & 6 & 6 & 6\end{array}$ t (cf. voigti/voigti) signification

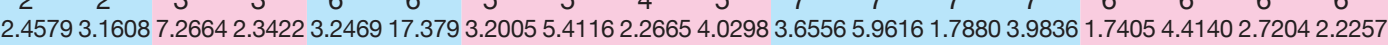

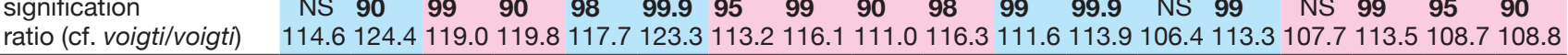

\section{Comparing Propalaeotherium sudrei vs Pr. voigti (mUK to oMK)}

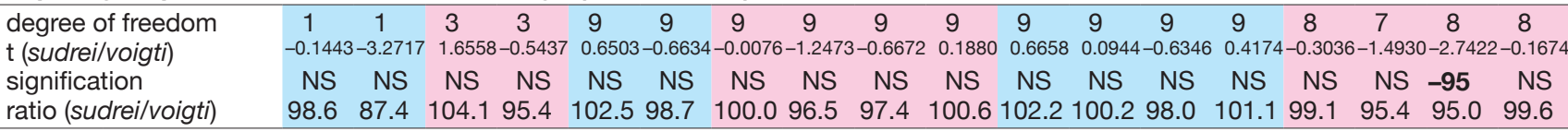

\section{Comparing Propalaeotherium cf. gaudryi from Aumelas vs Pr. voigti (mUK to oMK)}

$\begin{array}{llllllllllllllllllll}\text { degree of freedom } & 3 & 3 & 4 & 4 & 10 & 10 & 7 & 7 & 7 & 8 & 12 & 11 & 12 & 12 & 16 & 16 & 16 & 15 & \\ \text { t (cf. gaudryi/voigti) } & 0.9214 & 0.8538 & 2.6679 & 1.1112 & 1.7780 & 3.7650 & 3.5935 & 4.5023 & 2.6144 & 4.3597 & 3.6083 & 3.7925 & 3.6392 & 3.9650 & 3.6801 & 3.1232 & 2.7872 & 1.9958 \\ \text { signification } & \text { NS } & \text { NS } & 90 & \text { NS } & \text { NS } & 99 & 99 & 99 & 95 & 99 & 99 & 99 & 99 & 99 & 99 & 99 & 98 & 90 & 99 \\ \text { ratio (cf. gaudryi/voigti) } & 106.9 & 105.2 & 109.5 & 107.8 & 105.6 & 109.5 & 109.9 & 110.0 & 107.6 & 110.8 & 111.6 & 110.4 & 110.1 & 109.2 & 111.4 & 108.9 & 107.9 & 104.7\end{array}$

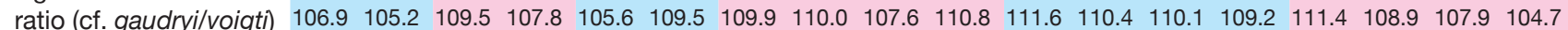


APPENDIX 19. - MMT/MMM ratio in several perissodactyls (see Fig. 6). Abbreviations: MMM, vertical distance from surface of condyle to bottom of angular process of the mandible; MMT, horizontal distance from rear of condyle to anterior side of ascending ramus. The terms "vertical" and "horizontal" refer to occlusal plane of teeth. The data concerning GMH 14-1311 (Propalaeotherium hassiacum) (Remy et al. 2016: supp. data 3B) have been forsaken because the ramus of this specimen is mesio-distally crushed. The selected ages (MY) were established from Escarguel et al. 1997, Franzen 2005, Wade et al. 2011, Gradstein et al. 2012. Specimens of Aumelas and La Livinière 1 are assumed to be intermediate between MP 10 and 12. Leptolophus nouleti is estimated a little older than the Robiac fauna.

\begin{tabular}{|c|c|c|c|c|c|c|c|}
\hline Taxa & & Specimens & MMT & MMM & $\begin{array}{l}\text { MMT/ } \\
\text { MMM }\end{array}$ & Age (MY) & \\
\hline Propalaeotherium & $\begin{array}{l}\text { gaudryi } \\
\text { voigti } \\
\text { sudrei }\end{array}$ & $\begin{array}{l}\text { UCMP } 64904 \\
\text { GMH } 37-135 \\
\text { AUM } 205\end{array}$ & $\begin{array}{l}43.6 \\
27.1 \\
33.8\end{array}$ & $\begin{array}{l}93.2 \\
57.7 \\
68.3\end{array}$ & $\begin{array}{l}46.7 \\
46.9 \\
49.5\end{array}$ & $\begin{array}{l}-50 \\
-44.2 \\
-45.7\end{array}$ & $\begin{array}{l}\text { Savage et al. 1965: fig. } 10 \\
\text { photo from original } \\
\text { original }\end{array}$ \\
\hline Eurohippus & $\begin{array}{l}\text { parvulum } \\
\text { parvulum }\end{array}$ & $\begin{array}{l}\text { HLMD Me-7582 } \\
\text { HLMD Me-7440 }\end{array}$ & $\begin{array}{l}24.4 \\
25.3\end{array}$ & $\begin{array}{l}42.5 \\
38.9\end{array}$ & $\begin{array}{l}57.5 \\
65.1\end{array}$ & $\begin{array}{l}-47.8 \\
-47.8 \\
\end{array}$ & $\begin{array}{l}\text { photo from original } \\
\text { photo from original }\end{array}$ \\
\hline Pachynolophus & $\begin{array}{l}\text { livinierensis } \\
\text { eulaliensis } \\
\text { eulaliensis }\end{array}$ & $\begin{array}{l}\text { NHMB Liv-28 } \\
\text { UM-SEL } 23 \\
\text { UM-SEL } 24\end{array}$ & $\begin{array}{l}28.2 \\
23.5 \\
20.2\end{array}$ & $\begin{array}{l}48.3 \\
35.0 \\
32.9\end{array}$ & $\begin{array}{l}58.5 \\
67.1 \\
61.3\end{array}$ & $\begin{array}{l}-49 \\
-52 \\
-52\end{array}$ & $\begin{array}{l}\text { Savage et al. 1965: fig. } 19 \\
\text { original } \\
\text { original }\end{array}$ \\
\hline Lophiotherium & $\begin{array}{l}\text { pygmaeum } \\
\text { sp. AUM }\end{array}$ & $\begin{array}{l}\text { MNHN DF-918 } \\
\text { AUM } 1548\end{array}$ & $\begin{array}{l}26.5 \\
23.0\end{array}$ & $\begin{array}{l}46.3 \\
48.5\end{array}$ & $\begin{array}{l}57.2 \\
47.4 \\
\end{array}$ & $\begin{array}{l}-42.6 \\
-49 \\
\end{array}$ & $\begin{array}{l}\text { photo from original } \\
\text { original }\end{array}$ \\
\hline Palaeotherium & $\begin{array}{l}\text { muehlbergi thaleri } \\
\text { medium euzetense } \\
\text { duvali duvali }\end{array}$ & $\begin{array}{l}\text { UM-SEO } 2 \\
\text { FSL } 6531 \\
\text { MNHN GY-522 }\end{array}$ & $\begin{array}{l}53.9 \\
60.0 \\
30.5\end{array}$ & $\begin{array}{r}131.4 \\
109.5 \\
65.4 \\
\end{array}$ & $\begin{array}{l}41.0 \\
54.8 \\
46.6\end{array}$ & $\begin{array}{l}-34.9 \\
-37 \\
-34.8\end{array}$ & $\begin{array}{l}\text { photo from original } \\
\text { Depéret 1917: pl. } 1 \\
\text { Remy 1992: fig. } 20\end{array}$ \\
\hline Plagiolophus & $\begin{array}{l}\text { minor } \\
\text { ministri } \\
\text { annectens }\end{array}$ & $\begin{array}{l}\text { MNHN GY-527 } \\
\text { FPO VIL-1973 } 344 \\
\text { FSL } 4999\end{array}$ & $\begin{array}{l}22.9 \\
32.6 \\
28.5\end{array}$ & $\begin{array}{l}51.8 \\
77.4 \\
63.5\end{array}$ & $\begin{array}{l}44.2 \\
42.1 \\
44.9\end{array}$ & $\begin{array}{l}-34.8 \\
-30.2 \\
-37\end{array}$ & $\begin{array}{l}\text { photo from original } \\
\text { Brunet \& Jéhenne 1989: fig. 12B } \\
\text { original }\end{array}$ \\
\hline Leptolophus & nouleti & (reconstruction) & 23.4 & 69.5 & 33.7 & -39 & Remy 1998: pl. 5 \\
\hline $\begin{array}{l}\text { Pliolophus } \\
\text { Miohippus } \\
\text { Miohippus } \\
\text { Parahippus } \\
\text { Merychippus } \\
\text { Pliohippus } \\
\text { Hipparion } \\
\text { Equus }\end{array}$ & $\begin{array}{l}\text { vulpiceps } \\
\text { meteulophus } \\
\text { equiceps } \\
\text { nebrascensis } \\
\text { sejunctus } \\
\text { lullianus } \\
\text { dolichops } \\
\text { ferus }\end{array}$ & $\begin{array}{l}\text { NHML M10657 } \\
\text { AMNH } 1210 \\
\text { AMNH } 7261 \\
\text { AMNH } 13770 \\
\text { AMNH } 8291 \\
\text { AMNH } 17225 \\
\text { AMNH } 10832 \\
\text { current }\end{array}$ & $\begin{array}{l}22.9 \\
43.0 \\
45.9 \\
76.5 \\
72.7 \\
66.6 \\
75.3 \\
66.5\end{array}$ & $\begin{array}{r}36.1 \\
91.1 \\
121.0 \\
184.0 \\
181.0 \\
189.0 \\
236.0 \\
220.0\end{array}$ & $\begin{array}{l}63.4 \\
47.2 \\
37.9 \\
41.6 \\
40.2 \\
35.2 \\
31.9 \\
30.2\end{array}$ & $\begin{array}{r}-52 \\
-25 \\
-23 \\
-17 \\
-12 \\
-5 \\
-4 \\
0\end{array}$ & $\begin{array}{l}\text { Simpson 1952: fig. } 1 \mathrm{~b} \\
\text { Osborn 1918: fig. } 30 \\
\text { Osborn 1918: fig. } 37 \\
\text { Osborn 1918: pl. } 7 \\
\text { Osborn 1918: pl. } 20 \\
\text { Osborn 1918: pl. } 27 \\
\text { Osborn 1918: fig. } 145 \\
\text { original }\end{array}$ \\
\hline
\end{tabular}

APPENDIX 20. - Upper (A) and lower (B) DPC lengths (in $\mathrm{mm}$ ) in various Equoidea. Bold, specific ranges; APSO, Association paléontologique du Sud-Ouest, Toulouse; (1), estimate; (2), M/3 outline completed; (3), estimate; (4), supposed.

\begin{tabular}{|c|c|c|c|c|c|c|c|}
\hline Taxon & Specimen & $\mathrm{L}_{\mathrm{DPC}}$ & $L_{P 2-M 3}$ & $\%$ DPC & Mean & SD & $\mathbf{v}$ \\
\hline \multicolumn{8}{|l|}{ A } \\
\hline Hallensia matthesi & GMH 22-no number & 11.4 & 59.0 & 19.3 & - & - & - \\
\hline Pliolophus vulpiceps & NHML M10657 & 14.5 & 41.3 & 35.1 & - & - & - \\
\hline Hyracotherium leporinum & NHML 16336 & 16.1 & 43.4 & 37.1 & - & - & - \\
\hline Xenicohippus tapirinum & AMNH 55267 & 17.5 & 46.2 & 37.9 & - & - & - \\
\hline Propalaeotherium hassiacum & $\begin{array}{l}\text { GMH 14-2175 } \\
\text { GMH 14-4174 } \\
\text { HLMD Me-54 } \\
\text { HLMD Me-71 } \\
\text { GMH 14-4007 } \\
\text { GMH 14-3238 } \\
\text { GMH 14-3081 } \\
\text { GMH 14-2645 } \\
\text { GMH 14-2338 } \\
\text { GMH 14-1311 }\end{array}$ & $\begin{array}{l}27.9 \\
25.2 \\
32.6 \\
26.9 \\
25.4 \\
29.8 \\
27.0 \\
33.4 \\
29.9 \\
26.9 \\
\end{array}$ & $\begin{array}{l}64.4 \\
70.1 \\
69.1 \\
66.8 \\
73.2 \\
66.9 \\
62.9 \\
69.3 \\
72.6 \\
70.7 \\
\end{array}$ & $\begin{array}{l}43.3 \\
35.9 \\
47.2 \\
40.3 \\
34.7 \\
44.5 \\
42.9 \\
48.2 \\
41.2 \\
38.0 \\
\end{array}$ & $\begin{array}{l}- \\
- \\
- \\
- \\
- \\
- \\
- \\
- \\
- \\
41.6\end{array}$ & $\begin{array}{l}- \\
- \\
- \\
- \\
- \\
- \\
- \\
- \\
- \\
4.497\end{array}$ & $\begin{array}{l}- \\
- \\
- \\
- \\
- \\
- \\
- \\
- \\
- \\
10.8\end{array}$ \\
\hline Propalaeotherium isselanum & $\begin{array}{l}\text { MNHN EBA-508 } \\
\text { private coll. no nº } \\
\text { GMH } 36-36\end{array}$ & $\begin{array}{l}30 \\
24.0 \\
28.5\end{array}$ & $\begin{array}{l}71.8 \\
63.4 \\
68.1\end{array}$ & $\begin{array}{l}41.8 \\
37.9 \\
41.9\end{array}$ & $\begin{array}{l}- \\
- \\
40.5\end{array}$ & $\begin{array}{l}- \\
- \\
2.291\end{array}$ & $\begin{array}{l}- \\
- \\
5.7\end{array}$ \\
\hline Propalaeotherium voigti & GMH 37-135 & 18.2 & 56.4 & 32.3 & - & - & - \\
\hline Propalaeotherium cf. gaudryi Aumelas & AUM 168 & 21.0 & 62.0 & 33.9 & - & - & - \\
\hline Eurohippus parvulus messelensis & $\begin{array}{l}\text { HLMD Me-7582 } \\
\text { HLMD Me-87 } \\
\text { HLMD Me- } 4379\end{array}$ & $\begin{array}{l}20.6 \\
23.0 \\
17.5\end{array}$ & $\begin{array}{l}40.3 \\
48.5 \\
44.0\end{array}$ & $\begin{array}{l}51.3 \\
47.4 \\
39.8\end{array}$ & $\begin{array}{l}- \\
- \\
46.1\end{array}$ & $\begin{array}{l}- \\
- \\
5.844\end{array}$ & $\begin{array}{c}- \\
- \\
12.7\end{array}$ \\
\hline
\end{tabular}


APPENDIX 20. - Continuation

\begin{tabular}{|c|c|c|c|c|c|c|c|}
\hline Taxon & Specimen & $\mathrm{L}_{\mathrm{DPC}}$ & $\mathrm{L}_{\mathrm{P} 2-\mathrm{M} 3}$ & $\% \mathrm{DPC}$ & Mean & SD & $\mathbf{v}$ \\
\hline Pachynolophus livinierensis & FSL 3068 & 19.5 & 41.3 & 47.2 & - & - & - \\
\hline Pachynolophus cesserasicus & FSL 2977 & 29.9 & 55.1 & 54.3 & - & - & - \\
\hline Pachynolophus eulaliensis & $\begin{array}{l}\text { UM-SEL } 101 \\
\text { UM-SEL } 25 \\
\text { UM-SEL } 03 \\
\text { UM-SEL } 88\end{array}$ & $\begin{array}{l}15.9 \\
18.3 \\
17.6 \\
16.0\end{array}$ & $\begin{array}{l}40.3 \\
34.9 \\
39.2 \\
40.0\end{array}$ & $\begin{array}{l}39.5 \\
52.4 \\
44.9 \\
40.0\end{array}$ & $\begin{array}{l}- \\
- \\
- \\
44.2\end{array}$ & $\begin{array}{l}- \\
- \\
- \\
6.013\end{array}$ & $\begin{array}{l}- \\
- \\
- \\
13.6\end{array}$ \\
\hline Pachynolophus ruscassierensis n. sp. & AUM 231 & 16.1 & 51.3 & 31.4 & - & - & - \\
\hline Lophiotherium cervulum & $\begin{array}{l}\text { FSL } 5909 \\
\text { FSL } 5910 \\
\end{array}$ & $\begin{array}{l}26.0 \\
27.2\end{array}$ & $\begin{array}{l}38.8 \\
41.6 \\
\end{array}$ & $\begin{array}{l}67.0 \\
65.4\end{array}$ & $-\overline{66.2}$ & $\begin{array}{l}- \\
-\end{array}$ & $\begin{array}{l}- \\
-\end{array}$ \\
\hline Metanchilophus dumasi & $\begin{array}{l}\text { UM } 5652 \\
\text { FSL } 6522\end{array}$ & $\begin{array}{l}35.0 \\
34.5\end{array}$ & $\begin{array}{l}66.5 \\
66.0\end{array}$ & $\begin{array}{l}52.6 \\
52.3\end{array}$ & - & - & - \\
\hline Metanchilophus castrensis & MHNT 2010.0.6 & 20.4 & 54.9 & 37.2 & - & - & - \\
\hline \multicolumn{8}{|l|}{ B } \\
\hline Pliolophus vulpiceps & $\begin{array}{l}\text { NHML M10657 } \\
\text { NHML } 44115\end{array}$ & $\begin{array}{l}17.0 \\
15.1\end{array}$ & $\begin{array}{l}47.6 \\
45.5\end{array}$ & $\begin{array}{l}35.7 \\
33.2\end{array}$ & $\overline{34.5}$ & - & $\begin{array}{l}- \\
-\end{array}$ \\
\hline Propalaeotherium gaudryi & UCMP 64904 & 23.0 & 73.0 & 31.5 & - & - & - \\
\hline Propalaeotherium hassiacum & $\begin{array}{l}\text { HLMD Me 54b } \\
\text { GMH 14-0341 } \\
\text { GMH 14-0515 } \\
\text { GMH 14-0533 } \\
\text { GMH 14-0681 } \\
\text { GMH 14-1053 } \\
\text { GMH 14-1379 } \\
\text { GMH 14-1395 } \\
\text { GMH 14-1675 } \\
\text { GMH 14-2254 } \\
\text { GMH 14-2933 } \\
\text { GMH 14-4304 } \\
\text { GMH 14-4619 } \\
\text { GMH 18-196 } \\
\text { GMH 50-1 }\end{array}$ & $\begin{array}{l}35.5 \\
23.0 \\
37.0 \\
28.0 \\
31.0 \\
26.0 \\
37.0 \\
32.9 \\
31.0 \\
37.0 \\
28.0 \\
40.0 \\
30.0 \\
32.0 \\
31.5 \\
\end{array}$ & $\begin{array}{l}75.3 \\
67.0 \\
80.0 \\
68.0 \\
81.0 \\
69.7 \\
74.0 \\
80.2 \\
74.0 \\
70.5 \\
80.0 \\
86.0 \\
75.0 \\
76.0 \\
72.0 \\
\end{array}$ & $\begin{array}{l}47.2 \\
34.3 \\
46.3 \\
41.2 \\
38.3 \\
37.3 \\
50.0 \\
41.1 \\
41.9 \\
52.5 \\
35.0 \\
46.5 \\
40.0 \\
42.1 \\
43.8 \\
\end{array}$ & $\begin{array}{l}- \\
- \\
- \\
- \\
- \\
- \\
- \\
- \\
- \\
- \\
- \\
- \\
- \\
- \\
42.5\end{array}$ & $\begin{array}{l}- \\
- \\
- \\
- \\
- \\
- \\
- \\
- \\
- \\
- \\
- \\
- \\
- \\
- \\
5.267\end{array}$ & $\begin{array}{l}- \\
- \\
- \\
- \\
- \\
- \\
- \\
- \\
- \\
- \\
- \\
- \\
- \\
- \\
12.4\end{array}$ \\
\hline Propalaeotherium voigti & GMH 14-0180 & 29.0 & 63.5 & 45.7 & - & - & - \\
\hline Propalaeotherium "isselanum" & $\begin{array}{l}\text { GMH 37-0066 } \\
\text { GMH 36-0281 } \\
\text { GMH 36-0092 }\end{array}$ & $\begin{array}{l}31.0 \\
31.5 \\
35.5\end{array}$ & $\begin{array}{l}69.0 \\
76.0 \\
84.0\end{array}$ & $\begin{array}{l}44.9 \\
41.4 \\
42.3 \\
\end{array}$ & $\begin{array}{l}- \\
\overline{42.9}\end{array}$ & $\begin{array}{l}- \\
- \\
4.620\end{array}$ & $\begin{array}{l}- \\
- \\
10.8\end{array}$ \\
\hline Eurohippus parvulus & $\begin{array}{l}\text { GMH 35-438 } \\
\text { GMH 37-161a }\end{array}$ & $\begin{array}{l}27.5 \\
30.0 \\
\end{array}$ & $\begin{array}{l}60.5 \\
59.5\end{array}$ & $\begin{array}{l}45.5 \\
50.4\end{array}$ & - & $\begin{array}{l}- \\
-\end{array}$ & $\begin{array}{l}- \\
-\end{array}$ \\
\hline Pachynolophus eulaliensis & UM-SEL 43 & 15.4 & 44.3 & 34.8 & - & - & - \\
\hline Pachynolophus cf. eulaliensis & APSO.2007 SP4-02 & 20.0 & 43.0 & 46.5 & - & - & - \\
\hline Pachynolophus sp. Mas de Piquet & UM unpublished & 22.0 & 46.7 & 47.1 & - & - & - \\
\hline Pachynolophus duvali & MNHN CGR-82 & $25.5(1)$ & $48.3(2)$ & 53.0 & - & - & - \\
\hline Pachynolophus livinierensis & NMB Liv-21 & 22.5 & 46.7 & 48.2 & - & - & - \\
\hline Pachynolophus ruscassierensis n. sp. & $\begin{array}{l}\text { AUM } 161 \text { (3) } \\
\text { AUM } 167\end{array}$ & $\begin{array}{l}23.0 \\
32.0\end{array}$ & $\begin{array}{l}56.5 \\
60(4)\end{array}$ & $\begin{array}{l}40.7 \\
53.3\end{array}$ & $\overline{47.2}$ & - & - \\
\hline Metanchilophus castrensis & NMB Cst-172 & 30.2 & 53.6 & 56.3 & - & - & - \\
\hline Metanchilophus dumasi & UM-F1 77 & 43.5 & 69.8 & 62.3 & - & - & - \\
\hline Lophiotherium cervulum & FSL 5916 & 33.6 & 45.7 & 73.6 & - & - & - \\
\hline
\end{tabular}


APPENDIX 21. - Upper cheek teeth surfaces (in $\mathrm{mm}^{2}$ ) of the Pachynolophus from Aumelas and comparisons with some other species. Bold, variation ranges. Pachynolophus zambranensis was not considered, since its M3/ is unknown. (1), Estimation of relative surface of the P/ area in Pachynolophus sp. from Aumelas: $\mathrm{SP}_{(1586)} / \mathrm{SM}_{(199)}$ : $185.2 / 482.2=38.4$; from means: $192.7 / 482.2=39.9$; with only AUM 199, assuming a P2/ surface identical to that of AUM 1586: $(45.4+68.7+86.3) / 482.2=41.6$.

\begin{tabular}{|c|c|c|c|c|c|c|c|c|c|c|c|c|c|}
\hline \multirow[b]{2}{*}{ specimens } & \multicolumn{6}{|c|}{ surfaces } & \multicolumn{3}{|c|}{ aggregate measures } & \multicolumn{4}{|c|}{ ratios } \\
\hline & P2/ & P3/ & P4/ & M1/ & M2/ & M3/ & $\mathrm{S}_{\mathrm{P} 2-\mathrm{M} 3}$ & $\mathrm{~S}_{\mathrm{P2}-\mathrm{P} 4}$ & $\mathrm{~S}_{\mathrm{M} 1-\mathrm{M} 3}$ & $\mathrm{~S}_{\mathrm{M} 3} / \mathrm{S}_{\mathrm{M} 1}$ & $\mathrm{~S}_{\mathrm{P}} / \mathrm{S}_{\mathrm{M}}$ & $\mathrm{S}_{\mathrm{P} 4} / \mathrm{S}_{\mathrm{M} 3}$ & $\mathrm{~S}_{\mathrm{P} 4} / \mathrm{S}_{\mathrm{M}}$ \\
\hline \multicolumn{14}{|c|}{ Pachynolophus ruscassierensis $\mathrm{n}$. sp. } \\
\hline $\mathrm{N}$ & 2 & 4 & 8 & 11 & 10 & 4 & - & - & - & - & - & - & - \\
\hline mean & 29.5 & 57.9 & 64.2 & 93.0 & 107.3 & 108.5 & 460.4 & 151.6 & 308.8 & 116.7 & 49.1 & 59.1 & 20.8 \\
\hline $\begin{array}{l}\text { standard } \\
\text { deviation }\end{array}$ & - & 3.823 & 10.903 & 13.545 & 21.720 & 14.272 & - & - & - & - & - & - & - \\
\hline $\begin{array}{l}\text { coeff. of } \\
\text { variation }\end{array}$ & - & 6.6 & 17.0 & 14.6 & 20.2 & 13.1 & - & - & - & - & - & - & - \\
\hline AUM 70 & - & 62.8 & - & - & - & - & - & - & - & - & - & - & - \\
\hline AUM 138 & - & - & 72.3 & 101.5 & - & - & - & - & - & - & - & - & - \\
\hline AUM 176 & - & - & - & 79.7 & - & - & - & - & - & - & - & - & - \\
\hline AUM 187 & - & - & - & 85.6 & - & - & - & - & - & - & - & - & - \\
\hline AUM 191 & - & - & - & - & - & 98.9 & - & - & - & - & - & - & - \\
\hline AUM 194 & - & - & - & 98.4 & - & - & - & - & - & - & - & - & - \\
\hline AUM 231 & 29.5 & 54.3 & 65.0 & 96.7 & 115.7 & 123.4 & 484.6 & 148.8 & 335.8 & 127.6 & 44.3 & 52.7 & 19.4 \\
\hline AUM 1544 & - & - & 61.2 & 98.4 & 116.8 & 117.9 & - & - & 333.0 & 119.9 & - & 51.9 & 18.4 \\
\hline AUM 1545 & - & - & - & 72.9 & 72.6 & - & - & - & - & - & - & - & - \\
\hline AUM 1546 & - & - & - & 79.5 & 80.1 & - & - & - & - & - & - & - & - \\
\hline AUM 1552 & 29.5 & 58.8 & 77.9 & 120.0 & 145.0 & - & - & - & - & - & - & - & - \\
\hline AUM 1553 & - & 55.5 & 77.7 & 103.3 & 124.0 & - & - & - & - & - & - & - & - \\
\hline AUM 1554 & - & - & 56.4 & 86.9 & 108.9 & - & - & - & - & - & - & - & - \\
\hline AUM 1555 & - & - & - & - & 118.6 & - & - & - & - & - & - & - & - \\
\hline AUM 1563 & - & - & - & - & 91.4 & 94.0 & - & - & - & - & - & - & - \\
\hline AUM 1565 & - & - & - & - & 99.7 & - & - & - & - & - & - & - & - \\
\hline AUM 1566 & - & - & 51.0 & - & - & - & - & - & - & - & - & - & - \\
\hline AUM 1567 & - & - & 51.9 & - & - & - & - & - & - & - & - & - & - \\
\hline \multicolumn{14}{|c|}{ Pachynolophus sp. from Aumelas } \\
\hline mean (1) & 45.4 & 66.0 & 81.3 & 132.4 & 175.1 & 174.7 & 674.9 & 192.7 & 482.2 & - & $38.4-41.6$ & - & - \\
\hline AUM 199 & - & 68.7 & 86.3 & 132.4 & 175.1 & 174.7 & - & - & 482.2 & 131.9 & - & 49.4 & 17.9 \\
\hline AUM 1586 & 45.4 & 63.4 & 76.4 & - & - & - & - & 185.2 & - & - & - & - & - \\
\hline \multicolumn{14}{|c|}{ Pachynolophus duvali } \\
\hline MCZH 5464 & 23.0 & 40.5 & 55.5 & 78.6 & 87.3 & 90.3 & 375.2 & 119.1 & 256.1 & 114.9 & 46.5 & 61.5 & 21.7 \\
\hline \multicolumn{14}{|c|}{ Pachynolophus eulaliensis } \\
\hline $\mathrm{N}$ & 2.0 & 3.0 & 3.0 & 3.0 & 3.0 & 3.0 & - & - & - & - & - & - & - \\
\hline mean & 18.8 & 29.6 & 39.7 & 53.3 & 68.0 & 63.2 & 272.5 & 88.1 & 184.4 & 118.6 & 47.8 & 62.9 & 21.5 \\
\hline $\begin{array}{l}\text { standard } \\
\text { deviation }\end{array}$ & 0.354 & 6.444 & 6.953 & 11.228 & 10.202 & 10.579 & - & - & - & - & - & - & - \\
\hline $\begin{array}{l}\text { coeff. of } \\
\text { variation }\end{array}$ & 1.9 & 21.7 & 17.5 & 21.1 & 15.0 & 16.8 & - & - & - & - & - & - & - \\
\hline UM-SEL 10 & 18.5 & 37.0 & 47.0 & 63.5 & 79.0 & 73.0 & 318.0 & 102.5 & 215.5 & 115.0 & 47.6 & 64.4 & 21.8 \\
\hline UM-SEL $25 \mathrm{~g}$ & - & 26.9 & 33.2 & 41.3 & 58.9 & 52.0 & - & - & 152.1 & 126.0 & - & 63.8 & 21.8 \\
\hline UM-SEL 88 & 19.0 & 25.0 & 39.0 & 55.0 & 66.0 & 64.5 & 268.5 & 83.0 & 185.5 & 117.3 & 44.7 & 60.5 & 21.0 \\
\hline \multicolumn{14}{|c|}{ Pachynolophus boixedatensis } \\
\hline ICP 2059 & - & - & 56.9 & 79.4 & 100.0 & 107.6 & - & - & 287.0 & 135.5 & - & 52.8 & 19.8 \\
\hline \multicolumn{14}{|c|}{ Pachynolophus molipontensis } \\
\hline ICP 9100 & 15.6 & 37.9 & 56.9 & 88.8 & 115.7 & 119.5 & 434.4 & 110.5 & 324.0 & 134.6 & 34.1 & 47.6 & 17.6 \\
\hline \multicolumn{14}{|c|}{ Pachynolophus livinierensis } \\
\hline FSL 3068 & 18.0 & 31.1 & 41.0 & 58.1 & 76.1 & 85.1 & 309.5 & 90.1 & 219.3 & 146.5 & 41.1 & 48.2 & 18.7 \\
\hline \multicolumn{14}{|c|}{ Pachynolophus cesserasicus } \\
\hline FSL 2977 & 25.4 & 48.2 & 69.0 & 98.4 & 131.1 & 140.2 & 512.5 & 142.7 & 369.8 & 142.5 & 38.6 & 49.2 & 18.7 \\
\hline \multicolumn{14}{|c|}{ Pachynolophus bretovensis } \\
\hline UM-BRT 130 & - & - & 54.8 & 89.9 & 100.6 & 88.1 & - & - & 278.6 & 97.9 & - & 62.2 & 19.7 \\
\hline \multicolumn{14}{|c|}{ Pachynolophus garimondi } \\
\hline UM-F1 290 & - & 31.9 & 52.1 & 78.4 & 96.9 & 103.2 & - & - & 278.5 & 131.7 & - & 50.4 & 18.7 \\
\hline \multicolumn{14}{|c|}{ Pachynolophus lavocati } \\
\hline MNHN Qu-7371 & 23.1 & 36.5 & 53.0 & 85.0 & 107.1 & 108.7 & 413.4 & 112.6 & 300.8 & 127.9 & 37.4 & 48.7 & 17.6 \\
\hline
\end{tabular}


APPENDIX 22. - Comparisons between lower cheek teeth surfaces (in $\mathrm{mm}^{2}$ ) of the Pachynolophus species from Aumelas. Significance probabilities established from Student's t-test. From means (AUM 1615 is the only specimen of Pachynolophus sp. with a series P/4-M/3).

\begin{tabular}{|c|c|c|c|c|c|c|c|}
\hline & \multicolumn{6}{|c|}{ Surfaces $=\mathbf{L} \times \mathbf{W}_{\max }$} & \multirow[b]{2}{*}{$\mathrm{S}_{\mathrm{P} 4} / \mathrm{S}_{\mathrm{M}}$} \\
\hline & $\mathrm{P} / 2$ & $\mathbf{P} / 3$ & $\mathrm{P} / 4$ & M/1 & $M / 2$ & $M / 3$ & \\
\hline \multirow{6}{*}{$\begin{array}{l}\text { Pachynolophus ruscassierensis } \mathrm{n} . \mathrm{sp} \text {. } \\
\mathrm{N} \\
\text { mean } \\
\text { variation range } \\
\text { standard deviation } \\
\text { coeff. of variation } \\
\end{array}$} & - & - & - & - & - & - & - \\
\hline & 3 & 3 & 5 & 12 & 11 & 7 & - \\
\hline & 30.0 & 44.3 & 54.4 & 56.6 & 76.6 & 96.9 & 23.7 \\
\hline & $25.5-32.7$ & $38.2-50.5$ & $48.1-57.7$ & $48.1-69.4$ & $61.1-99.9$ & $83.1-117.0$ & - \\
\hline & 3.967 & 6.150 & 3.763 & 5.971 & 12.093 & 12.929 & - \\
\hline & 13.2 & 13.9 & 6.9 & 10.6 & 15.8 & 13.3 & - \\
\hline Pachynolophus sp. from Aumelas & - & - & - & - & - & - & - \\
\hline $\mathrm{N}$ & 1 & - & 2 & 4 & 8 & 9 & - \\
\hline mean & 25.5 & - & 59.5 & 76.7 & 99.2 & 150.8 & 18.2 \\
\hline variation range & - & - & $58.5-60.5$ & 73.0-79.4 & $94.0-105.3$ & $140.2-163.6$ & - \\
\hline standard deviation & - & - & 1.393 & 3.052 & 3.973 & 8.626 & - \\
\hline coeff. of variation & - & - & 2.3 & 4.0 & 4.0 & 5.7 & - \\
\hline AUM 1615 & - & - & 60.5 & 75.5 & 97.1 & 147.0 & 18.9 \\
\hline
\end{tabular}

Comparing Pachynolophus sp. vs Pachynolophus ruscassierensis n. sp.

\begin{tabular}{|c|c|c|c|c|c|c|c|}
\hline $\begin{array}{l}\text { degree of freedom } \\
\mathrm{t}(\mathrm{Pa} \text {. sp./ruscassierensis n. sp.) } \\
\text { signification }\end{array}$ & $\begin{array}{l}2 \\
-0.9954 \\
\text { NS }\end{array}$ & $\begin{array}{l}- \\
- \\
-\end{array}$ & $\begin{array}{l}5 \\
1.7659 \\
\text { NS }\end{array}$ & $\begin{array}{l}14 \\
6.3718 \\
99.9\end{array}$ & $\begin{array}{l}17 \\
5.0664 \\
99.9\end{array}$ & $\begin{array}{l}14 \\
10.0172 \\
99.9\end{array}$ & $\begin{array}{l}- \\
- \\
-\end{array}$ \\
\hline Ratio (Pa. sp./ruscassier) & 84.8 & - & 109.3 & 135.6 & 129.6 & 155.7 & - \\
\hline
\end{tabular}


APPENDIX 23. - Comparisons of upper cheek teeth measures (in $\mathrm{mm}$ ) of Lophiotherium sp. from Aumelas (see Table 5) with those of $L$. pygmaeum and L. siderolithicum. Bold, variation ranges. Significance probabilities established from Student's t-test.

\begin{tabular}{|c|c|c|c|c|c|c|c|c|c|c|c|c|}
\hline & \multicolumn{4}{|c|}{ M1/ } & \multicolumn{4}{|c|}{ M2/ } & \multicolumn{4}{|c|}{ M3/ } \\
\hline & $\mathbf{L}$ & $\mathbf{W}$ & D & d & $\mathbf{L}$ & W & D & d & $\mathbf{L}$ & $\mathbf{W}$ & D & d \\
\hline \multicolumn{13}{|c|}{ Lophiotherium pygmaeum from Lissieu and Egerkingen } \\
\hline $\mathrm{N}$ & 13 & 13 & 13 & 13 & 11 & 11 & 11 & 11 & 20 & 20 & 20 & 20 \\
\hline mean & 7.2 & 9.5 & 9.7 & 9.0 & 7.9 & 10.3 & 10.8 & 9.9 & 7.9 & 10.1 & 10.7 & 9.6 \\
\hline standard deviation & 0.386 & 0.519 & 0.632 & 0.640 & 0.462 & 0.552 & 0.597 & 0.489 & 0.423 & 0.607 & 0.553 & 0.515 \\
\hline coeff. of variation & 5.3 & 5.5 & 6.5 & 7.1 & 5.9 & 5.4 & 5.5 & 4.9 & 5.4 & 6.0 & 5.2 & 5.4 \\
\hline FSL 2287a & 7.5 & 9.4 & 9.9 & 9.3 & - & - & - & - & - & - & - & - \\
\hline FSL 2287b & - & - & - & - & 8.2 & 10.4 & 10.9 & 10.2 & - & - & - & - \\
\hline FSL 2287c & - & - & - & - & - & - & - & - & 8.8 & 10.7 & 11.3 & 10.8 \\
\hline NMB Eb-001 & 6.7 & 9.7 & 9.6 & 9.9 & 7.0 & 10.6 & 10.7 & 10.4 & 7.2 & 10.5 & 10.4 & 10.0 \\
\hline NMB Eb-002 & 6.8 & 8.9 & 9.2 & 8.9 & 7.9 & 9.6 & 10.8 & 9.4 & - & - & - & - \\
\hline NMB Eb-003 & - & - & - & - & 8.4 & 10.3 & 10.7 & 10.1 & 8.2 & 10.7 & 11.1 & 10.1 \\
\hline NMB Eb-004 & 7.7 & 10.3 & 10.5 & 9.8 & - & - & - & - & - & - & - & - \\
\hline NMB Eb-005 & 7.7 & 9.8 & 10.6 & 9.2 & - & - & - & - & - & - & - & - \\
\hline NMB Eb-007 & 7.6 & 9.7 & 10.0 & 8.7 & - & - & - & - & - & - & - & - \\
\hline NMB Eb-008 & - & - & - & - & 7.8 & 10.2 & 10.5 & 9.9 & 8.0 & 9.5 & 10.4 & 9.6 \\
\hline NMB Eb-011 & 6.6 & 8.9 & 8.6 & 7.7 & - & - & - & - & - & - & - & - \\
\hline NMB Eb-012 & 7.4 & 9.3 & 9.2 & 9.2 & 8.1 & 10.0 & 10.2 & 10.0 & 7.8 & 9.7 & 9.9 & 9.7 \\
\hline NMB Eb-015 & - & - & - & - & 7.3 & 9.8 & 10.1 & 9.5 & 7.5 & 9.1 & 9.7 & 8.8 \\
\hline NMB Eb-016 & 7.2 & 9.7 & 10.0 & 9.6 & 7.7 & 10.7 & 11.4 & 10.5 & 7.7 & 10.4 & 11.0 & 9.7 \\
\hline NMB Eb-031 & - & - & - & - & - & - & - & - & 8.3 & 10.5 & 10.8 & 9.5 \\
\hline NMB Eb-039a & 7.0 & 8.6 & 9.2 & 8.6 & - & - & - & - & - & - & - & - \\
\hline NMB Eb-045 & - & - & - & - & - & - & - & - & 7.4 & 9.3 & 10.3 & 9.0 \\
\hline NMB Eb-053 & - & - & - & - & - & - & - & - & 8.2 & 10.6 & 11.1 & 10.0 \\
\hline NMB Eb-059 & - & - & - & - & - & - & - & - & 8.0 & 10.5 & 10.8 & 9.9 \\
\hline NMB Eb-060 & - & - & - & - & - & - & - & - & 7.4 & 9.2 & 10.1 & 8.7 \\
\hline NMB Eb-063 & - & - & - & - & 7.7 & 10.2 & 10.6 & 9.3 & 7.9 & 10.7 & 10.8 & 9.2 \\
\hline NMB Eb-065 & - & - & - & - & - & - & - & - & 7.3 & 9.7 & 10.4 & 9.1 \\
\hline NMB Eb-073 & 7.3 & 9.4 & 10.1 & 8.5 & - & - & - & - & - & - & - & - \\
\hline NMB Eb-078 & - & - & - & - & - & - & - & - & 8.5 & 11.2 & 12.1 & 9.8 \\
\hline NMB Eb-244 & - & - & - & - & - & - & - & - & 8.1 & 10.0 & 11.2 & 9.8 \\
\hline NMB Eb-260a (dext) & 7.0 & 9.1 & 9.1 & 8.2 & 8.0 & 9.8 & 10.3 & 9.4 & - & - & - & - \\
\hline NMB Eb-282 & - & - & - & - & - & - & - & - & 8.2 & 9.6 & 10.3 & 9.1 \\
\hline NMB Eb-473 & - & - & - & - & - & - & - & - & 7.5 & 9.6 & 10.5 & 9.4 \\
\hline NMB Eb-539 & - & - & - & - & - & - & - & - & 7.8 & 10.2 & 10.6 & 10.0 \\
\hline NMB Eh-356 & 7.6 & 10.3 & 10.5 & 9.3 & 8.6 & 11.6 & 12.2 & 10.7 & 8.0 & 10.6 & 11.1 & 10.0 \\
\hline
\end{tabular}

Comparing Lophiotherium sp. from Aumelas vs Lophiotherium pygmaeum

\begin{tabular}{llllllllcccccccc}
\hline degree of freedom & 13 & 13 & 13 & 14 & 10 & - & - & 11 & 19 & 19 \\
t (AUM/pygmaeum) & -1.346 & -3.244 & -2.250 & -2.655 & -0.569 & - & - & -0.660 & 5.236 & -0.827 & 1.609 & -0.242 \\
signification & NS & -99 & -95 & -98 & NS & - & - & NS & 99.9 & NS & NS & NS \\
\hline ratio (AUM/pygmaeum) & 94.6 & 85.5 & 88.4 & 88.2 & 96.4 & - & - & 97.5 & 125.5 & 94.9 & 108.5 & 98.9 \\
\hline
\end{tabular}

\section{Lophiotherium siderolithicum from Mormont}

\begin{tabular}{|c|c|c|c|c|c|c|c|c|c|c|c|c|}
\hline $\begin{array}{l}\mathrm{N} \\
\text { mean } \\
\text { standard deviation } \\
\text { coeff. of variation }\end{array}$ & $\begin{array}{c}8 \\
6.8 \\
0.267 \\
4.0\end{array}$ & $\begin{array}{c}8 \\
9.0 \\
0.243 \\
2.7\end{array}$ & $\begin{array}{r}8 \\
9.0 \\
0.331 \\
3.7\end{array}$ & $\begin{array}{c}8 \\
8.5 \\
0.616 \\
7.3\end{array}$ & $\begin{array}{c}6 \\
7.7 \\
0.629 \\
8.2\end{array}$ & $\begin{array}{c}6 \\
10.2 \\
0.441 \\
4.3\end{array}$ & $\begin{array}{c}6 \\
10.4 \\
0.452 \\
4.3\end{array}$ & $\begin{array}{r}6 \\
9.6 \\
0.417 \\
4.3\end{array}$ & $\begin{array}{c}16 \\
7.5 \\
0.369 \\
4.9\end{array}$ & $\begin{array}{c}16 \\
9.6 \\
0.601 \\
6.2\end{array}$ & $\begin{array}{c}16 \\
10.2 \\
0.496 \\
4.9\end{array}$ & $\begin{array}{r}16 \\
9.3 \\
0.500 \\
5.4\end{array}$ \\
\hline LM 99/2283 & 6.8 & 9.2 & 9.4 & 8.6 & - & - & - & - & - & - & - & - \\
\hline LM 143/2289 & 6.8 & 8.7 & 9.1 & 8.2 & - & - & - & - & - & - & - & - \\
\hline LM 97/2282 & 6.4 & 9.0 & 8.9 & 8.3 & 7.2 & 9.5 & 10.1 & 8.9 & 7.3 & 9.5 & 10.2 & 9.3 \\
\hline LM 116/1652 & 6.5 & 9.1 & 9.1 & 8.5 & 7.4 & 9.9 & 9.9 & 9.4 & 7.4 & 9.7 & 10.4 & 9.2 \\
\hline LM 112/1652 & 7.3 & 9.3 & 9.2 & 9.3 & 8.4 & 10.8 & 10.5 & 10.0 & 7.7 & 10.2 & 10.4 & 9.5 \\
\hline NMB Mt-1144 & 6.8 & 9.3 & 9.3 & 9.3 & 7.2 & 10.2 & 10.1 & 9.7 & 7.8 & 10.3 & 10.9 & 9.6 \\
\hline NMB Mt-1145-47 & 6.7 & 8.7 & 8.4 & 8.0 & - & - & - & - & - & - & - & - \\
\hline LM 98/1646 & - & - & - & - & 8.6 & 10.2 & 11.1 & 10.0 & 7.7 & 9.9 & 10.7 & 9.6 \\
\hline LM189/2411 & - & - & - & - & - & - & - & - & 7.6 & 10.0 & 10.9 & 9.5 \\
\hline LM117/2411 & - & - & - & - & - & - & - & - & 6.7 & 8.8 & 9.7 & 9.0 \\
\hline LM120/2411 & - & - & - & - & - & - & - & - & 7.4 & 8.5 & 9.4 & 8.2 \\
\hline LM142/2411 & - & - & - & - & - & - & - & - & 7.6 & 10.1 & 10.5 & 9.6 \\
\hline LM205/2411 & - & - & - & - & - & - & - & - & 8.0 & 10.3 & 10.5 & 9.6 \\
\hline LM106/2411 & - & - & - & - & - & - & - & - & 6.8 & 8.4 & 9.2 & 8.7 \\
\hline NMB Mt-0020 & 6.7 & 8.9 & 8.7 & 7.5 & - & - & - & - & - & - & - & - \\
\hline NMB Mt-0023a & - & - & - & - & - & - & - & - & 7.6 & 9.7 & 10.3 & 9.6 \\
\hline NMB Mt-1035 & - & - & - & - & 7.4 & 10.4 & 10.7 & 9.7 & 7.6 & 9.9 & 10.3 & 10.2 \\
\hline NMB Mt-1038 & - & - & - & - & - & - & - & - & 7.2 & 9.4 & 9.7 & 8.6 \\
\hline Genève 371/92 & - & - & - & - & - & - & - & - & 7.9 & 10.0 & 10.4 & 9.4 \\
\hline LM 129/2411 & - & - & - & - & - & - & - & - & 7.1 & 9.6 & 10.1 & 8.8 \\
\hline
\end{tabular}




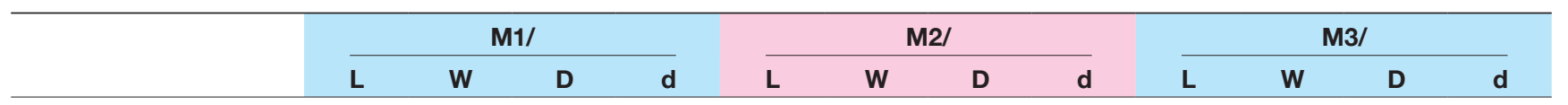

\begin{tabular}{lllllllllllll} 
Comparing Lophiotherium sp. from & Aumelas vs Lophiotherium siderolithicum \\
\hline degree of freedom & 9 & 9 & 9 & 10 & 7 & - & - & 8 & 17 & 17 & 17 & 17 \\
t (AUM/siderolithicum) & 0.569 & -3.224 & -1.398 & -1.468 & 0.558 & - & - & 0.503 & 5.485 & -0.085 & 2.820 & 0.505 \\
signification & NS & -98 & NS & NS & NS & - & - & NS & 99.9 & NS & 98 & NS \\
\hline $\begin{array}{l}\text { ratio (AUM/ } \\
\text { siderolithicum) }\end{array}$ & 101.6 & 88.9 & 94.4 & 93.8 & 104.6 & - & - & 102.6 & 133.1 & 99.5 & 113.9 & 103.0 \\
\hline
\end{tabular}

APPENDIX 24. - Comparisons of lower cheek teeth measures (in mm) of Lophiotherium sp. from Aumelas (see Table 5) with those of $L$. pygmaeum and L. siderolithicum. Bold, variation ranges. Significance probabilities established from Student's t-test.

\begin{tabular}{|c|c|c|c|c|c|c|c|c|c|c|c|c|c|c|c|c|}
\hline & \multicolumn{3}{|c|}{$\mathbf{P} / 3$} & \multicolumn{3}{|c|}{$\mathrm{P} / 4$} & \multicolumn{3}{|c|}{ M/1 } & \multicolumn{3}{|c|}{$M / 2$} & \multicolumn{4}{|c|}{$M / 3$} \\
\hline & $\mathbf{L}$ & W1 & W2 & $\mathbf{L}$ & W1 & W2 & $\mathbf{L}$ & W1 & W2 & $\mathbf{L}$ & W1 & W2 & $\mathbf{L}$ & W1 & W2 & W3 \\
\hline \multicolumn{17}{|c|}{ Lophiotherium pygmaeum from Egerkingen } \\
\hline $\mathrm{N}$ & 4 & 4 & 4 & 15 & 15 & 16 & 7 & 7 & 7 & 10 & 10 & 10 & 16 & 16 & 16 & 16 \\
\hline mean & 5.8 & 3.5 & 3.9 & 6.4 & 4.5 & 4.7 & 6.8 & 4.9 & 5.1 & 7.3 & 5.4 & 5.3 & 10.7 & 5.4 & 4.9 & 4.0 \\
\hline standard deviation & 0.206 & 0.238 & 0.238 & 0.324 & 0.399 & 0.225 & 0.256 & 0.227 & 0.177 & 0.327 & 0.291 & 0.263 & 0.687 & 0.292 & 0.269 & 0.316 \\
\hline coeff. of variation & 3.6 & 6.9 & 6.2 & 5.0 & 8.8 & 4.7 & 3.8 & 4.6 & 3.5 & 4.5 & 5.4 & 4.9 & 6.4 & 5.4 & 5.5 & 7.9 \\
\hline NMB Ec-011 & - & - & - & - & - & - & 7.3 & 4.5 & 5.2 & - & - & - & - & - & - & - \\
\hline NMB Ec-015 & - & - & - & - & - & 5.0 & 6.8 & 4.9 & 5.1 & 7.3 & 5.7 & 5.7 & - & - & - & - \\
\hline NMB Ec-016 & - & - & - & - & - & - & - & - & - & 7.2 & 5.0 & 5.0 & 9.0 & 4.6 & 4.4 & 3.2 \\
\hline NMB Ec-022 & - & - & - & - & - & - & - & - & - & - & - & - & 11.5 & 5.6 & 5.1 & 3.9 \\
\hline NMB Ec-031 & - & - & - & - & - & - & - & - & - & - & - & - & 11.3 & 5.6 & 4.9 & 3.9 \\
\hline NMB Ec-032 & - & - & - & - & - & - & - & - & - & - & - & - & 11.1 & 5.3 & 5.0 & 4.1 \\
\hline NMB Ec-035 & - & - & - & - & - & - & - & - & - & - & - & - & 11.7 & 5.7 & 5.0 & 4.7 \\
\hline NMB Ec-060 & - & - & - & - & - & - & - & - & - & 7.5 & 5.6 & 5.7 & 11.1 & 5.5 & 4.9 & 4.0 \\
\hline NMB Ec-089 & - & - & - & - & - & - & - & - & - & - & - & - & 10.4 & 5.1 & 4.8 & 3.9 \\
\hline NMB Ec-090 & - & - & - & - & - & - & - & - & - & - & - & - & 10.3 & 5.6 & 5.3 & 4.3 \\
\hline NMB Ec-125 & - & - & - & - & - & - & 6.8 & 5.0 & 4.8 & 7.5 & 5.4 & 5.2 & - & - & - & - \\
\hline NMB Ec-136 & - & - & - & - & - & - & - & - & - & - & - & - & 11.0 & 5.5 & 5.0 & 4.1 \\
\hline NMB Ec-139 & - & - & - & - & - & - & - & - & - & - & - & - & 10.5 & 5.2 & 4.8 & 4.0 \\
\hline NMB E & - & - & - & - & - & - & - & - & - & - & - & - & 10.4 & 5.7 & 5.5 & 4.4 \\
\hline NMB Ec-157 & - & - & - & - & - & - & - & - & - & - & - & - & 10.0 & 5.1 & 4.8 & 3.9 \\
\hline NMB Ec-206 & 5.9 & 3.8 & 4.0 & - & - & - & - & - & - & - & - & - & - & - & - & - \\
\hline NMB E & - & - & - & 6.4 & 4.4 & 5.0 & 6.7 & 4.9 & 5.1 & 7.7 & 5.5 & 5.3 & - & - & - & - \\
\hline NMB Ec-221 & - & - & - & 6.8 & 4.8 & 4.8 & - & - & - & - & - & - & - & - & - & - \\
\hline NMB Ec-236 & - & - & - & 6.8 & 4.6 & 4.5 & - & - & - & - & - & - & - & - & - & - \\
\hline NMB E & - & - & - & 6.0 & 3.6 & 4.4 & - & - & - & - & - & - & - & - & - & - \\
\hline NMB Ec-253 & - & - & - & 6.4 & 4.5 & 4.6 & - & - & - & - & - & - & - & - & - & - \\
\hline NMB Ec-286 & - & - & - & 6.7 & 4.5 & 4.6 & - & - & - & - & - & - & - & - & - & - \\
\hline NMB Ec-287 & - & - & - & 6.9 & 4.4 & 4.6 & - & - & - & - & - & - & - & - & - & - \\
\hline NMB Ec-307 & - & - & - & 6.4 & 4.4 & 4.9 & - & - & - & - & - & - & - & - & - & - \\
\hline NMB Ec-318 & 6.0 & 3.4 & 4.1 & - & - & - & - & - & - & - & - & - & - & - & - & - \\
\hline NMB Ec-331 & - & - & - & 6.2 & 5.0 & 5.1 & - & - & - & - & - & - & - & - & - & - \\
\hline NMB Ec-344 & - & - & - & 6.6 & & 5.0 & - & - & - & - & - & - & - & - & - & - \\
\hline NMB Ec-346 & - & - & - & 6.7 & 4.4 & 4.4 & - & - & - & - & - & - & - & - & - & - \\
\hline NMB Ec-348 & 5.6 & 3.3 & 3.7 & - & - & - & - & - & - & - & - & - & - & - & - & - \\
\hline NMB Ec-353 & - & - & - & - & - & - & - & - & - & 7.3 & 5.3 & 5.2 & 10.6 & 5.3 & 4.6 & 3.8 \\
\hline NMB Ec-390 & - & - & - & 6.4 & 4.4 & 4.9 & 6.5 & 5.2 & 5.3 & 7.3 & 5.8 & 5.7 & 11.3 & 5.5 & 5.1 & 4.1 \\
\hline NMB Ec-391 & - & - & - & 6.1 & 4.2 & 4.6 & 7.0 & 4.7 & 5.0 & 7.3 & 5.3 & 5.3 & 10.9 & 5.1 & 4.6 & 3.9 \\
\hline NMB Ed-367 & - & - & - & - & - & - & - & - & - & 7.0 & 5.2 & 5.2 & 10.0 & 5.4 & 4.9 & 4.0 \\
\hline NMB Ed-368 & 5.6 & 3.3 & 3.6 & 5.8 & 4.3 & 4.7 & 6.7 & 5.0 & 5.3 & 6.5 & 4.9 & 5.1 & - & - & - & - \\
\hline NMB Ed-382 & - & - & - & 6.2 & 5.3 & 4.8 & - & - & - & - & - & - & - & - & - & - \\
\hline
\end{tabular}

\section{Comparing Lophiotherium sp. from Aumelas vs Lophiotherium pygmaeum}

$\begin{array}{lllllllllllllllll}\text { degrees of freedom } & 3 & 3 & 3 & - & - & 15 & 10 & 9 & 9 & 11 & 10 & 10 & 16 & 16 & 15 & 15\end{array}$

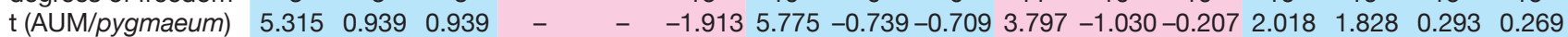
signification ratios (AUM/

pygmaeum)

98 NS NS -

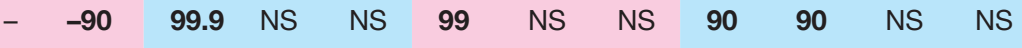

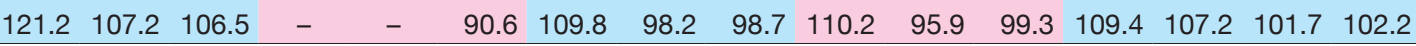




\begin{tabular}{|c|c|c|c|c|c|c|c|c|c|c|c|c|c|c|c|c|}
\hline & \multicolumn{3}{|c|}{$\mathrm{P} / 3$} & \multicolumn{3}{|c|}{$\mathrm{P} / 4$} & \multicolumn{3}{|c|}{ M/1 } & \multicolumn{3}{|c|}{$M / 2$} & \multicolumn{4}{|c|}{$M / 3$} \\
\hline & $\mathbf{L}$ & W1 & W2 & $\mathbf{L}$ & W1 & W2 & $\mathbf{L}$ & W1 & W2 & $\mathbf{L}$ & W1 & W2 & $\mathbf{L}$ & W1 & W2 & W3 \\
\hline \multicolumn{17}{|c|}{ Lophiotherium siderolithicum from Mormont-Eclepens } \\
\hline & 1 & 1 & 1 & 2 & 2 & 2 & 3 & 3 & 3 & 6 & 6 & 6 & 5 & 5 & 5 & 5 \\
\hline mean & 6.6 & 3.7 & 4.2 & 6.6 & 4.9 & 5.3 & 6.7 & 5.0 & 5.1 & 7.1 & 5.1 & 5.5 & 10.5 & 5.1 & 4.8 & 3.8 \\
\hline standard deviation & - & - & - & 0.018 & 0.204 & 0.176 & 0.297 & 0.188 & 0.057 & 0.420 & 0.352 & 0.274 & 0.820 & 0.292 & 0.230 & 0.205 \\
\hline coeff. of variation & - & - & - & 0.3 & 4.1 & 3.3 & 4.4 & 3.7 & 1.1 & 5.9 & 6.9 & 5.0 & 7.8 & 5.7 & 4.8 & 5.4 \\
\hline MGL-47364 & - & - & - & 6.6 & 5.1 & 5.4 & 7.0 & 5.2 & 5.2 & - & - & - & - & - & - & - \\
\hline NMB Mt-0011 & _ & _ & _- & - & - & - & - & - & - & 6.7 & 4.8 & 5.2 & _ & - & - & _- \\
\hline NMB Mt-0015 & - & - & - & - & - & - & - & - & - & 7.0 & 4.9 & 5.1 & - & - & - & - \\
\hline NMB Mt-0022 & - & - & - & - & - & - & - & - & - & - & - & - & 11.8 & 5.5 & 5.1 & 4.0 \\
\hline NMB Mt-0031 & - & - & - & - & - & - & 6.4 & 4.9 & 5.1 & - & - & - & - & - & - & - \\
\hline NMB Mt-0172 & - & - & - & - & - & - & - & - & - & 6.6 & 4.8 & 5.7 & - & - & - & _- \\
\hline NMB Mt-0186 & - & - & - & - & - & - & - & - & - & 7.4 & 5.7 & 5.8 & - & - & - & - \\
\hline NMB Mt-0188 & - & - & - & - & - & - & - & - & - & - & - & - & 10.1 & 5.2 & 4.6 & 3.8 \\
\hline NMB Mt-0191 & - & _- & _- & _- & - & - & _- & _- & _- & - & _- & - & 10.5 & 5.1 & 4.8 & 3.8 \\
\hline NMB Mt-1150 & - & - & - & - & - & - & - & - & - & - & - & - & 9.6 & 4.7 & 4.5 & 3.5 \\
\hline NMB Mt-1151 & - & - & - & - & - & - & - & - & _- & 7.7 & 5.3 & 5.4 & - & - & - & - \\
\hline NMB Mt-1152 & - & _- & _- & 6.6 & 4.8 & 5.2 & _- & _- & - & - & - & - & - & - & - & _- \\
\hline NMB Mt-1157 & - & - & - & - & - & - & - & - & - & 7.2 & 5.1 & 5.5 & - & - & - & - \\
\hline NMB Mt-1507 & - & - & - & - & - & - & - & _- & - & - & - & - & 10.3 & 5.0 & 4.8 & 4.0 \\
\hline NMB Mt-1509 & - & - & - & - & - & - & 6.7 & 4.9 & 5.1 & - & - & - & - & - & - & - \\
\hline NMB Mt-1510 & 6.6 & 3.7 & 4.2 & - & - & - & - & - & - & - & - & - & - & - & - & - \\
\hline
\end{tabular}

Comparing Lophiotherium sp. from Aumelas vs Lophiotherium siderolithicum

\begin{tabular}{llllllllllllllllll}
\hline $\begin{array}{l}\text { degrees of freedom } \\
\text { t(AUM/ }\end{array}$ & - & - & - & - & - & 1 & 6 & 5 & 5 & 7 & 6 & 6 & 5 & 5 & 4 & 4 \\
$\quad \begin{array}{l}\text { siderolithicum) } \\
\text { signification }\end{array}$ & - & - & - & - & - & -4.744 & 2.809 & -0.962 & -1.261 & 3.154 & 0.124 & -0.481 & 1.855 & 2.800 & 0.952 & 1.247 \\
& - & - & - & - & - & NS & 95 & NS & NS & 98 & NS & -90 & NS & 95 & NS & NS \\
\hline $\begin{array}{l}\text { ratios (AUM/ } \\
\text { siderolithicum) }\end{array}$ & 106.1 & 100.0 & 97.6 & - & - & 80.8 & 112.0 & 95.8 & 98.4 & 112.7 & 101.0 & 97.2 & 111.9 & 112.7 & 105.0 & 107.3 \\
\hline
\end{tabular}


APPENDIX 25. - Comparisons of lower cheek teeth measures of "Propachynolophus maldani" from Rouzilhac with Orolophus maldani and Pachynolophus ruscassierensis n. sp. (see Table 3) Data of Rouzilhac given by Godinot et al. 2018. Significance probabilities established from Student's t-test.

\begin{tabular}{|c|c|c|c|c|c|c|c|c|c|c|c|c|c|c|c|c|c|c|c|}
\hline & \multicolumn{2}{|c|}{$P / 2$} & \multicolumn{3}{|c|}{$P / 3$} & \multicolumn{3}{|c|}{$\mathrm{P} / 4$} & \multicolumn{3}{|c|}{ M/1 } & \multicolumn{3}{|c|}{$M / 2$} & \multicolumn{4}{|c|}{$M / 3$} & \multirow{2}{*}{$\begin{array}{c}\mathrm{L}_{\mathrm{M} 1-} \\
\mathrm{M} 3\end{array}$} \\
\hline & $\mathbf{L}$ & $W_{1}$ & $\mathbf{L}$ & $W_{1}$ & $W_{2}$ & $\mathbf{L}$ & $W_{1}$ & $W_{2}$ & $\mathbf{L}$ & $W_{1}$ & $W_{2}$ & $\mathbf{L}$ & $W_{1}$ & $W_{2}$ & $\mathbf{L}$ & $w_{1}$ & $W_{2}$ & $W_{3}$ & \\
\hline \multirow{5}{*}{$\begin{array}{l}\text { Orolophus maldani } \\
\mathrm{N} \\
\text { mean } \\
\text { standard deviation } \\
\text { coeff. of variation } \\
\end{array}$} & & & & & & & & & & & & & & & & & & & \\
\hline & - & - & - & - & - & 3 & 3 & 3 & 1 & - & 1 & 4 & 4 & 4 & 7 & 7 & 7 & 6 & 2 \\
\hline & & - & & - & & & & & 6.2 & - & 5.3 & & 5.9 & 5.8 & & 5.6 & 5.0 & 3.9 & 24.0 \\
\hline & & - & & & & 1.132 & 0.333 & 30.432 & $2-$ & - & - & 0.596 & 0.565 & 0.477 & 70.801 & 0.562 & 0.491 & 0.579 & 90.63 \\
\hline & - & - & - & - & - & 17.1 & 7.6 & 9.0 & - & - & - & 7.4 & 9.5 & 8.2 & 7.7 & 10.0 & 9.8 & 14.8 & 2.7 \\
\hline \multicolumn{20}{|l|}{ Grauves } \\
\hline & - & - & - & - & - & & & 5.0 & - & - & 5.3 & 7.7 & 5.9 & 5.7 & 10.2 & 5.6 & 4.9 & 4.0 & 24.4 \\
\hline & & - & & - & & & 4. & & - & - & & - & - & - & - & - & - & - & - \\
\hline & - & - & - & - & - & - & - & - & - & - & - & - & - & - & 10.7 & 5.6 & 4.8 & - & - \\
\hline & - & - & - & - & - & - & - & - & - & - & - & 8.0 & 5.8 & 5.9 & - & - & - & - & - \\
\hline & - & - & & - & - & - & - & - & - & - & - & - & - & - & 9.4 & & 4.4 & 3.0 & - \\
\hline MNHI & - & - & - & - & - & - & - & - & - & - & - & - & - & - & 9.9 & & 4.8 & 6 & - \\
\hline \multicolumn{20}{|l|}{ Cuis (ageian fauna) } \\
\hline & - & - & - & - & - & 5.8 & 4.1 & 4.3 & 6.2 & - & - & 7.6 & 5.3 & 5.3 & 10.2 & 5.2 & 5.0 & 4.1 & 23.5 \\
\hline & - & - & - & - & - & - & - & - & - & - & - & - & - & - & 10.9 & 6.1 & 5.5 & 4.4 & - \\
\hline MNHN A & - & - & - & - & - & - & - & - & - & - & - & 8.9 & 6.7 & 6.5 & 11 & & 5.9 & & - \\
\hline \multicolumn{20}{|c|}{ “Propachynolophus maldani” from Rouzilhac } \\
\hline & 3 & 3 & 7 & 7 & 5 & 12 & 12 & 12 & 14 & 13 & 12 & 12 & 13 & 11 & 11 & 12 & 12 & 11 & 9 \\
\hline & 6.2 & 3.3 & 7.5 & 4.1 & 4.5 & 7.7 & 5.1 & 5.3 & 8.9 & 5.8 & 6.0 & 10.1 & 6.9 & 6.6 & 14.6 & 6.7 & 5.8 & 4.9 & 33.8 \\
\hline & 0.503 & 0.436 & 0.251 & 0.522 & 0.130 & 0.584 & 0.42 & 0.326 & 0.677 & 0.416 & 0.37 & 0.617 & 0.397 & 0.363 & 0.749 & 0.339 & 0.291 & 0.239 & 1.2 \\
\hline coeff. o & 8.1 & 13.2 & 3.3 & 12.6 & 2.9 & 7.6 & 8.3 & 6.1 & 7.6 & 7.2 & 6.1 & 6.1 & 5.8 & 5.5 & 5.1 & 5.1 & 5.0 & 4.9 & 3.6 \\
\hline MNU & - & - & - & - & - & & 4. & & & & 5.6 & & & 6.4 & 13.7 & & 5.6 & 5.1 & 31.3 \\
\hline & - & - & - & - & - & & 5.2 & & & & 6.3 & & & .9 & & & & 5.0 & 34.3 \\
\hline & - & - & & - & - & - & - & - & - & - & - & 10.5 & 7.1 & 6.6 & 13.5 & & 5.8 & & - \\
\hline & & - & & & & & 5.1 & 5.3 & & 5.7 & 6.1 & 11. & & 7.1 & 13.9 & & 6.2 & .9 & 32.8 \\
\hline dex & 5.7 & 2.8 & & & 4.6 & 7.5 & 4.2 & 4.9 & 8.6 & 5.1 & 5.2 & 9.3 & 6.2 & 5.9 & 14.0 & 6.2 & 5.5 & 4.8 & 31.6 \\
\hline & - & - & - & - & - & - & - & - & - & - & - & - & - & - & 15.7 & 7.4 & 6.3 & 5.3 & - \\
\hline & - & - & & 4.4 & 4.7 & & 5.5 & 5.6 & & - & - & 10.2 & & 6.5 & & & & .7 & 34.5 \\
\hline & - & - & - & - & - & & 5 & & & & 6.4 & 10.2 & & 7.0 & 14.7 & 6.7 & 5.8 & 5.0 & 34.9 \\
\hline & - & - & - & - & - & & 4 & 5 & & & 6 & 9.3 & 6 & 6.4 & - & - & - & - & - \\
\hline & - & - & - & - & - & & 5. & 5. & & 5.2 & 5.7 & 10.0 & & 7.0 & - & 6.9 & 6.2 & - & - \\
\hline & & 3.5 & & & 4.4 & & 5.3 & & & & - & - & & - & - & - & - & - & - \\
\hline & - & - & - & - & - & - & - & - & & 5 & 6.0 & 10.7 & 6.2 & 6.5 & 15.3 & 6.5 & 5.7 & 4.9 & 34.9 \\
\hline & - & - & - & - & - & - & - & - & 9.7 & 5.6 & 6.1 & - & - & - & - & - & - & - & - \\
\hline & - & - & & 4.0 & 4.5 & 7.5 & 4.7 & 5.3 & 8.8 & 6.2 & 6. & - & - & - & - & - & - & - & - \\
\hline & 6.7 & 3.6 & & 4 & - & & 5.6 & 5.5 & & 6.1 & & 9.7 & 6.8 & 6.6 & 14.9 & 6.7 & 5.5 & 4.6 & 34.6 \\
\hline MNHN RZ-225 & - & - & 7.5 & 4.6 & - & 8.7 & 4.9 & 5.2 & 10.0 & 5.9 & 6.2 & 10.7 & 7.6 & - & 15.0 & 6.9 & 6.1 & 4.7 & 34.9 \\
\hline
\end{tabular}

Comparing "Propachynolophus maldani" from Rouzilhac vs Orolophus maldani

\begin{tabular}{|c|c|c|c|c|c|c|c|c|c|c|c|c|c|c|c|c|c|c|c|}
\hline $\begin{array}{l}\text { degree of freedom } \\
\text { t (“maldani” RZ / } \\
\text { maldani) }\end{array}$ & - & - & - & - & - & $\begin{array}{c}13 \\
3.732\end{array}$ & $\begin{array}{c}13 \\
8.301\end{array}$ & $\begin{array}{c}13 \\
4.814\end{array}$ & $\begin{array}{c}13 \\
3.879\end{array}$ & - & $\begin{array}{c}11 \\
1.881\end{array}$ & $\begin{array}{c}14 \\
12.891\end{array}$ & $\begin{array}{c}15 \\
6.564\end{array}$ & $\begin{array}{c}13 \\
5.875\end{array}$ & $\begin{array}{c}16 \\
17.757\end{array}$ & $\begin{array}{c}17 \\
6.656\end{array}$ & $\begin{array}{c}17 \\
5.934\end{array}$ & $\begin{array}{c}16 \\
5.982\end{array}$ & $\begin{array}{c}8 \\
6.658\end{array}$ \\
\hline signification & - & - & - & - & - & 99 & 99.9 & 99.9 & 99 & - & 90 & 99.9 & 99.9 & 99.9 & 99.9 & 99.9 & 99.9 & 99.9 & 99.9 \\
\hline $\begin{array}{l}\text { ratio (“maldani” RZ / } \\
\text { maldani) }\end{array}$ & - & - & - & - & - & 116.1 & 116.0 & 111.0 & 144.4 & - & 114.0 & 125.5 & 116.0 & 113.5 & 140.3 & 118.8 & 116.4 & 126.2 & 143.6 \\
\hline
\end{tabular}

\section{Comparing "Propachynolophus maldani" from Rouzilhac vs Pachynolophus ruscassierensis n. sp.}

\begin{tabular}{lllllllllllllllllllll}
\hline degree of freedom & 4 & 4 & 8 & 8 & 6 & 15 & 15 & 15 & 24 & 23 & 21 & 21 & 22 & 20 & 16 & 19 & 18 & 16 & 9
\end{tabular}

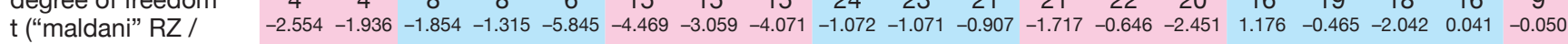
ruscassier)

$\begin{array}{llllllllllllllllllllll}\text { signification } & -90 & N S & N S & N S & -99 & -99.9 & -99 & -99.9 & N S & N S & N S & N S & N S & -95 & \text { NS } & \text { NS } & -90 & \text { NS } & \text { NS }\end{array}$

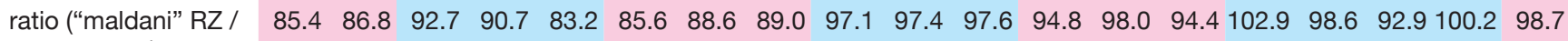
ruscassier) 